\title{
HOW TO KNOW
}

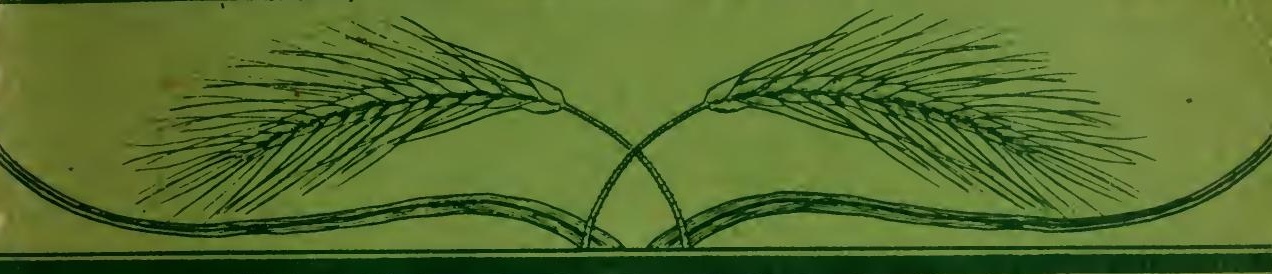

a

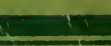

THE

GRASSES

George M. Gray Museum
Marine Biological Laboratory

R. W. POH Hods Massachusetts 025
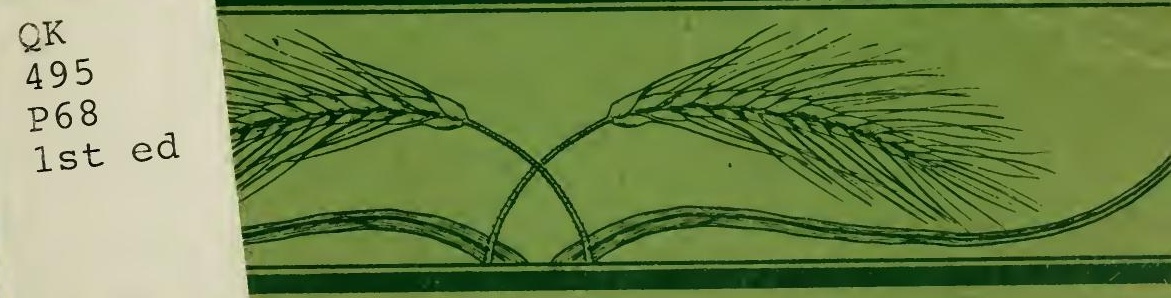

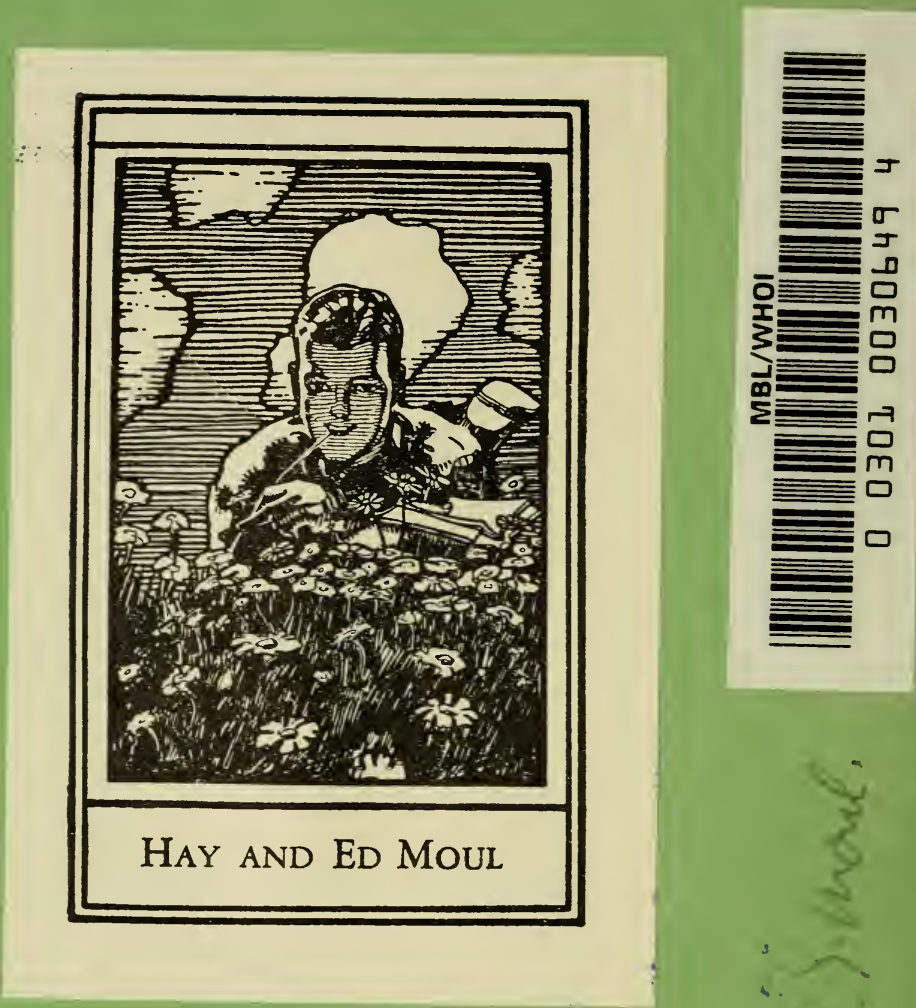


\section{How To Know \\ THE GRASSES}

George M. Gray Museum

Marine Biological Laboratory

Pictured-Keys for determining the common and im 02543 portant American grasses with suggestions and aids for their study.

By

RICHARD W. POHL

Associate Professor Botany

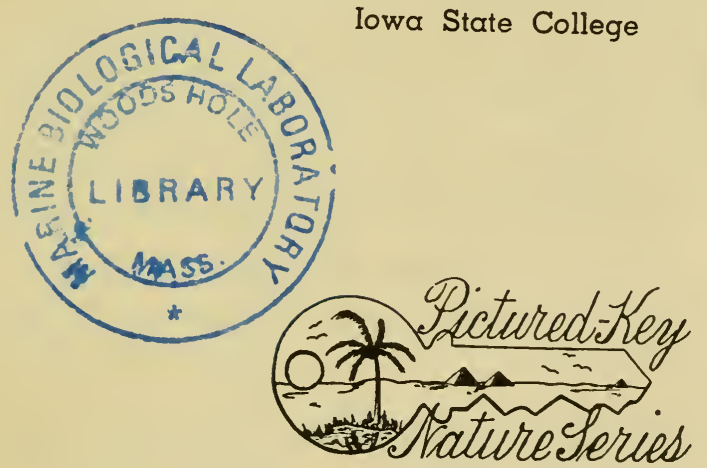

WM. C. BROWN COMPANY

Publishers

DUBUQUE, IOWA 
Copyright 1954

by

H. E. Jaques

\section{THE PICTURED-KEY NATURE SERIES}

"How to Know the Insects," Jaques, 1947

"Living Things-How to Know Them," Jaques, 1946

"How to Know the Trees," Jaques, 1946

"Plant Families-How to Know Them," Jaques, 1948

"Plants We Eat and Wear," Jaques, 1943

"How to Know the Spring Flowers," Cuthbert, 1943, 1949

"How to Know the Mosses," Conard, 1944

"How to Know the Land Birds," Jaques, 1947

"How to Know the Fall Flowers," Cuthbert, 1948

"How to Know the Immature Insects," Chu, 1949

"How to Know the Protozoa," Jahn, 1949

"How to Know the Mammals," Booth, 1949

"How to Know the Beetles," Jaques, 1951

"How to Know the Spiders," Kaston, 1952

"How to Know the Grasses," Pohl, 1954

In Both Spiral and Cloth Binding

Other Subjects in Preparation 


\section{INTRODUCTION}

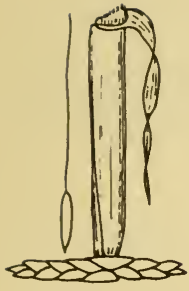

$\mathrm{N}$ the main text of this book, 293 kinds of grasses are illustrated and keyed out. These are the commonest and most important species of American grasses -those that the beginner is most apt to meet, and those of importance in farming, gardening, weed control, range and pasture management. In addition to those keyed and illustrated, 91 others are mentioned in connection with closely related species, and their distinguishing features are pointed out.

The illustrations are all new and have been made from actual specimens. Most of the spikelet drawings were made by camera lucida or projection methods and hence represent individual spikelets, not averages. Drawings of small structures, such as spikelets or their parts, bear measuring scales. These are used to indicate the size of the structures, exactly like the scales used in maps. The scales are marked off into spaces representing millimeters, and the total length of the scale in millimeters is marked. In a few drawings the scale is designed for one particular object, in which case an arrow points to the intended object.

The maps included in the species drawings represent approximate ranges of the species. Due to lack of exact information, particularly about the arctic and tropical extensions of these ranges, the maps cannot be entirely accurate, but will serve to give a general idea of the geographic area in which a species may occur in favorable habitats. The maps are based upon published records, herbarium spec:mens, and the author's personal information.

Drawings marked with the letter B are the work of Mrs. J. Bardach of Iowa State Teachers College, whose assistance is gratefully acknowledged. All others are the work of the author.

For most species, the period of flowering and fruiting is indicated. These dates cover the entire period during which fully developed and intact inflorescences can be found on the plants. Since grass flowers are rarely used in identification, actual flowering dates are not given.

Many persons have aided in the production of this little book. First of all, the author wishes to thank his wife and family, for the gift of time, which allowed its completion. The facilities of Iowa State 
College, in particular the excellent grass herbarium, were invaluable. Dr. H. E. Jaques, the editor of the Pictured-Key Nature Series, has been constantly helpful. The keys have been tested repeatedly by the author's students, and for their cooperation he extends his heartfelt thanks.

Âmes, Iowa

October, 1953

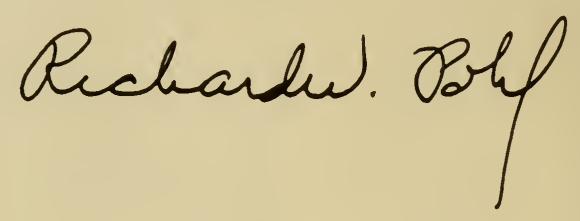

The Grass Family ranks near the top of the plant kingdom in the number of species it contains. No other group of plants figures so prominently in furnishing us with food. To know a good number of grasses is a cultural obligation as well as a source of personal satisfaction.

Dr. Pohl's keys and illustrations are the result of years of study and work with these interesting plants. His book is well worthy of a place in the Pictured-Key Nature Series and in the library of every plant lover.

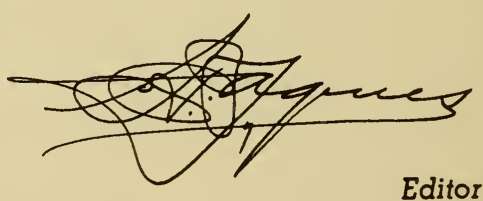




\section{CONTENTS}

Page

Introduction

What Is a Grass............................... I

Key to Grasses, Sedges and Rushes.................. 2

What Do Grasses Look Like...................... 3

How to Collect and Study Grasses.................. 7

How to Recognize the Tribes of Grasses................. 10

Some Useful Books on Grasses....................... 13

Pictured-Keys to Common American Grasses............... 15

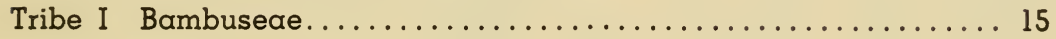

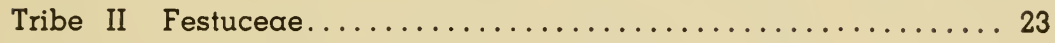

Tribe III Hordeae................................ 85

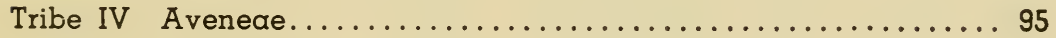

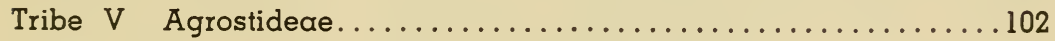

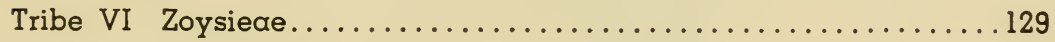

Tribe VII Chlorideae.....................................

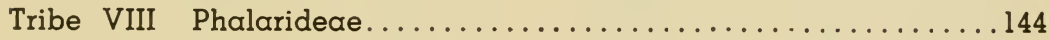

Tribe IX Oryzeae............................... 146

Tribe $\mathrm{X}$ Zizanieae................................ 147

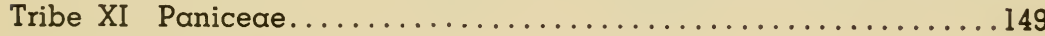

Tribe XII Andropogoneae............................ 176

Tribe XIII Tripsaceae............................ 184

Index and Pictured-Glossary.......................... 186
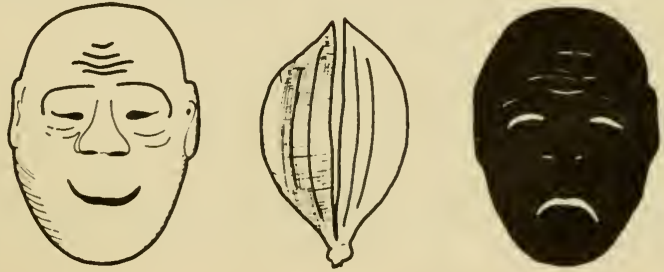

LIGHT ON A "GLUMEY" SUBJECT 


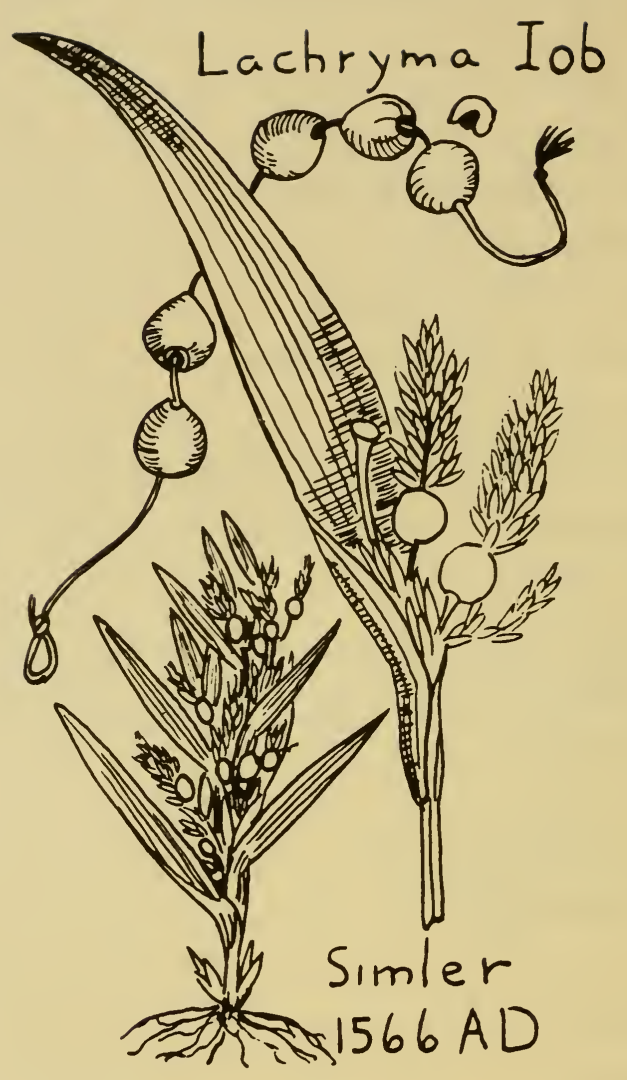




\section{WHAT IS A GRASS?}

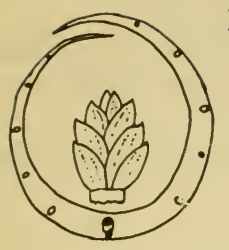

$F$ all the world's flowering plants, the grasses are undoubtedly the most important to man. They contribute tremendously to the earth's green mantle of vegetation; they are the source of the principal foods of man and his domestic animals. Without the grasses, agriculture would be virtually impossible: grain, sugar, syrup, spice, paper, perfume, pasture, oil and timber, and a thousand other items of daily use are products of various grasses. They hold the hills, plains and mountains against the destructive erosive forces of wind and water. In the end, they form the sod that covers the sleeping dead.

Despite the fact that the grasses are so important to us, we usually know little about them. Why? Because we think that "All grasses are alike," or "They are too hard to tell apart." But neither statement is true. There are over five thousand "kinds" or species of grasses in the world and fourteen hundred of these are found in the United States alone. This book contains descriptions and pictures of over three hundred of the more common grasses of our country. While many are superficially similar, they all have good individual marks of recognition. Nobody would at a second glance, for example, confuse foxtail and corn, or quackgrass and oats, or Sudan grass and barley, yet these are all grasses, members of one natural family, the GRAMINE$\overline{A E}$, or grass family.

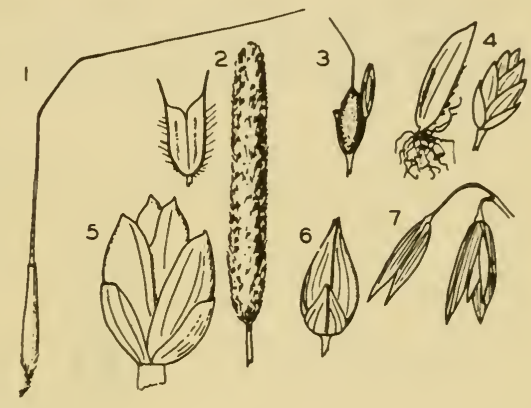

Grasses are easy to recognize. Here are some common ones. 1. Floret of porcupine grass (Stipa). 2. Spikelet and panicle of timothy (Phleum). 3. Branchlet with spikelets of Johnson grass (Sorghum). 4. Floret and spikelet of Kentucky bluegrass (Poa). 5. Spikelet of wheat (Triticum). 6. Spikelet of proso millet (Panicum). 7. Spikelets of oats (Avena).

\section{HOW TO RECOGNIZE THE GRASS FAMILY}

The grasses and their allies are all members of the great group of flowering plants which we call the MONOCOTYLEDONS. The members of this group are alike in having one seed leaf, parallel-veined leaves (with few exceptions), and stems in which the vascular bundles are scattered in the pith. Among the Monocotyledons, members of three families of plants have a "grasslike" appearance and may be confused. These are the grasses (Gramineae), the sedges (Cyperaceae), and the rushes (Juncaceae). $\AA$ little study of the following key and pictures will show how to separate them quickly and surely. 


\section{KEY TO GRASSES, SEDGES AND RUSHES}

la. Flowers with stiff, greenish or brownish, six-parted perianth (calyx and corolla); stamens 6 or 3; fruit a many-seeded capsule; leaves

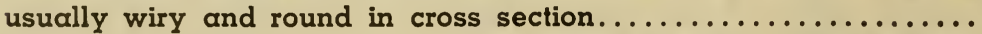

1b. Flowers without evident calyx or corolla, gathered into short scaly clusters (spikelets); stamens 3 ; fruit with a single seed.......2

2a. Leaves in 2 vertical rows or ranks; leaf sheaths usually split, with overlapping edges; stems usually round in cross section and hollow between the joints; each flower of the spikelet contained be-

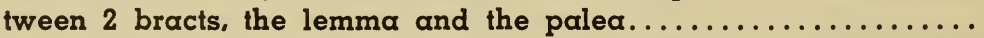
.GRASS FAMILY (GRAMINEAE)

2b. Leaves in 3 vertical rows or ranks; leaf sheaths tubular, not split; stems often triangular in cross section and solid between joints; each flower of the spikelet in the axil of a single bract, the glume ........................... FEDEE FAMILY (CYPERACEAE)

DIFFERENCES AMONG GRASSES, SEDGES, AND RUSHES

GRASS

SEDGE

RUSH

STEM AND LEAF
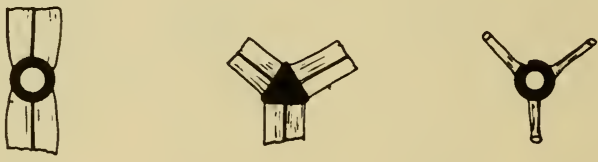

LEAF SHEATH
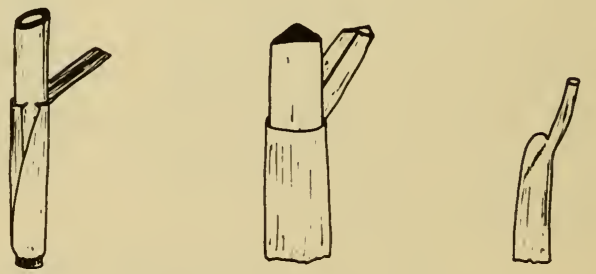

FLORET OR

FLOWER
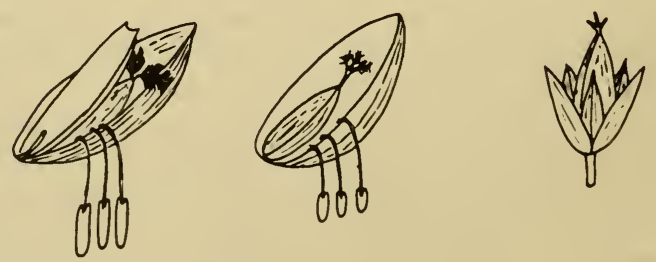

Figure 1 


\section{WHAT DO GRASSES LOOK LIKE?}

\section{ROOTS}

The root systems of grasses (Fig. 2) are always fibrous and the majority of the roots arise from the lower nodes of the stems. Because of the fibrous nature of the roots, they are excellent soil binders. When we pull up a grass plant, we remove only a small portion of the total root system, which in many species may reach a depth of six feet or more.

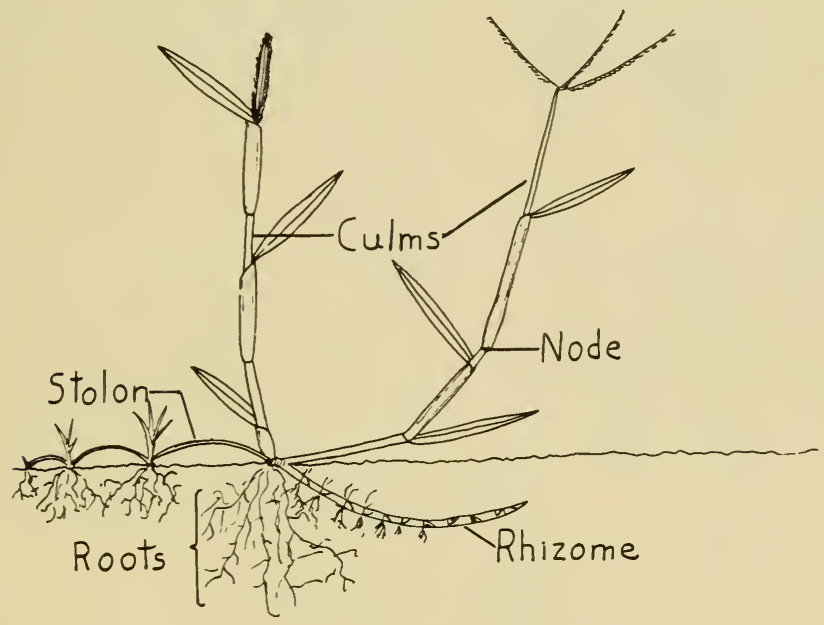

Figure 2

\section{STEMS}

The flowering stems or culms of grasses (Fig. 2) are jointed and usually round and hollow between the solid joints (nodes). They may branch, in which case a thin membrane, Hshaped in cross section, lies between the main culm and the branch. It is called a prophyllum (Fig. 3), and it grasps the main culm with two flanges and the branch with the other two. Thus it serves as a brace to the weak V-joint between the main stem and the branch. Stems may be erect, or with bent, knee-like bases (decumbent), or they may trail on the surface of the ground (stolons) and root at the nodes, or they may even grow in the top few inches of soil (rhizomes). The stems of grasses range in size from those like six-weeks fescue, a millimeter or two in diameter and a few centimeters tall, up to the giant bamboos, which may attain a height of $a$ hundred feet and a diameter of a foot or more.

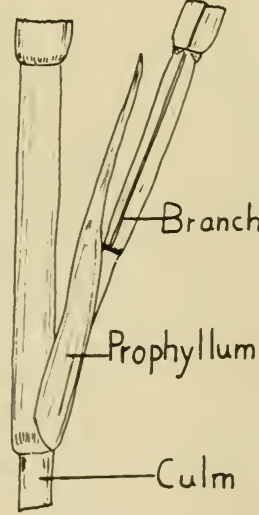

Figure 3 


\section{LEAVES}

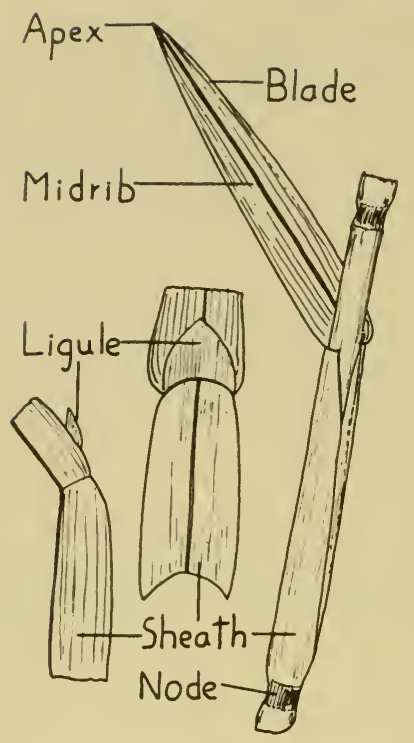

Figure 4

The leaves of grasses are always parallel-veined and generally have long, narrow blades. The foliage leaf of grasses (Fig. 4), consists of $a$ sheath, a ligule, and a blade. There is no petiole. The sheath is the split tubular portion surrounding the culm; the ligule is a little membrane-like or hairy collar which sticks up at the juncture of sheath and blade; the blade is the spreading portion of the leaf. It usually has a conspicuous midrib as well as numerous smaller nerves or veins parallel to the midrib. The tip, or apex, of the leat is sharp pointed. Little projections at the base of the leaf blade are called auricles. In a few genera, notably Bromus, Melica, Schizachne, and Glyceria, the leaf sheath has joined edges, forming a tube, much the same as in the Cyperaceae.

\section{FLOWER CLUSTERS}

The flower cluster or inflorescence (Fig. 5) of grasses is always made up of a number of subdivisions called spikelets. The spikelets
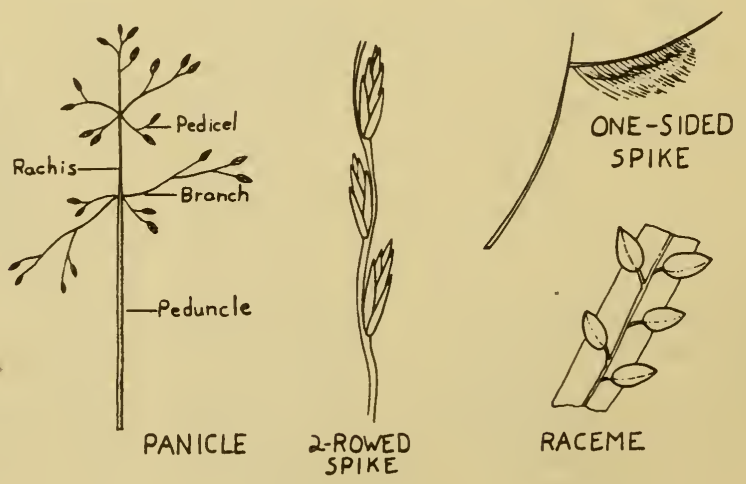

Figure 5 
are arranged in panicles, or two-rowed spikes, or one-sided spikes, or racemes. The parts of the inflorescence include the stalk or peduncle, the central axis or rachis, main and small branches, and the stalks of the individual spikelets or pedicels. At the base of each branch there may be found a little swelling, the pulvinus, which helps spread the branch of the inflorescence when it emerges from the sheath.

\section{SPIKELETS}

Since the flowers of grasses are minute, simple, and very similar, they are rarely used in classification. Instead, we look for differences in the bracts (modified leaves) which surround the flowers. The unit subdivisions of the inflorescence are called spikelets (Fig. 6). The

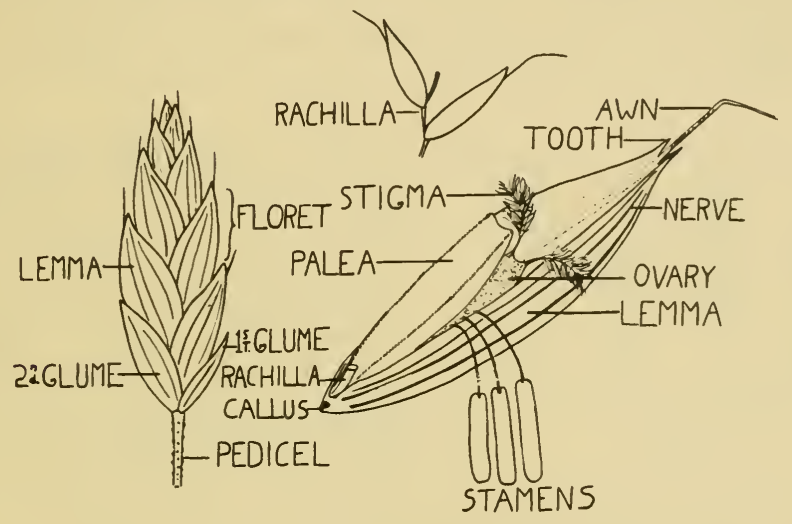

Figure 6

simplest sort of spikelet is merely a tiny scaly branchlet of flowers, each flower being surrounded by two bracts. At the base of this branchlet there are two bracts which have no flowers in their axils. These are the first and second glumes. The remainder of the spikelet is made up of flowering units called florets, which are arranged alternately in two rows on a central stalk, called a rachilla, which is usually concealed by the overlapping florets. Each floret consists of an outer bract or lemma and an inner bract or palea, with the naked flower between them. The lemma corresponds to an ordinary foliage leaf, the palea to the prophyllum, and the flower to a branch. During the brief time of flowering, two little blisters, the lodicules, which lie between the ovary of the flower and the lemma, swell up and force the lemma outwards. This allows the stigmas and stamens to protrude. The lodicules are the evolutionary vestiges of a calyx. If you can find smooth brome grass, orchard grass, or any one of many other grasses in bloom in the morning dew, you can usually observe the lodicules with a hand lens. The actual flower consists of two lodicules, three stamens with long slender filaments, and an ovary with two feathery 
stigmas. All grasses are wind pollinated except the few which are self pollinated within closed florets (cleistogamous). The lemma has a midrib and a number of smaller "veins" or "nerves" running roughly parallel to it, but converging toward the tip. The midrib of the lemma may be prolonged into a beard or bristle, called an awn. Rarely the lateral nerves also protrude. If the lemma is prominently folded along the midrib, it is said to have a keel. The hardened lower end of the lemma is called a callus. The palea always has two veins near the sides, but lacks a midrib. In some grasses the palea is small or lacking. Usually the spikelet has a stalk or pedicel, or this may be absent, as in wheat and rye, and then the spikelet is said to be sessile. Usually spikelets break up at maturity into individual florets, each of which will then bear a segment of the rachilla. Some spikelets, like those of switch grass and foxtail grass, do not break up, but are shed from the plant whole.

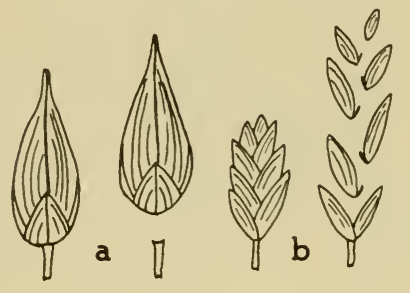

Figure 7

Often it is necessary to determine at what points the spikelets break or disarticulate. When the spikelets are mature and dry, they will disarticulate naturally, but if one has a rather immature plant, it may be necessary to tease the spikelets apart with needles and tweezers or with the finger nail in order to tell where the disarticulation will occur. There are two general types of disarticulation: below the glumes (Fig. 7, a), and above the glumes (Fig. 7, b). Spikelets which disarticulate below the glumes leave nothing on the plant except the stubs of the pedicels. Those which disarticulate above the glumes leave them on the plant. Spikelets of this type usually disarticulate between the florets as well.

Another feature of the spikelet which we may need to know is its shape in cross section. Spikelets may be round in cross section (Fig. $8, a)$, or flattened from the sides of the glumes and lemmas (laterally

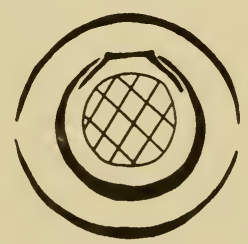

a

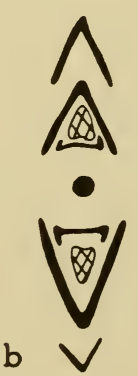

Figure 8

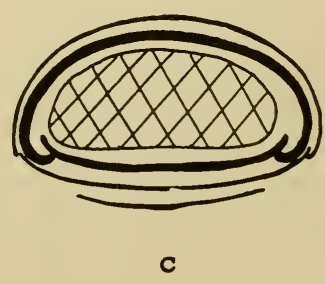

C 
compressed), as in Fig. 8, b; or flattened from the backs of the glumes and lemmas (dorsally compressed), as in Fig. 8, c.

The kind of spikelet pictured in Fig. 6 is probably the basic type, from which reduced or more complicated sorts have been derived by various changès. In studying other types of grass spikelets, we should mentally compare them with the basic type in order to decide which parts have been modified or eliminated. The following types of changes are common, and they characterize large groups of grasses:

1. The glumes may become large, covering the whole spikelets (oats and its relatives).

2. The upper florets may become eliminated, so that the spikelet is one-flowered (red top, timothy, and their relatives).

3. The lower florets may become sterile and much reduced in size, the upper one remaining fertile (canary grass, foxtail).

4. The glumes may become reduced to little ridges on the tip of the pedicel (rice, cut grass).

5. Either stamens or pistil may be eliminated, giving rise to spikelets or plants of one sex (salt grass, creeping love grass, Texas bluegrass, corn, Sorghum, wild rice).

\section{HOW TO COLLECT AND STUDY GRASSES}

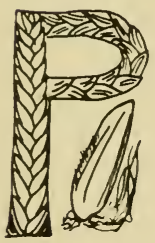

ROBABLY there is not a county in the United States where less than fifty to one hundred different species of grasses are to be found. Some will be very common and conspicuous, but others will be rare and hard to find. At first, all may look rather similar, so that sharp observation will be needed to detect even all of the common grasses around us. Don't be afraid to get down on hands and knees and crawl to get a good look. Each sort of habitat will have its own grasses: look in prairie, woodland, marsh, bog, ditches, corn or cotton fields, deserts, mountain meadows, or alpine summits, and you will probably be rewarded with a different set of species each time. Even in the same locality, new species come into flower throughout the spring, summer, and fall.

Grasses are easy to collect and prepare, so one should always take care to make good specimens, which will be a pleasure to study later. 
The tools needed for collecting grasses are simple. First of all, you will need some sort of digger, so that you can get the important underground parts of the plants. I use a long, stout screwdriver, but large hunting knives, geologists picks, or entrenching tools are also satisfactory. Whatever tools you use, be sure to get the parts of the plant that lie below the ground level. Frequently an otherwise good specimen becomes very difficult to identify because the collector has neglected these structures.

After digging a specimen from the ground, one should knock the dirt from the roots or wash them clean. If the plant is too bulky to press flat it may be subdivided and some of the extra inflorescences saved to provide spikelets for dissection. Each specimen is placed in a single folded newspaper sheet ( $12 \times 16$ inches as folded) for drying. Information which you would like to

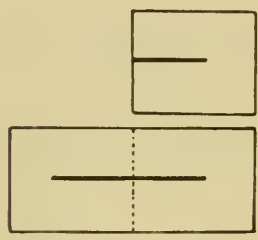

Figure 9 keep, such as the location, type of habitat, and the date, should be written on the margin of the paper. If the specimen is too long to fit in a folder, it may be doubled back one or more times. Crumpled or tangled parts should be smoothed out. The bent stems can be held in place by little slips of card with a slit cut in each (Fig. 9). The grass specimens in their paper folders may be carried between sheets of beaverboard or plywood, with a light strap around the bundle, for periods as long as a day, before it is necessary to dry them.

Final drying of the specimens is accomplished by placing them, in their folders, between $12 \times 18$ inch blotters made of builders' deadening felt (obtainable from lumber yards, in rolls), or between thick pads of newspapers. The specimens must be kept under pressure until dry, either by placing boards on the sides of the bundle and strapping it tightly, or by placing heavy weights on top of the bundle. Each day the damp blotters or newspaper pads must be removed and replaced with dry ones. The damp blotters may be dried by laying them out in the sun on dry paving (not grass) for a short while. In wet weather, the blotters can be cautiously dried in a warm oven. Usually grass specimens dry in a few days. After drying, they may be handled in the paper folders, but they will keep better if they are mounted on paper.

One may mount specimens in large scrapbooks, or better still, on standard herbarium sheets which may be purchased from biological supply houses. Specimens may be glued to paper by placing them momentarily on a large sheet of glass covered with thin glue, brushed to a thin uniform layer. Fish glue, carriage glue, or LaPages Special 
A Tin Paste are satisfactory for this purpose.

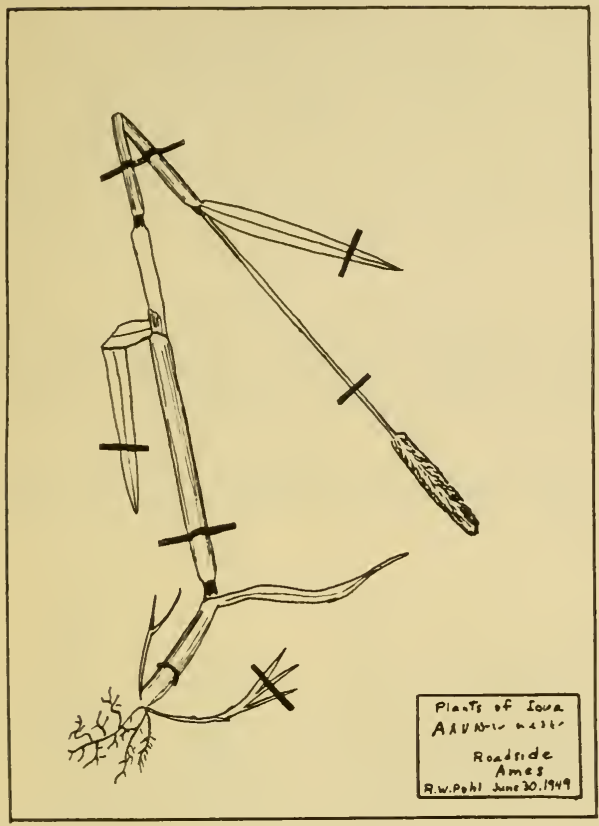

Figure 10
Each specimen, after gluing, is then dropped onto a sheet of paper. Since grasses are often quite waxy, they do not always stick well and should also be sewed to the sheet with string or fastened down with narrow strips of gummed cloth tape (see Fig. 10). Do not use "Scotch" tape, since it becomes sticky and brittle with age or pulls loose. A label, bearing the name of the plant, the place and date of collection, and any other pertinent information, should be glued in the lower right corner of the sheet. Loose spikelets or other small parts may be placed in small coin envelopes

which are glued to the sheet.

When considerable numbers of specimens are needed, for use in classes or for display, they may be preserved by tying them in sheaves and allowing them to hang head down until dry.

The equipment which one needs for studying grasses is simple and inexpensive. $A$ good hand lens, of ten to fifteen power is essential, and should always be carried when collecting. A pair of dissecting needles, well sharpened, are needed. A small scalpel, made by heating and pounding out the tip of a large needle, then retempering and sharpening the edge, is a great help. These can sometimes be purchased through biological supply houses. $A$ pair of good tweezers, preferably with curved tips, a razor blade, and a millimeter scale complete the equipment. When available, a low power binocular microscope will speed and simplify the job of seeing. If such a microscope is not obtainable, one might mount a hand lens on an improvised stand, so as to leave both hands free for dissecting the specimens. To soften dried grass spikelets so that they may be dissected more readily, one may apply a few drops of a strong solution of Dreft or $\mathrm{Vel}$ in water. 


\section{HOW TO RECOGNIZE THE TRIBES OF GRASSES}

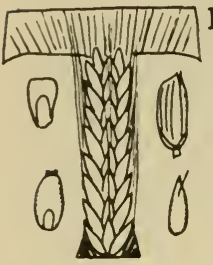

HE common grasses of the United States are grouped into thirteen tribes, or subdivisions of the family. With a little practice, it is usually possible to determine the tribe to which a given grass belongs very quickly, thereby making it unnecessary to go through a portion of the key. The following summaries of the characteristics of the different tribes should help you to recognize them.

Subfamily FESTUCOIDEAE. Spikelets with one to numerous florets; sterile florets, if present, usually at the tip of the spikelet; spikelets laterally compressed or round in cross section; disarticulation usually above the glumes.

Tribe I. BAMBUSEAE. Tall plants, with woody perennial culms. Spikelets rarely present. Page 15.

Tribe II. FESTUCEAE. Spikelets with several to many florets; glumes not reaching the tip of the lowermost floret; disarticulation usually above the glumes; inflorescence a panicle. Fig. 11. Pages 23-84.

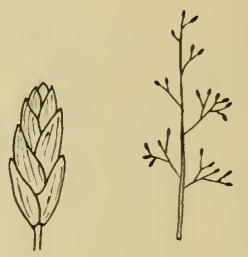

Figure 11

Tribe III. HORDEAE. Inflorescence a single terminal spike, with spikelets in rows on opposite sides of the rachis. Spikelets with one to several florets, usually disarticulating above the glumes. Fig. 12. Pages 85-94.

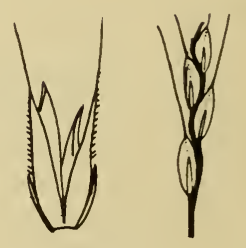

Figure 12

Tribe IV. AVENEAE. Spikelets similar to those of the Festuceae, but with much enlarged glumes, usually covering the entire spikelet. Disarticulation above or below the glumes; inflorescence a panicle. Fig. 13. Pages 95-101.
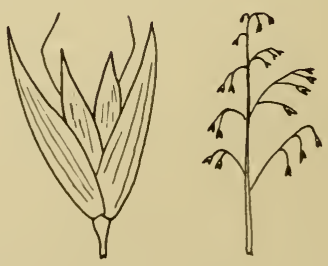

Figure 13 
Tribe V. AGROSTIDEAE. Spikelets consisting of two glumes and a single fertile floret. There are never any sterile or rudimentary florets. Spikelets disarticulating above or below the glumes. Inflorescence an open or spikelike panicle. Fig. 14. Pages 102-129.

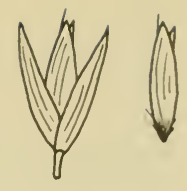

Figure 14

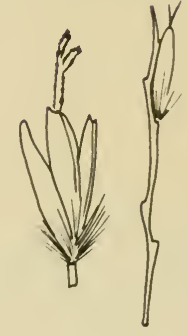

Figure 15
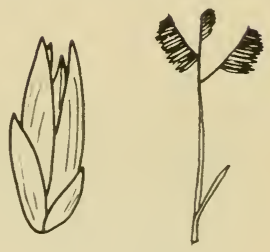

Figure 16

Tribe VII. CHLORIDEAE. Spikelets with one to several florets, arranged in two rows on the under-side of one to many spikes. Fig. 16. Pages 131-143.

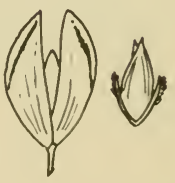

Figure 17

Tribe VIII. PHALARIDEAE. Spikelets with enlarged glumes and one perfect terminal floret, with one or two staminate or sterile florets or little scales below it. The sterile florets fall attached to the perfect one. Disarticulation above the glumes. Fig. 17. Pages 144, 145.

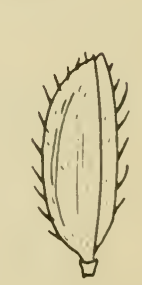

Tribe IX. ORYZEAE. Each spikelet consists of a single fertile floret. The glumes are lacking or reduced to minute ridges at the tip of the pedicel. Fig. 18. Pages 146, 147. 
Tribe X. ZIZANIEAE. Aquatic grasses; spikelets consisting of a single staminate or pistillate floret; glumes lacking or reduced to ridges at the tip of the pedicel. Fig. 19. Pages 147, 148.

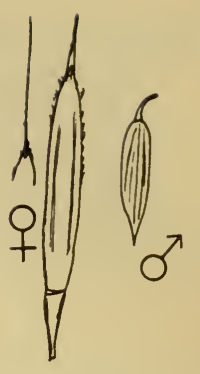

Figure 19

Subfamily PANICOIDEAE. Spikelets with a single perfect floret and a sterile one below it. The spikelet consists of a first glume (sometimes small or absent), a second glume as long as the whole spikelet, a sterile lemma, and a fertile floret. The spikelets are dorsally compressed and disarticulation is always below the glumes.

Tribe XI. PANICEAE. The glumes and sterile lemma are thinner in texture than the fertile lemma and palea, which are hard or leathery. The first glume is usually much shorter than the second. Spikelets borne in panicles or racemes. Fig. 20. Pages 149-175.

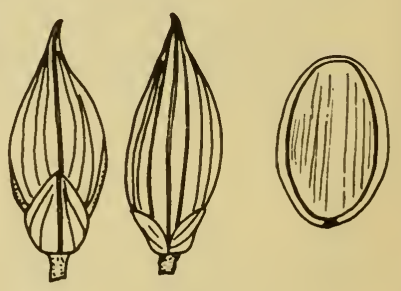

Figure 20

Tribe XII. ANDROPOGONEAE. Spikelets with two equal hardened glumes, which completely inclose the thin, delicate sterile lemma and fertile floret. Spikelets borne in racemes or spikes, a pair of them borne at each joint of the rachis. One spikelet of each pair is perfect and fertile, the other usually staminate, sterile, or rudimentary. Fig. 21. Pages 176-183.

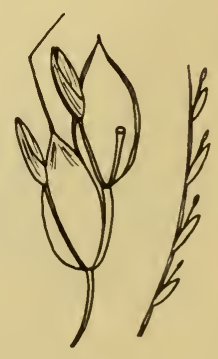

Figure 21 
Tribe XIII. TRIPSACEĀE. Stout, tall, corn-like plants, usually with solid stems. Spikelets are all unisexual, the staminate ones borne in one or more terminal racemes (sometimes forming a tassel), the pistillate ones borne in bony beads or rachis joints, or on cobs. The only common genera except Zea (corn) are Tripsacum (gama grass) and Job's Tears (Coix). Fig. 22. Pages 184, 185.

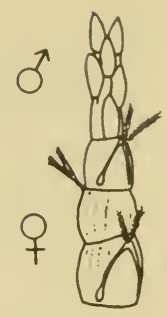

Figure 22

\section{SOME USEFUL BOOKS ON GRASSES}

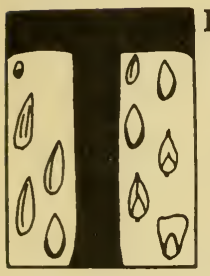

HE following short list includes some of the principal books useful for identification or study of American grasses. The list is not intended to be complete, and some books which are old or unavailable have been omitted. You will find that a book on the grasses of your own state, or an adjacent one, will often make identification easier than such comprehensive works as Hitchcock's Manual, which covers a large and diverse area.

Blomquist, H. L. 1948. The grasses of North Carolina. pp. vi plus 276. Keys, descriptions and illustrations. Duke Univ. Press. Durham.

Beetle, A. A. 1947. Distribution of the native grasses of California. Hilgardia 17: 309-357. Maps of distributions and discussions of ranges of the species; no keys or descriptions.

Chase, Agnes. 1937. First book of grasses. Revised edition. pp. xiii plus 125. Good, well-illustrated explanations of spikelet structure for the various tribes. W. A. Silveus, San Antonio, Tex.

Core, E. L., E. E. Berkley, and H. A. Davis. 1944. West Virginia grasses. Bull. 313, West Va. Agric. Expt. Sta. pp. 96. Keys, descriptions, illustrations.

Deam, C. C. 1929. Grasses of Indiana. pp. 356. Keys, descriptions, maps, illustrations. Pub. 82, Indiana Dept. of Conservation. Indiamapolis.

Dore, W. G. and A. E. Roland. 1942. The grasses of Nova Scotia. Proc. Nova Scotia Instit. of Sci. XX: 177-288. Keys, discussions, illustrations, maps.

Fassett, N. C. 1951. Grasses of Wisconsin. pp. 173. Keys, maps, illustrations. Univ. of Wisconsin Press. Madison.

Featherly, H. I. 1946. Manual of the grasses of Oklahoma. Bull. 21, Okla. Agric. and Mechan. College. pp. 137. Keys, descriptions, illustrations. 
Gates, F. C. 1937. Grasses in Kansas. Rept. of Kansas State Board of Agric., Vol. LV, No. 220-A. pp. 349. Keys, descriptions, illustrations of species, maps.

Harrington, H. D. 1946. Grasses of Colorado. pp. 167, plus index. Keys and descriptions, no illustrations. Mimeographed. Colorado A. and M. College, Fort Collins.

Hitchcock, A. S. 1936. The genera of grasses of the United States, with special reference to the economic species. U. S. Dept. of Agric. Bull. 772, revised ed. pp. 302 . Keys to genera, illustrations, discussions of important species. Supt. of Documents.

Hitchcock, A. S. 1951. Manual of the grasses of the United States. U. S. Dept. of Agric. Misc. Publ. 200, revised edition (by Agnes Chase). pp. 1051. Abundantly illustrated. This is a very important publication on American grasses, but rather large and complex for the beginner. Supt. of Documents, Washington, D. C.

Mosher, Edna. 1918. The grasses of Illinois. Ill. Agric. Expt. Sta. Bull. 205. pp. 261-425. Keys, descriptions, illustrations.

Norton, J. B. S. 1930. Maryland grasses. Md. Agric. Expt. Sta. Bull. 323. Keys, brief descriptions, key to vegetative characteristics of grasses.

Pohl, Richard W. 1947. A taxonomic study on the grasses of Pennsylvania. American Midland Naturalist 38: 513-604. Keys and habitat notes, no descriptions or illustrations.

Pool, Raymond J. 1948. Marching with the grasses. pp. xii plus 210. This is a book on the economic botany of grasses. Not useful for identification of individual genera or species. Univ. of Nebraska Press. Lincoln.

Silveus, W. A. 1933. Texas grasses. pp. xlvi plus 782. Illustrations, keys, and descriptions. Pub. by the author. San Antonio.

U. S. Dept. of Agriculture. 1948. GRASS: The yearbook of agriculture 1948. Contains numerous articles on grasses, legumes, grasslands. One section is on common agricultural grasses. Illustrations. Supt. of Documents. Washington, D. C.

U. S. Forest Service. 1937. Range plant handbook. pp. xxvi plus 512. One section on grasses. Illustrations, detailed notes on structure, uses by grazing animals, range, etc. No keys. Supt. of Documents. Washington, D. C. 


\section{PICTURED-KEYS TO COMMON AMERICAN GRASSES}

la. Plants with woody perennial culms, one to many meters tall (bamboos). Fig. 23.

\section{Tribe I. BAMBUSEAE}

CANE

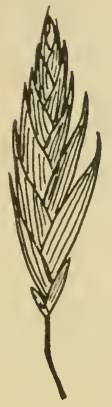

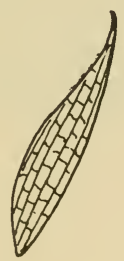

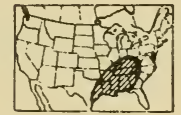

Figure 23

Arundinaria gigantea (Walt.) Chapm.

Stems (canes) woody, perennial, reaching as much as $10 \mathrm{~m}$. in height; plants rarely flowering. Cane grows in dense colonies, called canebrakes, in river bottomlands from Virginia to the Ohio Valley and southward to eastern Texas and Florida. The canes are used for fish poles, basketry, and in a variety of other ways. The young shoots and leaves are eagerly taken by domestic animals. A smaller form of cane, with culms usually less than $2 \mathrm{~m}$. tall, is called Arundinaria tecta (Walt.) Muhl.

While cane is our only native bamboo, a number of other species are sometimes grown for ornament. Hardiest of these is Pseudosasa japonica, a small bushy bamboo reaching $2-3 \mathrm{~m}$. tall, spreading by rhizomes and forming dense colonies.

1b. Plants with non-woody annual culms, usually less than $2 \mathrm{~m}$. tall

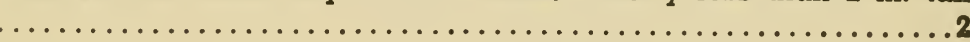

2a. Some or all of the spikelets inclosed in bony beads or spiny burs

2b. Spikelets not inclosed in beads or burs.................

3a. Pistillate spikelets only inclosed in smooth bony beads.....4

3b. Perfect spikelets inclosed in burs covered with hooks or spines

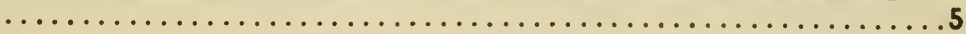


4a. Low, creeping perennial plants, rooting at the nodes; staminate and pistillate spikelets on separate plants. Fig. 24....... .......See Fig. 247 (Buchloe dactyloides)

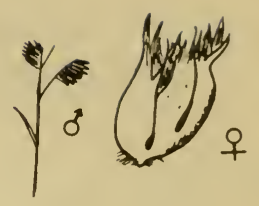

Figure 24

4b. Erect, coarse grasses; staminate spikelets at the tip of the inflorescence; bony pistillate portion at the base. Fig. $25 \ldots \ldots \ldots \ldots \ldots \ldots \ldots$. TRIBE XIII, TRIPSACEAE, page 184

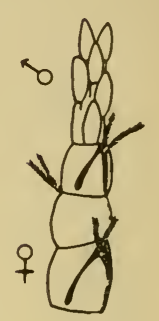

Figure 25

5a. Spines of the burs hooked at the tips see Fig. 244. (Tragus berteronianus)

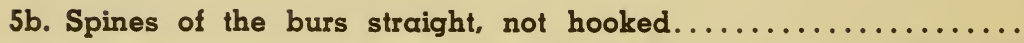
...................... Fee Fig. 282. (Cenchrus pauciflorus)

6a. Spikelets falling from the plants in clusters of 2-many, never

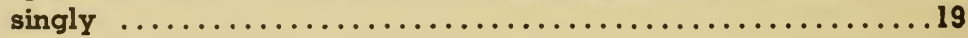

6b. Spikelets either falling singly or breaking up into florets and leaving the glumes behind on the plant...................

7a. Spikelets of two unlike kinds (one staminate and the other pistillate) in the same or different inflorescences.............8

7b. Spikelets alike and nearly always with perfect flowers, or sometimes perfect and staminate or rudimentary ones borne to-

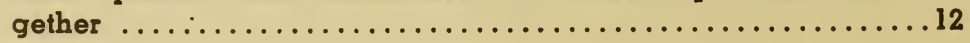


8a. Plants aquatic; pistillate spikelets never on cobs nor inclosed in bony rachis joints; staminate spikelets with a single flower: glumes absent or reduced to minute ridges. Fig. $26 \ldots \ldots \ldots$ .TRIBE X, ZIZANIEAE, page 147

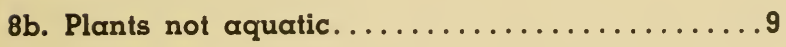

9a. Staminate and pistillate spikelets on the same or separate plants; pistillate spikelets not on a cob nor imbedded in bony rachis joints...10

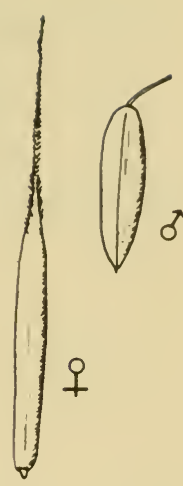

Figure 26

9b. Staminate and pistillate spikelets on the same plant; pistillate spikelets on a cob or imbedded in bony joints of the rachis..... .TRIBE XIII, TRIPSACEAE, page 184

10a. Pistillate spikelets with 3-awned lemmas, the staminate awnless:

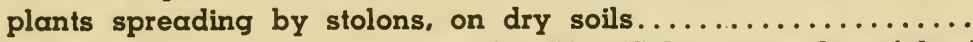
see Fig. 46. (Scleropogon brevifolius)

10b. Spikelets not awned

11a. Lemmas glabrous, stiff and leathery, with 9-11 faint nerves; plants of salty or alkali soil.............see Fig. 45. (Distichlis stricta)

11b. Lemmas soft, papery, with 5 nerves, often with a cottony web attached to the callus............see Fig. 146. (Poa arachnifera) 
12a. Spikelets with only one perfect floret, sometimes with unlike staminate, empty, or rudimentary ones above or below it.......13

12b. Spikelets with several perfect or pistillate florets

13a. Entire spikelets breaking from the plant when ripe. Fig. $27 \ldots \ldots \ldots \ldots \ldots 14$

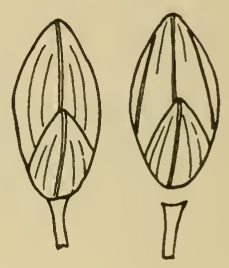

Figure 27

13b. Spikelets when ripe breaking off above the glumes, leaving them on the plant. Fig. 28

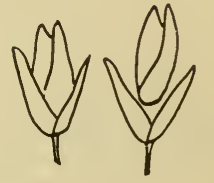

Figure 28

14a. Both glumes absent or reduced to minute ridges below the lemma and palea; spikelets strongly laterally flattened, with strongly keeled lemma and palea. Fig. 29... TRIBE IX, ORYZEAE, page 146

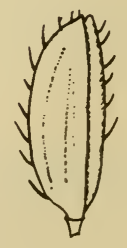

Figure 29

14b. At least one glume well developed; spikelets flat or round in

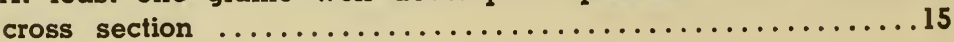


15a. Spikelets laterally compressed or round in cross section (Fig. 30); no sterile florets below the perfect ones........16

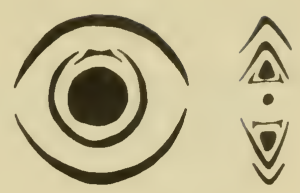

Figure 30

15b. Spikelets usually dorsally compressed (Fig. 31). consisting of a perfect floret and an empty lemma or staminate floret and two (rarely one) glumes below it..........18

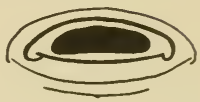

Figure 31

16a. Spikelets sessile or nearly so, borne along the lower sides of one to many spikes............ TRIBE VII, CHLORIDEAE, page 131

16b. Spikelets borne on pedicels in panicles, not exclusively on the lower sides of branches..........................

17a. Spikelets with $\alpha$ single perfect floret and no sterile or rudimentary ones. Fig. $32 \ldots \ldots \ldots \ldots \ldots$ TRIBE V, AGROSTIDEAE, page 102

17b. Spikelets with two florets, the lower perfect and the upper staminate; both glumes longer than the florets.............. see Fig. 190. (Holcus lanatus)

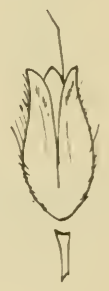

Figure 32

18a. Glumes and sterile lemma soft and papery; first glume shorter than the spikelet; fertile lemma and palea stiff or leathery. Fig. 33 ........... TRIBE XI, PANICEAE, page 149

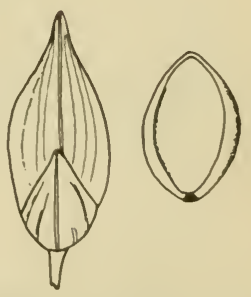

Figure 33 
18b. Glumes thicker and stiffer than the delicate fertile lemma and palea; both glumes as long as the spikelet; spikelets paired, in racemes; one spikelet of each pair sessile or on a short pedicel, the other on a longer pedicel, sometimes rudimentary. Fig. $34 . \ldots \ldots \ldots \ldots \ldots$ ... TRIBE XII, ANDROPOGONEAE, page 176

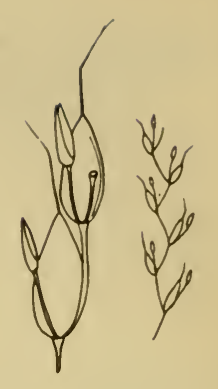

Figure 34

19a. Spikelets borne in two rows along the lower side of the rachis of numerous spikes, which are borne in a raceme along a common rachis; spikes dropping from the rachis whole. Fig. $35 \ldots \ldots \ldots \ldots \ldots \ldots \ldots \ldots$ TRIBE VII, CHLORIDEAE, page 131

19b. Spikelets not borne in rows along the lower sides of the l-many spikes; spikes remaining whole or breaking up into groups of spikelets or single spikelets. .20

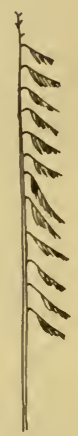

Figure 35

20a. Rachis breaking up into joints at maturity, each joint bearing 2 -3 spikelets

20b. Rachis remaining intact, the groups of spikelets falling from it..21

2la. Spikelets falling with a ring of long hairs attached............ see Fig. 284. (genus Pennisetum)

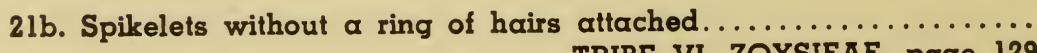


22a. Each joint bearing 2 spikelets, usually one sessile and perfect and one pedicellate and staminate or sterile; glumes thick, the fertile

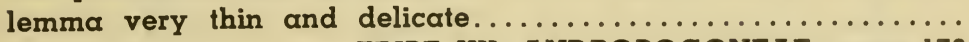
TRIBE XII, ANDROPOGONEAE, page 176

22b. Each joint bearing 3 spikelets, the lateral two often sterile and reduced in size; lemmas not thin and delicate.............. TRIBE III, HORDEAE, page 85

23a. Inflorescence a panicle, sometimes dense or contracted; each

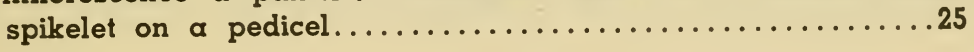

23b. Inflorescence of one or more spikes, the spikelets sessile ...........................24

24a. Spike single, terminal, with the spikelets borne in rows on opposite sides of the rachis. Fig. $36 \ldots \ldots \ldots \ldots$ .TRIBE III, HORDEAE, page 85

24b. Spikes 1 -many, the spikelets arranged in two rows on the lower side of the rachis of each spike. Fig. 35

TRIBE VII, CHLORIDEAE, page 131

25a. Spikelets consisting of two (rarely one) glumes and a single perfect floret, no staminate or rudimentary ones with it. Fig. $37 \ldots \ldots \ldots \ldots \ldots \ldots \ldots$ TRIBE V, AGROSTIDEAEE, page 102

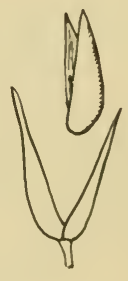

Figure 37

25b. Spikelets with a perfect terminal floret and one or two staminate or rudimentary ones, often reduced to little scales, below it...26 
26a. Spikelets with two similar florets, the lower staminate and with a bent awn, the upper perfect and with a short

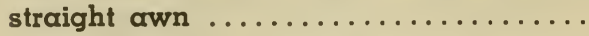
..see Fig. 179. (Arrhenatherum elatius)

26b. Spikelets with a single perfect floret and 1 or 2 unlike staminate or sterile florets or little scales borne below it........ ...Fig. 38. TRIBE VIII, PHALARIDEAE,

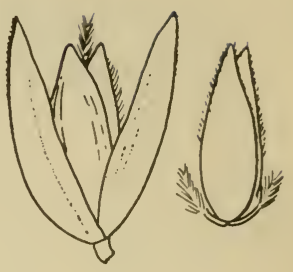

Figure 38 page 144

27a. Spikelets borne in one or more spikes, sessile or rarely on short

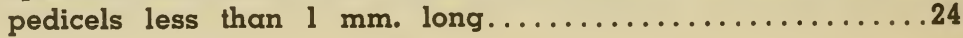

27b. Spikelets in open or dense panicles, each spikelet on a pedicel. .28

28a. Glumes not reaching above the tip of the lowest floret; lemmas awnless or with one or more awns arising at the tip or between teeth. Fig. 39..... TRIBE II, FESTUCEAE, page 23

28b. Glumes reaching beyond the tip of the lowest

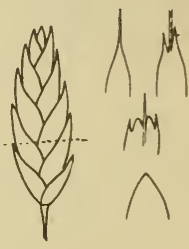

Figure 39 floret and usually beyond the uppermost floret; lemmas awnless or with a single awn arising from the back or between two teeth. Fig. 40..29

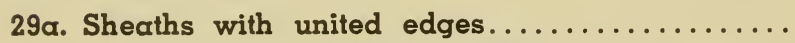
TRIBE II, FESTUCEAE, page 23

29b. Sheaths with overlapping edges..........30

30a. Lemmas with 3 prominent, conspicuously hairy nerves, all 3 extending into short awns - see Fig. 52 and following. (genus Tridens)

30b. Lemmas not as above..................

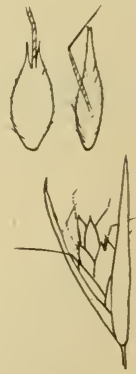

Figure 40

3la. Tall stout grasses 1 -several $\mathrm{m}$. tall; lemmas or rachilla joints covered with long straight hairs which conceal the spikelets TRIBE II, FESTUCEAE, page 23

31b. Grasses of small to moderate stature, seldom over $1 \mathrm{~m}$. tall; lemmas and rachilla joints smooth or hairy, but not concealed by long hairs................ TRIBE IV, AVENEAE, page 95 


\section{TRIBE II. FESTUCEAE}

1a. Spikelets all similar in appearance (rarely unisexual) .......

lb. Spikelets of 2 different kinds..................

2a. Lemmas undivided or with not more than 3 awns at the tips.... 3

2b. Lemmas bearing at the tip 9 or more awns, which are feathery on the lower half. Fig. 41.

PAPPUS GRASS

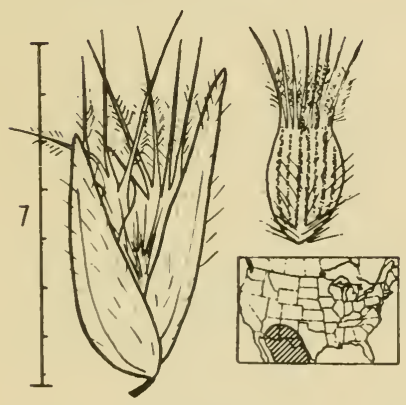

Figure 41
Enneapogon desvauxii Beauv.

Perennial; tufted; culms $20-40 \mathrm{~cm}$. long; panicles spikelike. Leaf blades threadlike, about $1 \mathrm{~mm}$. wide. The lower sheaths are somewhat swollen, and contain cleistogamous spikelets which have nearly awnless lemmas. Several related species in the genus Pappophorum lack the feathery hairs on the awns. Dry desert hills and plains, from western Texas to Arizona and southward. Forage value low. September - October. Also called Pappophorum wrightii.

3a. Rachilla joints or backs of the lemmas bearing long straight hairs which give the spikelets $\alpha$ silky appearance; tall grasses, the culms

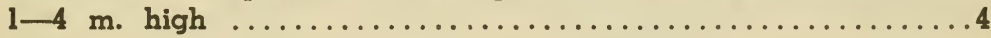

3b. Rachillas and lemmas not covered with hairs which cover the spikelet; (lemmas sometimes hairy on nerves or callus); plants

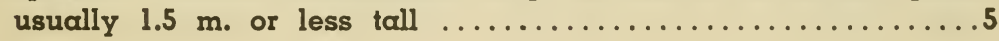


4a. Long hairs borne on the rachilla; lemmas smooth. Fig. 42.

REED

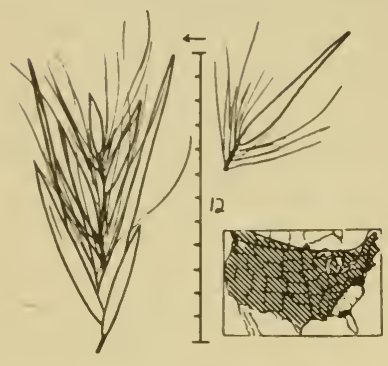

Figure 42

Phragmites communis Trin.

Reed is a tall perennial grass, reaching $4 \mathrm{~m}$. or more in height, with smooth, polished stems and long and very broad leaves. The plants spread widely by vigorous rhizomes, forming great colonies along the margins of streams and in marshes and ditches. In autumn the large panicles become very feathery because of the hairy rachillas. The lowermost floret of the spikelet is staminate or sterile. Reed is widespread in the United States and is also known from all of the continents of the world. Fossil rhizomes of reed have been found in Europe, making it one of the few grasses known from past geological ages. July-October.

4b. Rachilla not hairy; lemmas covered with long hairs. Fig. 43.

GIANT REED

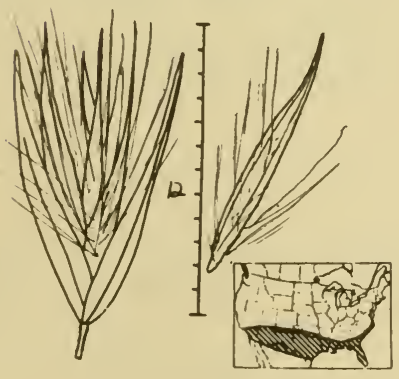

Figure 43

Arundo donax L.

\begin{abstract}
Perennial. This is one of the most spectacular of grasses of the temperate zone. The great culms reach a height of $6 \mathrm{~m}$., and a thickness of $5 \mathrm{~cm}$. or more. The plumelike panicles which are produced by well established clumps may reach a length of $60 \mathrm{~cm}$. Altogether, the plants resemble bamboos closely, but the stems do not persist over winter. Giant reed is a native of Europe, but is cultivated and naturalized in
\end{abstract} our southern states, and has proved hardy in cultivation as far north as central lowa. The tough rind of the culms is used to make clarinet reeds. Fall. 
5a. Staminate and pistillate spikelets similar but on separate plants. 6

5b. Spikelets all perfect $\ldots \ldots \ldots \ldots \ldots \ldots \ldots \ldots \ldots \ldots \ldots \ldots$

6a. Plants annual, spreading extensively by delicate stolons, forming flat mats on muddy ground....23a

6b. Plants perennial, spreading by rhizomes; culms erect, the plants not forming flat mats..............

7a. Lemmas pubescent or with a cottony web of hairs at the base. Fig. $44 \ldots \ldots \ldots \ldots \ldots \ldots \ldots \ldots \ldots$.

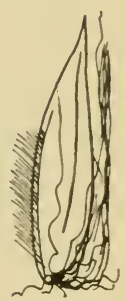

Figure 44

7b. Lemmas glabrous; plants of salty or alkali soils. Fig. 45.

\section{SALT GRASS}

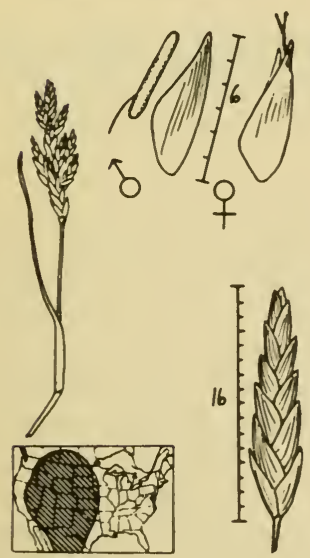

Distichlis stricia (Torr.) Rydb.

Perennial; spreading by stiff, scaly rhizomes; plants $10-40 \mathrm{~cm}$. tall. The salt grasses are coarse, stiff plants of saline or alkali flats in the drier parts of the western states and in the coastal salt marshes. $D$. stricta is confined to the interior of the western United States. In desert areas, it is eaten readily by cattle, but it is seldom taken where more succulent forage is available. April-September.

Distichlis spicata (L.) Greene, a very similar species, grows in brackish marshes along our entire Atlantic, Gulf and Pacific Coasts.

Figure 45 
$8 a$. Spikelets unisexual, the pistillate ones with lemmas each bearing 3 long awns, the staminate ones awnless; stolon-bearing plants of the southwestern states. Fig. 46.

\section{BURRO GRASS}

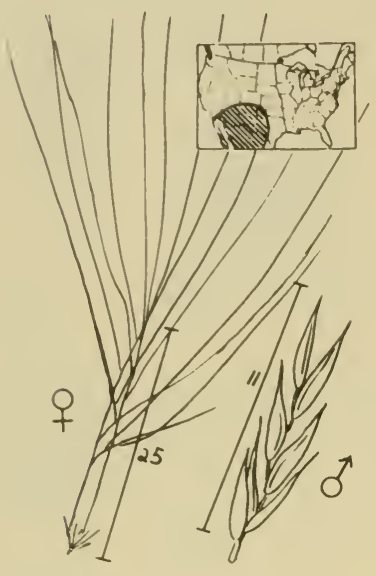

Figure 46

\section{Scleropogon brevifolius Phil.}

Burro grass is a low perennial, $10-20$ $\mathrm{cm}$. tall, spreading by stolons and making patches. Staminate and pistillate inflorescences on the same or different plants. The inflorescences are small tufts of a few erect spikelets. Each pistillate spikelet has a number of florets, which are shed from the glumes as a unit, covered with numerous awns. Each lemma looks much like a floret of Aristida, with three long awns. The sharp awns and callus of the pistillate lemmas can penetrate hair, wool, and facial tissues of grazing animals. Burro grass tends to replace more desirable grasses on overgrazed lands of the arid Southwest. Forage value very low. June-September.

8b. Spikelets perfect or sterile, the lemmas awnless or with single awns; tufted plants of humid areas; stolons lacking. Fig. 47.

CRESTED DOGTAIL.

Cynosurus cristatus L.

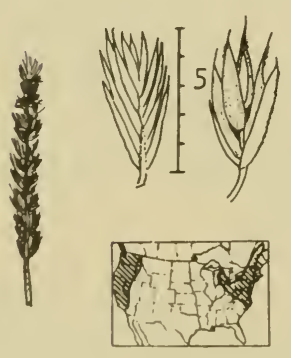

Figure 47

Perennial; tufted, culms $30-60 \mathrm{~cm}$. tall. The sterile spikelets are paired with fertile ones in the same inflorescence. The sterile spikelet is made up of slender empty awned lemmas. Inflorescence a dense, spikelike panicle. Dogtail is a European grass which has been imported for use in lawn and meadow seed mixtures. It is occasionally found in lawns, pastures and waste places in the eastern states and also in the Pacific Northwest. Apparently it has little value for forage. June -August. 
9a. Lemmas with 3 prominent nerves (the midrib and one on each side of it); nerves often hairy. Fig. $48 \ldots \ldots \ldots \ldots \ldots \ldots \ldots$

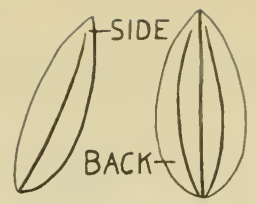

Figure 48

9b. Lemmas with 5 or more nerves, which may be inconspicuous. Fig. $49 \ldots \ldots \ldots \ldots 42$

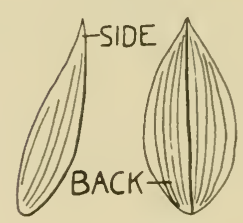

Figure 49

10a. Inflorescence small, dense, with few spikelets, partially surrounded by the leaves; small plants of the plains and deserts of the West .11

10b. Inflorescence an open or dense panicle which is supported above the leaves on a peduncle..........................

1la. Lemmas long-hairy over the back; spikelets not concealed in leaf sheaths

11b. Lemmas long-hairy only on the margins; spikelets concealed in the upper sheaths; sprawling, mat-forming plants........... .See Fig. 248. (Munroa squarrosa)

12a. Nerves or callus of the lemmas pubescent............13

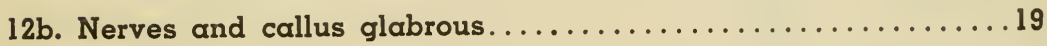

13a. Nerves of lemmas conspicuously pubescent; plants lacking rhi-

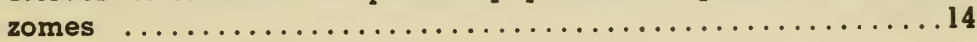


13b. Nerves of lemmas glabrous, the callus with a tuft of long hairs; plants with slender, elongated rhizomes. Fig. 50.

BLOWOUT GRASS

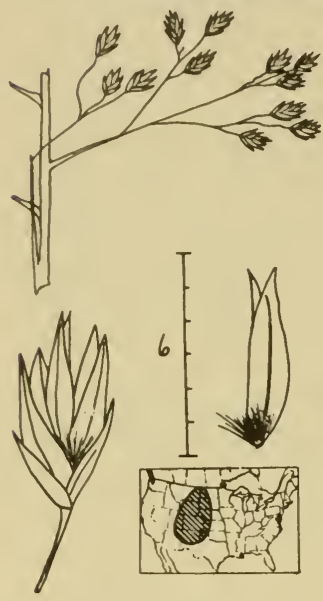

Redfieldia flexuosa (Thurb.) Vasey

Perennial; culms $60-100 \mathrm{~cm}$. tall; panicles large, pyramidal; leaf blades smooth and tough, elongated, inrolled. The spikelets when mature are fan-shaped, with conspicuous cottony tufts visible from the side. Because of the numerous long, slender rhizomes, blowout grass is able to keep pace with the shifting sands and eventually bind dunes into place. It is an important sand-binding grass on sandy plains from South Dakota to Oklahoma and Arizona. August-October.

Figure 50

14a. Palea not fringed with long hairs; plants perennial........15

14b. Palea fringed with long hairs on its upper half; plants annual, with weak, shallow root systems. Fig. 51 .

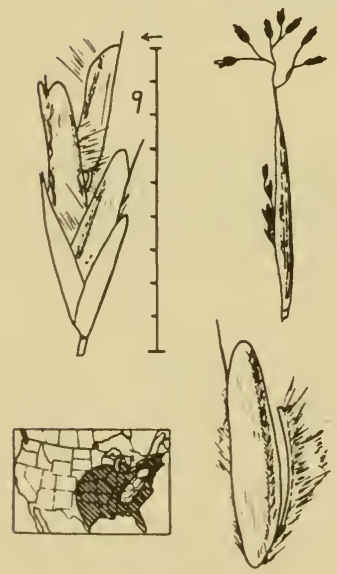

Triplasis purpurea (Walt.) Chapm.

Figure 51

Triplasis americana Beauv. is a similar species of the southeastern states. It is perennial and the lemmas have awns about as long as the body.

Annual; tufted; culms $30-75 \mathrm{~cm}$. long, erect or spreading. 'In late season, the herbage may become quite reddish. The small terminal inflorescence usually protrudes somewhat from the uppermost sheath, but the axillary panicles are concealed in the swollen sheaths and have cleistogamous spikelets. Common on sandy lands. July-October. 
15a. Spikelets in open or dense panicles which are borne above the leaves; plants without stolons..................... 16

15b. Spikelets in dense, cottony tufts which are exceeded by clusters of threadlike leaves; plants low, spreading by stolons. Fig. 52.

FLUFFGRASS

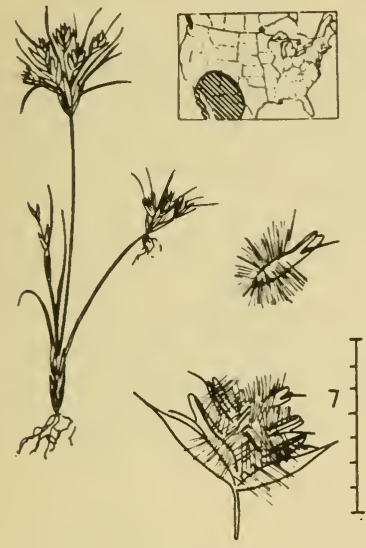

Figure 52

Tridens pulchellus (H. B. K.) Hitch.

Perennial; tufted at first, then spreading by short stolons; usually less than $15 \mathrm{~cm}$. tall. The entire plant consists of a tuft of threadlike basal leaves, from which arise culms which have a single long internode and bear a cluster of spikelets and leaves at the summit. These culms soon bend over and root at the tip. This process may be repeated until a mat of the plant is built up. Fluffgrass is found on thin soils, overgrazed lands, and deserts. Forage value negligible; usually regarded as an indicator of overgrazing. Also known as Triodia pulchella. April-October.

16a. Panicles dense, the branches short and close to the rachis, with overlapping spikelets; spikelets not deep purple..........17

16b. Panicles large and open, with spreading branches; spikelets deep reddish purple. Fig. 53.

\section{PURPLETOP}

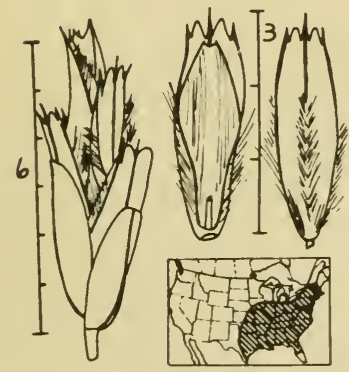

Figure 53
Tridens flavus (L.) Hitch.

Perennial; tufted; culms $1-1.5 \mathrm{~m}$. tall; panicles graceful and open, up to $35 \mathrm{~cm}$. long; leaf blades smooth, flat, 3-10 $\mathrm{mm}$. wide. The three nerves of the lemma protrude as little points. Open or partially shaded grassy places. Purpletop is eaten by livestock to some extent. It is attractive and colorful and might be grown as an ornamental. Also known as Triodia flava. August-October.

Tridens chapmani (Small) Chase is somewhat similar. It has a stiffer and more open panicle. $\bar{A}$ circle of hairs extends completely around the base of each main and secondary panicle branch. Dry woods, mostly on the Coastal Plain, New Jersey to Texas, north to Iowa. 
17a. Spikelets hairy, variously colored

17b. Spikelets whitish, glabrous. Fig. 54.

Tridens albescens (Vasey) Woot. and Stand.

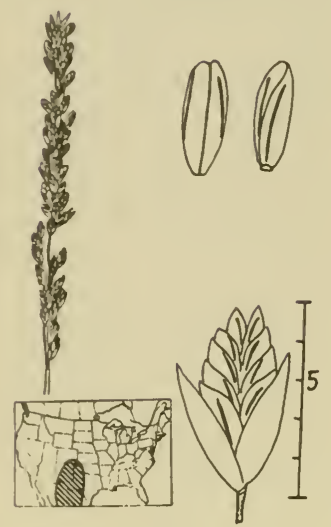

Perennial; tufted or rarely with rhizomes; culms $30-80 \mathrm{~cm}$. tall; panicles spikelike; leaf blades elongated, 2-4 $\mathrm{mm}$. wide, sometimes inrolled. This species may be confused with species of Eragrostis, but the fact that the lemma is split at the tip excludes it from that genus. The plants often grow in draws and around water holes. They are succulent and make good forage, but are seldom found in dense stands. April-October. Also known as Triodia albescens.

Figure 54

18 $\alpha$. Panicle $\alpha$ dense ovoid tuft, $1-3 \mathrm{~cm}$. long, containing usually less than 10 spikelets. Fig. 55.

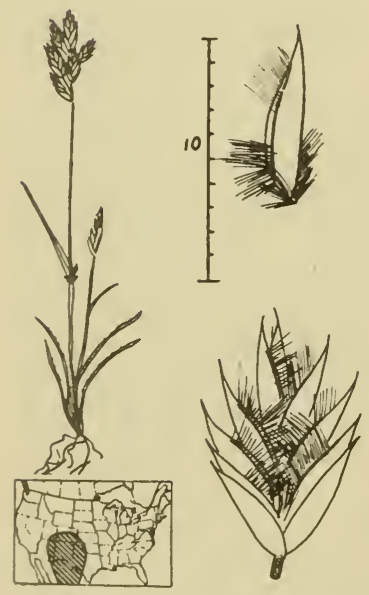

Tridens pilosus (Buckl.) Hitch.

Perennial; tufted; $10-30 \mathrm{~cm}$. tall. Most of the very narrow white-margined leaves are at the base of the plants. The culm usually consists of $a$ single internode. The plants are very shallow rooted and easily pulled up. Found frequently on thin rocky soils and overgrazed ranges of the Southwest. This species has little forage value and is generally regarded as an indicator of overgrazing. March-October. Also known as Triodia pilosa. 
18b. Panicle slender and spikelike, usually 5-15 cm. long, with more than 10 spikelets. Fig. 56.

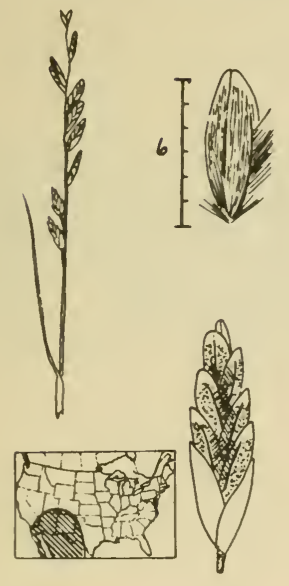

Figure 56

Tüidens muticus (Torr.) Nash

Perennial; tufted; culms $30-50 \mathrm{~cm}$. tall. The spikelets often have a faint purplish hue before drying. Leaf blades very narrow, about $1 \mathrm{~mm}$. wide. Overgrazed lands and dry rocky slopes. Forage value low. JuneOctober. Also known as Triodia mutica.

Tridens elongatus (Buckl.) Nash is very similar, but has leaf blades up to $3-4 \mathrm{~mm}$. wide; plants $40-80 \mathrm{~cm}$. tall; panicles $10-25$ $\mathrm{cm}$. long. Missouri to Texas and Ärizona.

19a. Lemmas split at the tip. Fig. $57 \ldots \ldots \ldots 17 b$

19b. Lemmas not split at the tip............20

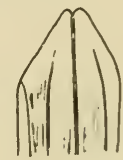

Figure 57

20a. Grain large, bottle-shaped, 5-6 mm. long, forcing the stiff, strongly-keeled lemma and the palea apart at maturity and protruding between them. Fig. 58 .

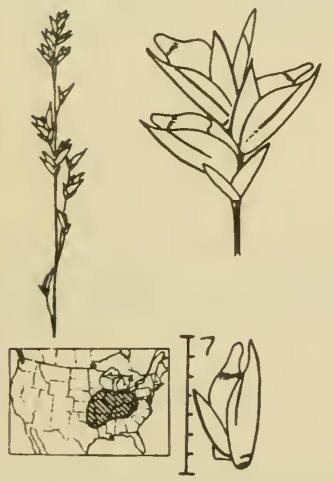

Figure 58
Diarrhena americana Beauv.

Perennial; producing numerous scaly rhizomes; culms up to a meter in height; leaves mostly low on the culm, the blades $1-2 \mathrm{~cm}$. wide, scabrous or hairy; panicle slender, with short erect branches, nodding, $10-30 \mathrm{~cm}$. long. Spikelets $10-18 \mathrm{~mm}$. long. Growing in scattered clumps in rich woods. The peculiarly shaped grains are unique among our grasses. JulyOctober. 
20b. Grain not bottle-shaped nor forcing the floret open; not over $2 \mathrm{~mm}$.

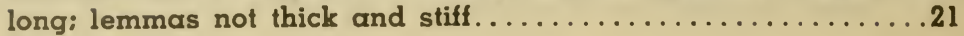

21a. Spikelets with three or more florets; lemmas pointed, the veins converging; plants of wet or dry ground.(NOTE: the Genus Eragrostis, which follows, is a difficult one. No entirely satisfactory key has ever been made for the species found in the U. S. The following keys are compiled from the best available).......22

21b. Spikelets with two florets; lemmas with wide blunt tips and parallel veins; plants aquatic. Fig. 59.

BROOKGRASS

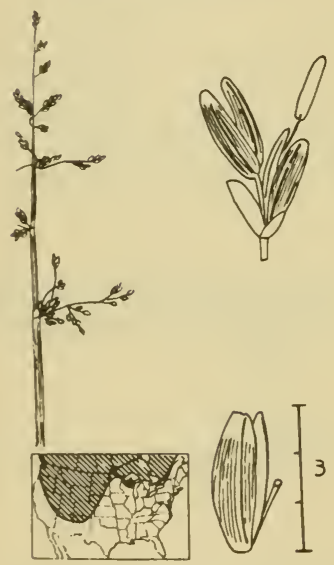

Figure 59

Catabrosa aquatica (L.) Beauv.

Perennial. The culms may lie on the ground and root at the nodes for half or more of their length of $10-50 \mathrm{~cm}$. Panicles yellowish, 10-20 cm. long, open, pyramidal. Brookgrass is a soft, succulent grass of wet ground, found in the sub-arctic and at higher elevations in the western mountains of the United States. The plants make excellent summer feed for livestock. Found also in northern Europe and Âsia. June-August.

22a. Plants forming flat mats, the trailing culms rooting at the nodes . 23

22b. Plants erect or with somewhat decumbent culms, but never rooting at the nodes. 
23a. Staminate and pistillate spikelets on separate plants; anthers about $1.5-2 \mathrm{~mm}$. long; panicle dense. Fig. 60 .

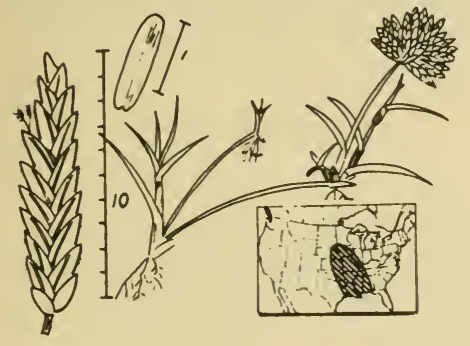

Figure 60
Eragrostis reptans (Michx.) Nees

Annual; stoloniferous; only a few cm. tall, forming delicate, bright green turf along streams and on wet ground. Spikelets borne in dense panicles, resembling clover heads. Lemmas very strongly keeled. While the two sexes are similar in appearance, they can be told apart by the presence of anthers or stigmas protruding from the florets. Late summer and fall. Forage value low.

23b. Spikelets all with perfect flowers; anthers minute, about $0.2 \mathrm{~mm}$. long. Fig. 61.

Eragrostis hypnoides (Lam.) B.S.P.

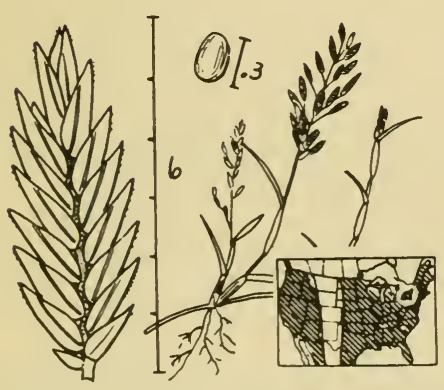

Figure 61

Annual; stoloniferous, forming low mats. The panicle is usually open. Lemmas very strongly keeled. The anthers are minute and nearly round, with a bulk of less than 1/50 that of those of $E$. reptans. Like most of its relatives, this plant is a warm weather grass, growing rapidly from midsummer on. Stream banks and wet ground. Forage value low. July-September.

24a. Lemmas when mature dropping from the persistent rachilla of the spikelet; (this can be detected by pulling lemmas outward and downward) paleas usually remaining on the rachilla........36

24b. Lemmas not falling separately; spikelets disarticulating between

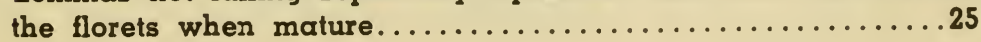


25b. Paleas fringed with long straight hairs which nearly cover the spikelets. Fig. 62.
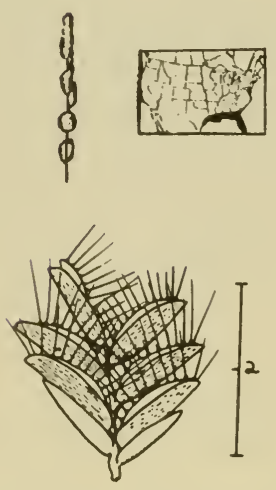

Eragrostis ciliaris (L.) R. Br.

This delicate tufted annual grass grows $15-30 \mathrm{~cm}$. tall, and bears dense cylindrical panicles, like those of the foxtail grasses, 3$10 \mathrm{~cm}$. long. The tiny spikelets, only $2-4$ $\mathrm{mm}$. long, are immediately identifiable by the long, fringe-like cilia borne on the margins of the palea, which give a sort of spider-web appearance to the spikelets. River banks and open ground. Widespread in warm regions of the world. June-August.

Figure 62

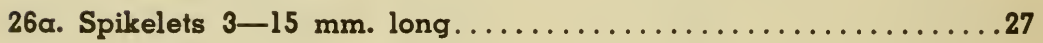

26b. Spikelets 2-3 mm. long; panicle elongated, dense, narrowly cylindrical. Fig. 63.

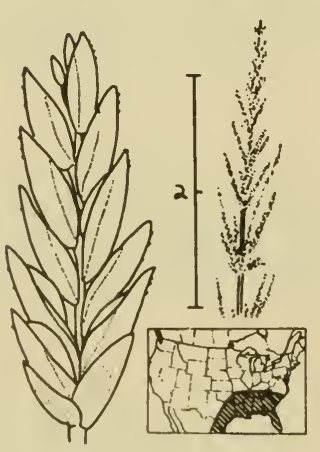

Figure 63

Eragrostis glomerata (Walt.) Dewey

Annual; tufted; plants a meter or less in height. $E$. glomerata produces a profusion of slender, cylindrical panicles up to $50 \mathrm{~cm}$. long, with strongly ascending branches. The plants flower from near ground level to the very tip. The tiny spikelets have very thin, translucent lemmas. At maturity the grains are visible through the lemmas. Banks of streams and ditches, alluvial woods. July-November. 
27a. Spikelets sessile or nearly so, strongly keeled and flattened...28

27b. Spikelets on slender pedicels; lemmas keeled or rounded on the

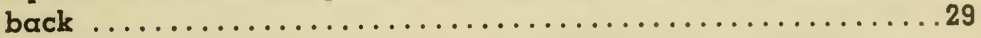

28a. Spikelets few, distant along the few elongated panicle branches, a sessile spikelet and a cottony tuft of hairs in the axil of each panicle branch. Fig. 64.

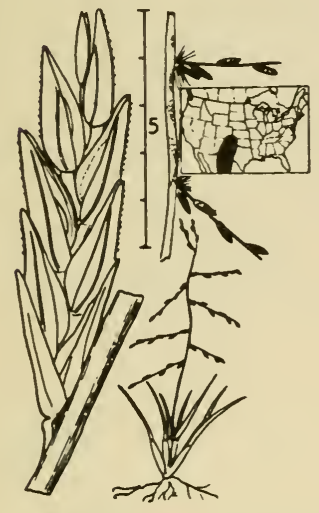

Figure 64

Eragrostis sessilispica Buckl.

Perennial; tufted; plants usually 20-40 $\mathrm{cm}$. tall. This is a tumbleweed grass, the panicle breaking off and rolling with the wind when mature. The leaves are clustered in a short basal tuft. The panicle may reach as much as $40 \mathrm{~cm}$. in length. The main axis is somewhat spiral; the branches are straight, stiff, and bear sessile spikelets. Dry sandy plains. Forage value apparently low. May-June.

28b. Spikelets numerous, in a dense panicle; no sessile spikelets and cottony tufts in the axils. Fig. 65.

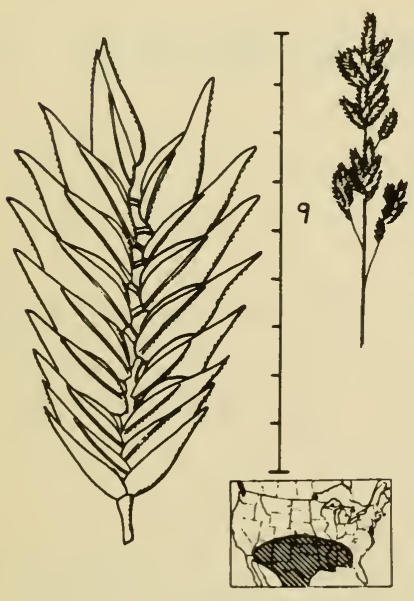

Figure 65

Eragrostis oxylepis Torr.

Perennial; wiry; tufted; plants 20 $-70 \mathrm{~cm}$. tall; leaves $1-5 \mathrm{~mm}$. wide, smooth except at the base of the blade. The spikelets are borne in one or more dense tufts along the axis or branches of the panicle. The spikelets often overlap like shingles. They usually have a reddish or bronzy color when ripe. Sandy or rocky open ground. Forage value apparently low. July-October. Also called $E$. secundiflora.

Eragrostis beyrichii J. G. Smith is similar, but the spikelets are pale instead of bronzy. Oklahoma to Mexico. 
29a. Panicle branches stiffly spreading; spikelets deep reddish purple; lemmas strongly keeled. Fig. 66.

\section{PURPLE LOVEGRASS}

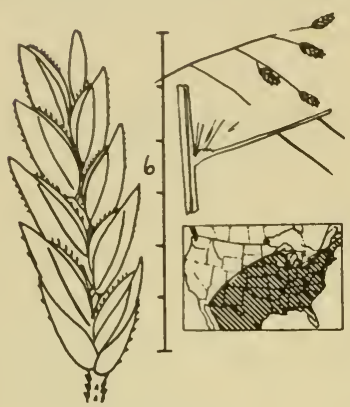

Figure 66
Eragrostis spectabilis (Pursh) Steud.

Perennial; tufted; erect or rarely spreading, up to $60 \mathrm{~cm}$. tall. Purple lovegrass has a large, open, domeshaped panicle which makes up about two-thirds of the height of the plant. The axils of the panicle branches and throats of the sheaths bear conspicuous tufts of white hair. The leaf sheaths may be smooth or hairy. This is one of our most widespread grasses on sandy open ground, and one of the most attractive. July-September.

29b. Panicle branches delicate, not stiffly spreading; lemmas not strong-

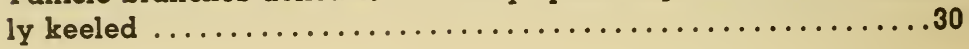

$30 a$ Sheaths glabrous, or pubescent on only the upper edges.....31

30b. Sheaths pubescent along the edges, on the surface, and on the

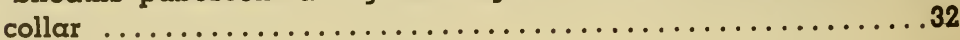

3la. Lemmas $1.8-2.4 \mathrm{~mm}$. long; panicle broad, ovoid..........35 
31b. Lemmas $2.4-3.4 \mathrm{~mm}$. long; spikelets $4 \mathrm{~mm}$. or more long: panicle elongated, ellipsoid. Fig. 67.

SAND LOVEGRASS

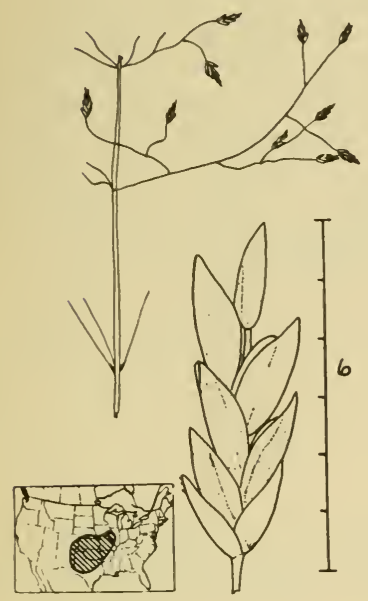

Eragrostis trichodes (Nutt.) Wood

Perennial; tufted; 80-120 cm. tall. The open, cylindrical panicles may make up half the total height of the plant. The spikelets frequently have purplish florets and yellow glumes. Sandy plains and open woodlands. Sand lovegrass has high forage value, but has been virtually destroyed by overgrazing in many of the areas where it once abounded. August-September.

Eragrostis curvula (see Fig. 69) sometimes has smooth sheaths and might be keyed out here. It may be recognized by the lead-colored, short-pedicellate spikelets.

Figure 67

32a. Sheaths and often blades bearing hairs, each of which arises from $\alpha$ little blister. Fig. 68...33

32b. Hairs of sheaths not arising from little blisters .34

33a. Spikelets 5-10 $\mathrm{mm}$. long: lemmas $2.4-3.4 \mathrm{~mm}$.

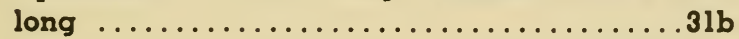

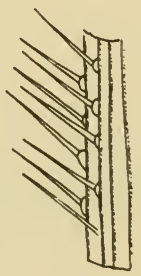

Figure 68

33b. Spikelets $2-5 \mathrm{~mm}$. long; lemmas $2.0-2.4 \mathrm{~mm}$. long.........35

34a. Panicle not over twice as long as wide; usually $15 \mathrm{~cm}$. wide or wider 
34b. Panicle 3 times as long as wide; never over $12 \mathrm{~cm}$. wide; cultivated and sometimes escaping. Fig. 69.

WEEPING LOVEGRASS

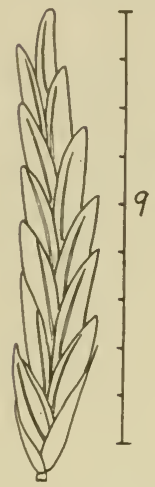

Figure 69

Eragrostis curvula (Schrad.) Nees

Perennial; tufted; $60-120 \mathrm{~cm}$. tall, forming large round clumps. The leaves are long, drawn out to very fine drooping tips. The panicles are elongated and somewhat drooping; branches not bearing spikelets near the bases; spikelets dull straw colored or leaden gray. Native to South Africa, weeping lovegrass was first brought to the United States as an ornamental, but is now widely planted in the southern states as a forage grass for revegetating abandoned or eroded crop land. It makes excellent pasturage and can be used for hay. The seeds are about $1 \mathrm{~mm}$. long, smooth, amber colored except for the blackish germ. Summer.

Eragrostis trichodes (Fig. 67) sometimes has hairy sheaths and may key out here. It may be recognized by the long-pedicellate, usually bronzy or yellowish spikelets.

35a. Lemmas 2.0-2.4 mm. long: larger leaf blades 5-10 mm. wide. Fig. 70.

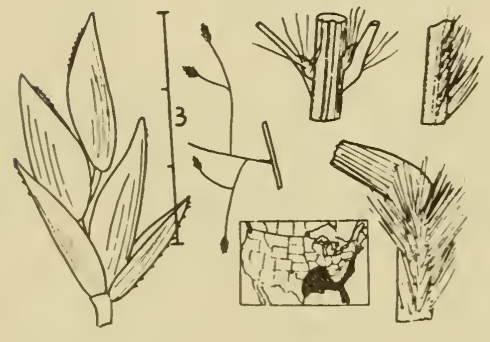

Figure 70
Eragrostis hirsuta (Michx.) Nees

Perennial; tufted; plants becoming a meter or more tall; panicles large, open, cylindrical, half the height of the plant. The leaves are wider than in most other species of this genus and taper to long fine points. The summits of the leaf sheaths (see figure) vary from extremely hairy to glabrous. Dry soil, in open woods and fields. Summer. 
35b. Lemmas 1.8-2.2 $\mathrm{mm}$. long; larger leaf blades $2-3 \mathrm{~mm}$. wide. Fig. 71.

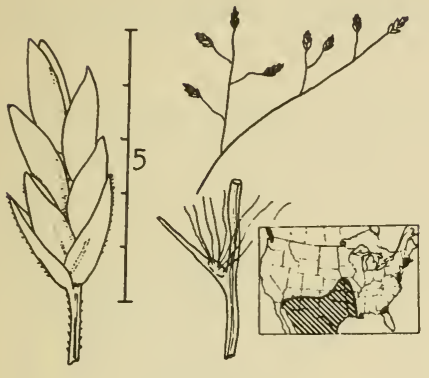

Figure 71

Eragrostis intermedia Hitch.

Perennial; tufted; reaching nearly a meter in height. This species has an open, dome-shaped panicle with slender delicate branchlets. The leaf blades are narrow, involute, and drawn out to slender tips; sheaths glabrous or the lower ones somewhat hairy. Dry sandy open ground. June-September.

$36 a$. Plants perennial, usually $50-150 \mathrm{~cm}$. tall, forming large clumps from hard, knotty bases; basal buds of next years growth present at flowering time................ go back to .......27

36b. Plants annual, usually less than $50 \mathrm{~cm}$. tall, from soft, shallowrooted bases; no basal buds present at flowering time.......37

37a. Spikelets with $2-4$ (rarely 5 ) florets.................

37b. Spikelets with 6-many florets (rarely 5 in starved plants)...39 
38a. Pedicels of lateral spikelets 3-many times as long as the spikelets; panicle large, diffuse, $2 / 3$ or more of the total height of the plant; plants erect. Fig. 72.

\section{LACEGRASS}

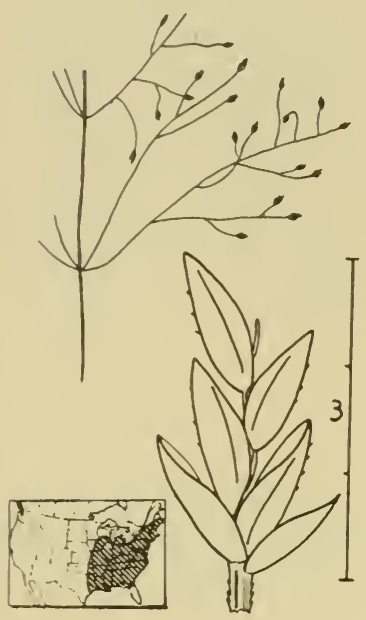

Eragrostis capillaris (L.) Nees

Lacegrass is a densely tufted annual, up to $50 \mathrm{~cm}$. in height. Culms much branched at the base, the plants bearing numerous panicles; leaf sheaths somewhat hairy, especially at the throat; blades flat, hairy on the upper surface, $1-3 \mathrm{~mm}$. wide; panicles opencylindrical or elliptical, making up most of the height of the plants. Spikelets 2-3 mm. long, with 2-4 florets; glumes about $1 \mathrm{~mm}$. long; lemmas about 1.5 $\mathrm{mm}$. long. The minute grains are about $0.5 \mathrm{~mm}$. long. Lacegrass is a common weed of open, dry situations on waste ground, in fields, and thin woods. August-September.

Figure 72

38b. Pedicels of lateral spikelets short, rarely more than twice the length of the spikelets; panicles about half the length of the sprawling plants. Fig. 73.

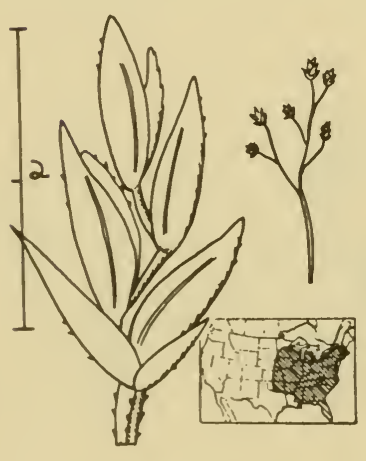

Figure 73
Eragrostis trankii C. A. Mey.

Annual. $\bar{A}$ weed of river banks and wet alluvial bottoms, $E$. frankii makes sprawling bushy tufts. The culms are seldom more than $25 \mathrm{~cm}$. long. Leaf sheaths and blades usually smooth except at the throat. The ellipsoidal panicle is much denser than that of $E$. capillaris, because of the shorter pedicels. August-September. 
39a. Plants without glands on spikelets or branches; spikelets $2 \mathrm{~mm}$.

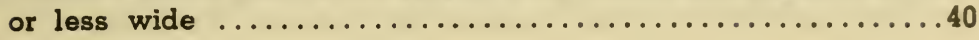

39b. Plants bearing minute blister-like glands on the keels of the glumes and lemmas and the branches of the panicle; spikelets 2.5-3.5 mm. wide when mature. Fig. 74.

\section{STINRGRASS}

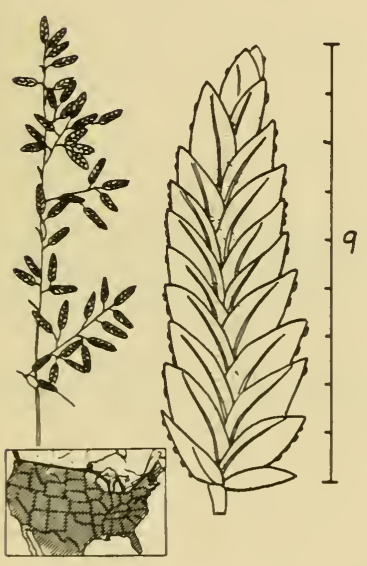

Figure 74
Eragrostis cilianensis (All.) Link

Annual; tufted; culms erect or somewhat spreading; panicles ovoid or pyramidal, rather dense. The keels of the glumes and lemmas bear tiny circular glands. Stinkgrass is a vigorous weedy annual, with a strong, musty odor when fresh. It may be poisonous to horses if eaten in large quantities. Frequent in fields, gardens, and dry, disturbed soil. Introduced from Europe and now very common throughout the United States. June-October. Also known as E. megastachya.

A very similar species, $E$. poaeoides Beauv., has spikelets with glands on the keels of the lemmas also. The spikelets range from $1.3-2.0 \mathrm{~mm}$. wide. It is less common than stinkgrass. Introduced from Europe.

40a. Sheaths bearing a few long hairs on the margins at their summits; paleas remaining on the rachilla................. 
40b. Upper sheaths (and usually the lower ones as well) lacking long hairs at their summits; panicle rather dense, the lower branches usually single, bearing 11-40 spikelets: paleas falling from the rachilla with the lemmas. Fig. 75.

Eragrostis multicaulis Steud.

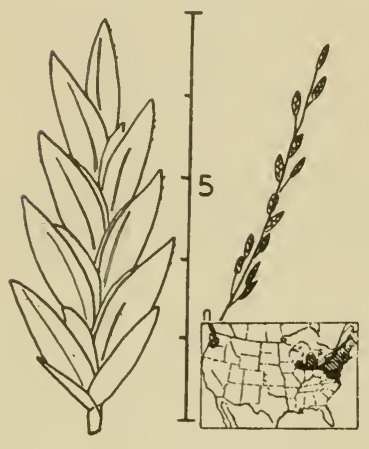

Figure 75
Weedy, tufted, annual, usually under $30 \mathrm{~cm}$. tall. Spikelets $3-4 \mathrm{~mm}$. long, usually with 4-8 florets. After the paleas fall, the minute zig-zag rachillas remain as the only evidence of the spikelets. This species grows mostly as a weed in cities in the northeastern states. Although introduced in the Americas, its homeland is not known with certainty. July-October. Also known as E. peregrina.

4la. Spikelets mostly lying closely appressed to the panicle branches. Fig. 76.

Eragrostis pectinacea (Michx.) Nees

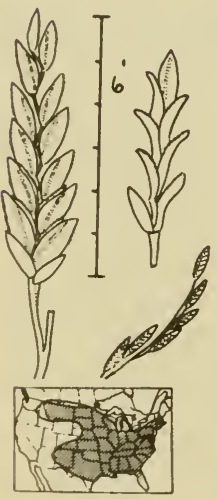

Weedy annual; tufted; culms usually 20-30 $\mathrm{cm}$. tall; plants branching freely from the base, forming dense, erect tufts. Spikelets 5-8 $\mathrm{mm}$. long. The manner in which the spikelets lie parallel to the panicle branches is characteristic. Frequent on dry roadsides, waste ground, and cultivated fields; one of the commonest weedy annual grasses. July-October. 
$41 \mathrm{~b}$. Sp.kelets when mature diverging strongly from the panicle branches; spikelets $0.7-1.4 \mathrm{~mm}$. wide; lateral nerves of lemmas obscure. F.g. 77.

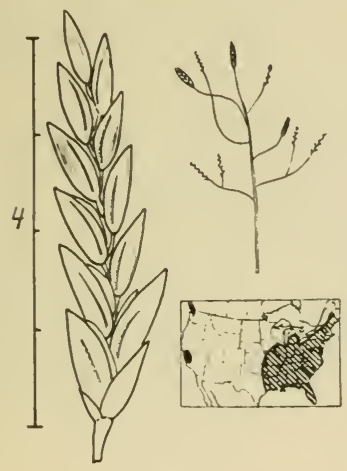

Figure 77

Eragrostis pilosa (L.) Beauv.

Annual; tufted; delicate; culms 10-50 $\mathrm{cm}$. tall; panicles open, ellipsoidal. The tiny spikelets, $3-5 \mathrm{~mm}$. long, stand out away from the main panicle branches on hair-like pedicels. Leaf blades $1-3$ $\mathrm{mm}$. wide, flat. Introduced from Europe. July-September.

42a. Spikelets very strongly laterally ccmpressed, the lemmas keeled

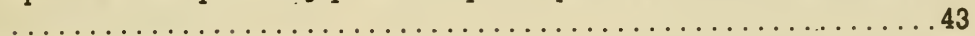

42b. Spikelets not strongly compressed, the lemmas rounded on the back .................................. 47

43a. Spikelets with $1-5$ empty lemmas below the fertile ones; panicles drooping; spikelets large, $2-4 \mathrm{~cm}$. long..............44

43b. Spikelets without empty lemmas below the fertile ones; spikelets

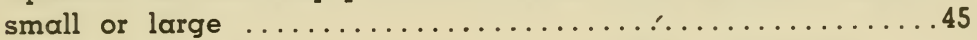

44a. Spikelets with 4-5 empty lemmas; leaf blades thick and involute, less than $1 \mathrm{~cm}$. wide. Fig. 78.

SEA OATS

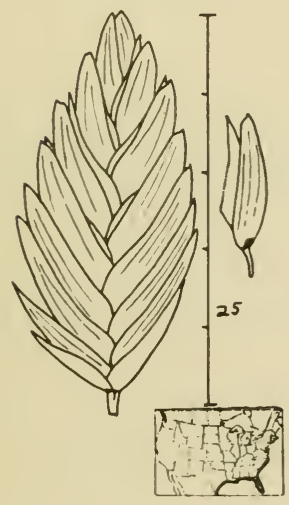

Uniola paniculata L.

Figure 78

Perennial, producing strong rhizomes; plants up to $1 \mathrm{~m}$. tall; panicles dense, nodding, 20$40 \mathrm{~cm}$. long. The very flat spikelets of the Uniolas are strikingly ornamental. Sea oats inhabits the coastal sand dunes along the Atlantic and Gulf of Mexico and the West Indies. The panicles are frequently harvested and used for winter bouquets and displaywindow ornaments. Spikelets may be found on the plants at most seasons of the year. 
44b. Spikelets with 1 empiy lemma; leaf blades thin and flat, mostly $1-2 \mathrm{~cm}$. wide. Fig. 79.

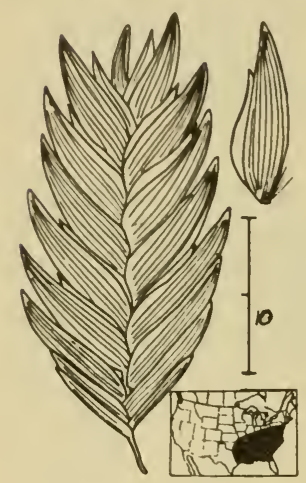

Figure 79

Uniola latifolia Michx.

Perennial; producing rhizomes; plants $1-1.4$ $\mathrm{m}$. tall; panicles open and drooping, 10-20 $\mathrm{cm}$. long. While similar to sea oats, this is a woodland species of rich soil in the southeastern United States. It is highly ornamental and suitable for growing in shaded borders or wild gardens. Several other species of this genus with smaller spikelets also occur in the southeastern states. June-October.

45a. Spikelets $2-4 \mathrm{~cm}$. long, in open panicles; lemmas awned or awבtipped between 2 teeth or below the apex.............77

45b. Spikelets usually $1 \mathrm{~cm}$. or less long; lemmas awnless or tapering

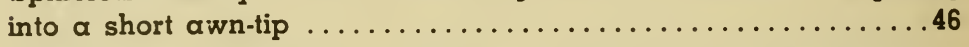

46a. Spikelets on pedicels, in open or contracted panicles; lemmas awnless: glumes not ciliate ....................... 104

46b. Spikelets nearly sessile, in dense, one-sided tufts at the ends of the few, long, stiff, panicle branches; glumes and lemmas ciliate on the keels; lemmas pointed or short-awned. Fig. 80.

\section{ORCHARD GRASS}

Dactylis glomerata. L.

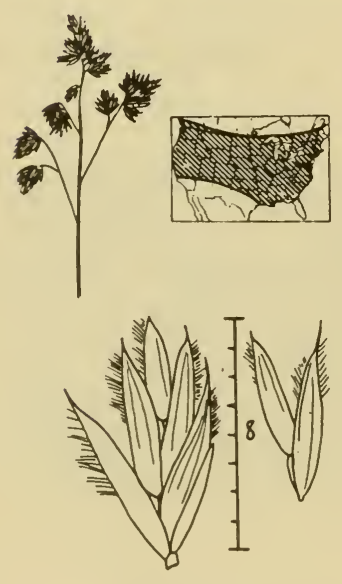

Perennial; tufted; plants $60-120 \mathrm{~cm}$. tall; herbage light green; leaf blades 2-8 $\mathrm{mm}$. wide. The panicle branches spread only at flowering time. The plants grow in large tussocks. They furnish both pasturage and hay, and this species is rather important as a forage grass. It will tolerate partial shade. Introduced from Europe. May-July.

Figure 80 
47a. Lemmas longer than wide, their margins curled or folded in over the edges of the palea; florets making acute angles with the

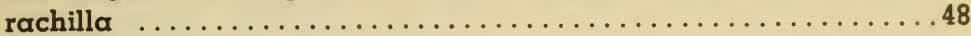

47b. Lemmas nearly circular in outline, their margins not curled in: florets and glumes spreading at right angles to the rachilla. Fig. 81.

QUAKING GRASS

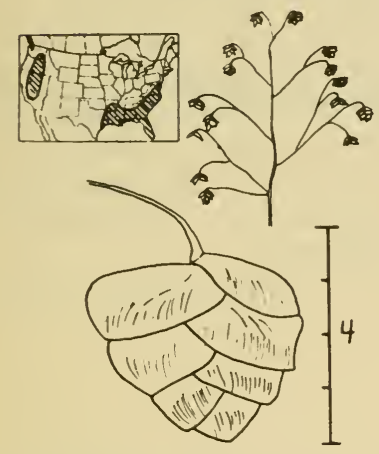

Figure 81

Briza minor L.

Annual; tufted; $10-40 \mathrm{~cm}$. tall. The species of Briza have very slender pedicels, which allow the drooping spikelets to quiver in any slight breeze. Ligules $4-5 \mathrm{~mm}$. long. This species and the next are occasionally grown for ornament and winter bouquets. April -May. Introduced from Europe.

Briza media L. is similar, but has larger spikelets. The ligules are about 1.5 mm. long. New England to Michigan. Introduced from Europe.

48a. Callus of the florets covered with prominent straight or cottony hairs

48b. Callus of the florets glabrous...................

49a. Callus hairy with straight spreading or erect hairs; lemmas awned or awnless. Fig. $82 \ldots 50$

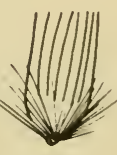

Figure 82

49b. Callus hairy with fine, crimped cottony hairs; lemmas awnless. Fig. $83 \ldots \ldots \ldots \ldots \ldots 104$

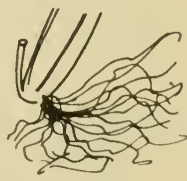


50a. Lemmas irregularly toothed and cut at the apex; plants of wet ground or water. Fig. 84.

Scholochloa festucacea (Willd.) Link
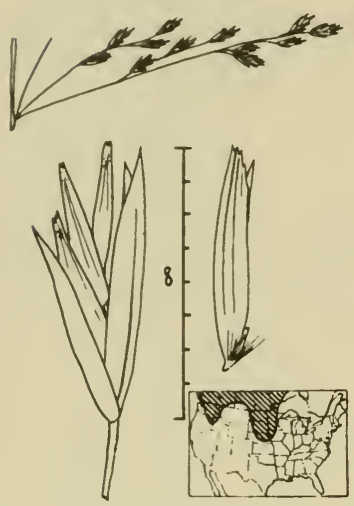

Perennial; spreading by thick, elongated rhizomes; plants $1-1.5 \mathrm{~m}$. tall; panicles open, $15-20 \mathrm{~cm}$. long; leaf blades usually $5-10 \mathrm{~mm}$. wide. This species is a plant of marshes and stream borders, where it often forms large colonies along with sedges, rushes, and other kinds of aquatic grasses. Late June and early July. Furnishes some forage and marsh hay. Also known as Fluminea festucacea.

Figure 84

50b. Lemmas awned between 2 teeth; plants of rocky woods. Fig. 85 .

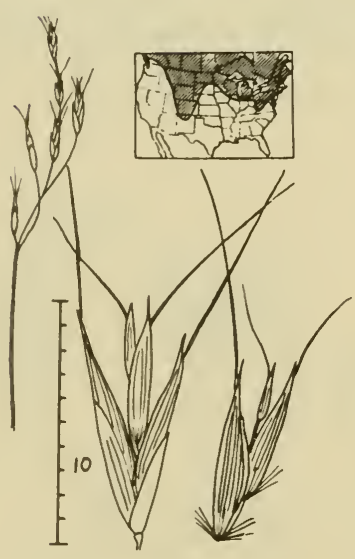

Figure 85
Schizachne purpurascens (Torr.) Swallen

Perennial; tufted; $50-100 \mathrm{~cm}$. tall; sheaths with united edges; leaf blades narrowed at the base, $1-5 \mathrm{~mm}$. wide; panicles about $10 \mathrm{~cm}$. long, drooping. The glumes of the spikelets are usually purple. This is a rather delicate grass of rocky woodlands. It grows in scattered clumps and is seldom numerous. May-July. Also found in Japan and Siberia.

5la. Upper florets of the spikelets sterile, often wrapped around each other and forming a club- or bell-shaped structure; (CARE!) sheaths with united edges; disarticulation above or below the glumes...52 
5lb. Upper florets fertile, the lemmas not enwrapping each other: sheaths with overlapping or united edges; spikelets disarticulat-

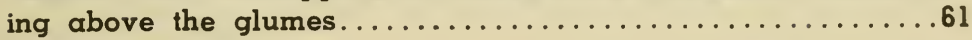

52a. Spikelets disarticulating below the glumes and falling entire at

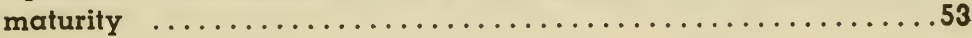

52b. Spikelets disarticulating above the glumes and between the flor-

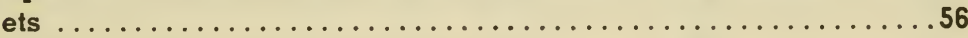

53a. Rudimentary lemmas forming a pointed, cigar-shaped structure

53b. Rudimentary lemmas forming a blunt, club-shaped or bell-shaped structure

54a. Glumes reaching nearly to the tip of the spikelet; spikelets V. shaped. Fig. 86.

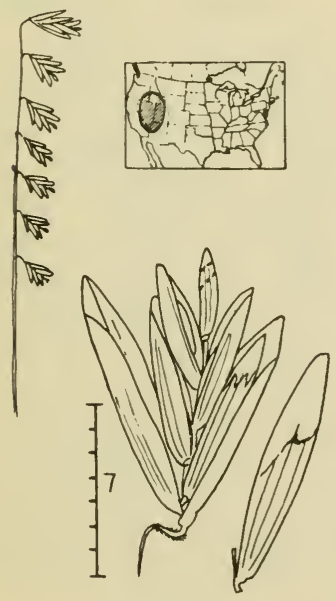

Melica stricta Bolander

Figure 86

Perennial; tufted; plants $15-60 \mathrm{~cm}$. tall; panicle slender, almost unbranched, raceme-like. All of the species of Melica have thin, translucent glumes and firmer lemmas. In this species, the glumes frequently have considerable purple coloration. Leaf blades scabrous, hairy on the top, 1-3 mm. wide. Rocky and gravelly slopes in the mountains. Late MayAugust. 
54b. Glumes less than $2 / 3$ as long as the entire spikelet; spikelets narrow, cylindrical. Fig. 87.

Melica porteri Scribn.

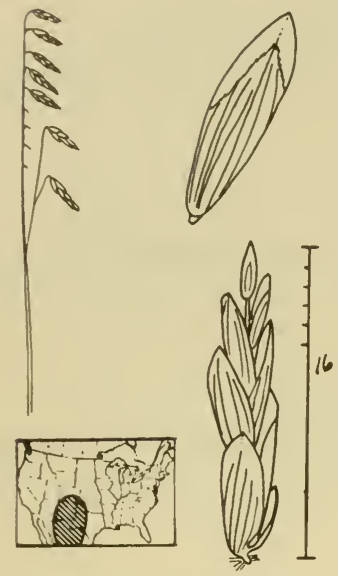

Figure 87

Perennial; tufted; $50-100 \mathrm{~cm}$. tall; inflorescences slender and raceme-like, 15 $-20 \mathrm{~cm}$. long, the branches ascending; spikelets mostly drooping to one side; pedicels hairy; sheaths smooth or scabrous, with united edges; leaf blades 2-5 $\mathrm{mm}$. wide; spikelets green or brownish, not purple, 10-15 mm. long, with 4-5 florets; lemmas strongly-nerved, minutely scabrous. Open woods and slopes, moist ground; $2000-3000 \mathrm{~m}$. elevation. Midsummer-October.

Var. laxa Boyle has spreading panicle branches 4-9 cm. long; glumes sometimes purple. Western Texas (Chisos Mts.) to Arizona.

55a. Rudiment placed obliquely at the end of the rachilla; tips of fertile florets at the same height. Fig. 88.

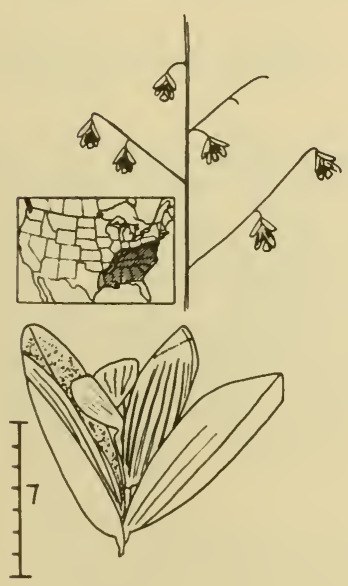

Figure 88

Melica mutica Walt.

Perennial; tufted; plants $60-100 \mathrm{~cm}$. tall; panicles $10-20 \mathrm{~cm}$. long, with a few simple spreading branches bearing drooping spikelets. Sheaths hairy or scabrous; leaf blades $2-5 \mathrm{~mm}$. wide. Spikelets fan-shaped, 7-10 $\mathrm{mm}$. long, usually with 2 fertile florets and a bellshaped rudiment, tilted sideways, at the end of the rachilla. This species, while seldom occurring in large stands, is the most widespread of the eastern Melica species. It grows in scattered stands in rocky woods. April-June. The name Melica refers to honey, but we do not know why Linnaeus applied it to this genus. 
55b. Rudiment placed straight on the end of the rachilla; tips of lower florets below that of the uppermost one. Fig. 89.

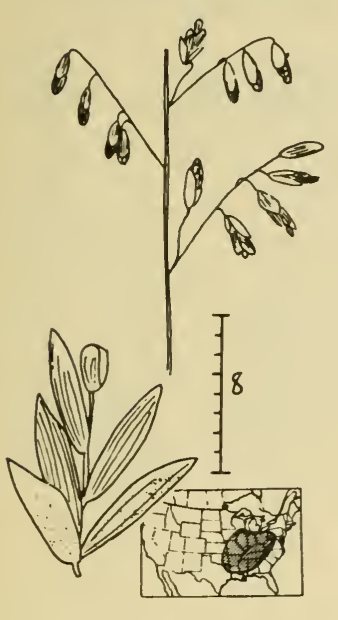

Figure 89

Melica nitens (Scribn.) Hitch.

Perennial; tufted; plants $50-120 \mathrm{~cm}$. tall; leaf sheaths glabrous or scabrous; leaf blades 7-15 $\mathrm{mm}$. wide; panicles $10-20$ $\mathrm{cm}$. long, with a few branches. The drooping spikelets are more slender than in the previous species and usually have 3 fertile florets. The rudiment is more slender and pointed than in Melica mutica. This species is probably more common than the previous one. The two are frequently confused but the position and shape of the rudiment should distinguish them. Scattered in rocky woods. Late April-June.

56a. Lemmas without 57

56b. Lemmas bearing awns. Fig. 90 .

Melica smithii (Porter) Vasey

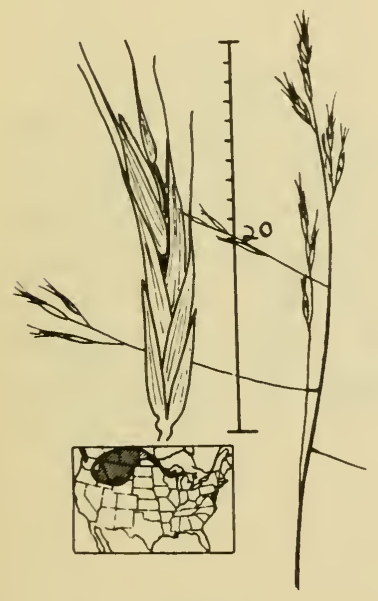

Figure 90

Slender tufted perennial; plants 60$120 \mathrm{~cm}$. tall; sheaths downwardly scabrous; leaf blades soft, scabrous, 6-12 $\mathrm{mm}$. wide. The panicles are very open, $12-25 \mathrm{~cm}$. long, with slender spreading branches bearing spikelets at the tips. The spikelets are $18-20 \mathrm{~mm}$. long, with 3-6 florets, and sometimes are purplish; awns are $3-5 \mathrm{~mm}$. long. This slender woodland grass is found in moist forests. The occurrence in northern Michigan is the result of the cold postglacial climate which once embraced that area. The plants resemble those of some of the perennial species of Bromus, from which they differ in the presence of the rudiment. July-August. 
$57 a$. Culms with bulbs at the bases..................... 58

57b. Culms without bulbs at the bases.................60

$58 \alpha$. Lemmas acute or obtuse, glabrous...................59

58b. Lemmas tapering to an acuminate tip, pubescent. Fig. 91.

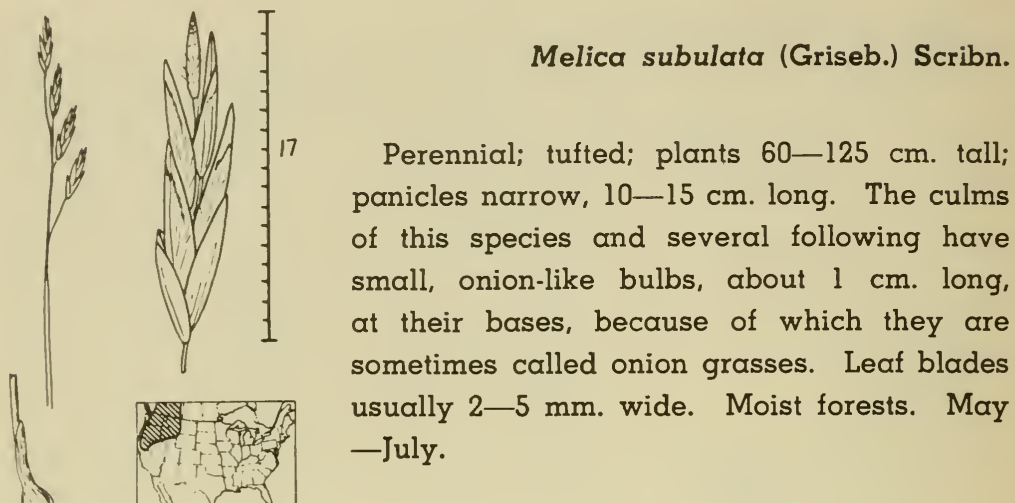

Figure 91

59a. First glume less than half as long as the spikelet; bulb attached to the crown of the plant by a thin stalk as much as $1 \mathrm{~cm}$. long. Fig. 92.

\section{ONIONGRASS}

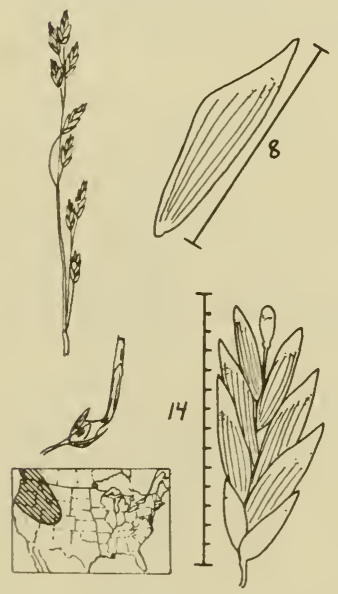

Melica spectabilis Scribn.

Figure 92

Perennial; plants $30-100 \mathrm{~cm}$. tall; panicle slender, $10-15 \mathrm{~cm}$. long. This is a handsome species with somewhat inflated spikelets, the lemmas purple-tipped. Leaf sheaths hairy; blades flat or rolled, 2-4 mm. wide. Gravelly mountain meadows and slopes. July-August. Forage value good. 
59b. First glume more than half as long as the spikelet; bulbs attached directly to a thick knotty crown. Fig. 93.

ONIONGRASS

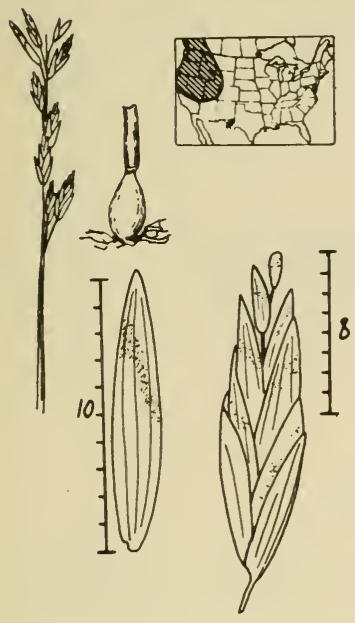

Figure 93
Melica bulbosa Geyer

Perennial; plants $30-60 \mathrm{~cm}$. tall; panicle narrow and stiff. Leaf sheaths and blades smooth or hairy; blades $2-4 \mathrm{~mm}$. wide. This is perhaps the commonest western species in the genus. As the name implies, the plants usually have prominent bulbs at the bases of the culms. Woods and open slopes. July -August. Forage value good.

Melica fugax Boland. differs from the above species in having soft, thickish rachilla joints which turn tan and wrinkle when dried. The rachilla of $M$. bulbosa is thin, smooth, and white. Panicles $8-15 \mathrm{~cm}$. long, with short spreading or drooping branches. Dry ground, Washington to northern California and Nevada. Good forage for livestock and wild grazing animals. May-June.

$60 a$. Spikelets with 3 or more fertile florets.....go back to $59 b$.

60b. Spikelets with 1 or 2 fertile florets. Fig. 94.

Melica imperfecta Trin.
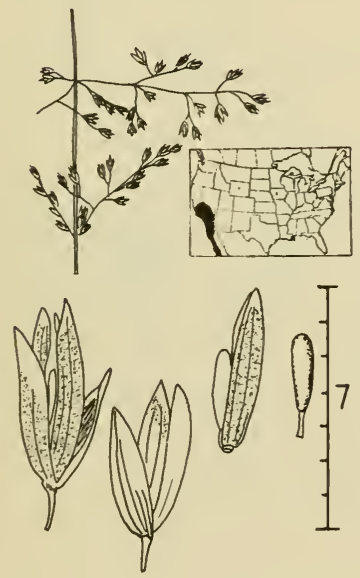

Perennial; tufted or with decumbent culms; plants $25-80 \mathrm{~cm}$. tall, bearing spreading panicles, $5-30 \mathrm{~cm}$. long, of numerous small, often purplish spikelets. In addition to the 1 or 2 fertile florets, there is a slender, yellowish rudiment which is $3-4$ times as long as the very short rachilla joint which bears it. Gravelly soil. Good to excellent forage. April-May. 
6la. Nerves of lemmas running parallel to the tip, not meeting at the tip; lemmas usually rather broad; awnless. Fig. 95

61b. Nerves of lemmas converging at the acute apex; lemmas awnless or awned. Fig. 96.......75

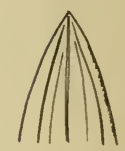

Figure 96

$62 a$. Leaf sheaths with united edges.................63

62b. Leaf sheaths with free, overlapping edges............

63a. Spikelets linear, usually $1 \mathrm{~cm}$. or more long, round in cross section, on short pedicels in narrow, erect panicles.........64

63b. Spikelets ovate or oblong, flattened, $7 \mathrm{~mm}$. or less long; panicles with drooping or erect branches.................... 66

64a. Lemmas obtuse; palea scarcely longer than the lemma......65

64b. Lemmas acute, the palea much longer than the lemma. Fig. 97.

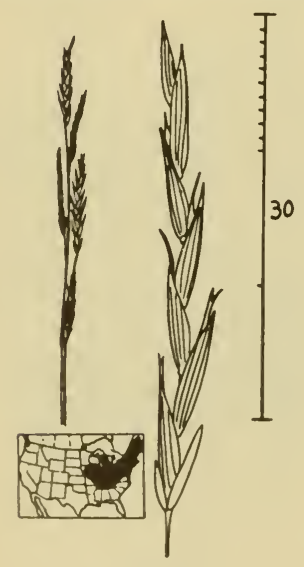

Glyceria acutiflora Torr.

Perennial; rhizome-bearing; plants 50-100 $\mathrm{cm}$. tall; panicles slender, $15-36 \mathrm{~cm}$. long. Wet soil, swamps, or shallow water. MayAugust. The species of Glyceria all live in wet places, frequently in very shallow water. Their spikelets are very fragile and break up at a touch when ripe. The plants are succulent and make good forage.

Figure 97 
65a. Lemmas $2.5-4 \mathrm{~mm}$. long, glabrous between the scabrous nerves. Fig. 98.

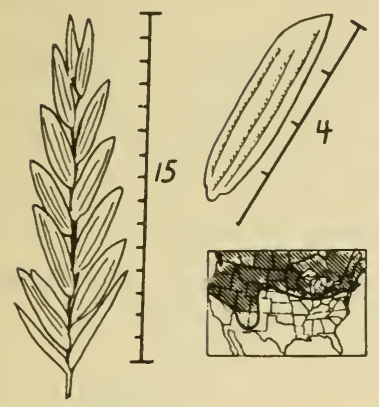

Figure 98

Glyceria borealis (Nash) Batch.

Perennial; culms erect or decumbent; plants $60-100 \mathrm{~cm}$. tall; panicles slender, erect, $20-40 \mathrm{~cm}$. long; leaf blades 2-6 $\mathrm{mm}$. wide; spikelets with 6-12 florets, $1-1.5 \mathrm{~cm}$. long. The inflorescence of this species is similar to that of the next (Fig. 99). Shallow water and marshy shores. June-September. This and the next species are very similar. The seeds of their close relatives in Europe are harvested from the water surface for human food.

65b. Lemmas $4-5.5 \mathrm{~mm}$. long, minutely scabrous between the nerves. Fig. 99.

Glyceria septentrionalis Hitch.

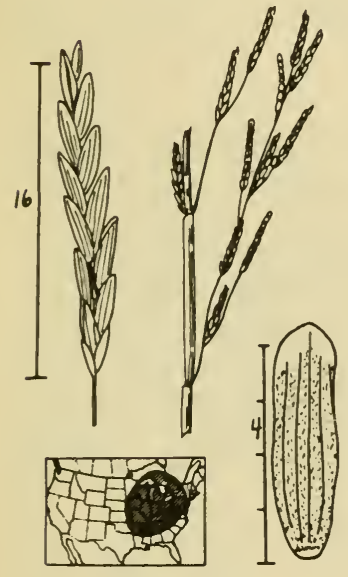

Figure 99

Perennial; culms spongy, $1-1.5 \mathrm{~m}$. tall, erect; panicles $20-40 \mathrm{~cm}$. long, with ascending branches; leaf blades $10-20 \mathrm{~cm}$. long, $4-8 \mathrm{~mm}$. wide; foliage smooth or the leaf blades minutely scabrous; spikelets $1-2 \mathrm{~cm}$. long, cylindrical, with 6-12 florets; lemmas about $4 \mathrm{~mm}$. long. This is a tall, succulent grass of shallow water and wet places, probably yielding good forage. May-July.

Glyceria fluitans (L.) R. Br. resembles the above but has lemmas 5-6 $\mathrm{mm}$. long, usually purple below the tip. Newfoundland to New York; South Dakota; Eurasia. In eastern Europe, the florets and grains of this species are harvested from the water surface for human food, being made into soup and gruel.

66a. Panicle narrow, erect, the branches strongly ascending.....67

66b. Panicle open, the branches drooping or spreading.......68 


\section{HOW TO KNOW THE GRASSES}

67a. Lemmas about $3.5 \mathrm{~mm}$. long; panicle dense, oblong, about $15 \mathrm{~cm}$. or less long. Fig. 100.

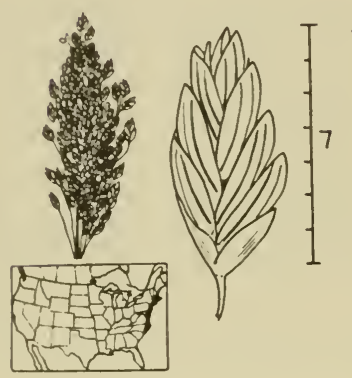

Figure 100

Glyceria obtusa (Muhl.) Trin.

Perennial; culms erect or decumbent, $50-100 \mathrm{~cm}$. tall; leaf blades flat or folded; $2-6 \mathrm{~mm}$. wide; spikelets with $4-7$ florets, 4-7 mm. long. Glyceria obtusa is a characteristic grass of the bogs of the Atlantic Coastal Plain, and found nowhere else. August-September.

67b. Lemmas $2.0-2.7 \mathrm{~mm}$. long; panicle slender, $15-36 \mathrm{~cm}$. long. Fig. 101.

Glyceria melicaria (Michx.) F. T. Hubb.
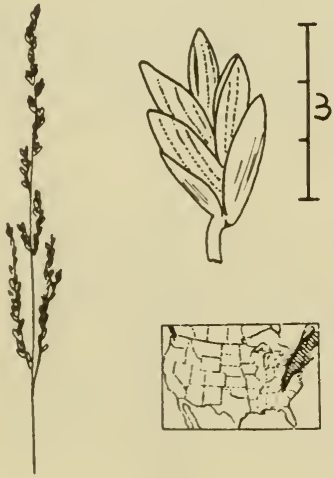

Perennial; culms in small tufts, 60$100 \mathrm{~cm}$. tall; leaf blades long and narrow, rough, 2-5 mm. wide; spikelets with 3-4 florets, about $4 \mathrm{~mm}$. long. The slender, arching culms of this species fringe woodland streams and puddles.

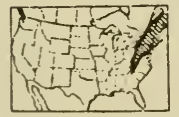
July-August.

Figure 101

68a. Spikelets oblong or ovate, mostly less than $2 \mathrm{~mm}$. wide; lemmas thin, with conspicuous nerves.....................69 
68b. Spikelets broadly ovate, $2-5 \mathrm{~mm}$. wide, with firm lemmas, the nerves not conspicuous. Fig. 102.

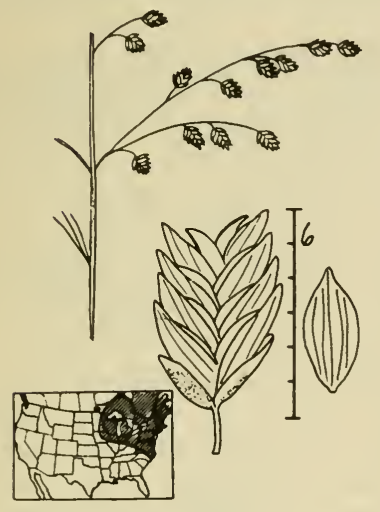

Figure 102

Glyceria canadensis (Michx.) Trin.

Perennial; tufted; plants $60-150 \mathrm{~cm}$. tall; panicles $12-20 \mathrm{~cm}$. long. Glyceria canadensis is one of the handsomest of grasses. The plump spikelets have a faint resemblance to snake rattles, hence the common name of "rattlesnake manna." Bogs, swamps, along streamlets. July-August.

$69 \alpha$. First glume $1 \mathrm{~mm}$. or less long...................

69b. First glume $1.4 \mathrm{~mm}$. or more long. Fig. 103.

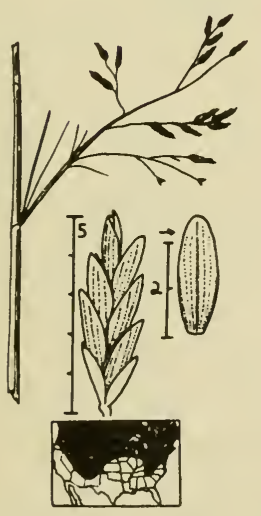

Glyceria grandis S. Wats.

Perennial; tufted; culms thick and tall, $1-1.5$ m. high; leaf blades $6-12 \mathrm{~mm}$. wide; spikelets 4-7 mm. long, with 4-7 florets; panicles 20$40 \mathrm{~cm}$. long. This is a tall species, with large, dense, panicles. It is one of the commonest species of the genus within its range. Marshes and stream banks. June-August.

Figure 103 
70a. Leaf blades $2-7 \mathrm{~mm}$. wide, firm; culms usually $1 \mathrm{~m}$. or less tall. Fig. 104.

Glyceria striata (Lam.) Hitch.

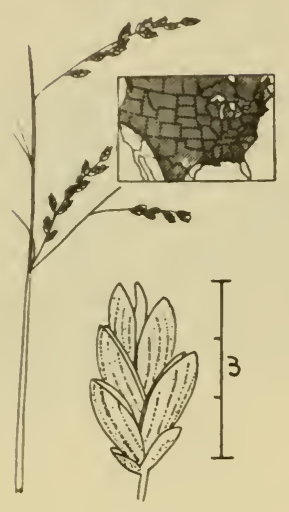

Figure 104

Perennial; forming large clumps; plants 30 $-100 \mathrm{~cm}$. tall; foliage glabrous; leaf blades flat or folded; panicles drooping, pyramidal, 10-20 cm. long; spikelets $3-4 \mathrm{~mm}$. long, usually with $3-7$ florets, often purplish. The spikelets shatter very readily when ripe. This is the most common and widespread of the American species of Glyceria. Usually one will find a colony of it around every pond, runnel, or ditch, and it may also grow in moist woods. The plants provide good forage for domestic livestock and elk, especially in later summer when the growth sites are drier. Sea level to $3300 \mathrm{~m}$. elevation. May-August.

(10)

70b. Leaf blades $6-12 \mathrm{~mm}$. wide, soft; culms usually $1-3 \mathrm{~m}$. tall. Fig. 105.

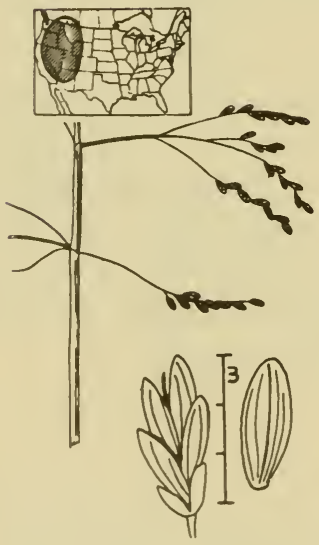

Figure 105
Glyceria elata (Nash) Hitch.

Perennial; tufted; dark green; tall and stout, with spongy culms; panicles oblong, $15-30 \mathrm{~cm}$. long, with spreading or drooping branches; foliage glabrous; leaf blades soft and thin; spikelets $4-6 \mathrm{~mm}$. long, with $6-8$ florets. This species looks like a larger version of the previous one, but it is restricted to the western states, where it is the most common and valuable forage species of the genus. Wet meadows, ponds, and moist woodlands. Eaten by all domestic livestock and elk; grazed primarily in late season when the herbage is less succulent and the habitats where it grows are less boggy. June-July. 
7la. Nerves of lemmas conspicuous; plants of wet, non-salty soils. 72

7lb. Nerves of lemmas inconspicuous; plants of salty or alkali soils. . 73

72a. Lemmas 5-nerved; plants found west of the 100th meridian. Fig. 106.

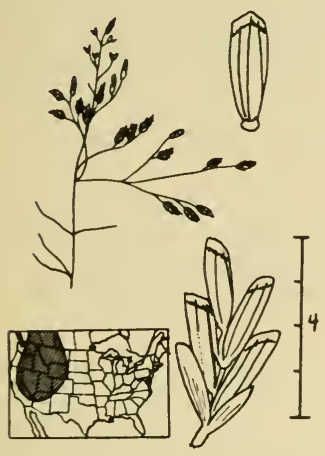

Glyceria pauciflora Presl

Perennial; tufted; leaf blades usually 10-15 cm. long; 5-15 mm. wide; plants $50-120 \mathrm{~cm}$. tall; panicles drooping, $10-$ $20 \mathrm{~cm}$. long; spikelets $4-5 \mathrm{~mm}$. long, usually with 5-6 florets. This and the next species depart from the usual in Glyceria by having split sheaths. The broad lemmas have a purple line near their translucent apex. Marshes, wet meadows, and shallow water, up to timber line. June -September.

Figure 106

72b. Lemmas 7-nerved; plants found east of the Mississippi. Fig. 107. Glyceria pallida (Torr.) Trin.

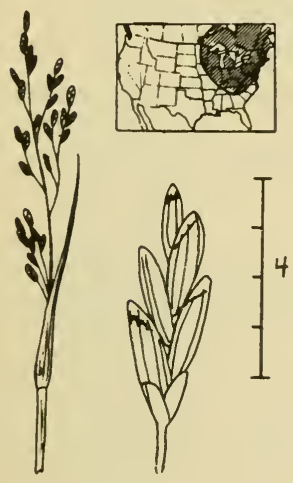

Figure 107
Perennial; plants weak and sprawling; culms $30-100 \mathrm{~cm}$. long; foliage glabrous; leaf sheaths split; blades usually $4-8 \mathrm{~mm}$. wide; panicles open, 5-15 cm. long; spikelets usually $6-7 \mathrm{~mm}$. long, with $4-7$ florets; tips of lemmas thin, membranous, irregular; lemmas $2.5-3 \mathrm{~mm}$. long. This species is found in cold, wet places, often in shallow water. May-June.

Var. fernaldii Hitch. is a late-blooming form with very narrow leaf blades, $1-3 \mathrm{~mm}$. wide. Wet places and shallow water; Newfoundland to Pennsylvania, westward to Minnesota and Wisconsin.

73a. Panicle pyramidal, open, the lower branches naked near their bases; plants widespread in the U. S.................74 
73b. Panicle dense, short, the branches bearing spikelets to their bases: plants of the Atlantic Coast. Fig. 108.

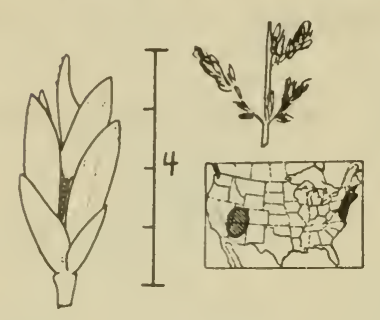

Figure 108

Puccinellia fasciculata (Torr.) Bickn.

Perennial; tufted; plants $20-50 \mathrm{~cm}$. tall; panicles 5-15 cm. long, stiff. Leaf blades flat, folded, or rolled, $2-4 \mathrm{~mm}$. wide. The species of Puccinellia grow on salty or alkaline wet soil. The lemmas frequently have handsome purplish, bronzy, or golden bands below the apex. This species occurs in salt marshes along the Atlantic Coast. June-?

74a. Lower panicle branches bent downward; lemmas blunt, broadest near the apex. Fig. 109.

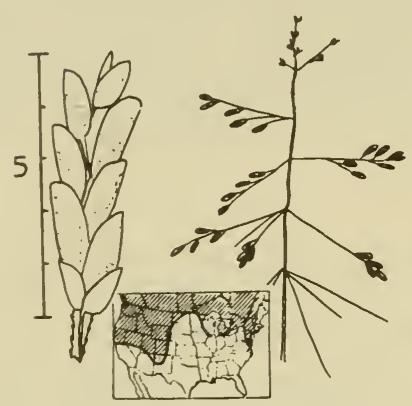

Puccinellia distans (L.) Parl.

Figure 109

74b. Lower panicle branches not bent down; lemmas acute, broadest near the middle. Fig. 110.

ALKALI GRASS Puccinellia airoides (Nutt.) Wats. and Coult.

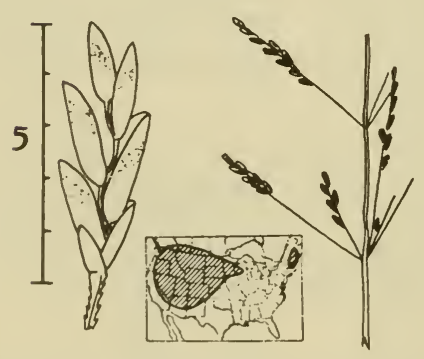

Figure 110
Perennial; tufted; plants $30-60$ $\mathrm{cm}$. tall; panicles $10-20 \mathrm{~cm}$. long. Leaf blades flat or rolled, $1-3$ $\mathrm{mm}$. wide. Similar to the preceding species, but with narrower lemmas. Native and widely distributed in the West. Sometimes cultivated under the name of Zawadke Alkali Grass. JuneAugust. Also called P. nuttalliana. 
75a. Lenma bearing an awn between two teeth, or from a point below the tip, or awnless but with a split tip. Fig. 111..76

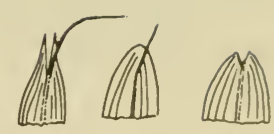

Figure 111

75b. Lemma awnless or bearing an awn at the very tip; tip of lemma

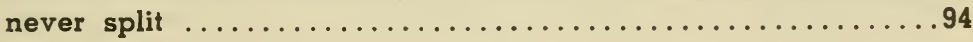

76a. Spikelets strongly laterally flattened, $2-4 \mathrm{~cm}$. long; lemmas V. shaped in cross section....................... 77

76b. Spikelets not strongly flattened, round in cross section before flowering: lemmas rounded on the back...............78

77a. Lemmas awnless or with a short awn less than $2 \mathrm{~mm}$. long. Fig. 112.

\section{RESCUE GRASS}

Bromus catharticus Vahl

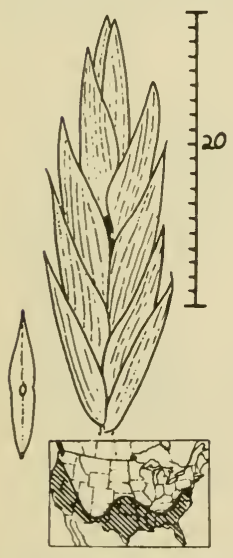

Figure 112

Annual; tufted; culms up to $100 \mathrm{~cm}$. long, erect or spreading; leaf sheaths and blades glabrous or hairy, dark green; panicles open, up to $20 \mathrm{~cm}$. long; spikelets $2-3 \mathrm{~cm}$. long, with $6-12$ florets; lemmas glabrous or rarely hairy, about $1.5 \mathrm{~cm}$. long, much flattened and closely overlapping. Rescue grass got its name from its winter annual habit, which makes it one of the earliest forage grasses in the South. It is planted in the fall for winter and spring pasture, but in many areas it has escaped from cultivation and is regarded as a wild plant. With good moisture, it makes lush, highly palatable forage. Heavy, rich soil, bottomlands. Native to South America. March-June. 
77b. Lemmas bearing awns 5-15 mm. long. Fig. 113.

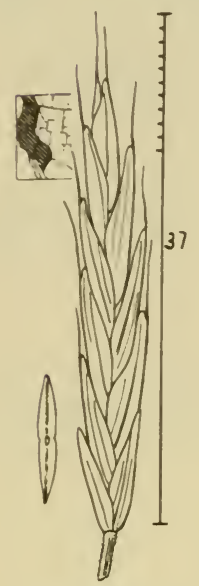

Figure 113

Annual or biennial; tufted; plants $50-100 \mathrm{~cm}$. tall or taller, vigorous and leafy; panicles 15-30 $\mathrm{cm}$. lony, with spreading or drooping branches; sheaths and leaf blades smooth or hairy; blades ranging from narrow and involute to broad and flat. $\AA$ number of closely related and intergrading plants, sometimes recognized as separate species, are included here. These plants are common on open ground and in thin woods in the western states and furnish a good deal of range forage. The foliage and the seed heads are eaten, the latter furnishing a good fattening ration for lambs. The seed of these plants is now available in commerce and the plants are used for range revegetation in the West. March-June.

78a. Lemmas broad, rounded or tapered to the apex, the lateral teeth at the base of the awn not long and sharp..............79

78b. Lemmas narrow, with a hard, sharp callus and long, sharp lateral teeth at the base of the awn.......................

79a. First glume l-nerved, narrowly lanceolate.............80

79b. First glume $3-5$-nerved, ovate or elliptical............

$80 a$. Plants tufted, without rhizomes: panicles mostly drooping: lemmas bearing well developed awns...................... 81 
$80 \mathrm{~b}$. Plants bearing rhizomes; panicles erect, with ascending branches: lemmas awnless or with very short awns, $1-2 \mathrm{~mm}$. long. Fig. 114. SMOOTH BROME

Bromus inermis Leyss.

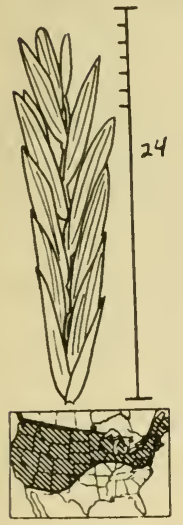

Perennial; $50-100 \mathrm{~cm}$. tall; panicles $10-20 \mathrm{~cm}$. long. Smooth brome, introduced from Eurasia, is one of our most successful forage grasses, and has been very widely planted in the U. S. for pasture and hay production. It frequently escapes to roadsides, ditches, and moist wooded areas. June-August.

Bromus pumpellianus Scribn. is a closely related species, native to the western states from the Black Hills to Colorado and Alaska. It has rhizomes but the lemmas are hairy. It hybridizes with $B$. inermis.

Figure 114

81a. Lemmas pubescent along the margins and lower part of the back, the central portion glabrous. Fig. 115 ..82

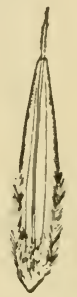

81 b. Lemmas pubescent across the back........... 83

Figure 115

82a. Ligule 3-5 mm. long; awns $5 \mathrm{~mm}$. or more long: plants of the western states. Fig. 116.

Bromus vulgaris (Hook.) Shear

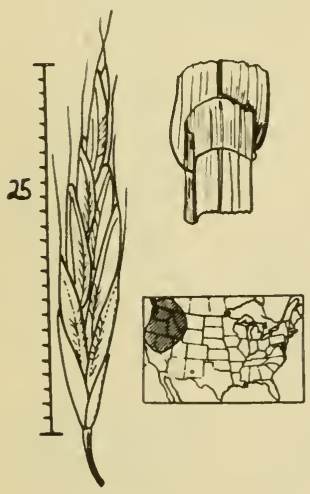

Perennial; tufted; plants slender; culms $80-120 \mathrm{~cm}$. tall; ligules prominent; leaf blades up to $12 \mathrm{~mm}$. wide; panicles drooping, $10-15 \mathrm{~cm}$. long; spikelets about 2.5 $\mathrm{cm}$. long; lemmas usually $8-10 \mathrm{~mm}$. long, hairy on the margins, glabrous or nearly so on the back; awns 5-8 $\mathrm{mm}$. long. Moist rocky woods and canyons. JulyAugust. Forms with nearly glabrous foliage and lemmas are known.

Figure 116 
82b. Ligule about $1 \mathrm{~mm}$. long: awn $3-5 \mathrm{~mm}$. long: plants widespread. Fig. 117.

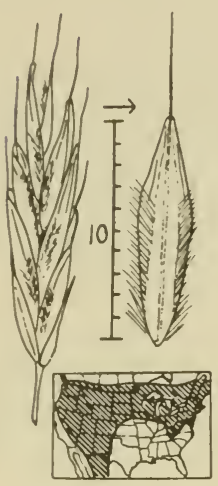

Bromus ciliatus L.

Figure 117

Perennial; tufted; plants $70-120 \mathrm{~cm}$. tall; panicles $15-25 \mathrm{~cm}$. long, drooping. Leaf sheaths glabrous or somewhat hairy; blades smooth or hairy, up to $1 \mathrm{~cm}$. wide. This species has handsome fringed spikelets. It is one of the most widespread of the native woodland bromes in moist rocky or alluvial woods. It provides excellent forage in the western states. July-August.

83a. Culms with $3-7$ nodes; sheaths without auricles. Fig. 118.

Bromus purgans L.

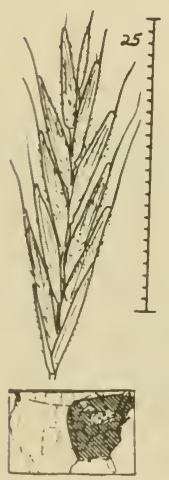

Figure 118

Perennial; tufted, in small clumps; culms erect or leaning; plants usually $60-150 \mathrm{~cm}$. tall; panicles open, drooping, usually $15-20 \mathrm{~cm}$. long; leaf sheaths shorter than the internodes, hairy or rarely glabrous; leaf blades 5-17 mm. wide; lemmas rather uniformly hairy across the back. This is the commonest woodland brome in the eastern United States. It is to be found in nearly every moist woods. June-July.

Forma glabriflorus Wiegand is a form of this species which has glabrous lemmas. It may be distinguished from other similar woodland bromes by the anthers, which are $3-4.5 \mathrm{~mm}$. long. 
83b. Culms with $10-20$ nodes, the sheaths longer than the internodes, bearing pointed appendages (auricles) at the throat. Fig. 119.

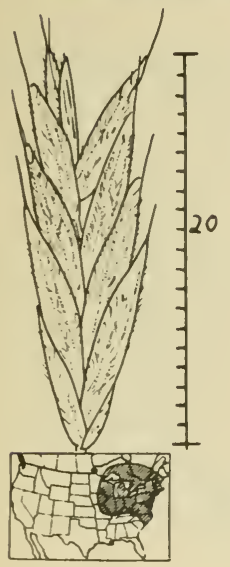

Brom:us latiglumis (Shear) Hitch.

Figure 119

Perennial; tufted; culms up to $2 \mathrm{~m}$. tall; panicles usually $15-25 \mathrm{~cm}$. long, rather dense. Leaf sheaths longer than the internodes, hence overlapping. This species blooms several weeks later than B. purgans. These two species frequently grow together. The sheaths are often covered with dense grayish wool. Alluvial bottomlands; prairies. July-September.

84a. Panicle open, pyramid-shaped, erect or drooping. .........85

84b. Panicle dense, ovoid, erect, with short branches and overlapping

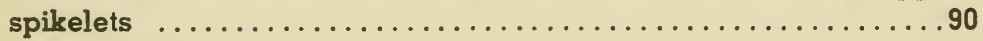

$85 a$. Lemmas glabrous or scabrous.................. 86

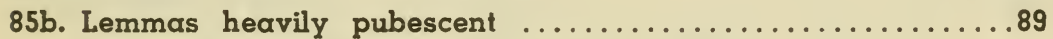

$86 a$. Lemmas bearing awns, not broad or inflated........... 87

$86 \mathrm{~b}$. Lemmas awnless or with minute awn tips, very broad and inflated. Fig. 120.

RATTLESNARE CHESS

Bromus brizaeformis F. \& M.

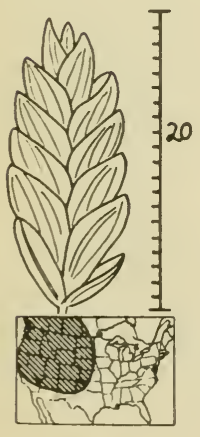

Annual; tufted; plants $30-60 \mathrm{~cm}$. tall; panicles drooping, 5-15 cm. long. The odd, inflated spikelets of this species look much like the rattlers of $a$ rattlesnake. It is sometimes planted for ornament and is occasionally found naturalized in fields and waste ground in the western states and elsewhere. Introduced from Europe. June-August.

Figure 120 
87a. Lemmas overlapping; rachilla not exposed; awns well developed; upper sheaths pubescent $\ldots \ldots \ldots \ldots \ldots \ldots \ldots \ldots \ldots \ldots . \ldots \ldots$

87b. Margins of lemmas rolling inward at maturity, exposing the rachilla; awns short, kinked; upper sheaths glabrous. Fig. 121.

CHESS, CHEAT

Bromus secalinus L.

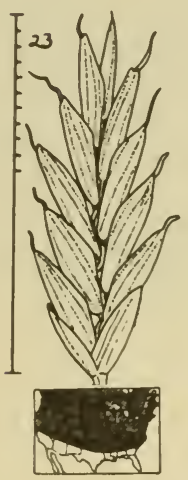

Annual; tufted; plants $30-60 \mathrm{~cm}$. tall; panicles $7-12 \mathrm{~cm}$. long. Chess is a common weed of roadsides and grainfields. Maturing quickly, the seeds may be harvested with wheat or other small grains and replanted elsewhere. Introduced from Europe. May-July. Old superstition claimed that cheat came from degenerate small grains, hence the name.

Figure 121

88a. Mature spikelets $3-5 \mathrm{~mm}$. wide; lower sheaths densely woolly with tangled or matted soft hairs. Fig. 122.

JAPANESE BROME

Bromus japonicus Thunb.

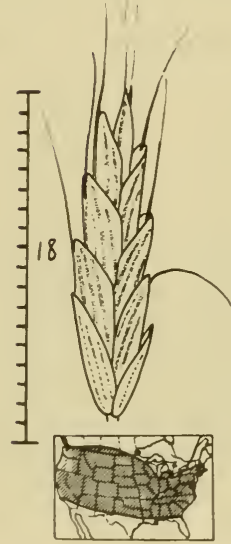

Figure 122

Annual; tufted; plants $40-70 \mathrm{~cm}$. tall; panicles drooping, with delicate flexuous branches. The awns may be straight or bent, depending upon their moisture content. Japanese brome was introduced from the Old World, and is now a very widespread weed of roadsides, fields, and waste ground. May-August.

Bromus arvensis L., similar to this species, is very rare in this country, but is often confused with Japanese brome. $B$. arvensis has anthers 3-4 $\mathrm{mm}$. long, those of $B$. japonicus being under $2 \mathrm{~mm}$. long. 
88b. Mature spikelets $5-8 \mathrm{~mm}$. wide: lower sheaths covered with straight spreading stiff hairs. Fig. 123.

Bromus commutatus Schrad.

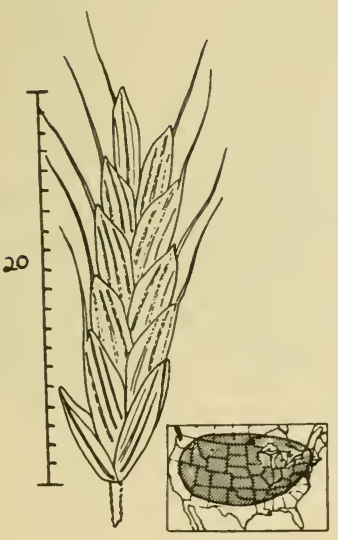

Figure 123

Annual; tufted; plants usually 30-100 $\mathrm{cm}$. tall, freely branching from the base; foliage hairy; panicles open, pyramidal, usually 5-15 cm. long. In plants growing on sterile dry soil, the inflorescence may be reduced to a raceme of a few spikelets. Such plants closely resemble $B$. racemosus (Fig. 127). This species is closely related to $B$. secalinus, from which it differs in the greater hairiness of the foliage and more overlapping florets. Along with $B$. japonicus and $B$. secalinus, this species is a widespread weed of fields and waste places. It is particularly common in the eastern and far western states, but apparently somewhat rare in the Middle West. Introduced from Europe. June-July.

89a. Leaf blades 2-4 mm. wide, sparsely hairy; from North Dakota to western Texas and westward. Fig. 124.

Bromus anomalus Rupr.

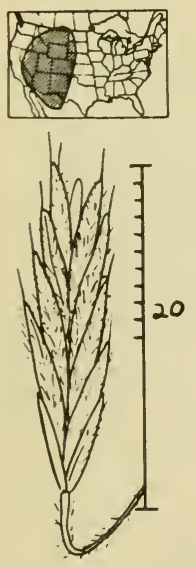

Perennial; tufted; culms slender, $30-60 \mathrm{~cm}$. tall; nodes hairy; sheaths somewhat hairy or glabrous; panicles small, drooping, usually $10 \mathrm{~cm}$. long or shorter; spikelets few, drooping, densely hairy; first glume with 3 nerves, the second with 5 ; lemmas about $12 \mathrm{~mm}$. long, the awns 2-4 $\mathrm{mm}$. long. Bromus anomalus is widespread and common in the Rocky Mountain region, where it is regarded as a very valuable forage grass for all kinds of domestic livestock and for wild grazing animals. It grows in aspen, spruce, and pine forests and on open ground in meadows and parks, at elevations up to $3000 \mathrm{~m}$. July-September.

Var. lanitipes (Shear) Hitch. has woolly sheaths. 
89b. Leat blades 5-10 mm. wide, densely hairy: Minnesota and lowa eastward. Fig. 125.

WILD CHESS

Bromus kalmii A. Gray
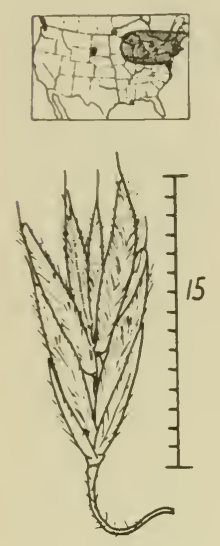

Perennial; tufted; plants $50-100 \mathrm{~cm}$. tall; panicles small, 5-10 cm. long, drooping. The lemmas are very conspicuously hairy. This and the preceding species are the only native perennial woodland species with 3-nerved first glumes. Roadsides and open woods. July-Āugust.

Figure 125

90a. Lemmas hairy. Fig. 126.

Bromus mollis L.

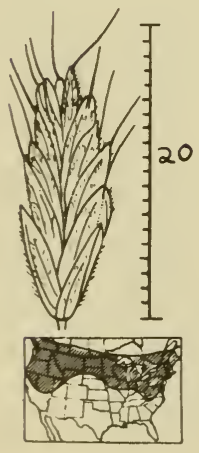

Figure 126

Annual; tufted; plants $20-80 \mathrm{~cm}$. tall; leaf sheaths and blades softly hairy; panicles stiff, dense, and erect, 5-10 cm. long; glumes and lemmas hairy; first glume with 3 or 5 nerves, the second with 5 or 7; lemmas soft, with 7 nerves, usually 7-9 $\mathrm{mm}$. long. This weedy species was introduced from Europe. It is found occasionally in the eastern and middlewestern states, but has become very abundant in the Pacific Coast states. It provides short-season spring forage, but because of its shallow roots and annual habit, does not effectively protect the soil from erosion and is regarded as much inferior to the perennial grasses which it replaces in overgrazed areas. April-June. Bromus mollis hybridizes with the next species. 
90b. Lemmas glabrous. Fig. 127.

Bromus racemosus L.

Annual; tufted; $20-80 \mathrm{~cm}$. tall; panicle stiff, dense, erect. Bromus racemosus closely resembles the preceding species and hybridizes with it. It is much less common in the eastern states, however. Starved plants of $B$. commutatus resemble $B$. racemosus but have more open panicles. This is a weedy annual of open ground, introduced from Europe. Low value, shortseason spring forage. Spring.

Figure 127

91a. Panicle open, the branches spreading or drooping

9lb. Panicle dense, erect. Fig. 128.

Bromus rubens L.

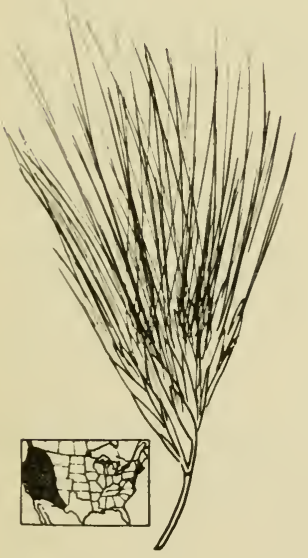

Annual; tufted; plants $15-40 \mathrm{~cm}$. tall; panicles $4-8 \mathrm{~cm}$. long. The little reddish bushy panicles look like ragged bristle brushes. Common in the Intermountain Region and Pacific Coast States, on open dry ground. The awns may injure livestock by piercing the facial tissues. Poor, scanty feed. March-June. Introduced from the Mediterranean area.

Figure 128

92a. Second glume at least $12 \mathrm{~mm}$. long; lemmas glabrous or sparsely stiff-hairy; awns $2-5 \mathrm{~cm}$. long...................93 
92b. Second glume $10 \mathrm{~mm}$. long or shorter; lemmas usually softly pubescent; awns $1-2 \mathrm{~cm}$. long. Fig. 129.

DOWNY BROME

Bromus tectorum L.

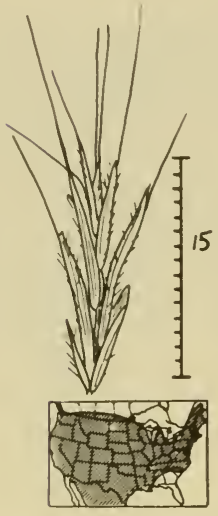

Figure 129

Annual; tufted; plants $30-60 \mathrm{~cm}$. tall; panicles drooping, 5-15 cm. long. The drooping, reddish panicles are rather ornamental, but the plants make poor, sparse feed and the sharppointed callus of the lemmas or the awns may penetrate the facial tissues of grazing animals. Of all the weedy European bromes, this is the commonest and most widespread. May-June. Melica smithii (see 56b) might be keyed here by the unwary. The plants are not hairy and it is a woodland perennial.

93a. Awns $2-3 \mathrm{~cm}$. long; first glume about $8 \mathrm{~mm}$. long. Fig. 130 .

Bromus sterilis L.

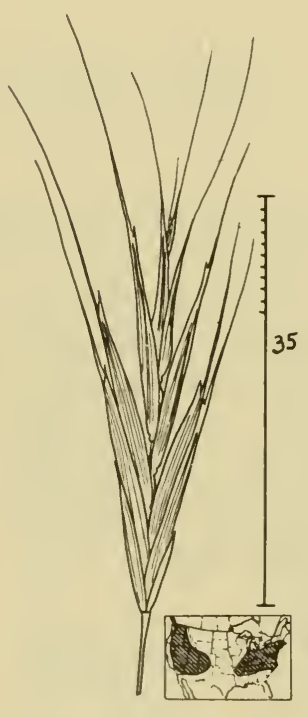

Figure 130

Annual; tufted; culms erect; plants 50$100 \mathrm{~cm}$. tall; leaf sheaths softly hairy or nearly smooth; ligules prominent, membranous, with a lacerated edge; leaf blades soft, sparsely hairy or nearly glabrous; panicles $10-20 \mathrm{~cm}$. long, open, with rather stiffly spreading or drooping branches; spikelets $2.5-3.5 \mathrm{~cm}$. long, with $6-10$ florets; lemmas $17-20 \mathrm{~mm}$. long, scabrous or stiff-pubescent; lateral teeth of the lemma about $2 \mathrm{~mm}$. long. The stiff florets, provided with sharp calluses and stiff barbed awns, penetrate the facial tissues of grazing animals. Since the plants are shallow-rooted annuals, they soon dry up and their forage value becomes very low. While very widespread in the United States, B. sterilis is nowhere particularly common. Introduced from Europe. April -July. 
93b. Awns 3-5 cm. long: first glume $1.5-2 \mathrm{~cm}$. long. Fig. 131 . RIP.GUT GRASS

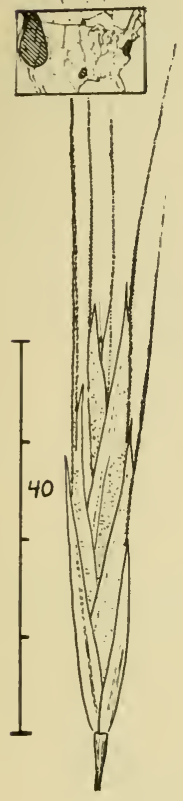

Figure 131

Annual; tufted; plant $40-70 \mathrm{~cm}$. tall; leaf sheaths and blades coarsely and sparsely hairy; ligules 3-7 $\mathrm{mm}$. long, membranous, with a lacerated margin; panicles dense, with few spikelets, drooping, $7-15 \mathrm{~cm}$. long, the lower branches only $1-2 \mathrm{~cm}$. long. Some variants have longer lower panicle branches, hence a more open panicle. Spikelets usually with 5-7 florets; glumes glabrous; lemmas scabrous or hairy; lateral teeth $3-5 \mathrm{~mm}$. long; awns strong, barbed. Because of the sharp calluses and strong, stiff awns of the lemmas, the florets readily penetrate the soft facial tissues of grazing animals, inflicting bad puncture wounds around the nose, mouth, and eyes, especially on sheep. Frequently these become infected, resulting in pink eye, cancer eye, or other disease conditions. The common name, rip-gut grass, arises from these dangerous properties of the florets. Poor, short-season feed. Introduced from Europe; especially common in California; rare in the eastern states. AprilÂugust.

94a. Lemmas awned or rarely awnless, tapering to sharp points: callus never bearing cottony hairs (see also Figs. 153 and 156).....95

94b. Lemmas awnless, not very sharp-pointed; callus frequently covered with crimped, cottony hairs

95a. Plants perennial, with hard bases; leaves flat or rolled or folded: culms mostly $30 \mathrm{~cm}$. tall or taller; stamens 3; florets opening at time of pollination. 
95b. Plants slender, annual, with shallow roots and hair-like leaves; culms usually less than $20 \mathrm{~cm}$. tall; stamens usually l; florets cleistogamous. Fig. 132.

SIX WEERS FESCUE

Festuca octoflora Walt.

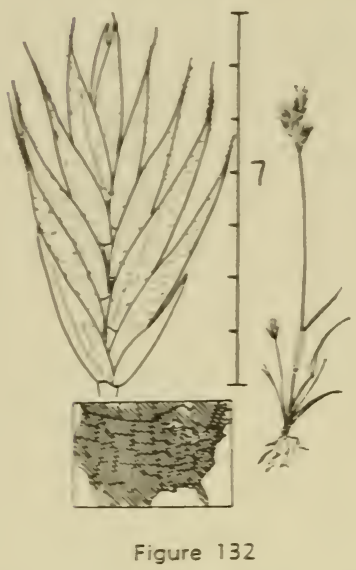

Annual; tufted, seldom over $20 \mathrm{~cm}$. tall. The leaves are borne mostly in a short basal tuft. The plants may be found on poor, usually sondy ground, throughout the United States. Forage value very low. The common name refers to the very short life span. This and a num. ber of small species of other genera, with similar growth habits, go by the name of "six weeks grasses." All may provide short-term emergency feed for range livestock after rains. April-July.

Twelve other similar species of Festuca occur in parts of the U. S., but are much less common. They are sometimes put in the genus Vulpia.

96a. Leaf blades flat, soft, the larger ones more than $3 \mathrm{~mm}$. wide; lemmas awnless or nearly so................... 97

96b. Leaf blades rolled or folded, firm, less than $3 \mathrm{~mm}$. wide; lemmas awned or awnless.............................99

97a. Spikelets usually less than $10 \mathrm{~mm}$. long, with 5 or fewer florets. .98 97b. Spikelets $8-18 \mathrm{~mm}$. long, with $8-10$ florets. Fig. 133. MEADOW FESCUE

Festuca elatior L.

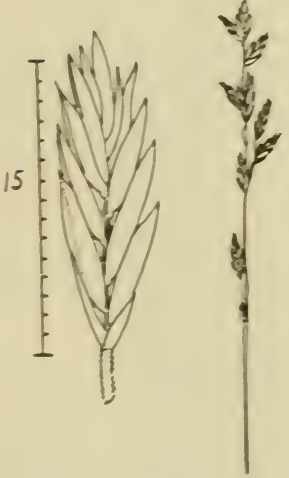

Perennial; tufted; plants $50-120 \mathrm{~cm}$. tall; leaf blades $4-8 \mathrm{~mm}$. wide; panicle $10-20$ $\mathrm{cm}$. long, narrow cylindrical while flowering, but contracted and spikelike afterward. This species was introduced from Europe as a forage plant and has now become widely dispersed in meadows, pastures, roadsides and waste places in the northern states. Forage value good. June-July. 
98a. Panicle branches short, erect, bearing spikelets nearly to their bases: plants of the Rocky Mts. Fig. 134.

SPIRE FESCUE

Hesperochloa kingii (S. Wats.) Rydb.

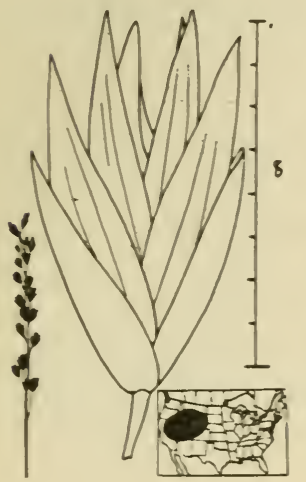

Figure 134

Perennial; tufted or sometimes bearing rhizomes; plants $40-100 \mathrm{~cm}$. tall; panicles $7-20 \mathrm{~cm}$. long. Spike fescue has the staminate and pistillate spikelets on separate plants (dioecious). While the spikelets are similar, the pistillate ones have well developed ovaries and abortive anthers, less than a millimeter long, while the staminate ones have large anthers, about $4 \mathrm{~mm}$. long, and no ovaries. Grazed by cattle and sheep. Dry mountains, at medium altitudes. May-August. Also called Festuca kingii.

98b. Panicle branches slender, drooping; bearing spikelets only near the outer ends; Dakotas to Texas and eastward. Fig. 135. NODDING FESCUE

Festuca obtusa Biehler

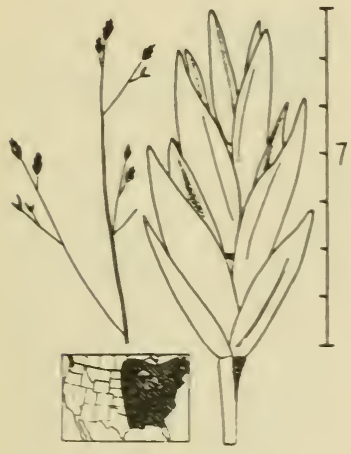

Figure 135

Perennial; tufted; plants $50-100 \mathrm{~cm}$. tall; panicles usually $15-20 \mathrm{~cm}$. long. Nodding fescue is a species found in forests of the eastern half of the United States. The plants grow in small clumps, with somewhat spreading culms and drooping panicles. The spikelets shatter almost before reaching full size, making it difficult to find complete ones. May-September.

A similar but rarer species is $F$. paradoxa Desv., which bears 8-20 spikelets, 4-6 mm. wide, on each lower panicle branch.

99a. Lemmas awnless 100

99b. Lemmas bearing awns $2 \mathrm{~mm}$. or more long............ 102 
100b. Ligules $2-4 \mathrm{~mm}$. long. Fig. 136.

Festuca thurberi Vasey

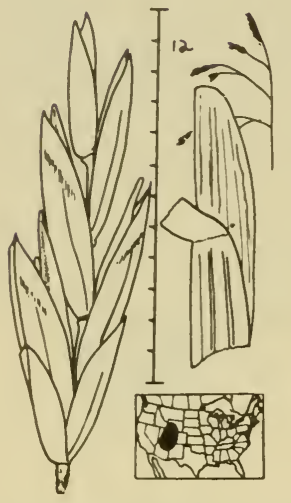

Figure 136

Perennial; densely tufted; culms rather stout, $60-100 \mathrm{~cm}$. tall. The involute leaves are scabrous. Panicles $10-15 \mathrm{~cm}$. long, the branches separate or paired, as much as 8 $\mathrm{cm}$. long, and bearing spikelets only near their ends. The long ligule is characteristic. Dry rocky slopes, 2500-3500 m.. elevation. Forage value good. July-August.

101a. Leaves soft, green. Fig. 137.

Festuca viridula Vasey

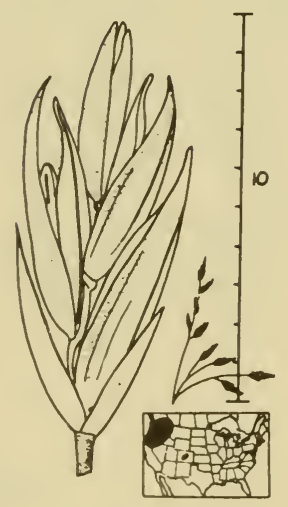

Figure 137

Perennial; in dense tufts; culms 50-100 $\mathrm{cm}$. tall; panicles open, $10-15 \mathrm{~cm}$. long; branches mostly paired, $2-4 \mathrm{~cm}$. long; leaf blades soft, folded or rolled; spikelets with 3-6 florets; lemmas 6-8 $\mathrm{mm}$. long. The lemmas are softer than those of other species of fescue, and frequently have some purplish coloration. Well drained soils in the spruce-fir forests near timberline; mountainsides, parks, and meadows. Green fescue is one of the best forage grasses of the Northwest. It is high in palatability and nutritive value, and is eaten throughout the grazing season by all classes of livestock. July-September. 
101b. Leaves stiff, bluish. Fig. 138.

ARIZONA FESCUE; PINEGRASS

Festuca arizonica Vasey

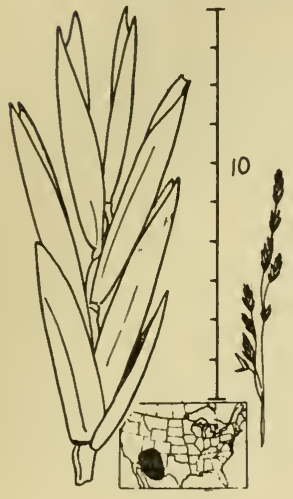

Figure 138

Perennial; densely tufted; culms about 50 $\mathrm{cm}$. tall; leaves stiff, pale, rather scabrous; panicles narrow, $8-20 \mathrm{~cm}$. long, with one or two spreading branches at the base. Open pine forests, mountains of the Southwest. An important grazing grass, closely related to the more northerly $F$. idahoensis (Fig. 141). July-August.

Festuca capillata Lam., commonly called HAIR FESCUE, is a much smaller plant, with spikelets under $5 \mathrm{~mm}$. long, and short, spikelike panicles less than $5 \mathrm{~cm}$. long. It occurs in lawns and waste places in the eastern states and westward to Illinois; Oregon. Introduced from Europe.

102a. New leafy shoots arising within the old sheaths; plants forming dense tufts; old sheaths not reddish nor fibrous......... 103

102b. New leaty shoots breaking through the bases of the sheaths and spreading at the base, the plants hence forming loose turfs; old basal sheaths reddish brown, finally shredding into brownish threads. Fig. 139.

RED FESCUE

Festuca rubra L.

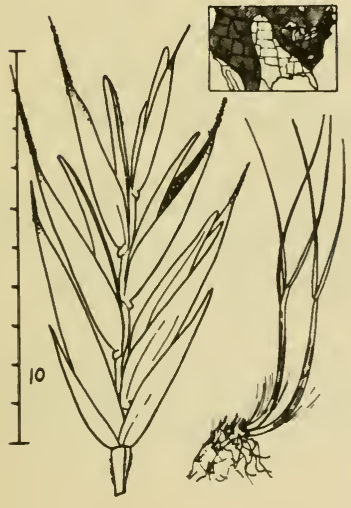

Figure 139

Perennial; tufted; culms $40-100 \mathrm{~cm}$. tall; panicle slenter, the short branches ascending. Wet or dry ground; widespread in the eastern United States and in the western mountains. $\AA$ number of forms of this species are used in lawn mixtures. Chewings fescue and creeping red fescue are among these. Red fescue is native in Europe, Asia, and North Africa as well as North America. Most of the occurrences in the eastern states seem to be introductions, probably in lawn seed mixtures. May-July.

Festuca occidentalis Hook. has somewhat similar culm bases but the awns are as long as the lemmas and the long, spreading panicle branches bear spikelets only near their tips. Northwestern states; northern Michigan and Ontario. 
103a. Leaf blades less than one half the culm length: panicles less than $10 \mathrm{~cm}$. long: plants usually less than $30 \mathrm{~cm}$. tall; widespread in the U. S. Fig. 140.

SHEEP FESCUE

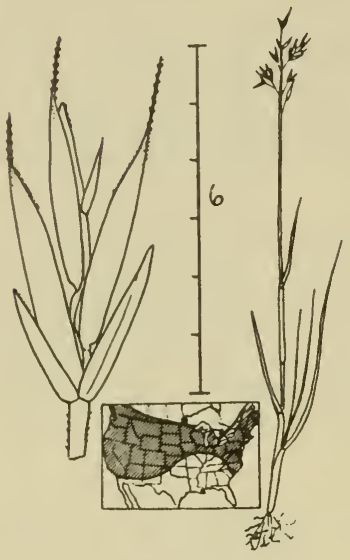

Figure 140

Festuca ovina L.

Perennial; tufted; $20-40 \mathrm{~cm}$. tall, with a small, narrow panicle. Since the sterile leafy shoots (innovations) arise within the old sheaths, the plants form dense, bumpy tufts, making this species undesirable as a lawn grass. It frequently appears in old neglected lawns. In mass, the plants have a grayish-green color, but they do not turn brown during dry splls, as bluegrass does. Regarded as good forage in the western mountains. Native also to Europe and Asia. May-June.

Var. brachyphylla (Schult.) Piper is a dwarf, high altitude form found above timber line in the western mountains, where it is important for grazing. Culms $5-20 \mathrm{~cm}$. tall.

103b. Leaf blades more than one half the culm length; plants $30-100$ $\mathrm{cm}$. tall; panicles 10-20 cm. long; in the western mts. Fig. 141 . BLUEBUNCH FESCUE

Festuca idahoensis Elmer

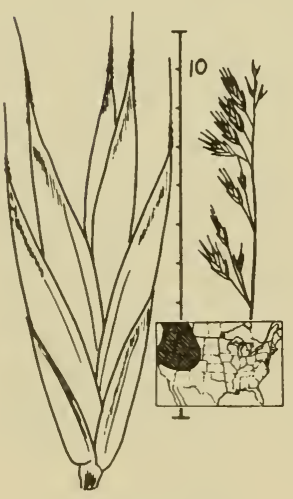

Perennial; forming large tufts, the densely crowded slender culms up to a meter in height. The panicles are slender, $10-20 \mathrm{~cm}$. long, usually with a single longer spreading lower branch. The leaves are rough and glaucous, but not as stiff as those of the closely related Arizona fescue (see 101b). Important as a range forage grass. JuneAugust.

Figure 141

104a. Plants producing rhizomes........................ 105

104b. Plants tufted, without rhizomes.................... 
105a. Culms round or nearly so in cross section (in pressed specimens,

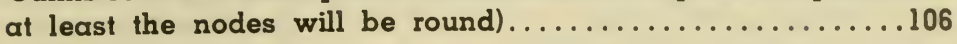

105b. Culms strongly, flattened, lens-shaped in cross section; spikelets never woolly. Fig. 142.

CANADA BLUEGRASS

Poa compressa L.

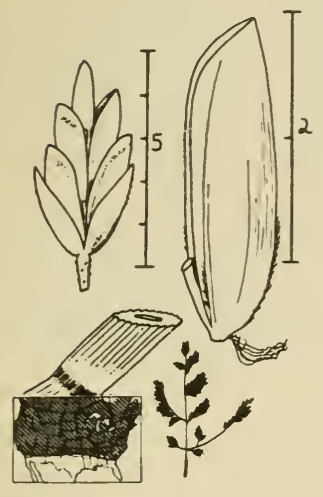

Figure 142

Perennial; rhizome-bearing; panicles narrow, $3-7 \mathrm{~cm}$. long. The plants are rather wiry and form looser turf than Kentucky bluegrass. It is somewhat more drought resistant than the former species, but yields less forage. The plants bloom several weeks later than Kentucky bluegrass in the same locality. Mid-May-September. Introduced from Europe.

106a. Lemmas completely glabrous or minutely scabrous, or with a small web of cottony hairs (Fig. 143) attached to the callus..................... 107

106b. Lemmas pubescent on the keel or nerves, sometimes with $a$ web at the base also..........108

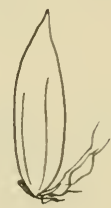

Figure 143

107a. Panicles dense, with short branches, the spikelets overlapping: southern plains states or Southeast................110b

107b. Panicles open, the slender spreading branches naked at the base: western mountains $.109 b$

108a. Lemmas pubescent only on the nerves; glabrous between them 109 
108b. Lemmas pubescent on the nerves and also between them near the base. Fig. 144.

PLAINS BLUEGRASS

Poa arida Vasey

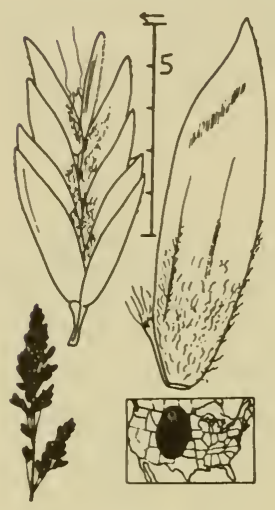

Figure 144

Perennial; producing rhizomes; culms 20 $60 \mathrm{~cm}$. tall; leaf blades borne mostly near the base of the plant, folded, $2-3 \mathrm{~mm}$. wide; panicle dense, cylindrical, $2-10 \mathrm{~cm}$. long, with short branches; spikelets $5-7 \mathrm{~mm}$. long, the first glume with one nerve; anthers about $1.5 \mathrm{~mm}$. long. Salty or alkaline meadows, up to $3000 \mathrm{~m}$. elevation; an important forage grass on the Great Plains. June-?

Poa glaucifolia Scribn. \& Will. is similar. The first glume has 3 nerves; anthers about $2.5 \mathrm{~mm}$. long; panicles more open; herbage glaucous. Moist ground and open woods; Minn. to B. C., to Nev. and N. M.

109a. Lemmas bearing a web of cottony hairs at the base; sheaths glabrous

109b. Lemmas without $a$ web of hairs; lower sheaths glabrous or pubescent. Fig. 145 .

Poa nervosa (Hook.) Vasey

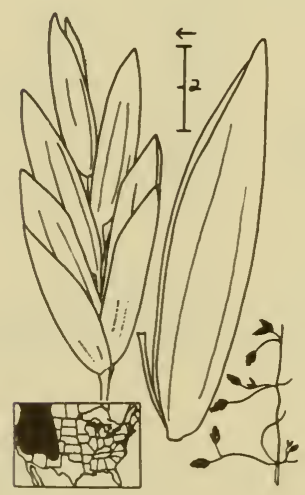

Figure 145

Perennial; producing rhizomes; culms 30 $-70 \mathrm{~cm}$. tall, in large, leafy tufts; leaf blades flat or folded; ligules $1-2 \mathrm{~mm}$. long; panicles open, usually 5-10 cm. long, with drooping branches which are naked at the base. The lemmas vary from entirely glabrous to hairy on the nerves or scaberulous. This species is highly variable in the hairiness of both sheaths and lemmas. In common with most of the native and introduced bluegrasses, it is a valuable forage plant for domestic grazing animals and wild herbivores. Dry soil in open woods, intermediate altitudes. May -August.

110a. Panicles open, the long branches naked at the bases.......111 
110b. Panicles dense and compact, cylindrical, with overlapping spikelets. Fig. 146.

TEXAS BLUEGRASS

Poa arachnifera Torr.

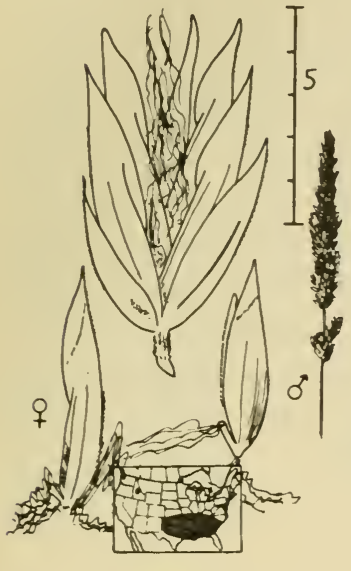

Figure 146

Perennial; rhizomes present; plants producing leafy tufts; culms $30-75 \mathrm{~cm}$. tall; leaf blades dark green, 2-4 mm. wide, scabrous on the upper surface; panicles lobed, 5-12 cm. long; spikelets usually with 5-10 florets. The staminate and pistillate spikelets are on different plants, and the two kinds are quite different in appearance. The pistillate panicles are wooly due to the presence of copious cottony webs on the lemmas. The staminate inflorescences are not woolly, their lemmas having only small webs or none at all. The plants are succulent and very leafy; they provide excellent forage in winter and spring. Sometimes cultivated for forage in the southeastern states. AprilMay.

Poa macrantha Vasey is also dioecious. It is a sand-binder on the coastal dunes from Washington to northern California. The plants have extensive rhizomes and stolons. Spikelets large, about $12 \mathrm{~mm}$. long; webs scanty.

11la. Lower panicle branches mostly in pairs; lemmas $3.5-5.4 \mathrm{~mm}$. long: anthers $2.0-3.5 \mathrm{~mm}$. long. Fig. $14 \%$.

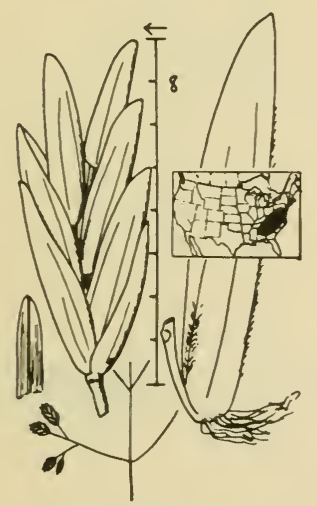

Figure 147

Poa cuspidata Nutt.

Perennial; rhizomes present; culms $30-$ $50 \mathrm{~cm}$. tall; plants growing in large tufts, with numerous long basal leaves nearly as long as the culms; leaf blades soft, $2-3$ $\mathrm{mm}$. wide; upper culm blades very short, rounded to an abrupt tip; panicles $7-12$ $\mathrm{cm}$. long, very open, pyramidal, the spikelets all borne at the outer tips of the branches. This is the earliest blooming of all the native eastern grasses, usually beginning to flower in early April in the North. It is a plant of the central and southern Appalachians, where it is commonly found on rocky banks and dry wooded hillsides. Unlike Kentucky bluegrass, which it resembles, it completely

lacks aggressive or weedy tendencies. 
111b. Lower panicle branches mostly in whorls of 5; lemmas $2.4-3.6$ $\mathrm{mm}$. long; anthers $1.0-1.8 \mathrm{~mm}$. long. Fig. 148.

RENTUCKY BLUEGRASS

Poa pratensis L.

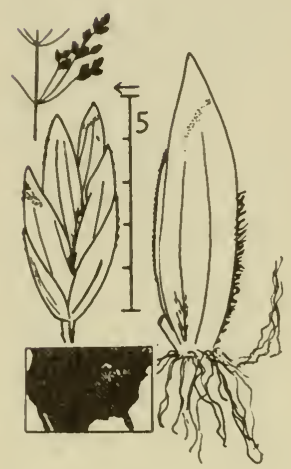

Figure 148

Perennial; rhizomes present; culms $30-100$ $\mathrm{cm}$. tall, in dense clumps with numerous sterile leafy shoots (innovations); panicles open, pyramidal, somewhat contracted after flowering. Kentucky bluegrass is one of our most widely distributed introduced grasses and is much used for lawns and pastures in the northern states. It is extensively naturalized in pastures, prairies, roadsides, open woods and waste ground. April-July. Introduced from Europe.

112a. Lemmas bearing $\alpha$ web

112b. Lemmas glabrous or pubescent, but without a web......118

113a. Marginal nerves of lemmas pubescent.............114

113b. Marginal nerves of lemmas glabrous..............117

114a. Lemmas glabrous between the nerves; ligules of upper culm

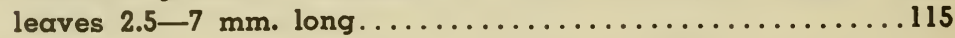

114b. Lemmas pubescent between the nerves; ligules almost always

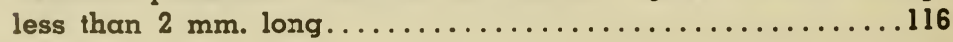


115a. Lemmas greenish-yellow, thin, with prominent intermediate nerves; sheaths usually scaberulous. Fig. 149.

ROUGH STALK BLUEGRASS; TRIVIALIS

Poa trivialis L.

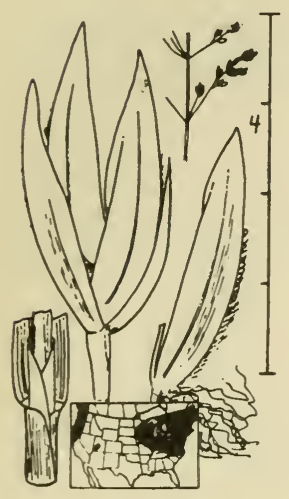

Perennial; tufted; culms $30-100 \mathrm{~cm}$. tall, often somewhat bent or reclining at the base; panicles open, ovoid or pyramidal, the spikelets clustered near the outer ends of the branches; lemmas glabrous or hairy on the lateral nerves. The plants are often found growing wild in wet places, and the seed is planted in lawn mixtures for shady places. May-June. Introduced from Europe.

Figure 149

$115 b$. Lemmas green, usually purple or bronzy at the tip, the intermediate nerves inconspicuous; sheaths smooth. Fig. 150.

Poa palustris L.

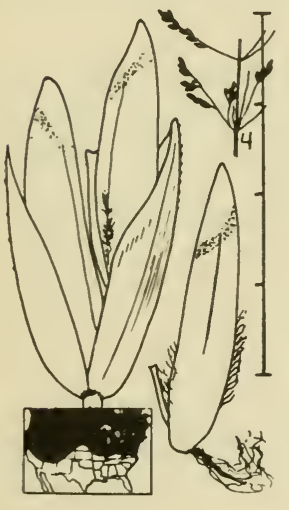

Figure 150

Perennial; plants slender, weak, with bent and reclining (decumbent) culm bases; panicles open, pyramidal, with slender, weak branches. The lemmas are usually purple and golden banded near the tip, making them very attractive under the lens. Wet meadows, stream banks, and moist woods; seldom numerous in one place. June-August. This species is native to both North America and Eurasia.

Poa interior Rydb. is very similar to the above, but has erect, tufted culms, small panicles less than $10 \mathrm{~cm}$. long, and short ligules usually $1 \mathrm{~mm}$. long or shorter. Across Canada and south to northern New England, Wisconsin, North Dakota and the high plains

and western mountain states. 
11.6a. Panicles cylindrical, 10-20 cm. long, the branches $3-6$ in a whorl: lower branches drooping........ See P. sylvestris under P. alsodes, $117 \mathrm{~b}$.

116b. Panicles pyramidal, 5-10 cm. long, the branches $1-2$ at a node, ascending....... See $P$. interior under $P$. palustris $115 \mathrm{~b}$.

117a. Upper ligules 3-7 mm. long; sheaths usually scaberulous; intermediate nerves of lemmas conspicuous..............115a

117b. Upper ligules $0.5-2 \mathrm{~mm}$. long; sheaths smooth; intermediate nerves of lemmas inconspicuous. Fig. 151.

Poa alsodes A. Gray

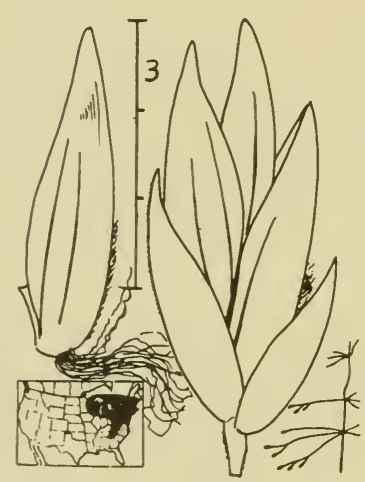

Figure 151

Perennial; tufted; plants slender, 30$60 \mathrm{~cm}$. tall, erect and graceful, with very open, delicate, cylindrical panicles, 10 $-25 \mathrm{~cm}$. long and half as wide. The slender branches bear a few spikelets near their tips. Cool rocky woods or wooded flood plains in the northeastern states and the Appalachians. MayJune.

Poa sylvestris A. Gray is found also in rich woods and resembles this species, but has lemmas which are hairy between the nerves. New York to Wisconsin, southward to Florida and Texas. May-July.

118a. Lemmas pubescent between the nerves, the hairs often very short 119

118b. Lemmas glabrous between the nerves................ 120 
119a. Panicles very open, the branches slender, spreading, usually in pairs, bearing spikelets only near their outer ends; lemmas with consp:cuous long hairs on their keels; eastern forested half of the U. S., to Michigan and Texas. Fig. 152.

Poa autumnalis Muhl.

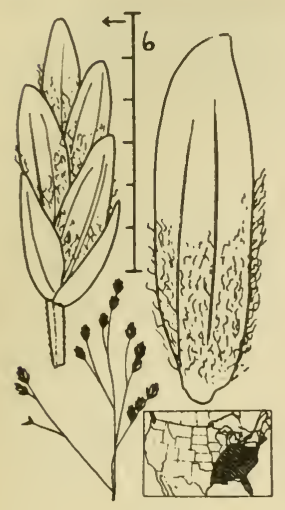

Perennial; tufted; plants delicate, 30-60 $\mathrm{cm}$. tall; panicles $10-20 \mathrm{~cm}$. long and nearly as wide, their branches very slender, bearing a few spikelets near the tips. Leaf blades 2 $-3 \mathrm{~mm}$. wide, many at the base of the plants. The plants are not, as the name would seem to indicate, autumn blooming. Moist woodlands. June.

Figure 152

119b. Panicles usually dense, the branches bearing spikelets nearly to their bases; nerves of lemmas not bearing long hairs; western states, eastward to Minnesota and to the Dakotas. Fig. 153.

Poa scabrella (Thurb.) Benth.

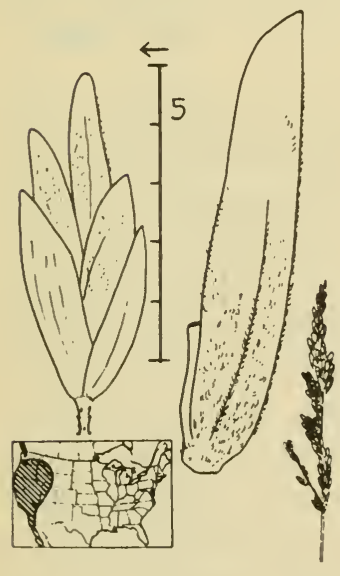

Perennial; tufted; culms $50-100 \mathrm{~cm}$. tall; pcrinicles slender, elongated, with ascending branches. This species and its relatives have lemmas covered, at least near their bases, with short crimped or appressed hairs. A number of very closely related species or forms exist in this group, differing mostly in the shape of the panicle. All are bunch grasses of the western states and are valuable forage grasses at lower and medium altitudes. March-August.

Figure 153 
120a. Midnerve and lateral nerves of lemmas pubescent.......121

$120 \mathrm{~b}$. Lemmas glabrous or minutely scaberulous, not pubescent. . 122

12la. Spikelets $6-8 \mathrm{~mm}$. long: keels and marginal nerves of lemmas pubescent; intermediate nerves inconspicuous, not pubescent. Fig. 154،

MUTTON GRASS

Poa fendleriana (Steud.) Vasey

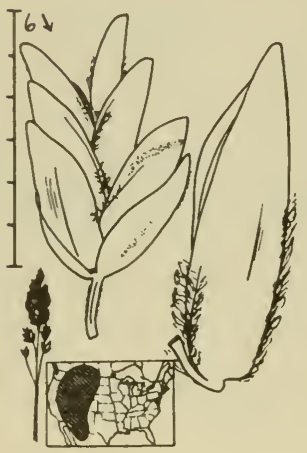

Figure 154

Perennial; erect, densely tufted bunch grass; leaves mostly basal, stiff and scabrous, folded or rolled, $1-2 \mathrm{~mm}$. wide; culms $30-50 \mathrm{~cm}$. tall, not much exceeding the basal leaves; panicles dense, oblong, 2-7 $\mathrm{cm}$. long, the pale spikelets overlapping. The plants are dioecious but the spikelets of both sexes are similar. Ligules short, less than $1 \mathrm{~mm}$. long. Medium altitude hills and dry forests in the western mountains, from $2300-4000 \mathrm{~m}$. It is regarded as one of the best of the western forage grasses, especially for sheep. April -July.

Poa longiligula Scribn. \& Will. is very similar, but has ligules up to 5-7 mm. long. Range about the same as the preceding species.

121b. Spikelets 4-6 $\mathrm{mm}$. long; keels, intermediate nerves, and marginal nerves of lemmas conspicuous, usually all pubescent. Fig. 155.

ANNUAL BLUEGRASS

Poa annua L.

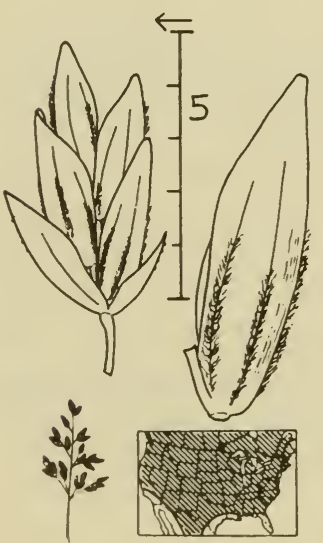

Figure 155

Annual; tufted. The diminutive light green plants, usually less than $20 \mathrm{~cm}$. tall, are soft, weak, and spreading. Panicles 3-7 cm. long, pyramidal, with short, spreading branches. The plants sometimes grow in shallow water, then becoming long, slender, and rooting at the nodes. This species begins growth in fall or early spring and blooms very early, and may die out when hot weather comes. Some blooming also occurs in fall. Lawns, paths, margins of water and open woods, roadsides. Introduced from Europe. 
122a. Panicles short, ovoid, $2-8 \mathrm{~cm}$. long; spikelets ovate in outline, about twice as long as wide; glumes and lemmas keeled; nerves

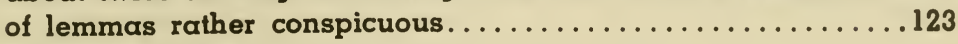

122b. Panicles elongated, cylindrical, 10-15 cm. long; spikelets little keeled, narrowly elliptical in outline, 3 or more times longer than wide, the glumes and lemmas rounded on the back; nerves of lemmas inconspicuous. Fig. 156.

Poa nevadensis Vasey

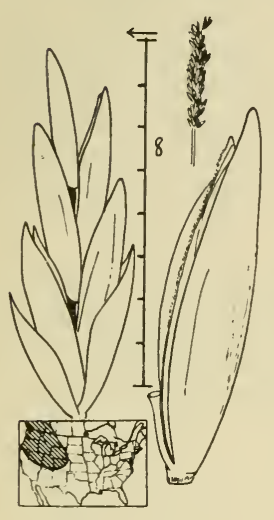

Figure 156

Perennial; tufted; culms erect, $50-100 \mathrm{~cm}$. tall; sheaths scabrous; panicle narrow, elongated, $10-15 \mathrm{~cm}$. long. This is one of a group of very similar bunchgrasses of the western mountain states. All have slender, elongated spikelets, whose lemmas are not keeled; lemmas glabrous and with inconspicuous nerves. They furnish excellent range forage for wild game animals and domestic livestock. Plains, dry meadows; open or partially wooded mountainsides, from near sea level up to $3700 \mathrm{~m}$. elevation. MaySeptember.

123a. Leaf blades scabrous; ligules of culm leaves less than $2 \mathrm{~mm}$. long. Fig. 157.

Poa cusickii Vasey

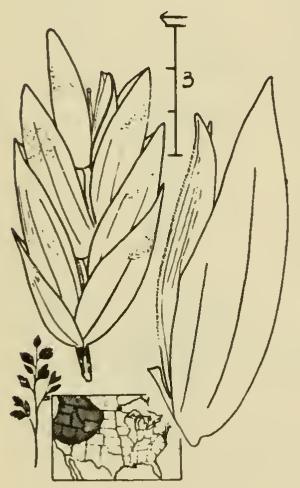

Perennial; culms in dense bunches, $20-60$ $\mathrm{cm}$. tall; basal leaf blades thread-like, very scabrous, about half the length of the culms; ligules usually under $1 \mathrm{~mm}$. long; panicles 3-8 cm. long, dense, oblong, pale or somewhat purplish. Rocky slopes and sagebrush plains, medium to high altitudes. May-July.

Figure 157 
123b. Leaf blades glabrous; ligules of culm leaves $2-4 \mathrm{~mm}$. long. Fig. 158.

Poa epilis Scribn.

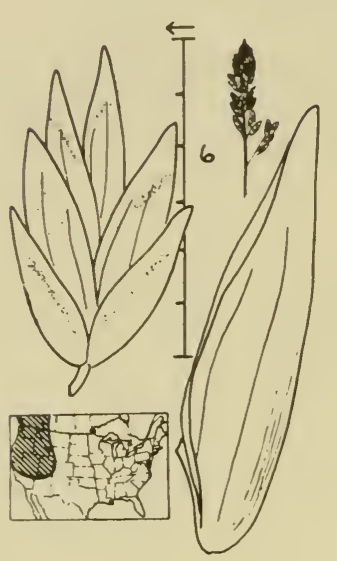

Figure 158

Perennial; culms in small tufts; plants $20-40 \mathrm{~cm}$. tall; leaf blades of the culms short, flat, 2-3 $\mathrm{mm}$. wide, their ligules 2-4 $\mathrm{mm}$. long; basal leaves long, folded or rolled; panicles on long, thin peduncles; panicles short, dense, oblong, 2-6 $\mathrm{cm}$. long; spikelets about $5 \mathrm{~mm}$. long, usually with 3 florets; lemmas $4-6 \mathrm{~mm}$. long, sometimes scaberulous. Poa epilis, sometimes called "skyline bluegrass," is an important high altitude forage grass, usually found above timberline on steep slopes and in mountain meadows. July-August.

About five similar species are to be found at high altitudes in the western mountains, mostly above timberline. They are all dwarf, rarely more than $20 \mathrm{~cm}$. tall.

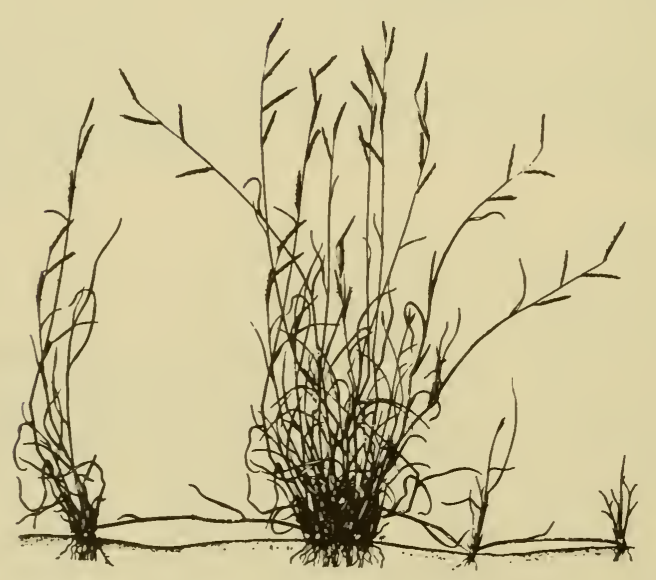




\section{TRIBE III. HORDEAE}

la. One spikelet borne at each node of the rachis...........

1b. Two or more spikelets borne at some or all of the nodes of the rachis (some spikelets may be reduced to awned rudiments)...10

2a. Rachis not breaking up at maturity, the joints thin and flat....3

2b. Rachis breaking into individual joints at maturity: joints much thickened at their upper ends; spikes cylindrical. Fig. 159.

GOATGRASS

Aegilops cylindrica Host

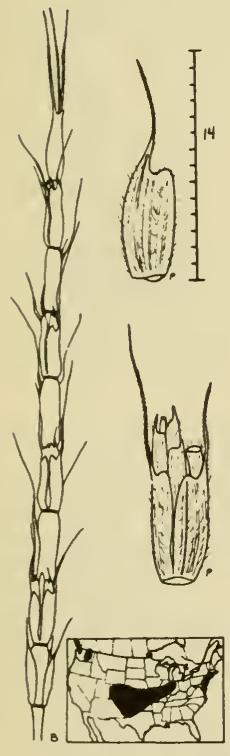

Figure 159

Annual; tufted; $40-60 \mathrm{~cm}$. tall; much branched from the base, one plant bearing as many as 60 spikes; spikes $5-10 \mathrm{~cm}$. long; joints of the rachis $6-8 \mathrm{~mm}$. long, the spikelets slightly longer and fitting closely into the contour of the joints; spikelets glabrous or hairy, with 2-5 florets; lower spikelets nearly awnless, the upper ones bearing awns up to $5 \mathrm{~cm}$. long; glumes thick and stiff, bearing a pronounced tooth at one side of the awn. Goatgrass was presumably introduced into the Middle West in Turkey wheat brought to the United States by Russian immigrants in the 1870's. The plants are winterannual, beginning growth in the fall and seeding out from May to July. They crowd out wheat when they are numerous. The seeds travel as contaminants in wheat seed.

Aegilops triuncialis L. is similar but has three awns on each glume. It is a bad weed on range land in California; introduced from Europe.

Sa. Spikelets placed flatwise against the rachis; both glumes present. . 4 
3b. Spikelets placed edgewise to the rachis; only the glume away from the rachis present. Fig. 160.

RYEGRASS

Lolium perenne L.

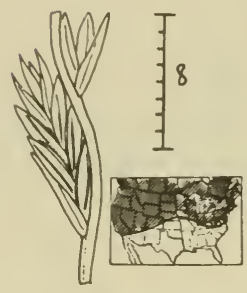

Figure 160

Winter annual or short-lived perennial; culms $30-60 \mathrm{~cm}$. tall; leaves dark green. The lemmas are awnless or nearly so. Ryegrass is much used in lawn seed mixtures, since the seed germinates rapidly and gives a green turf quickly, but the plants tend to die out when hot weather arrives. Lawns, fields, waste places, stream banks. Widely distributed through the U. S. This species and the variety listed below furnish good cool season forage. Introduced from Europe. May-July.

Variety italicum Parn. (ANNUAL RYEGRASS). This is barely distinct from the preceding species. It tends to have larger stature, more florets per spikelet, and awned lemmas, but there are many intermediates.

Lolium temulentum L. (DARNEL). Darnel may be recognized by the very long glume, which exceeds the tip of the uppermost lemma. The lemmas are awned. Weed in grainfields and waste places, especially on the Pacific Coast and in the Southeast. This species is sometimes poisonous to livestock and human beings when eaten. Introduced from Europe.

4a. Spikelets with 3 or more florets; lemmas without stout bristles on

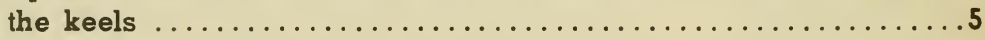

4b. Spikelets with 2 florets; lemmas bearing short, stiff bristles along the keel; cultivated annual. Fig. 161.

RYE

Secale cereale L.

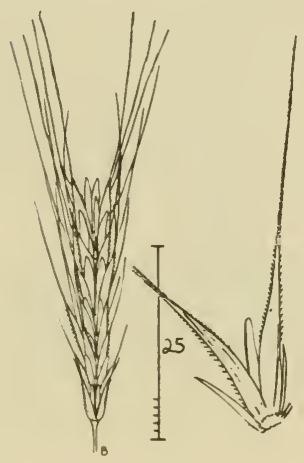

Rye resembles wheat in general appearance, but has a more slender spike. The lemmas are strongly V-shaped in cross section and have rows of vicious, upwardly-pointed barbs along keel and margins. Rye culture is confined mostly to the northern states. The plants may be found scattered along roads and in waste places in regions where it is grown. Summer. Introduced from Europe. Elongated blackish horns protruding from spikelets are ergot, a poisonous fungus used in medicine.

Figure 161 
5a. Glumes lanceolate, acute, more than twice as long as wide; grain remaining inclosed by the lemma and palea; plants perennial....6

5b. Glumes broadly ovate, blunt, less than twice as long as wide; grain falling free of the lemma and palea; cultivated annual. Fig. 162. WHEAT

Triticum aestivum L.

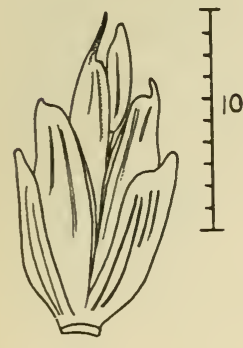

Figure 162

Wheat is the most extensively cultivated of the small grains and may be found growing in fields, waste places and roadsides as the result of seed being scattered accidentally. Some varieties of wheat have awned lemmas, others are awnless. Two primitive kinds of wheat, EMMER and SPELT, have spikes with a brittle rachis which breaks into individual joints at maturity. Both are occasionally grown as feed grains in dry regions. All introduced from the Old World.

6a. Plants producing creeping rhizomes..................

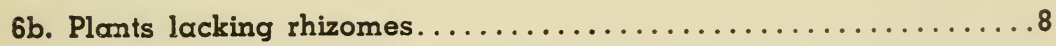

7a. Leaves bluish glaucous, often inrolled; upper leaf surface furrowed, with 7-14 ridges across the width. Fig. 163.

WESTERN WHEATGRASS Agropyron smithii Rydb.

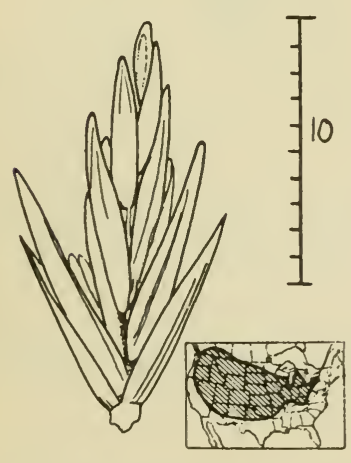

Figure 163

Perennial; culms $30-60 \mathrm{~cm}$. tall; leaves heavily glaucous, so that patches of the plants have a conspicuous blue or silvery color when viewed from $\alpha$ distance. Spikes slender, with erect spikelets. This is essentially $\alpha$ plant of the mountain and plains states of the West, but is occasionally found farther east. In the western parts of its range it is a source of forage on moist alkaline soil. Farther east, it grows on dry uplands, railroad embankments, etc. JuneAugust. 
7b. Leaves flat, usually green; upper surface of blades finely nerved, with 25-40 nerves across the width. Fig. 164. QUACKGRASS Agropyron repens (L.) Beauv.

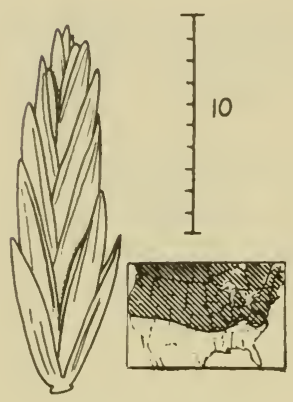

Figure 164

Perennial; with extensive creeping rhizomes; culms $50-100 \mathrm{~cm}$. tall; leaves flat, green, often hairy on the upper surface; spike slender, with erect spikelets. Some of the plants have awned lemmas. Quackgrass is one of the worst grass weeds in the northern states. It produces good forage but is not intentionally planted as a crop. Waste ground, roadsides, fields and meadows. May-July. Introduced from Europe.

8a. Spikelets erect, pressed against the rachis; rachis joints at least

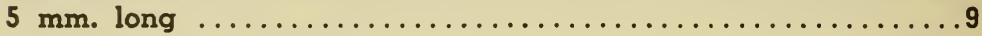

8b. Spikelets spreading away from the rachis, overlapping; rachis joints about $1 \mathrm{~mm}$. long. Fig. 165.

CRESTED WHEATGRASS Agropyron desertorum (Fisch.) Schult.

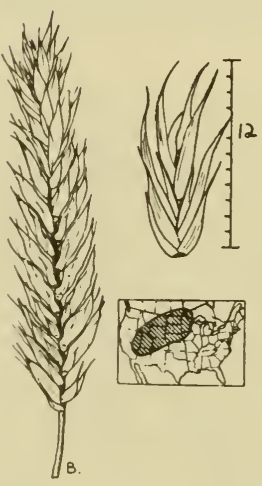

Perennial; tufted; culms $60-100 \mathrm{~cm}$. tall. The strongly divergent spikelets distinguish this species from all others of this genus. Crested wheatgrass is a recent introduction from the Old World and has proved very useful for regrassing abandoned crop lands and depleted ranges in the northern great plains states. A valuable forage species. June-August. Formerly known as Agropyron cristatum. 
9a. Lemmas awnless or with straight awns. Fig. 166.

Agropyron trachycaulum (Link) Steud.

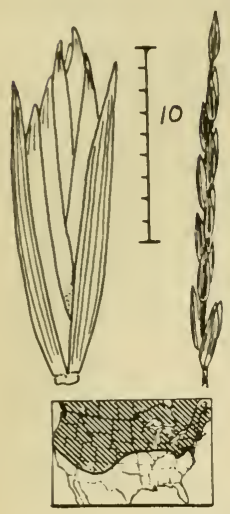

Figure 166

Perennial; tufted; culms $50-100 \mathrm{~cm}$. tall; spikes and spikelets slender; glumes conspicuously nerved. Awned and awnless forms occur, often in the same stand of plants. This is an important forage species in the western mountains. Moist grassland and open woods. As here discussed, this species includes what are called $\bar{A}$. pauciflorum (awnless) and $\bar{A}$. subsecundum (awned). June-September.

9b. Lemmas with strongly bent awns. Fig. 167 .

BLUEBUNCH WHEATGRASS Agropyron spicatum (Pursh) S. \& S.

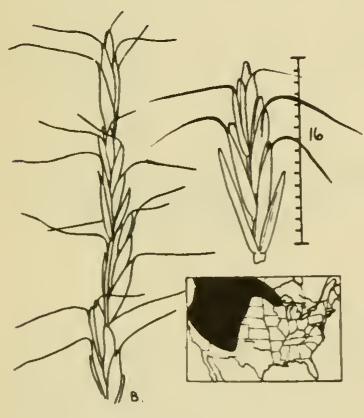

Figure 167

Perennial; tufted; culms $60-100 \mathrm{~cm}$. tall. The spikes are slender and delicate. Sheaths smooth; blades $1-4 \mathrm{~mm}$. wide, hairy on the upper surface. This species is one of the most abundant and important forage species of the northwestern states, and is readily eaten at all seasons and by all kinds of livestock. Dry plains and open mountain slopes. May-Āugust.

10a. Spikelets with 1 floret; 3 spikelets at each node of the rachis, the lateral pair sometimes reduced to awns................11

10b. Spikelets with 2 or more florets, 2 or more spikelets at some or all nodes; all spikelets alike and fertile................13

11a. Rachis of spikes separating at maturity into individual joints, each bearing 3 spikelets; wild plants....................... 
11b. Rachis of spikes not separating into joints; cultivated annual. Fig. 168.

BARLEY

Hordeum vulgare L.

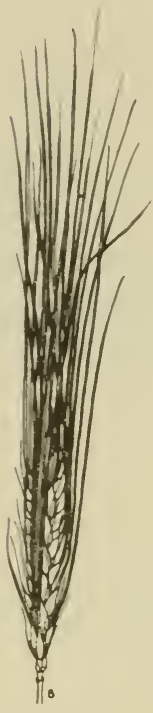

Annual; tufted; culms usually $60-120 \mathrm{~cm}$. tall; leaf blades flat, usually 5-15 $\mathrm{mm}$. wide, with prominent auricles; spikes stiff and erect; spikelets 3 at each node of the rachis; each spikelet with a single fertile floret; glumes awned; lemma with a stout awn, usually $10-15 \mathrm{~cm}$. long and very scabrous; rachilla prolonged behind the palea as a small bristle. In the hooded barleys, the lemmas lack awns but bear minute abortive extra lemmas at their tips, in inverted position. Common strains of barley are 6-rowed, that is, all 3 spikelets at each node develop grains. There are also 2-rowed barleys, in which only the central spikelet of each trio develops a grain. Barley is cultivated for the grain, which is used for human food (pearl barley, cereals), for production of malt, and for livestock feed. It is grown principally in the Middle West and in the Great Valley of California. Stray plants may grow from scattered seed, but barley is never found growing as a truly wild plant.

Figure 168

12a. Awns mostly 5-8 cm. long: plants perennial. Fig. 169. FOXTAIL BARLEY

Hordeum jubatum L.

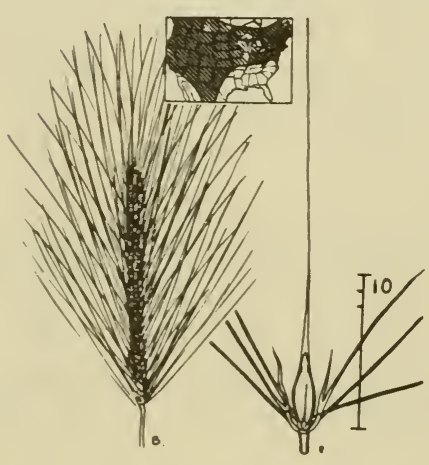

Figure. 169

Tufted; culms $30-60 \mathrm{~cm}$. tall. The bushy spikes are $5-10 \mathrm{~cm}$. long, and because of the spreading awns, about as wide. When still fresh, the awns often have a purplish or pink sheen. When the spikes are ripe, they break up into segments, each with a sharp-edged rachis joint at its base, and a trio of spikelets at its apex. Only the central spikelet is fertile, and the lateral two are reduced to long awns. The spike-segments are able to penetrate clothing, wool, or flesh, causing puncture wounds, espe- 
cially around the faces of animals. For this reason, foxtail barley is undesirable as a forage plant. Open ground, mostly in the midwestern and western states. May-August.

12b. Awns less than $2 \mathrm{~cm}$. long; plants annual. Fig. 170 . LITTLE BARLEY

Hordeum pusillum Nutt.

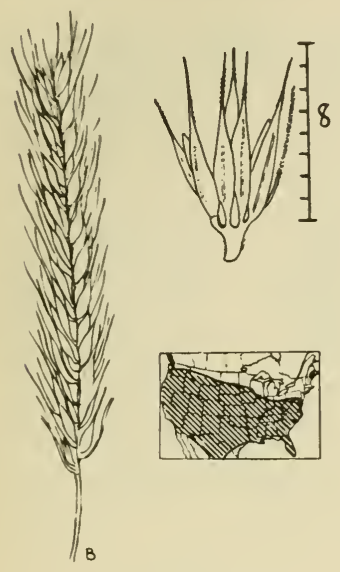

Figure 170

Annual; culms $10-35 \mathrm{~cm}$. tall, in small tufts. Both glumes of the central spikelet and the inner one of each lateral spikelet are broadened above the base. The plants furnish some early season forage, but are rejected by livestock after the spikes emerge. Plains and open ground; common in the Middle West and westward. February-July.

Hordeum brachyantherum Nevski is similar, but all of the glumes are narrow. Western mountain states, not common in the East. Introduced from Europe.

Hordeum leporinum Link has thicker spikes which are nearly square in cross section and partially hidden in the uppermost sheath. Glumes of the central spikelet hairy on the edges. Mostly in the plains and mountain states. Introduced from Europe.

13a. Glumes nearly as long as the lowermost floret; spikelets erect, pressed against the rachis........................

13b. Glumes very short or lacking; spikelets spreading at right angles to the rachis. Fig. 171.

\section{BOTTLEBRUSH}

Hystrix patula Moench

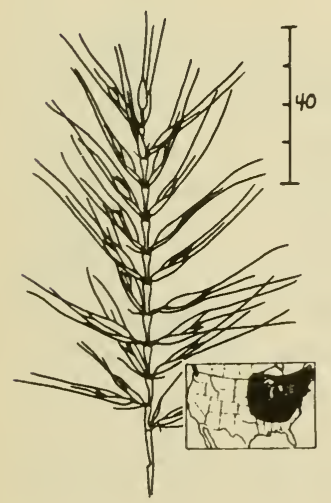

Perennial, in small tufts; culms slender, $60-120 \mathrm{~cm}$. tall. Spikes $8-15 \mathrm{~cm}$. long, very open, because of the spreading spikelets. Leaf sheaths smooth or hairy; blades usually 7-15 $\mathrm{mm}$. wide. This is a characteristic grass of damp woodlands throughout the eastern wooded sections of the country. In var. bigeloviana (Fern.) Deam, the lemmas are hairy. June-August.

Figure 171 
14b. Rachis of spikes breaking up into individual joints, each bearing 2 spikelets, when ripe. Fig. 172.

SQUIRRELTAIL

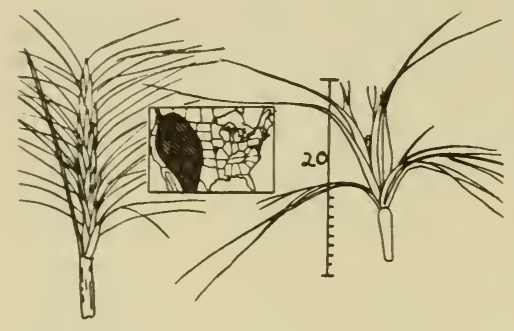

Figure 172
Sitanion hystrix (Nutt.) J. G. Smith

Perennial; tufted; culms $10-50$ $\mathrm{cm}$. tall, erect or spreading. The glumes bear one or two long, bent awns. The plants resemble Hordeum jubatum but the several florets per spikelet and two spikelets per node separate it from that species. The rachis joints bearing the awned spikelets, may penetrate the facial parts of grazing animals, causing serious inflammation, pink eye, etc. Fair forage when seed heads are not present. Dry woods and grasslands. April-September.

Sitanion jubatum J. G. Smith is similar but has three or more awns on each glume. Intermountain and Pacific Coast States.

$15 a$. Plants lacking rhizomes or rarely with short, thick ones......16

15b. Plants producing slender creeping rhizomes; ligule $1 \mathrm{~mm}$. long. Fig. 173.

Elymus triticoides Buckl.

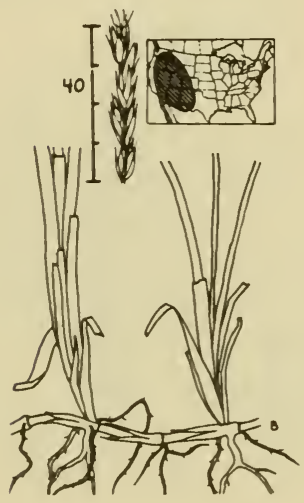

Perennial; culms usually $60-120 \mathrm{~cm}$. tall, single or in small tufts, forming large patches by means of the long, slender rhizomes. The leaves are harsh, stiff, bluish-glaucous and often rolled. Damp or saline soils, open ground. Sometimes part of the spike will have only a single spikelet at a node. Seven other species of Elymus produce extensive rhizomes. They are mostly plants of sand dunes along the oceans or in river valleys. May-August.

Figure 173 
16a. Glumes very narrow, widest at the base and tapering upward, less

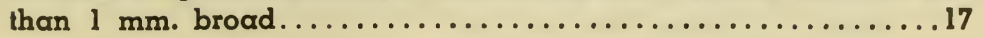

16b. Glumes flattened, wider near the middle than at the base, the middle portions with several nerves.................. 18

17a. Lemmas awnless or with awns shorter than the body of the lemma; plants of the Great Plains and western mountains and deserts. Fig. 174.

GIANT WILD RYE

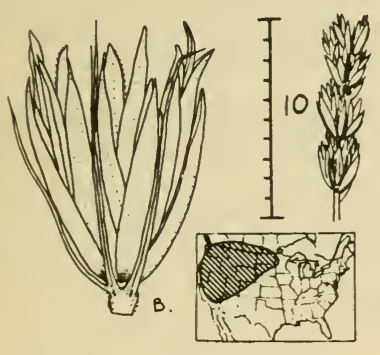

Figure 174

Elymus cinereus Scribn. \& Merr.

Perennial; tufted; rarely with short, thick rhizomes; culms about $1 \mathrm{~m}$. tall; leaves thick, stiff, flat or rolled; ligules 3-6 mm. long; spikes $15-30 \mathrm{~cm}$. long. This is an important forage grass of dry plains, sand hills, and ditches in the western states. May-August.

Elymus condensatus Presl is a very tall species, up to $3 \mathrm{~m}$. high, with large, often compound spikes, up to $50 \mathrm{~cm}$. long and $3 \mathrm{~cm}$. thick. It grows along the Pacific sea beaches in California.

17b. Lemmas with awns at least as long as the body: plants of woodlands; eastern states and westward to Wyoming and Texas. Fig. 175.

Elymus villosus Muhl.

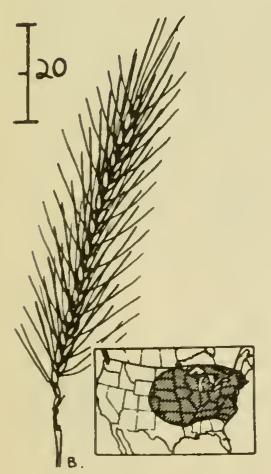

Perennial; tufted; culms slender, $60-100 \mathrm{~cm}$. tall; leaf blades thin and dark green, their upper surfaces velvety to the touch; spikes 5-12 $\mathrm{cm}$. long; spikelets usually densely hairy; glumes 12-20 $\mathrm{mm}$. long; lemmas 7-9 $\mathrm{mm}$. long, with an awn $1-3 \mathrm{~cm}$. long. Stream banks, thickets, and moist woods. June-August.

Figure 175 
18a. Spikes loose and curved; awns strongly recurved when dry: bases of glumes thin and flat. Fig. 176.

CANADA WILD RYE

Elymus canadensis L.

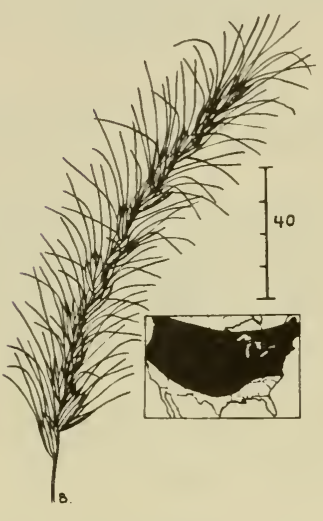

Figure 176

Perennial; tufted; culms erect or arching, bearing large, bristly spikes up to $25 \mathrm{~cm}$. long. The lemmas are rather coarsely hairy. Canada wild rye is our most widespread species and is common over much of its range. It has been experimentally planted for forage production in the Middle West. Prairies, open ground, rocky banks and open woods. July-September.

Elymus riparius Wiegand is very similar but has awns which are straight even when mature and dry. The lemmas are scabrous, not hairy as in $E$. canadensis. Quebec to North Carolina, west to Nebraska and Arkansas.

18b. Spikes stiff and straight; awns straight; bases of glumes round in cross section, hard and smooth. Fig. 177.

VIRGINIA WILD RYE

Elymus virginicus L.

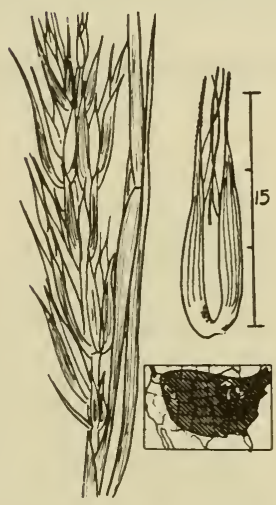

Perennial; tufted; culms stiffly erect, 60$120 \mathrm{~cm}$. tall; the base of the spike often hidden in the uppermost sheath. The "bowlegged" glumes are a good mark of recognition. Awned and awnless forms, as well as forms with smooth or hairy lemmas, are known. The plants are extremely variable in size and growth habit. The bases of the glumes are usually yellowish. Woods, thickets, stream banks, open ground. June-September. 


\title{
TRIBE IV. AVENEAE
}

la. Spikelets disarticulating above the glumes..............

1b. Spikelets disarticulating below the glumes.............

2a. Lemmas with 9 awns each....See Fig. 41 (Enneapogon desvauxii).

2b. Lemmas with a single awn $\ldots \ldots \ldots \ldots \ldots \ldots \ldots \ldots \ldots$

3a. Spikelets (excluding awns) $9 \mathrm{~mm}$. long or shorter..........

3b. Spikelets over $1 \mathrm{~cm}$. long......................

4a. Lemmas bearing an awn on the back (or if awnless, with slender

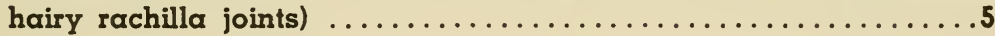

4b. Lemmas awnless or with a very short awn arising at the split tip of the lemma: rachilla joints very short. Fig. 178.

JUNEGRASS

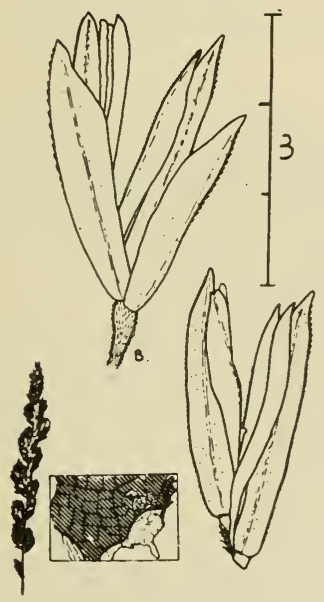

Figure 178

Koeleria cristata (L.) Pers.

\begin{abstract}
Perennial; tufted; culms $30-60 \mathrm{~cm}$. tall; panicles yellowish or silvery in color, narrowly cylindrical or somewhat lobed. At blooming time the branches spread but later close up again. Spikelets with 2-4 florets. Junegrass is one of the most widely distributed of American grasses. Dry or sandy soil; prairies or open woods. Also found in Eurasia. June-September.
\end{abstract}

5a. All florets alike and perfect: spikelets $2-6 \mathrm{~mm}$. long.......6 
5b. Lower floret staminate, with a bent, protruding awn; upper floret perfect, with a short straight awn; spikelets $7-9 \mathrm{~mm}$. long. Fig. 179.

TALL OATGRASS Arrhenatherum elatius (L.) Mert. \& Koch

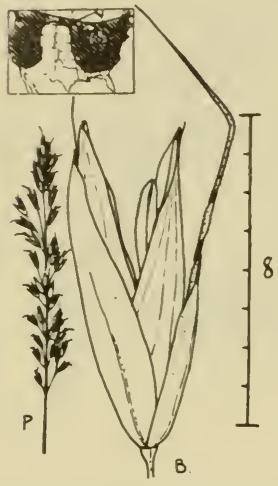

Figure 179

Perennial; tufted; culms $1-1.5 \mathrm{~m}$. tall; leaf blades 5-10 mm. wide; panicles narrow and elongated, but with spreading short branches, 15-30 cm. long; glumes thin and somewhat translucent. Rarely both florets have bent awns. Tall oatgrass is cultivated in the northern states as a meadow grass and has freely escaped to roadsides and waste ground. May - September. Introduced from Europe.

6a. Awn attached near the base of the lemma...............

$6 \mathrm{~b}$. Awn attached above the middle of the lemma or absent......8

7a. Rachilla prolonged beyond the base of the upper floret as a minute hairy bristle. Fig. 180.

HAIRGRASS

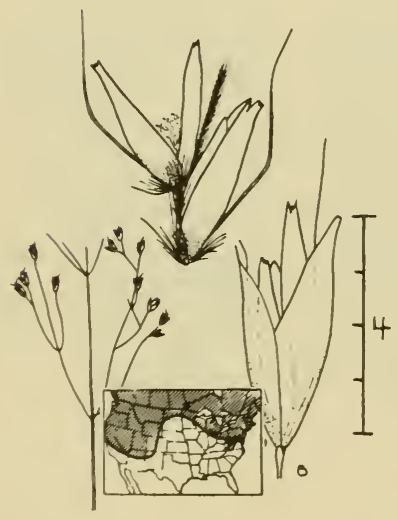

Figure 180
Deschampsia caespitosa (L.) Beauv.

Perennial; tufted; culms slender, $60-120 \mathrm{~cm}$. tall; leaves flat and scabrous, mostly at the base of the plants, 1-4 mm. wide; panicles open, delicate; spikelets often purple. The awns are nearly hidden within the glumes. The lemmas have several minute teeth at their tips. Bogs, wet ground, mountain meadows. An important forage grass in the West. May -July.

Deschampsia flexuosa (L.) Trin. is similar but the awns are strongly bent and protrude from the spikelets. Leaf blades fine and hair-like. Arctic North America, southward to Minnesota and Michigan and southward

in the Appalachion Mts. to Georgia; Arkansas and Oklahoma. 
7b. Rachilla not prolonged beyond the base of the upper floret. Fig. 181.

SILVER HAIRGRASS

Aira caryophyllea L.

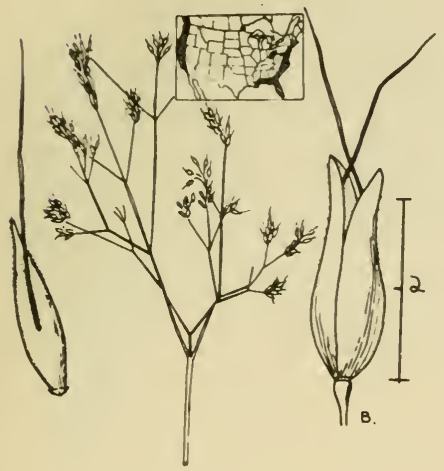

Annual; tufted; culms $10-35 \mathrm{~cm}$. tall. The plants look like delicate little trees with open crowns. The silvery spikelets are closely clustered at the tips of the branches. Dry ground, mostly in the Atlantic and Pacific coastal regions. Introduced from Europe. April-July.

Figure 181

8a. Spikelets disarticulating above the glumes..............

8b. Spikelets disarticulating below the glumes and falling entire. Fig. 182.

Trisetum pennsylvanicum (L.) Beauv.

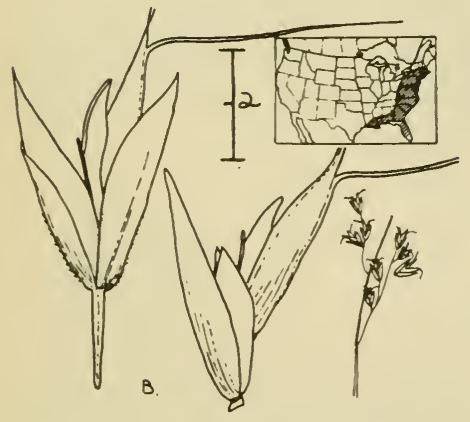

Figure 182

Perennial; culms slender and weak, $50-100 \mathrm{~cm}$. tall; tufted. The spikelets are very flat and fall with about half of the pedicel attached. Meadows, swamps, and wet ground. May-June.

Trisetum interruptum Buckl. has similar spikelets but a dense, spikelike panicle. Open dry plains, Texas to Colorado and Arrizona. March-May. 
9a. Awn short, concealed within the glumes, or absent. Fig. 183.

Trisetum woltii Vasey

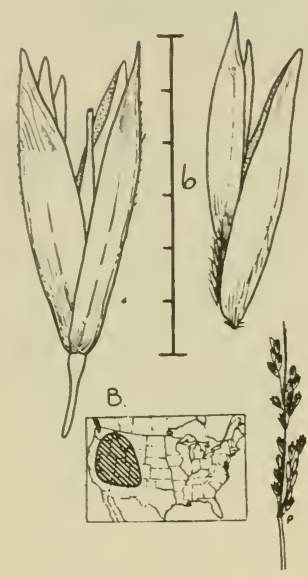

Perennial; tufted or sometimes with short rhizomes; culms $50-100 \mathrm{~cm}$. tall; leaf blades flat, 2-4 mm. wide, scabrous on the upper surface; panicles dense, cylindrical, yellowish. An important forage grass in moist mountain meadows at mid-altitudes in the western mountains. July-September.

Figure 183

9b. Awn protruding from the glumes, bent and twisted. Fig. 184. SPIRE TRISETUM

Trisetum spicatum (L.) Richt.

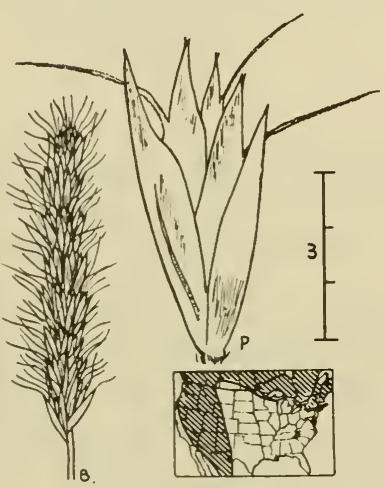

Figure 184

Perennial; tufted; culms $15-50 \mathrm{~cm}$. tall; foliage smooth or finely hairy; panicles spikelike, dense, shaggy with many protruding awns, purplish or golden. An important forage grass at high altitudes, on slopes and in mountain meadows in the western mountains. The plants furnish good forage throughout the growing season, especially for cattle and horses. June-Auqust.

10a. Awn attached between 2 teeth at the tip of the lemma; spikelets

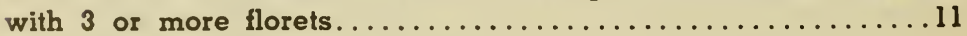


10b. Awn attached on the back of the lemma; spikelets with 2 or 3 florets. Fig. 185.

WILD OATS

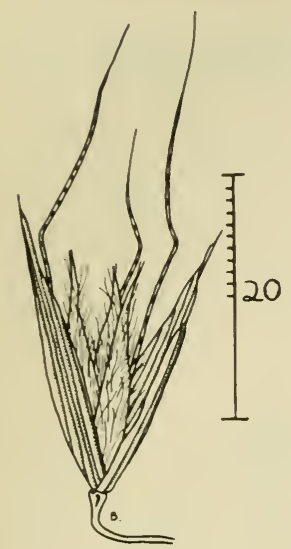

Figure 185

Avena fatua L.

Annual; culms usually $30-100 \mathrm{~cm}$. tall, in small tufts; panicles open, up to $30 \mathrm{~cm}$. long. The spikelets when ripe are open, bell-shaped, with conspicuous protruding bent awns. The scar at the base of the floret is circular and prominent and is usually called a "sucker mouth." Wild oats is distinguished by the hairy lemmas, prominent awns' and the sucker mouth. It is widely dispersed in the United States but is most common in the Pacific Coast States, where it is a prevalent weed and is sometimes cut for hay. May-August.

Avena sativa L. (CULTIVATED OATS) Fig. 186 differs from wild oats in having lemmas which are glabrous except on the callus, no sucker mouth, and weak, usually straight awns. Widely cultivated and growing from scattered seed on roadsides and waste ground.

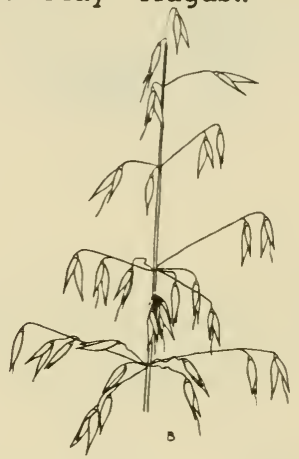

Figure 186

11a. Lemmas glabrous except for the hairy edges and callus; plants of the western mountains. Fig. 187.

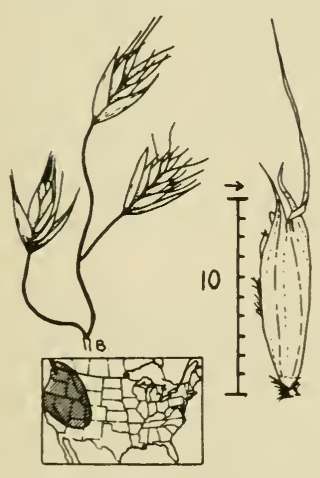

Figure 187

Danthonia californica Bolander Perennial; tufted; culms $30-80 \mathrm{~cm}$. tall, tending to break at the joints. The panicle is small, consisting of 2-5 large spikelets on spreading pedicels. In this and other species of Danthonia, the lower sheaths may be swollen and contain slender, much distorted cleistogamous spikelets called "cleistogenes." The culms break off just below the node where a cleistogene is present. Meadows and open woods. Of some value for forage. May-August.

Danthonia intermedia Vasey has the few spikelets borne in a dense, tuft-like panicle, 2-5 cm long. Arctic North America, southward to Michigan and at high altitudes in western states. Grazed by livestock. July-September. 
11b. Lemmas hairy on the back as well as the edges; plants widespread in the United States. Fig. 188.

POVERTY OATGRASS Danthonia spicata (L.) Beauv.

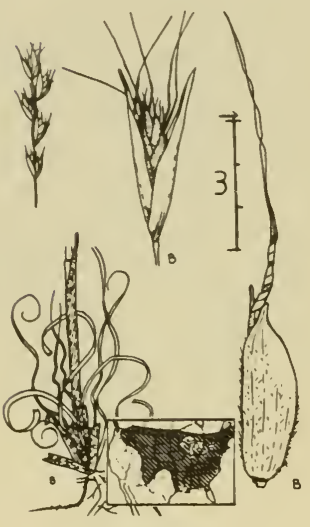

Figure 188

Perennial; tufted; culms usually 20-50 $\mathrm{cm}$. tall. Most of the short, curly leaves are borne in a basal tuft. Their ligules are under $1 \mathrm{~mm}$. long. Panicles short, 2-5 cm. long, with ascending branches. Poverty oats makes gray-green mats or sods on dry, sterile soils in the open or in thin woods. Forage value very low. Cleistogenes may be present, as in $D$. californica. May-September.

Danthonia compressa Austin has panicles with spreading branches. The ligules of the lower leaves are $2-5 \mathrm{~mm}$. long. Open ground and in moist or dry woods, mostly in the Appalachian Mountains; Quebec to Georgia. June-July.

12a. One or both lemmas with awns; glumes similar in shape.....13 12b. Lemmas without awns; first glume linear; second glume obovate, very broad. Fig. 189.

WEDGEGRASS

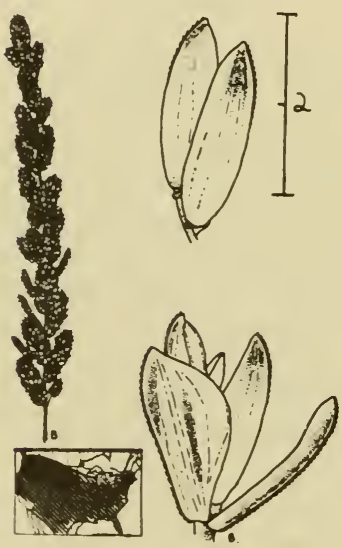

Figure 189
Sphenopholis obtusata (Michx.) Scribn.

Perennial; tufted; culms $30-100 \mathrm{~cm}$. tall; panicles dense and cylindrical, the branches spreading somewhat at flowering time. The peculiarly shaped glumes are the most characteristic thing about the wedgegrasses. In this species, the second glume is $2-2.5$ times longer than its folded width. Open ground, thin woods, wet spots. Succulent and probably good feed, but not occurring in dense stands. MayAugust.

Sphenopholis intermedia Rydb. has a looser, more open panicle; the second glume is $3-4$ times longer than the folded width. Throughout the United States and southern Canada. May-July.

Sphenopholis nitida (Biehler) Scribn. has a slender, open panicle. The upper lemma of each spikelet is visibly scabrous under a lens. Woods, eastern states to Illinois and Texas. 
13a. Spikelets disarticulating in the pedicel, falling with the stub of the pedicel attached..... See Fig. 182 (Trisetum pennsylvanicum)

13b. Spikelets disarticulating just below the hairy glumes. Fig. 190. VELVET GRASS Holcus lanatus L.

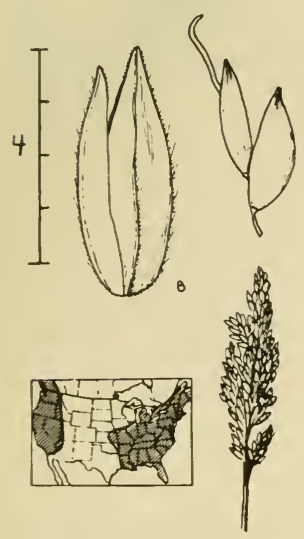

Perennial; tufted; culms $30-60 \mathrm{~cm}$. tall; panicles elliptical, closely flowered. The spikelets have an awnless perfect lower floret and a staminate second floret with a short awn. The entire plant is softly velvety to the touch. Open moist ground, meadows, thickets. Velvet grass was imported for forage but is rarely cultivated now. The plant has been known to kill livestock under some conditions. Forage value low. Introduced from Europe. June-August.

Figure 190

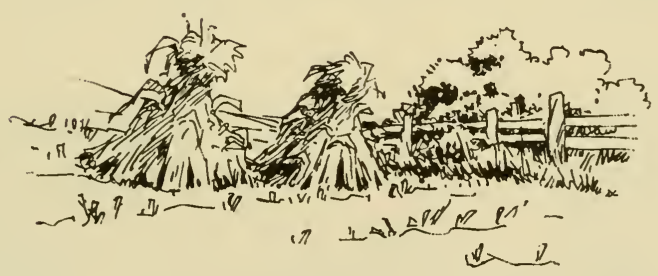




\section{TRIBE V. AGROSTIDEAE}

1a. Spikelets disarticulating below the glumes and falling whole $\ldots 2$

lb. Spikelets disarticulating above the glumes, the floret falling.....8

2a. Glumes with awns or protruding midribs $\ldots \ldots \ldots \ldots \ldots \ldots$

2b. Glumes without awns; midrib not protruding $\ldots \ldots \ldots \ldots \ldots \ldots$

3a. Both glumes with single awns; floret smooth and shining. . . . .

3b. First glume with 2 or 3 awns; floret hairy. Fig. 191. WOLFTAIL

Lycurus phleoides H. B. K.

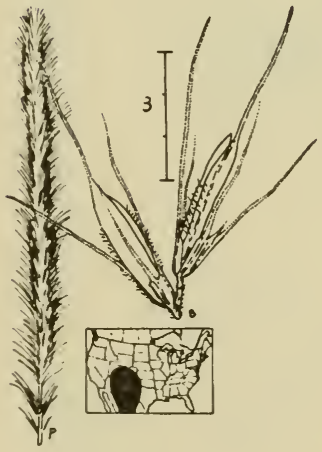

Figure 191

Perennial; tufted; culms $20-60 \mathrm{~cm}$. tall. The dense, spikelike, bristly panicles are usually gray in color. The spikelets fall in pairs, one of each pair being on a longer stalk than the other. The lower spikelet is staminate and the upper one perfect. Open brushy hillsides and ponderosa pine forests, $1400-2600 \mathrm{~m}$. elevation. A valuable forage grass, grazed especially in spring. July-September.

4a. Awn straight and stiff, shorter than the lemma.........25a 
4b. Awn fine and delicate, about 3-4 times as long as the lemma; spikelets $2 \mathrm{~mm}$. long. Fig. 192.

RABBITFOOT GRASS Polypogon monspeliensis (L.) Desf.

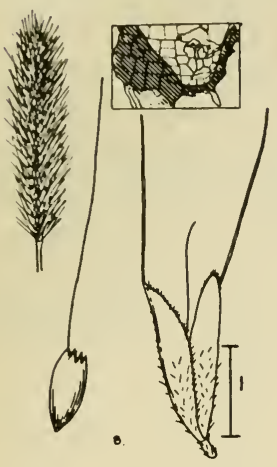

Figure 192

Annual; tufted; usually $15-50 \mathrm{~cm}$. tall; panicles dense, often somewhat lobed, densely covered with soft, silky yellowish awns. Rabbitfoot grass is rather widely distributed in the United States, but is most common in the West, at low altitudes. Frequently found on seepy wet ground around springs or on banks of streams. Weedy; forage value low. May-October. Introduced from Europe.

5a. Panicle dense, cylindrical and spikelike...............

5b. Panicle open, with spreading or draoping branches.........

6a. Spikelets about $5 \mathrm{~mm}$. long: panicles $7-10 \mathrm{~mm}$. in diameter; awns protruding. Fig. 193.

MEADOW FOXTAIL

Alopecurus pratensis L.

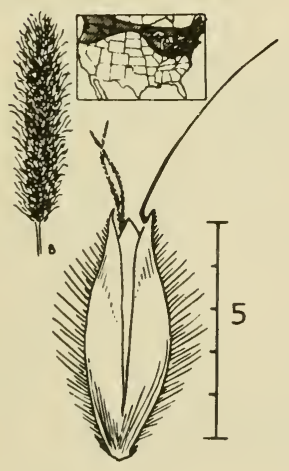

Perennial; tufted; culms $30-80 \mathrm{~cm}$. tall. The panicles resemble those of timothy but the lemmas have protruding bent awns and the spikelets fall off at a touch when ripe. This genus is one of very few having united glumes. Meadow foxtail is sometimes cultivated as a forage grass in the northern states and found growing wild in meadows and waste ground. May-June. Introduced from Europe. 
6b. Spikelets $2-3 \mathrm{~mm}$. long; panicles $4-5 \mathrm{~mm}$. in diameter; awns concealed in the glumes. Fig. 194.

Alopecurus aequalis Sobol.

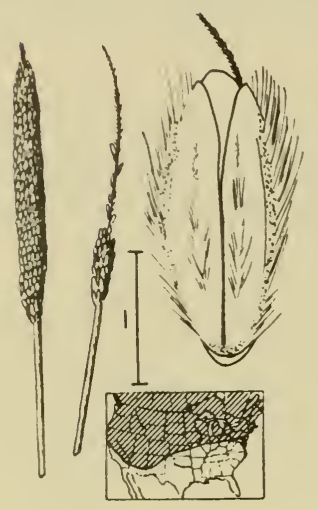

Perennial; culms weak and sprawling, 15-60 cm. long; leaf blades $1-4 \mathrm{~mm}$. wide; panicles cylindrical, shattering very readily; $2-7 \mathrm{~cm}$. long. The plants are frequent on wet ground in swamps or along small streams. Succulent and probably good forage. May-June.

Figure 194

7a. Glumes about $1 / 3$ as long as the floret; cultivated annual; aquatic (Rice). See Fig 276. (Oryza sativa).

7b. Glumes about as long as the floret; wild plants, not aquatic. Fig. 195.

WOODREED

Cinna arundinacea L.

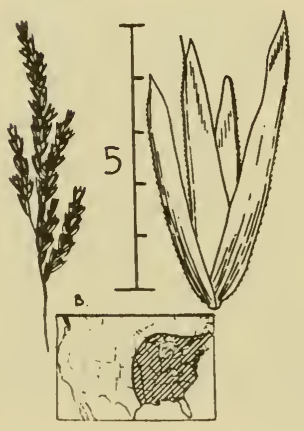

Figure 195

Perennial; culms in small tufts, 100-150 $\mathrm{cm}$. tall; panicles large, $15-30 \mathrm{~cm}$. long, drooping, the very flat spikelets shining, overlapping. The leaves are sometimes over 1 $\mathrm{cm}$. wide. This common woodland grass is found in moist forests. August-October.

Cinna latifolia (Trevir.) Griseb. has smaller spikelets, less than $4 \mathrm{~mm}$. long. Arctic America, southward through most of the United States except the southeastern states. 
8a. Edges of leaf sheaths united. See Fig. 94 (Melica imperfecta).

8b. Edges of leaf sheaths overlapping, not united............

9a. Floret not dorsally compressed; awn present or absent......10

9b. Floret dorsally compressed, the lemma and palea stiff, smooth and shining: awn absent. Fig. 196.

Milium effusum L.

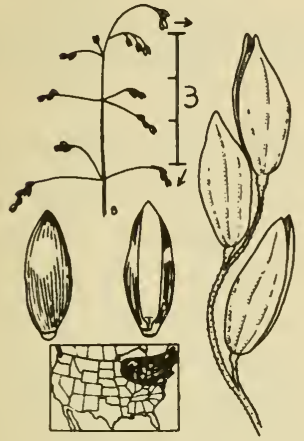

Figure 196

Perennial; culms in small tufts, up to 150 cm. tall. Foliage smooth, the leaf blades 8$15 \mathrm{~mm}$. wide. The panicles are $10-20 \mathrm{~cm}$. long, very open, cylindrical, with short drooping branches. The dorsally compressed floret greatly resembles that of species of Panicum, but the disarticulation above the glumes places it with the Agrostideae. Cool, moist woods. May-July.

10a. Floret hard, round in cross section, with faint nerves; awn usually present; callus pointed, hairy. Fig. $1961 / 4 \ldots \ldots \ldots \ldots \ldots \ldots$. . . . . .

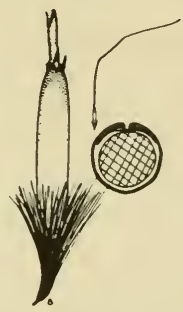

Figure $1961 / 4$

10b. Floret soft or leathery, usually more or less flattened and with evident nerves; callus not sharp pointed, either glabrous or hairy. Fig. $196 \frac{1}{2} \ldots 23$

1la. Lemma with 3 awns, the lateral two often short. .12

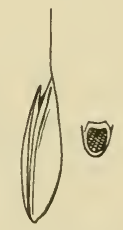

Figure $196 \frac{1 / 2}{2}$

11b. Lemma with a single awn or none................ 
12a. Central awn spirally coiled at the base..............

12b. Central awn not coiled.......................

13a. Glumes about equal in length; lateral awns about $1 / 4$ as long as the central one. Fig. 197.

Aristida dichotoma Michx.

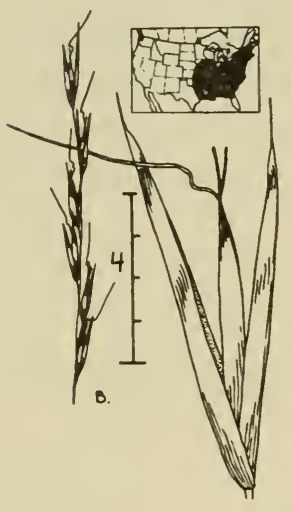

Annual; tufted, in small, shallowly-rooted clumps; culms $20-40 \mathrm{~cm}$. tall. The panicles are very slender, almost racemose. The species of Aristida are sometimes called wiregrasses or needlegrasses. They are typically grasses of depleted ranges or poor, sterile soils. This species is found on dry sandy or rocky open ground or in open sterile woods. Forage value negligible. August-October.

Figure 197

13b. Glumes unequal, the first $1 / 2$ to $3 / 4$ as long as the second. Fig. 198. Aristida basiramea Engelm.

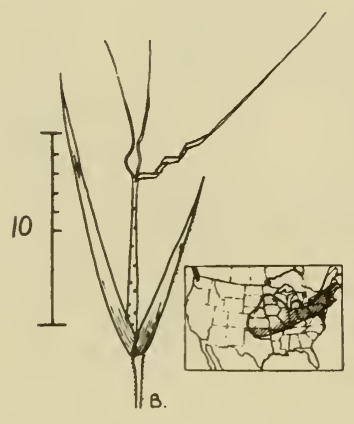

Figure 198

Annual; culms in small tufts, 30-50 $\mathrm{cm}$. tall; leaf blades harsh, $1-2 \mathrm{~mm}$. wide; panicles slender, raceme-like, 5 $-10 \mathrm{~cm}$. long, at the tips of the culms and in axils of the upper leaf sheaths. Dry sterile soil, open ground. AugustOctober.

Var. curtissii (Gray) Shinners has very short lateral awns, 2-4 mm. long. Pennsylvania and Virginia to Wisconsin, Wyoming, Colorado and Arkansas. 
14a. Glumes about equal, $2-3 \mathrm{~cm}$. long: lemma about $2 \mathrm{~cm}$. long. Fig. 199.

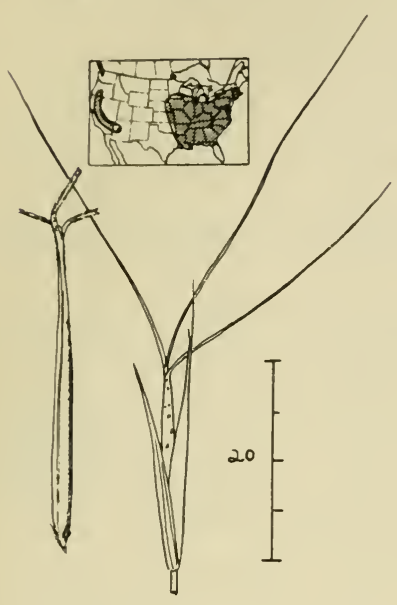

Figure 199

Aristida oligantha Michx.

Annual; tufted; culms much branched, $30-50 \mathrm{~cm}$. tall; leaf blades narrow, usually under $1 \mathrm{~mm}$. wide; panicles $10-20$ $\mathrm{cm}$. long; glumes nearly equal, $2-3 \mathrm{~cm}$. long, sometimes 3-cleft at the tip; awns 4-7 cm. long, spreading, about equal in length. The plants are wiry and almost leafless, most of the height being the bristly inflorescences. The sharp-pointed, 3-awned florets of this and other species of Aristida are great "crawlers." The pointed and backwardly-barbed callus penetrates hair or clothing easily, and every movement of the body of the host results in the floret digging in deeper, aided by the scabrous awns. Forage value negligible. Dry open ground. August-October.

14b. Glumes unequal, the first about $1 \mathrm{~cm}$. long, the second twice as long; lemma 12-15 mm. long. Fig. 200. DOGTOWN GRASS

Aristida longiseta Steud.

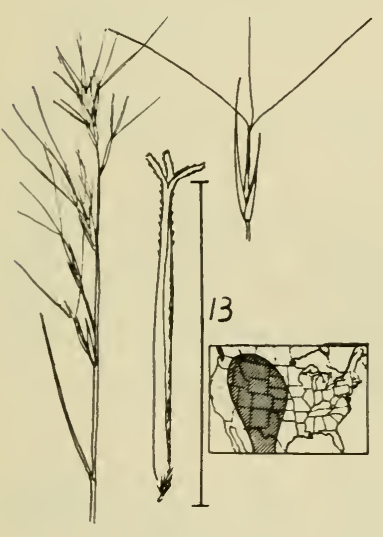

Figure 200

Perennial; in large tufts; culms 20$50 \mathrm{~cm}$. tall; panicles narrow, standing well above the leaves, appearing as a feathery mass of long, reddish awns. The awns may reach lengths of $6-8$ $\mathrm{cm}$. The narrow, stiff, straight leaves may be mostly at the base of the plant. Dogtown grass is an inferior forage species. The sharp awns and pointed callus cause the florets to pierce the facial tissues of grazing animals, causing serious infections and sometimes blindness. Dry plains and foothills, especially on thin rocky soil or bare ground. JulyOctober.

Aristida fendleriana Steud. is similar in the panicle and spikelets, but most of the leaves are crowded in dense, curly basal tufts. Widespread in the Great Plains and western mountain states.

15a. Awn bent, twisted at least near the base, firmly attached to the lemma 
15b. Awn straight or bent, (rarely absent) readily separating from the lemima when mature; floret rather short and plump........16

16a. Lemmas covered with short, appressed hairs or glabrous....17

16b. Lemmas covered with long, silky white hairs; panicle open, with spreading branches. Fig. 201.

INDIAN RICEGRASS Oryzopsis hymenoides (R. \& S.) Ricker

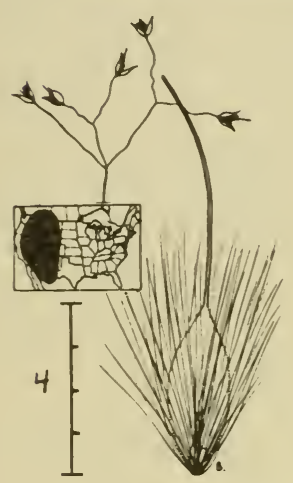

Figure 201

Perennial; culms $30-60 \mathrm{~cm}$. tall, in dense, tough tufts. The panicles are very open, with scattered spikelets on the tips of slender, zigzag pedicels. The lemmas are brownish-black, but are covered with a dense cloud of white hairs. The awns readily break away from the lemmas, and may be missing from many of the spikelets. This is one of the most valuable forage grasses in the desert areas of the West. It is especially prized for winter feed. The large seeds are nutritious feed for livestock and formerly were used as food by the Zuñi Indians. April-August.

17a. Spikelets (without the awns) 6-9 $\mathrm{mm}$. long; leaf blades flat, all at the base of the plant. Fig. 202.

Oryzopsis asperifolia Michx.

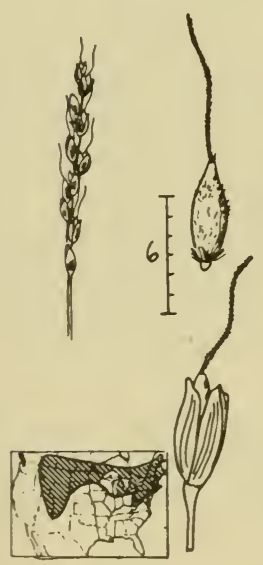

Perennial; tufted, with numerous long flat basal leaves; culms $20-70 \mathrm{~cm}$. long, usually spreading, lacking leaf blades (sheaths present). The hard cylindrical lemmas are yellowish in color. Scattered in sandy or rocky woods. May-June.

Oryzopsis racemosa (Smith) Ricker is similar in general habit, but has long upper culm leaves and short basal leaves. The lemmas are black. Quebec to Delaware, westward to Kentucky and South Dakota. June-August.

Figure 202 
17b. Spikelets (without the awn) less than $3 \mathrm{~mm}$. long: leaves threadlike; some leaf blades on the culms. Fig. 203.

Oryzopsis micrantha (Trin. \& Rupr.) Thurb.

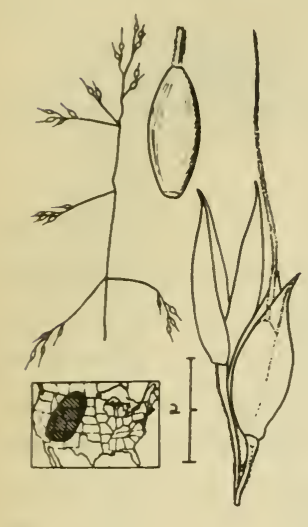

Figure 203

Perennial; in dense tufts; culms thin, 30$70 \mathrm{~cm}$. tall; leaf blades flat or rolled, less than $2 \mathrm{~mm}$. wide, scabrous; panicles $10-15 \mathrm{~cm}$. long, with slender spreading branches, the spikelets borne near the tips; glumes thin and translucent; lemmas smooth or with appressed hairs, yellow or brownish; awns readily detachable, straight, 5-10 $\mathrm{mm}$. long. Open woods and dry rocky slopes, intermediate elevations. The plants are said to have some forage value. June-July.

Oryzopsis miliacea (L.) Benth. (SMILO GRASS) has similar spikelets but broad, flat leaf blades, $8-10 \mathrm{~mm}$. wide. It is cultivated for forage in California. Introduced from Europe

18a. Lemma 5-12 mm. long, excluding the awn............

18b. Lemma 15-25 mm. long. Fig. 204. PORCUPINE GRASS

Stipa spartea Trin.

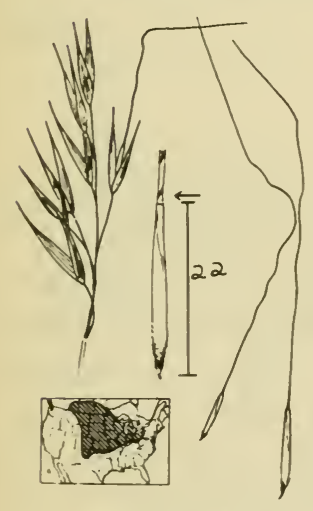

Figure 204

Perennial; culms in small hard tufts, about $1 \mathrm{~m}$. tall. The panicle is erect or nodding, with few spikelets; glumes whitish; mature lemmas brown; awns $15-20 \mathrm{~cm}$. long, with one or two sharp bends. The floret of Stipa species is a remarkable self-planting device. When it falls from the glumes, its sharp pointed callus readily penetrates the ground. The backward-pointing hairs prevent the floret from pulling out. The twisted portion of the awn coils and uncoils as the moisture content of the air changes, causing the bent arm of the awn to revolve slowly until it comes in contact with grass stems or other objects. Then the whole lemma is literally screwed down into the earth. Unfortunately the same process will occur if the florets get into wool or hair of animals, and these florets can thus cause serious puncture wounds on grazing animals, especially around the eyes, nose, and mouth. Prairies and dry open ground, mostly in the Midwest. June-July. 
19a. Lemma 8-12 mm. long; glumes $12-20 \mathrm{~mm}$. long.........20

19b. Lemma 5-6 mm. long; glumes 5-10 mm. long..........22

20a. Lemma without a smooth whitish summit.............21

20b. Lemma with a smooth whitish ring at the summit. Fig. 205. TEXAS NEEDLEGRASS

Stipa leucotricha Trin. \& Rupr.

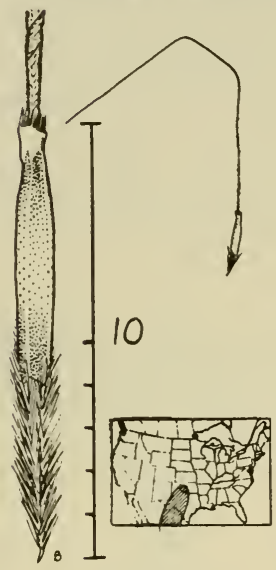

Perennial; culms $30-60 \mathrm{~cm}$. tall; leat blades $10-30 \mathrm{~cm}$. long, very narrow, rolled, rough to the touch, dark green. The awn is 6$10 \mathrm{~cm}$. long, with two bends. The lower sheaths contain very peculiar hidden spikelets (cleistogamous), lacking glumes and with a very short-awned lemma. This species begins growth very early, in late winter and early spring and is prized for winter feed. The awned florets may injure sheep. Dry plains. May-June.

Figure 205

21a. Mature lemma chocolate brown or black.............22

21b. Mature lemma pale or brownish. Fig. 206.

NEEDLE AND THREAD

Stipa comata Trin. \& Rupr.

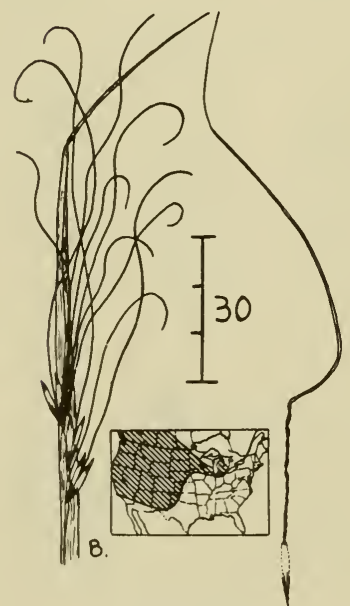

Perennial; culms in tufts, $30-60 \mathrm{~cm}$. tall. The panicle is a mass of curly awns, 10$15 \mathrm{~cm}$. long. The base of the panicle is usually partially hidden in the uppermost sheath. Needle and thread is a valuable forage grass in many parts of the West. It is grazed especially in the spring and fall, before the "needles" are formed and after they fall. Prairies, plains, and dry open mountain slopes. June-August.

Figure 206 
22a. Edges of lemma overlapping and hiding the palea; panicle elongated, spikelike, with many spikelets. Fig. 207.

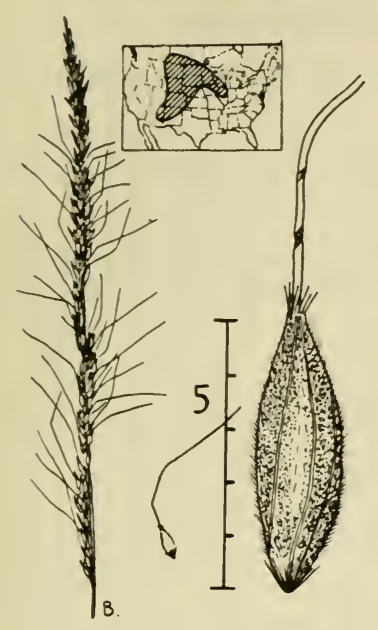

Figure 207

Stipa viridula Trin.

Perennial; culms $60-100 \mathrm{~cm}$. tall, in dense clumps; panicles slender, dense, elongated, $10-20 \mathrm{~cm}$. long. The glumes are glossy and rather translucent. Awn 2-3 cm. long, with two bends. Dry plains. This species yields good forage. June-August.

Stipa robusta Scribn. (SLEEPY GRASS) is very similar, but taller $(100-150 \mathrm{~cm})$. It has a narcotic effect on horses who graze it. Dry plains, Colorado to Texas and Arizona.

22b. Edges of lemma not meeting, turned inward, with a deep groove between the edges; panicle with spreading branches, bearing $a$ few spikelets near their tips. Fig. 208.

PINYON RICEGRASS Piptochaetium fimbriatum (H. B. K.) Hitch.

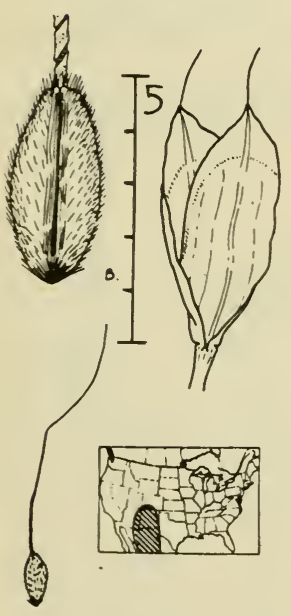

Figure 208

Perennial; culms in dense tufts, $40-80 \mathrm{~cm}$. tall; leaf blades one-third to one-half as long as the culms, mostly at the base of the plant, thread-like and curved downward; panicles 5-15 cm. long; glumes about $5 \mathrm{~mm}$. long, thin; floret dark-colored, glabrous or hairy; awns readily detachable, twice bent, $1-2$ $\mathrm{cm}$. long. Piñon ricegrass is said to be a valuable forage species. Open, rocky woods.

The genus Piptochaetium is one of the oldest known grass genera. Fossils of the florets have been collected from Miocene rock formations in the western states. 
23a. One or both glumes longer than the lemma (excluding the awn)

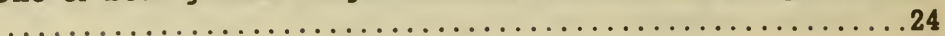

23b. Glumes shorter than or equal to the lemma in length........39

24a. Glumes both longer than the lemma, equal, strongly flattened and keeled, V-shaped in cross section....................25

24b. Glumes either unequal or not strongly keeled, never with long

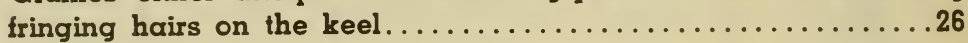

25a. Spikelets about $5 \mathrm{~mm}$. long; glumes cut square at the tip, the midnerve protruding as an awn; plants widespread, tufted. Fig. 209. TIMOTHY

$P$ hleum pratense $L$.

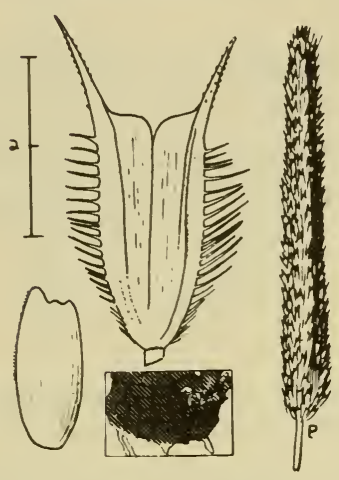

Figure 209

Perennial; tufted, the culms $50-100 \mathrm{~cm}$. tall, often with swollen, bulb-like bases. The dense, cylindrical panicles are stiff and somewhat bristly. Timothy is one of the important hay meadow grasses in the northem states, and is very widely established in the wild as well, in the moister portions of the country. June-July.

Phleum alpinum L. (ALPINE TIMOTHY), with short, plump, dark colored panicles, occurs in wet mountain meadows at high altitudes in the West and from Greenland to Alaska.

25b. Spikelets 10-20 mm. long: coarse, stiff grasses of sand beaches; rhizomes long and stiff. Fig. 210.

AMERICAN BEACHGRASS Ammophila breviligulata Fernald

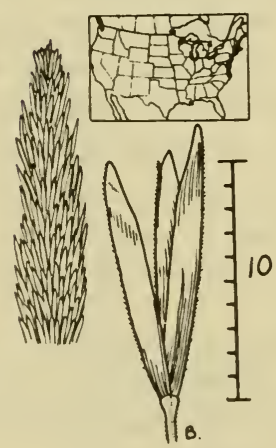

Perennial; spreading by very long, stiff rhizomes. The plants are coarse and tough. Panicles dense and cylindrical, $10-20 \mathrm{~cm}$. long. The plants are highly important sand binders' on dunes along the Atlantic Coast and on sand beaches of the Great Lakes. July-September.

Figure 210

26a. Glumes not swollen near the base................ 
26b. Glumes swollen near the base. Fig. 211.

NIT GRASS

Gastridium ventricosum (Gouan) S. \& T.

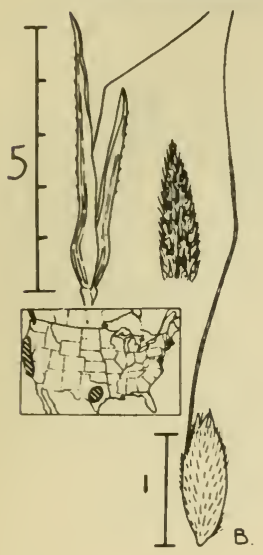

Annual; tufted, shallow-rooted; culms 20-55 cm. tall; panicles dense, cigar-shaped, with glossy silvery or yellowish spikelets. The minute floret is concealed by the glumes. Weed of fields and waste places, common on the Pacific Coast. Introduced from Europe. May -July.

Figure 211

27a. Rachilla prolonged as a short hairy bristle behind the palea (CARE). Fig. 212 ........28

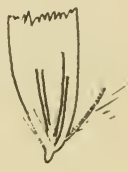

Figure 212

27b. Rachilla not prolonged behind the palea.....30

28a. Awn straight, hidden within the glumes; hairs nearly as long as

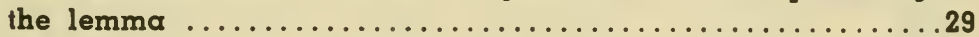

28b. Awn bent sidewise, protruding from the glumes; hairs shorter than the lemma. Fig. 213.

PINEGRASS

Calamagrostis rubescens Buckl.

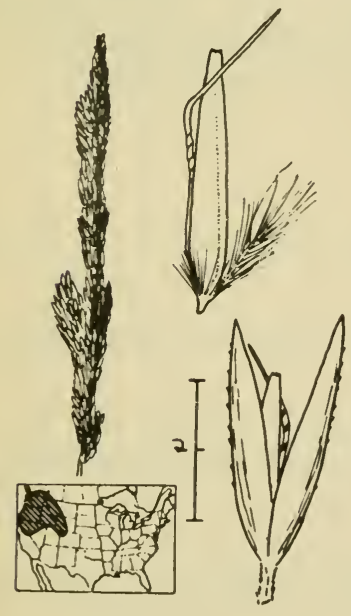

Figure 213

Perennial; culms in tufts, $60-100 \mathrm{~cm}$. tall; plants producing rhizomes; leaf blades scabrous, $2-4 \mathrm{~mm}$. wide, flat or somewhat rolled; panicles dense and cylindrical, 7-15 cm. long, pale or purplish in color; glumes $4-5 \mathrm{~mm}$. long; sterile rachilla joint about $1 \mathrm{~mm}$. long, its hairs about twice as long. While common, pinegrass is low in palatability, especially for sheep, and is little grazed except when young and green. The plants make a strong, tough turf which resists heavy grazing and trampling. Most of the reproduction is by rhizomes. Coniferous forests, up to $3300 \mathrm{~m}$. elevation. June-August. 
29a. Panicle open, pyramidal, with spreading or drooping elongated branches. Fig. 214.

BLUEJOINT

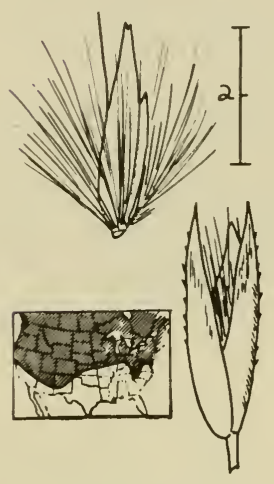

Calamagrostis canadensis (Michx.) Beauv.

Figure 214

Perennial; culms slender, in small tufts, 60 $-150 \mathrm{~cm}$. tall; plants producing many, long. creeping rhizomes. The panicles vary from rather dense to loose, pyramidal, and nodding. Bluejoint is a very widespread and common species found in marshes and wet ground. While rather tough, it furnishes a good deal of forage and is sometimes cut for marsh hay in the North Central States. June -August.

29b. Panicle dense, cylindrical, with short, erect branches. Fig. 215. Calamagrostis inexpansa Gray

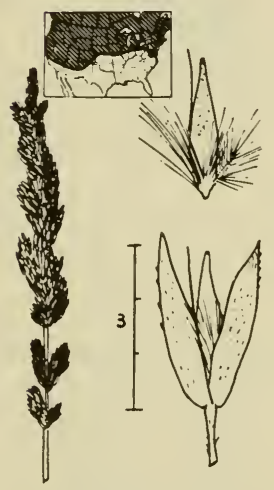

Perennial; culms in tufts, $40-120 \mathrm{~cm}$. tall; plants producing rhizomes. The dense, cylindrical panicle may be pale or purplish. The leaf blades are rough to the touch and usually rolled; ligules $4-7 \mathrm{~mm}$. long. Marshes and wet meadows, apparently sometimes on dry soil in the western mountains. June-July.

Figure 215

30a. Glumes unequal, the first shorter than the floret, the second longer .31

30b. Glumes equal, both longer than the floret; palea shorter than the lemma; tufted or rhizome-bearing plants................ 32

3la. Lemma without lozg hairs on the callus; glabrous or with appressed hairs on the back......................55 
3lb. Lemma bearing a copious tuft of white hairs attached to the callus; tall perennial with stout rhizomes. Fig. 216.

SAND REEDGRASS Calamovilfa longifolia (Hook.) Scribn.

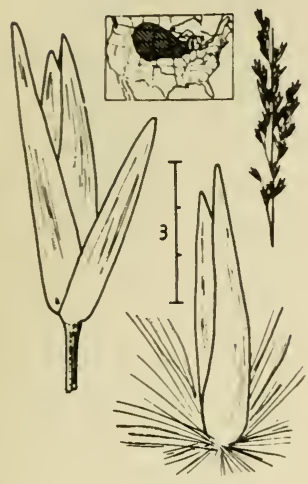

Figure 216
Perennial; culms $50-180 \mathrm{~cm}$. tall, in small tufts; plants producing long, tough, scaly rhizomes; panicles large, $15-35 \mathrm{~cm}$. long; lemmas bearing copious tufts of straight white hairs on the callus. The plants are coarse and tough, but make considerable amounts of winter feed and are sometimes cut for hay. Sandy soil, hills and plains; shores of Lake Huron and Lake Michigan. August-September.

Calamovilfa gigantea (Nutt.) Scribn. \& Merr. is similar but larger, and has hairs on the backs of the lemmas. Sand dunes of the great plains and southwestern states.

32a. Glumes with long awn-tips, or the lemmas long-awned from the tip; panicles dense; rhizomes densely covered with overlapping scales

32b. Glumes not awnedi lemmas awnless or awned from the back; panicles open or dense; rhizomes, if present, not covered with over-

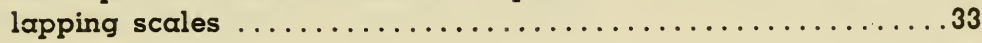

33a. Palea at least half as long as the lemma; plants often with rhizomes or stolons .34

33b. Palea absent or less than $1 / 4$ as long as the lemma; plants tufted, lacking rhizomes or stolons........................

34a. Plants with erect stems; panicles open, pyramidal..........35 
34b. Plants with creeping stolons, rooting at the nodes and forming flat mats; rhizomes absent; panicle narrow, the branches closing up after the flowering period. Fig. 217.

CREEPING BENT

Agrostis palustris Huds.

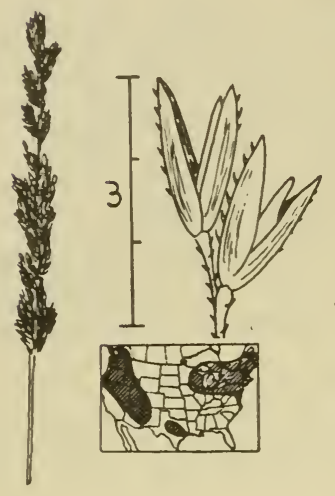

Figure 217

Perennial; low, spreading by numerous fine leafy stolons. This species is much used for golf greens and tine lawns, but requires frequent cutting and watering to produce a good turf, and the plants are subject to several serious diseases. New lawns are usually produced by planting pieces of chopped turf, which take root and spread to form a continuous sod. Reproduction by seed is also possible, but seed of many strains is very scarce or unobtainable. Various forms of this species are known as seaside bent, Coos Bay bent, Washington bent, and Metropolitan bent. Marshes, especially along seacoasts, wet ground around streams, springs, lakes, and ditches. Also known from Europe and Asia. June-September.

35a. Ligules $1-2 \mathrm{~mm}$. long; leaf blades $1-3 \mathrm{~mm}$. wide. Fig. 218. BROWNTOP

Agrostis tenuis Sibth.

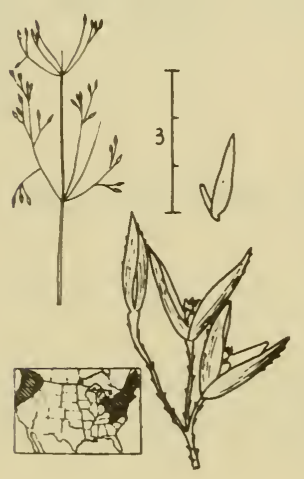

Figure $2 ! 8$

Perennial; plants $20-40 \mathrm{~cm}$. tall; rhizomes absent but short stolons sometimes present; leaf blades very narrow; ligules on sterile shoots about $1 \mathrm{~mm}$. long, on the culms up to $2 \mathrm{~mm}$. long; panicles usually $5-10 \mathrm{~cm}$. long, brownish, open and delicate, the spikelets all near the outer tips of the branches. Agrostis tenuis is cultivated as a lawn and pasture grass and is sometimes referred to as Rhode Island bent, Prince Edward Island bent, Colonial bent, New Zealand bent, or Astoria bent. The plants are occasionally found growing wild in regions where browntop is cultivated. Some forms possess lemmas which bear a delicate awn attached near the base. Introduced from Europe. June -July. 
35b. Ligules 3-7 mm. long; leaf blades $2-6 \mathrm{~mm}$. wide. Fig. 219 . REDTOP

Agrostis alba L.

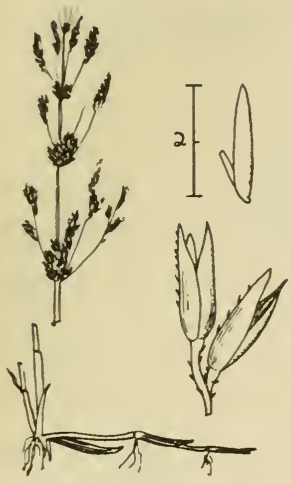

Perennial; culms up to $1-1.5 \mathrm{~m}$. tall; numerous creeping rhizomes present; panicle pyramidal, with rather dense whorls of branches, flowering to their bases. Redtop is one of our most important meadow grasses, and is also used in lawn seed mixtures. Roadsides, meadows, waste ground; very widely naturalized. June-August. Introduced from Europe.

Figure 219

36a. Panicle narrow, with the short branches bearing spikelets nearly

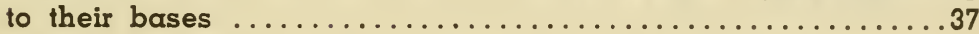

36b. Panicle open, the spreading branches bearing spikelets at their

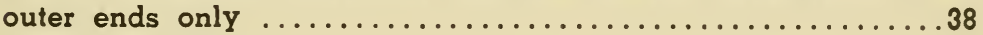

37a. Slender alpine plants; leaf blades $5 \mathrm{~cm}$. long or shorter, $1-2 \mathrm{~mm}$. wide: ligules $1-2 \mathrm{~mm}$. long; panicles usually less than $5 \mathrm{~mm}$. wide. Fig. 220.

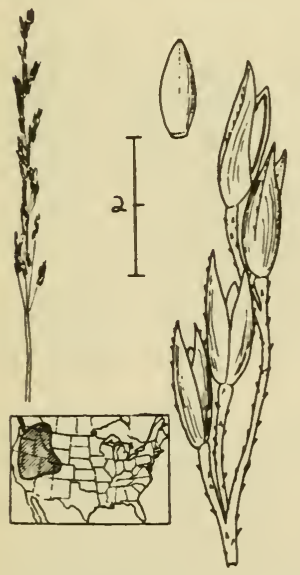

Figure 220

Agrostis variabilis Rydb.

Perennial; tufted; culms $10-20 \mathrm{~cm}$. tall; panicles small, 2-6 cm. long; spikelets about $2.5 \mathrm{~mm}$. long; lemmas about $1.5 \mathrm{~mm}$. long; palea very short. High altitudes in the mountains, usually above timberline along creeks and on slopes. Forage value good. JulyAugust.

Agrostis humilis Vasey. Similar but smaller, differing from the above chiefly in having a palea about $2 / 3$ as long as the lemma; plants $5-15 \mathrm{~cm}$. tall; panicles purple, slender, $1-3$ $\mathrm{cm}$. long. Excellent forage. Bogs and mountain meadows above timberline, Montana and Washington to Colorado and Nevada. JulyAugust. 
37b. Stouter plants of medium and low altitudes; longer leaf blades $8-10 \mathrm{~cm}$. long; ligules $3-6 \mathrm{~mm}$. long; panicles usually $\mathrm{l}-$ several cm. wide. Fig. 221.

SPIKE REDTOP

Agrostis exarata Trin.

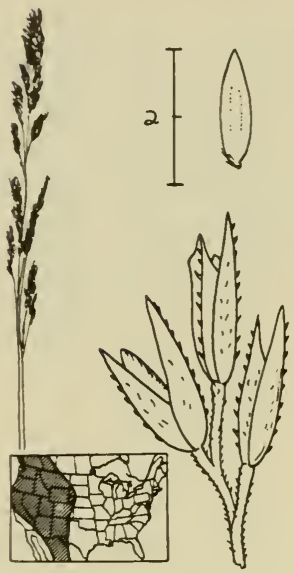

Perennial; tufted; culms $20-120 \mathrm{~cm}$. tall; panicles spikelike, either thin or thicker and somewhat lobed. Lemma sometimes awned. This is one of the most important western range grasses. It is palatable to both domestic livestock and wild grazing animals. Usually on moist ground, in meadows, along streams, and in open woodlands. JulyAugust.

Fेigure 221

38a. Panicles with long, slender main branches which branch again only on the outer half. Fig. 222.

TICKLEGRASS

Agrostis scabra Willd.

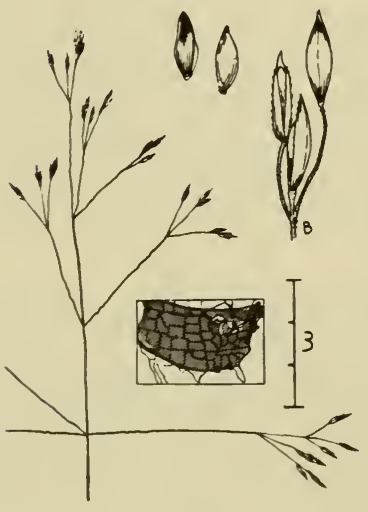

Figure 222

Perennial; culms slender, $20-80 \mathrm{~cm}$. tall; leaf blades threadlike, in dense tufts at the base of the culms; panicles delicate, readily breaking away from the plants and blown by the wind as tumbleweeds. Forage value fair. Ticklegrass is a very widespread species, on open ground or in partial shade, especially on moist soil. June-September.

Agrostis hyemalis (Walt.) B. S. P. is similar but has spikelets bunched at the tips of the branches. It blooms earlier, in May and early June. Atlantic coastal plain and lower Mississippi Valley. 
38b. Main panicle branches branching again below the middle. Fig. 223. Agrostis perennans (Walt.) Tuck.

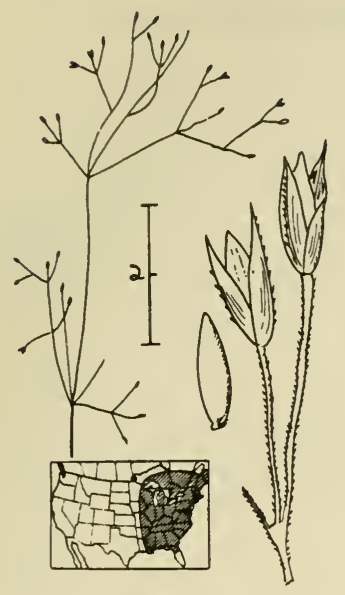

Perennial; tufted; culms $20-80 \mathrm{~cm}$. tall; panicles usually delicate and lace-like, especially in shade-grown plants. Lemmas rarely awned. Dry open fields and woodlands. July-October.

Agrostis oregonensis Vasey is similar, but larger and more vigorous. Marshes; Montana to British Columbia, southward to Wyoming and California.

Figure 223

39a. Glumes minute, less than $1 / 5$ as long as the lemma.......40

39b. Glumes half as long as the lemma or longer...........41

$40 \alpha$. Rachilla extending beyond the palea of the floret as a bristle; erect, broad-leaved forest grass. Fig. 224.

Brachyelytrum erectum (Schreb.) Beauv.

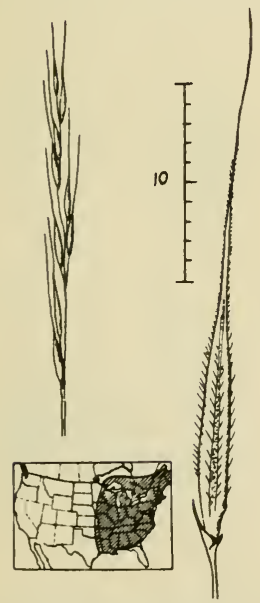

Figure 224

Perennial; tufted; culms $60-100 \mathrm{~cm}$. tall; leaf blades $10-15 \mathrm{~mm}$. wide, flat, rather light green; leaf sheaths and blades usually hairy; panicles slender, 5-15 cm. long, with erect branches; first glume nearly absent; second glume up to $2 \mathrm{~mm}$. long; floret cylindrical, firm, about $1 \mathrm{~cm}$. long, with an awn $1-2 \mathrm{~cm}$. long. Typical $B$. erectum is found mostly south of the glaciated areas of the eastern United States. The lemmas have stout, stiff hairs along the nerves and are otherwise glabrous. It grows in scattered stands in upland woods. June-July.

Var. septentrionale Babel grows mostly north of the glacial boundary, or southward in the mountains. The lemmas are sparsely and uniformly covered with minute appressed hairs or are nearly glabrous. Moist thickets and swampy woods. Also known from Japan. 
40b. Rachilla not prolonged; weak, sprawling weedy grass of disturbed soil, lawns, etc. Fig. 225.

NIMBLE WILL

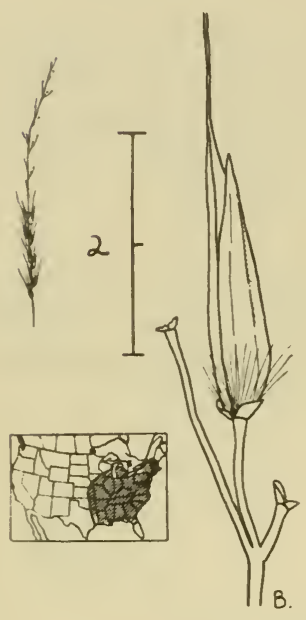

Figure 225
Muhlenbergia schreberi Gmel.

Perennial. The culms in early season are quite erect, but by flowering time they become much-branched and sprawl on the ground, the lower nodes often rooting. The erect portions of the culms are $10-30 \mathrm{~cm}$. long. Leaf blades usually $2-4 \mathrm{~mm}$. wide; foliage glabrous; panicles borne at the tips of the culms and from leaf axils, slender and weak, 5-15 cm. long. The glumes are vanishingly small, the first sometimes entirely lacking and the second only a few tenths of a millimeter long. Florets cylindrical, about $2 \mathrm{~mm}$. long, hairy on the callus; awn 2-5 mm. long, very slender. Nimble Will may become a weed in shaded lawns and shrubbery borders, but it does not seem very aggressive. It also is found growing in woods and thickets, roadsides and city streets, old fields, and meadows. August-October, rarely blooming in June or July.

4la. Lemma bearing an awn; nerves of lemma 3 or 5

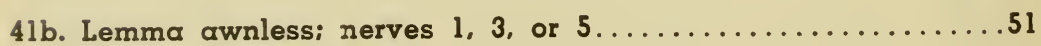

42a. Plants producing elongated rhizomes

42b. Plants lacking rhizomes (old tufts sometimes stooling out) . . .47

43a. Panicles slender, with short ascending branches; spikelets awned or awnless, on short pedicels.....................44 
43b. Panicles open, with spreading branches; tiny awnless spikelets on long slender pedicels. Fig. 226.

SCRATCHGRASS Muhlenbergia asperifolia (N. \& M.) Parodi.

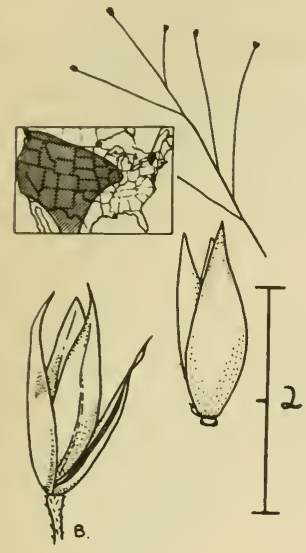

Perennial; bushy, $10-50 \mathrm{~cm}$. tall, with rhizomes; panicles open, dome-like, 5-15 $\mathrm{cm}$. long; plants pale green in color; leaf blades $2-5 \mathrm{~cm}$. long, $1-2 \mathrm{~mm}$. wide; ligules minute. The grains are often swollen up into spherical shape by the action of a fungus. Moist, often alkaline soil. June-September.

Muhlenbergia arenacea Buckl. is similar but has prominent ligules, $1-2 \mathrm{~mm}$. long. Texas to Colorado and Mexico.

Figure 226

44a. Leaf blades $3 \mathrm{~mm}$. wide or wider, more than $5 \mathrm{~cm}$. long, flat; lemmas awned or awnless.........................45

44b. Leaf blades $1-2 \mathrm{~mm}$. wide, less than $5 \mathrm{~cm}$. long, usually rolled; lemmas awnless. Fig. 227.

MAT MUHLY

Muhlenbergia richardsonis (Trin.) Rydb.

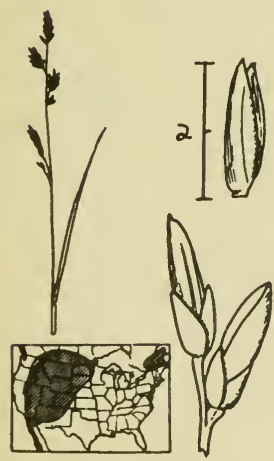

Perennial; much-branched, spreading by hard, thin rhizomes and forming mats, the erect portions of the culms $5-60 \mathrm{~cm}$. long; panicle slender, 2-10 cm. long. Mat muhly is a grass of open, often wet or alkaline soil. While rather tough, it furnishes fairly good livestock feed. The densely matted plants furnish considerable erosion protection to the soil. July-September. Also known as $M$. squarrosa (Trin.) Rydb.

Figure 227

45a. Glumes not longer than the lemma, less than $3.5 \mathrm{~mm}$. long....46 
45b. Glumes much longer than the lemma, tapering to awn tips. Fig. 228.

Muhlenbergia glomerata (Willd.) Trin.

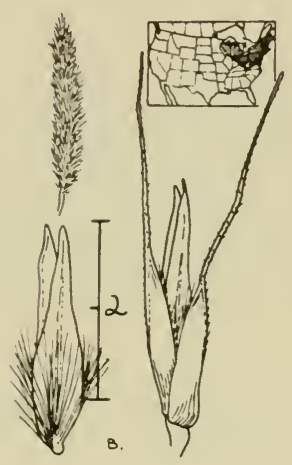

Figure 228

Perennial; culms in tufts, $30-90 \mathrm{~cm}$. tall, with slender creeping rhizomes; panicles dense, cylindrical, and somewhat lobed, often purplish in color, 3-10 cm. long; anthers 1$1.5 \mathrm{~mm}$. long. Moist or rocky ground. July -October.

Muhlenbergia racemosa (Michx.) B.S.P. is similar, but has small anthers less than $1 \mathrm{~mm}$. long. Prairies, wet or rocky ground, Manitoba and Indiana to Alberta and Washington.

46a. Culms much-branched, with numerous small panicles in the axils of the leaf sheaths; stems smooth and shining. Fig. 229.

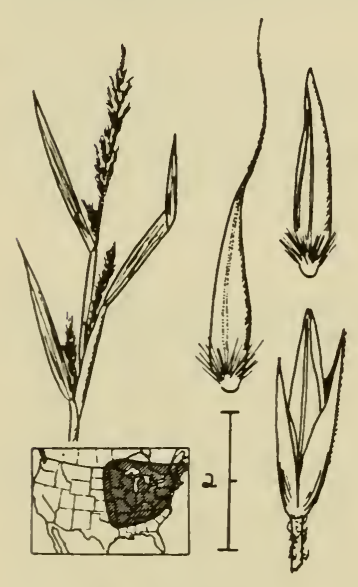

Figure 229

Muhlenbergia frondosa (Poir.) Fern.

Perennial; rhizomes present; culms becoming elongated, $40-100 \mathrm{~cm}$. or more long, the plants becoming bushy and much-branched, frequently scrambling through bushes or other vegetation or sprawling; panicles at the tips of the culms and protruding from nearly every leaf sheath, up to $10 \mathrm{~cm}$. long, rather dense; leaf blades flat, scabrous, $3-7 \mathrm{~mm}$. wide; glumes 2-4 $\mathrm{mm}$. long, tapering gradually from base to an awned tip; lemmas $2-3$ $\mathrm{mm}$. long, awnless or awned. This is a very common species in thickets and woods and on roadsides and stream banks. AugustOctober.

Muhlenbergia sobolifera (Muhl.) Trin. is somewhat similar, but the glumes curve abruptly to awn tips from a point above the middle. The culms are erect and sparingly branched. Lemmas awnless. Dry woods. New Hampshire to Virginia, westward to Nebraska and Texas. July-October. 
46b. Culms not much branched; panicles all at the tips of long protruding branches or the main culms; stems dull, roughened with minute hairs, especially below the joints. Fig. 230.

Muhlenbergia sylvatica Torr.

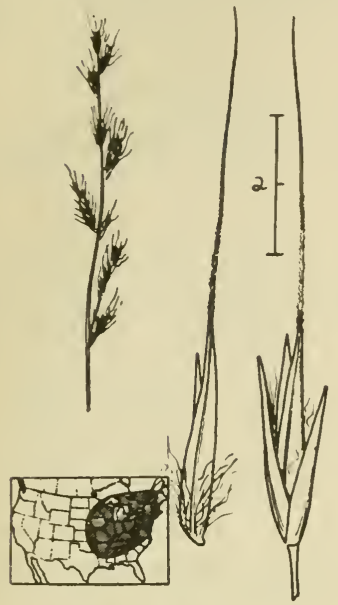

Figure 230

Perennial; culms $40-100 \mathrm{~cm}$. tall; rhizomes present; plants often bushy; leaf blades flat, soft, 2-8 $\mathrm{mm}$. wide; panicles narrow, arching, with thin, erect branches; some of the spikelets on pedicels as long as the glumes; glumes tapering to awn points, 2-3 $\mathrm{mm}$. long; lemma slightly longer, hairy on the callus and lower portion, with an awn 5-10 mm. long. The culms feel file-like when scratched with the finger nail, especially below the nodes. Forms with short awns or none are known. Woods, meadows, thickets, and roadsides. August-September.

Muhlenbergia mexicana (L.) Trin. is similar but has denser, usually lobed panicles, most of the spikelets being nearly sessile on the branches; lemmas awnless; leaf blades $2-4 \mathrm{~mm}$. wide. Rocky shores, moist woods, swamps. Throughout most of the United States except Texas and the southeastern states.

$47 a$. Second glume not toothed................... 48

47b. Second glume 3-toothed near the tip. Fig. 231.

Muhlenbergia montana (Nutt.) Hitch.

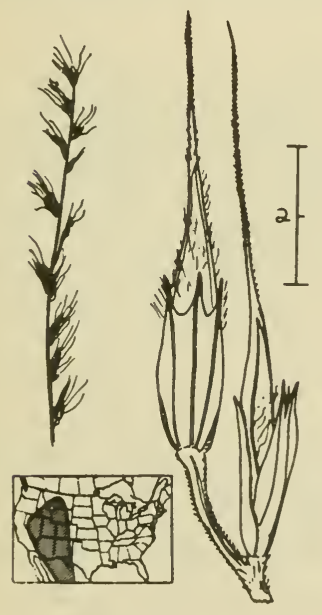

Perennial; culms in large, dense tufts, 30 $-60 \mathrm{~cm}$. tall; panicles slender, with ascending branches. The 3-toothed second glume is the best identifying mark of this species. The old sheaths at the base of the plants become flat and stiff, like thin wooden splints. This species yields fairly palatable forage, especially when the herbage is young. Ponderosa pine, spruce, and fir forests, $2300-3300 \mathrm{~m}$. elevation. July-October. 
48a. Panicle very narrow, the short branches bearing spikelets nearly

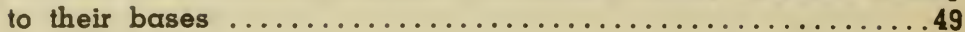

48b. Panicle broad, open, the spikelets borne near the tips of the

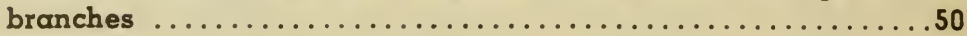

49a. Awn shorter than the lemma or lacking. Fig. 232.

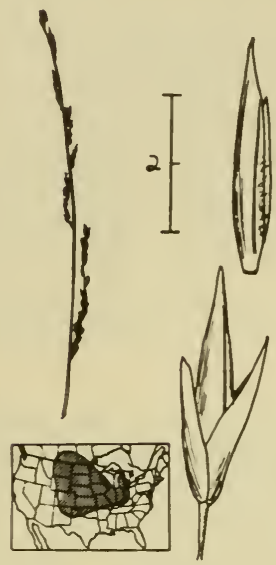

Muhlenbergia cuspidata (Torr.) Rydb.

Figure 232

Perennial; tufted; culms slender and wiry, $20-40 \mathrm{~cm}$. tall; ligules minute; panicles very slender. Dry hills and prairies. July-September.

Muhlenbergia wrightii Vasey (SPIKE MUHLY) is similar but has a denser panicle, somewhat like timothy. The ligule is l-2 $\mathrm{mm}$. long. It is an important grazing grass on open or bushy ranges, ponderosa pine forests, from southern Colorado and Utah southward.

49b. Awn l-several times as long as the lemma. Fig. 233. BULLGRASS

Muhlenbergia emersleyi Vasey

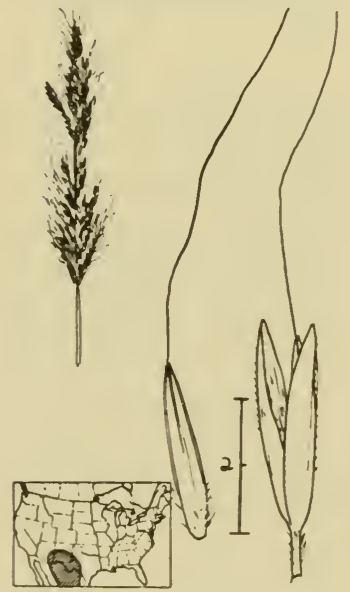

Figure 233

Perennial; in large tufts; culms tall and stout, 50-100 cm. tall; sheaths glabrous, flattened and keeled; lower leaf blades up to $50 \mathrm{~cm}$. long; blades flat or folded, rough, l-4 $\mathrm{mm}$. wide; ligules thin, $1-2 \mathrm{~cm}$. long; panicles long and narrow, $20-40 \mathrm{~cm}$. long, with ascending, overlapping branches; spikelets often somewhat purplish; glumes scabrous; lemmas hairy on the lower half, awnless or with an awn up to $25 \mathrm{~mm}$. long attached below the apex. Some panicles may have both awned and awnless spikelets. Canyons and rocky woods; said to be a good soil binder. September-October. 
50a. Plants forming sprawling, much-branched bushes from knotty crowns. Fig. 234.

BUSH MUHLY

Muhlenbergia porteri Scribn.

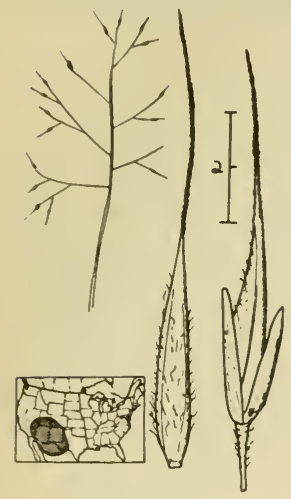

Perennial; the much-branched plants will form bushy growth a meter in diameter and height if ungrazed. Because of the very high palatability of this species for grazing livestock, it is rarely seen except in the hearts of spiny bushes. The plants are semi-evergreen, the old culm bases producing new shoots in the succeeding year. Dry plains and deserts. July-September.

Figure 234

50b. Stems erect, usually unbranched. Fig. 235.

RINGGRASS

Muhlenbergia torreyi (Kunth) Hitch.

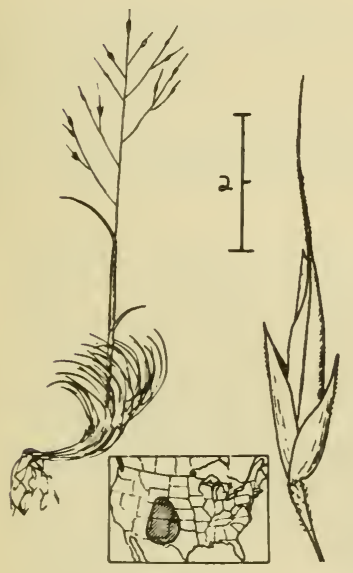

Perennial; plants forming circular or ringshaped tufts, with numerous short, curly leaves, mostly clustered at the base of the plant. Ringgrass is a rather poor forage grass. Its presence usually indicates that better species have been killed out. Open plains, 1300-3300 m. elevation. JulyÅugust.

Figure 235

5la. Floret bearing a tuft of hairs on the callus; panicles large and open. Fig. 236. .genus CALAMO. VILFA, see Fig. 216.

$51 \mathrm{~b}$. Floret without conspicuous hairs on the callus (sometimes hairy on the nerves) .........52

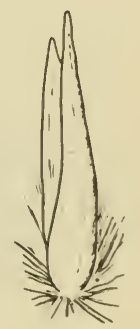

Figure 236 
$52 \alpha$. Nerves of the lemma without silky hairs.....53

$52 \mathrm{~b}$. Lemma 3-nerved, the nerves densely covered with short silky hairs. Fig. 237.

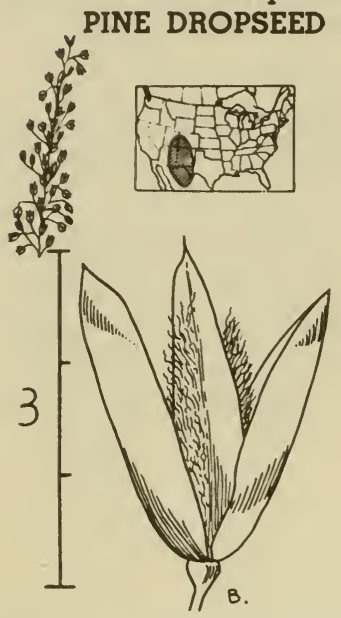

Blepharoneuron tricholepis (Torr.) Nash

Perennial; tufted; culms slender, almost leafless, $20-60 \mathrm{~cm}$. tall. The leaf blades are crowded in a basal tuft about a third as long as the culms. The panicles are loosely cylindrical, somewhat grayish in color. This species is a good forage grass, especially in early season. Open parks and thin woods, ponderosa pine, spruce, and fir forests. July-October.

Figure 237

53a. Lemmas with 3-5 nerves, awned or awnless: grain remaining inclosed by the lemma and palea; ovary wall not separable from the seed............................ go back to 42

$53 \mathrm{~b}$. Lemmas with one nerve, awnless; grain falling free of the lemma and palea at maturity; ovary wall when wet usually swelling into a jelly-like material which can be peeled from the seed...54

$54 a$. Glumes plainly unequal in length..................55

$54 \mathrm{~b}$. Glumes equal in length, nearly as long as the floret; plants annual, in small tufts with very shallow roots. Fig. 238.

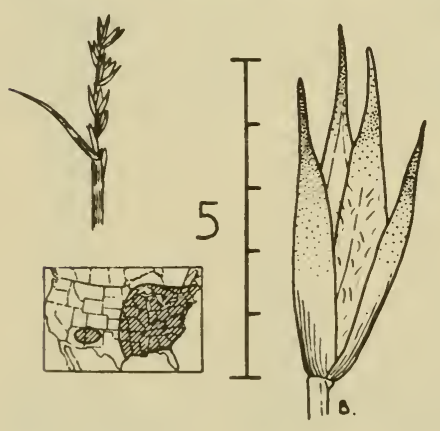

Figure 238

Sporobolus vaginaeflorus (Torr.) Wood

Annual; culms thin, wiry, 10-40 $\mathrm{cm}$. tall, in small tufts; panicles mostly concealed within the upper leaf sheaths, or only the tips protruding. The lemmas are usually blackish-spotted, and the palea is often longer than the lemma. Both lemma and palea are covered sparsely with appressed hairs. Dry sterile open ground. August-October.

Sporobolus neglectus Nash is similar, but has shorter, plumper spikelets with glabrous lemmas. Northeastern and midwestern United States. 
55a. Spikelets $4-7 \mathrm{~mm}$. long.................. 56

55b. Spikelets $1-2.5 \mathrm{~mm}$. long.................... 57

56a. Panicle open, with spreading branches. Fig. 239.

PRAIRIE DROPSEED

Sporobolus heterolepis Gray

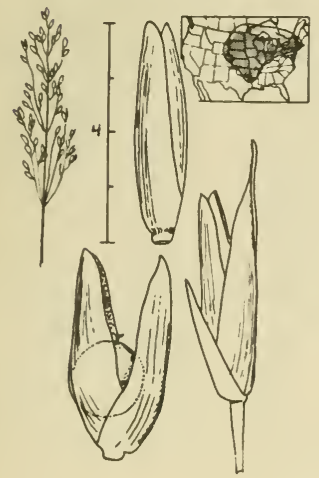

Perennial; plants forming large tufts; culms $30-70 \mathrm{~cm}$. tall; panicles narrowly ovoid. The spikelets become much distended by the ripening grain, which is spherical and yellowish at maturity and about $2 \mathrm{~mm}$. in diameter. The palea readily splits down the middle as the grain develops. Prairies. July-October.

Figure 239

56b. Panicle spikelike, mostly hidden in the uppermost sheath. Fig. 240. Sporobolus asper (Michx.) Kunth

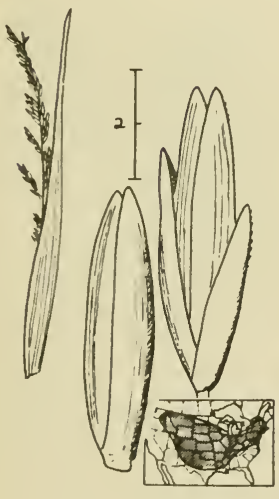

Figure 240

Perennial; tufted; culms $60-120 \mathrm{~cm}$. tall; leaf blades flat or rolled, $1-4 \mathrm{~mm}$. wide, tapering to a slender tip; panicles whitish or somewhat purplish in color, $5-15 \mathrm{~cm}$. long. Open ground and prairies. AugustSeptember.

Sporobolus macer (Trin.) Hitch. is very similar, but has scaly rhizomes. Pine forests; Mississippi to Oklahoma and eastern Texas.

Sporobolus clandestinus (Biehler) Hitch. is similar, but has hairy florets; lemma and palea slender-pointed, the palea longer than the lemma. Dry sandy lands; Connecticut to Wisconsin, Kansas, Texas and Florida.

$57 a$. Sheaths glabrous or nearly so at the summit............58 
57b. Sheaths bearing conspicuous tufts of white hairs at their summits. Fig. 241.

SAND DROPSEED

Sporobolus cryptandrus (Torr.) Gray

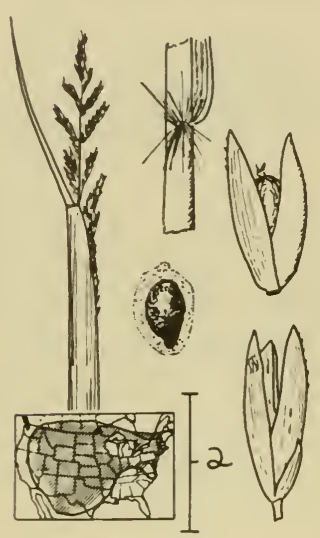

Figure 241

Perennial; tufted, the erect or spreading culms 30-100 cm. long; panicles borne at the apex of the culms and in the axils of the upper sheaths. The tufts of straight silky hairs on the flanges at the summits of the sheaths are prominent. Sand dropseed is a rather important forage species on coarse or sandy soil in the West. It produces an abundance of fine, long-lived seed, and will recover rapidly from the effects of overgrazing. July-October.

Sporobolus giganteus Nash (GIANT DROPSEED) resembles the above, but may be distinguished by its large size, from l-2 m. tall, and slightly larger spikelets, 2.5-3 $\mathrm{mm}$. long. Sand plains, western Oklahoma and Texas to Colorado and Arizona.

58a. Panicle not more than twice as long as wide; leaf blades usually rolled. Fig. 242.

ALKALI SACATON

Sporobolus airoides Torr.

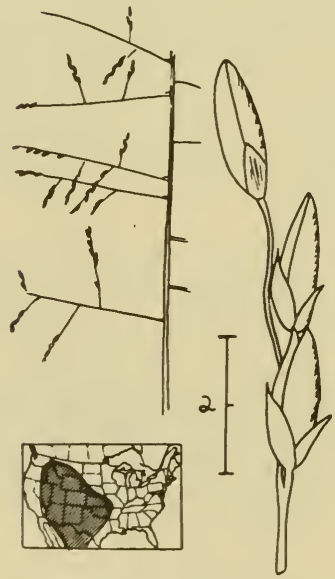

Perennial; culms tough and rigid, in large clumps; plants $50-100 \mathrm{~cm}$. tall. The large, open, dome-shaped panicles make up half or more of the height of the plant. The paleas of the florets often split as the grain develops. The plants can grow on very salty or alkaline soil. Although the herbage is tough, it is taken greedily by livestock, probably because of the large amount of salt in the tissues. Frequently, minute salt crystals can be seen glistening on the leaf surfaces with a hand lens. Plains and alkali flats, often on heavy clay soils. June-September.

Figure 242 
58b. Panicle three or more times longer than wide; leat blades usually flat. Fig. 243.

SACATON

Sporobolus wrightii Munro

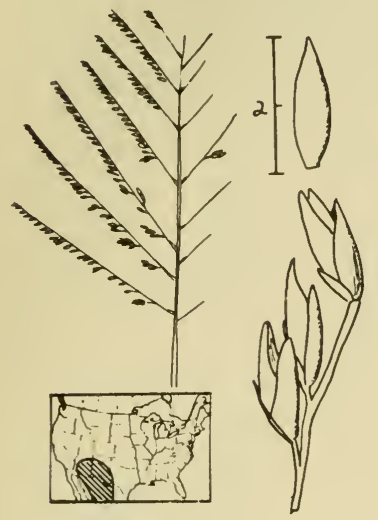

Perennial; culms in large tufts, stout and tough, $1-2.5 \mathrm{~m}$. tall; panicles up to $60 \mathrm{~cm}$. long, the branches bearing spikelets nearly to their bases. The plants furnish good grazing when young, and are sometimes cut for hay. River flats, especially where overflows occur. July - September.

Figure 243

\section{TRIBE VI. ZOYSIEAE}

1a. Spikelets inclosed in spiny burs, the spines hooked at the tips. Fig. 244.

COCKLEBUR GRASS

Tragus berteronianus Schult.

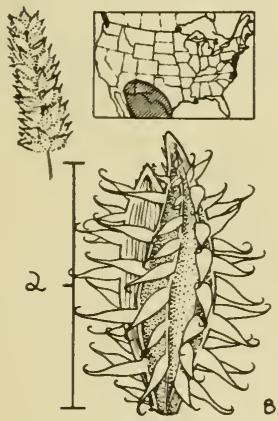

Figure 244

Annual; culms $10-40 \mathrm{~cm}$. long, spreading. The burs are borne along a slender raceme, from which they fall readily. Each bur consists of a group of $2-5$ spikelets, but the second glumes of the two lower spikelets are covered with hooked prickles and conceal the remainder. The plants occur on dry open ground in the Southwest and also at scattered points on the east coast where wool is processed. The burs are readily transported by the wool of sheep. Probably introduced from the old world; extending through the warmer portions of both hemispheres. August-October.

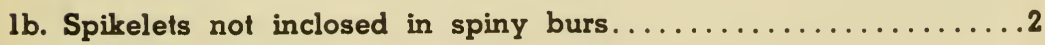

$2 \alpha$. Spikelets falling in groups of 3 , all without stalks..........

2b. Spikelets falling in pairs, each spikelet on a short stalk........ genus Lycurus. Fig. 191. 
3a. Plants spreading by slender creeping stolons; culms $10-30 \mathrm{~cm}$. tall. Fig. 245.

CURLY MESQUITE GRASS.

Hilaria belangeri (Steud.) Nash

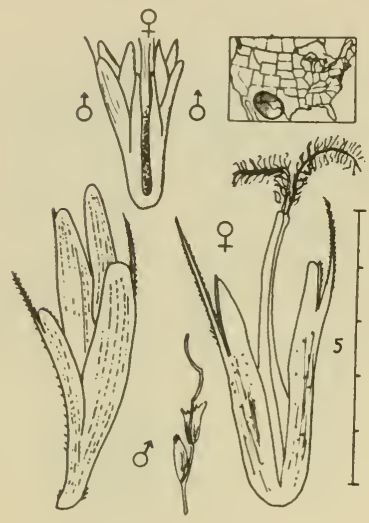

Figure 245

Perennial; forming extensive flat mats, the stolons rooting at the nodes. Dry plains, foothills, and brushy land, 650$1800 \mathrm{~m}$. elevation; often on heavy clay soils. Blooming occurs sporadically durin the growing season.

Curly mesquite is an important range grass in the Southwest. Because of its stolons, it stands up well under heavy grazing. Where it occurs with buffalo grass, it is regarded as inferior to buffalo, being less productive and not curing out as well. The plants greatly resemble those of buffalo grass (Buchloe dactyloides, see Fig. 247), but may be distinguished by the spikelets and by the following features: 1. Color. Curly mesquite is light green when fresh, whitish when dry. Buffalo grass is grayish or olive green when fresh; tan, brownish or purplish when dry. 2. Stolons. The stolons of curly mesquite are round in cross section, very slender, and have tufts of hair at the joints. Those of buffalo grass are oval in cross section, stouter, and smooth at the joints.

$3 b$. Plants erect, without stolons; rhizomes present. Fig. 246.

GALLETA GRASS

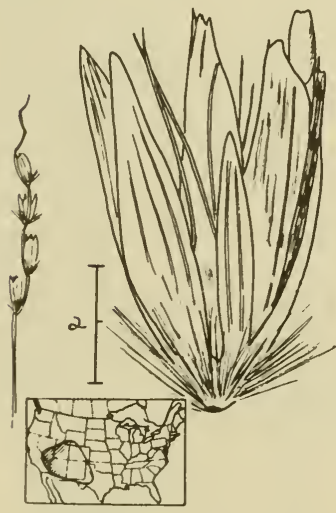

Figure 246

Hilaria jamesii (Torr.) Benth.

Perennial; culms tough, erect, $30-50$ $\mathrm{cm}$. tall, from stout, scaly rhizomes. The racemes of clustered spikelets are whitish. After the groups of spikelets fall, the rachis remains behind as a thin, zigzag straw. Galleta (pronounced gieyetta) is an important forage grass on dry plains and deserts in the Southwest. It is fairly palatable to horses and cattle when fresh and green, but is scarcely eaten when dry. June-August.

Hilaria mutica Benth. (TOBOSA GRASS) is very similar, but the first glume on each lateral spikelet is fanshaped. Heavy clay soils, especially on river bottoms where flooding occurs. Western Texas to Arizona.

Hilaria rigida (Thurb.) Benth. (BIG GALLETA) is larger, and has the culms covered with a dense white felt of hairs. Southwestern deseris. 


\section{TRIBE VII. CHLORIDEAE}

la. Spikelets not inclosed in beads; flowers perfect...........

lb. Pistillate spikelets inclosed in yellowish, bony, bead-like structures; plants unisexual; staminate spikelets borne in $1-3$ spikes; plants producing extensive creeping stolons. Fig. 247.

BUFFALO GRASS

Buchloe dactyloides Engelm.

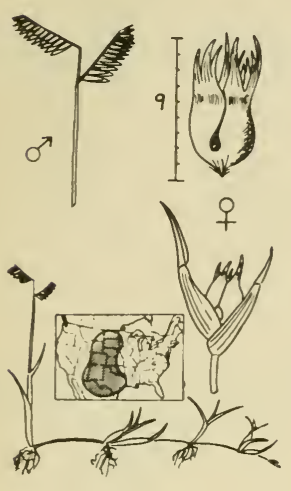

Figure 247

Perennial; spreading widely by stolons; pistillate spikelets inclosed in bead-like bodies with a short green crown on top; staminate spikelets in short, flag-like spikes. The two sexes are borne on separate plants. The diminutive plants are rarely more than 20 $\mathrm{cm}$. tall. Leaves short, curly, grayish-green. Despite its small size, this species is one of the most important forage grasses of the Great Plains, furnishing excellent forage year long. It resembles closely Hilaria belangeri (see Fig. 245). For ways of distinguishing the two when not fruiting, see the discussion under that species. Buffalo grass frequently grows with blue grama grass (see Bouteloua gracilis, Fig. 271) and resembles it, except that the grama grass lacks stolons. Blooming time mostly in the spring, but also later in the season.

2a. Inflorescences consisting of a few spikelets hidden in the sheaths of stiff, sharp-pointed leaves; annual, making circular or domeshaped patches from one root. Fig. 248.

FALSE BUFFALO GRASS

Munroa squarrosa (Nutt.) Torr.

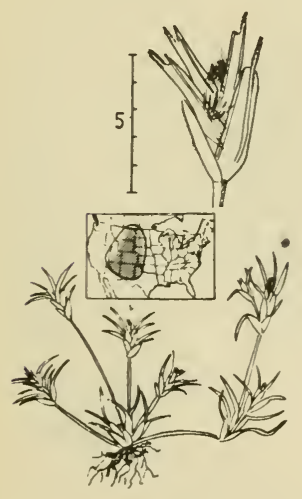

Leaves of Munroa are stiff, harsh, and somewhat curled backwards. The spikelets are borne in two's or three's on short, one-sided spikes. The small vegetative leaves and glumes are similar and hard to distinguish. The plants grow on overgrazed or disturbed soil in blow-outs, around prairie dog towns, corrals, etc. Forage value very low. JuneAugust.

Figure 248 
2b. Inflorescence not hidden by the leaves; plants annual or perennial,

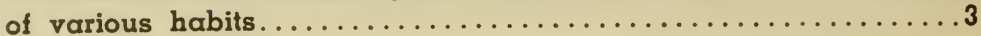

3a. Spikelets with 2 or more fertile florets................

3b. Spikelets with 1 fertile floret, often variously shaped rudimentary ones above the perfect one........................

4a. Spikes numerous, in a panicle.....................

4b. Spikes few (usually less than 6), all arising from one central point .7

5a. Spikelets $5-10 \mathrm{~mm}$. long; lemmas awned or awnless.......6

5b. Spikelets 1-2 mm. long; lemmas awnless; Fig. 249. RED SPRANGLETOP Leptochloa filiformis (Lam.) Beauv.

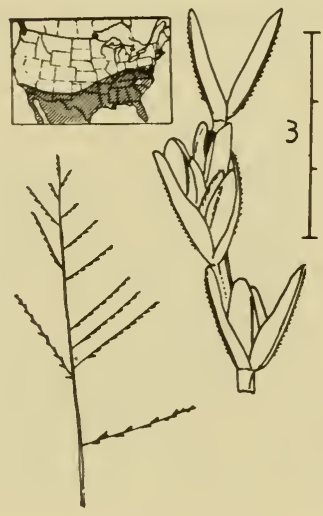

Annual; plants tufted, $20-70 \mathrm{~cm}$. tall. The reddish or purple panicles may be half the height of the plants, with numerous thread-like spikes bearing the very tiny spikelets. Red sprangletop is a rather rampant weed, frequent on bottomlands, in fields, and in gardens. August-September.

Figure 249 
6a. Lemmas notched at the blunt apex, awnless, glabrous or nearly 80 . Fig. 250.

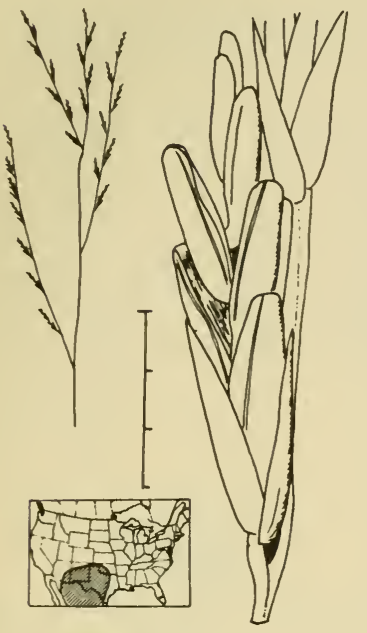

Figure 250

Perennial; tufted; culms $50-100 \mathrm{~cm}$. long, tough, erect; leaf sheaths smooth; blades flat or somewhat rolled or folded, up to $10 \mathrm{~mm}$. wide; panicles up to 15 $\mathrm{cm}$. long, the spreading spikes $3-12$ $\mathrm{cm}$. long; spikelets 5-10 $\mathrm{mm}$. long, usually with 5-8 or occasionally fewer florets; lemmas oblong, blunt, the tip notched, the midnerve sometimes protruding. The plants sometimes bear cleistogamous inflorescences hidden in the sheaths. This species has some value as a forage grass in the Southwest. Sandy or rocky open ground. March-September.

6b. Lemmas tapering to a sharp point, awned, hairy on the nerves. Fig. 251.

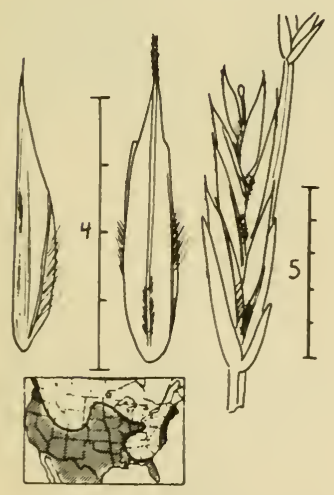

Figure 251

Leptochloa fascicularis (Lam.) Gray

Annual; tufted; culms $30-100 \mathrm{~cm}$. long, erect or horizontally spreading; plants becoming much-branched; leaf blades flat or somewhat rolled; panicles rather stiff, usually partly hidden in the leaf sheaths, $10-20 \mathrm{~cm}$. long, the individual spikes up to $10 \mathrm{~cm}$. long; spikelets $7-12 \mathrm{~mm}$. long, with 6-12 florets; awns ranging from very short to 4-5 $\mathrm{mm}$. long. Moist or alkaline soil, salt marshes, open ground. JulySeptember. This is an unusually widelyranging grass, extending southward through the American tropics to Argentina. It is sometimes placed in the genus Diplachne. 
7a. Rachis of each spike extending beyond the spikelets as a naked point: second glume awned. Fig. 252.

Dactyloctenium aegyptium (L.) Richt.

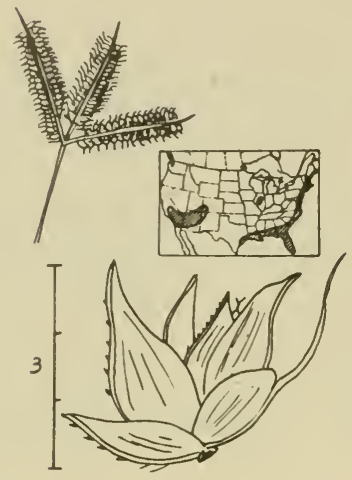

Figure 252

Annual; tufted; culms upright or spreading out and forming mats, rooting at the lower nodes. The seeds (ovary wall is lost) are brownish, about the size of a pinhead, and oddly sculptured. Weed on cultivated ground. This species was apparently once planted by the Indians along the lower Colorado River for grain. Introduced from Europe. Summer, or almost yearlong in the far South.

7b. Rachis of the spikes not extended beyond the spikelets; glumes without awns. Fig. 253. GOOSEGRASS

Eleusine indica (L.) Gaertn.

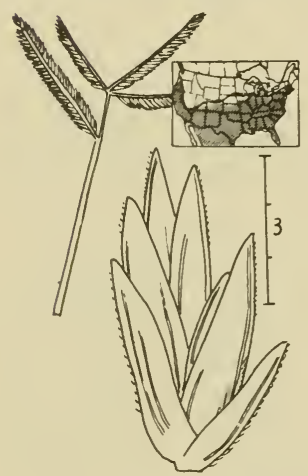

Annual; culms up to $50 \mathrm{~cm}$. long, spreading horizontally or standing erect; plants often making flat mats. Goosegrass is a very common weed of fields, gardens, paths, and disturbed ground generally in the southeastern United States. Introduced from the warmer sections of the world. March-October.

Figure 253

$8 a$. Spikelets with a single floret, without sterile or rudimentary ones

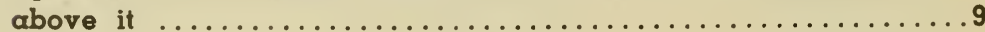

8b. Spikelets with 1 or more modified sterile florets above the perfect

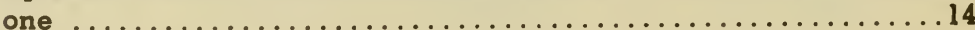


9a. Plants lacking stolons; rachilla not prolonged beyond the floret. . 10

9b. Plants producing extensive creeping stolons; rachilla prolonged beyond the floret as a smooth bristle. Fig. 254.

BERMUDA GRASS

Cynodon dactylon (L.) Pers.

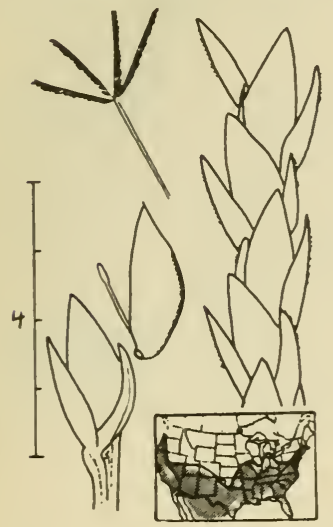

Figure 254

Perennial; producing both stolons and rhizomes and forming a fine green turf; erect portions of culms $10-40 \mathrm{~cm}$. tall, bearing about 4-5 slender spikes at the apex. Bermuda grass is one of the principal lawn grasses in the South and furnishes much pasturage as well. It is very persistent when once established and may become a serious weed pest on agricultural lands. This species is apparently native to the tropics of the Old World, but has become widely dispersed in warmer parts of the world. Blooming period extends through the warm season, and may be yearlong in the subtropics.

10a. Spikelets several times longer than wide, ovate in outline.....11

10b. Spikelets nearly circular in outline, falling entire. Fig. 255. SLOUGH GRASS

Beckmannia syzigachne (Steud.) Fern.

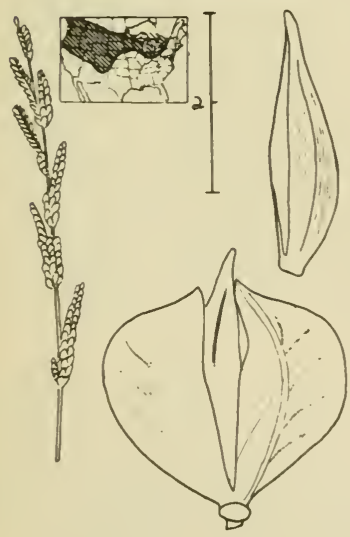

Annual; tufted; plants up to $100 \mathrm{~cm}$. tall. The slender, wand-like panicles of spikes produce large quantities of wrinkled, circular spikelets which shatter from the plants at a touch. Plants rather tender and succulent; forage value good. Wet meadows; shores of ditches and lakes, mostly in the western states. The plants are sometimes cut for hay. July-August. 
11a. Plants with rhizomes; spikelets disarticulating below the glumes,

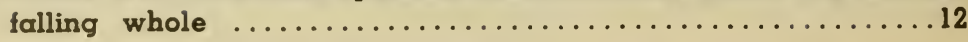

11b. Plants tufted, lacking rhizomes; spikelets disarticulating above the glumes, the floret dropping. Fig. 256.

TUMBLEGRASS

Schedonnardus paniculatus (Nutt.) Trel.

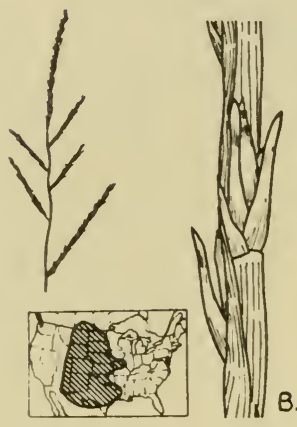

Perennial; tufted; plants $20-40 \mathrm{~cm}$. tall, with short, crowded basal leaves. Most of the height of the plant is made up of the skeleton-like panicle of very slender spikes. The main axis of the inflorescence is somewhat spiral. The whole panicle breaks from the plant when ripe and rolls with the wind, thereby distributing the seed. This is a grass of poor, dry soil, especially on overgrazed or disturbed areas. Forage value very low. June-August.

Figure 256

12a. Leaf blades flat when fresh, $4-25 \mathrm{~mm}$. wide...........

12b. Leaf blades rolled, $2 \mathrm{~mm}$. or less wide. Fig. 257. SALT-MARSH GRASS

Spartina patens (Ait.) Muhl.

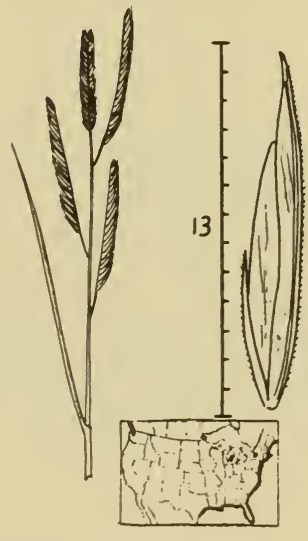

Figure 257
Perennial; spreading by slender, scaly rhizomes, forming large colonies in coastal salt marshes along the Atlantic and Gulf coasts. Culms up to $1 \mathrm{~m}$. tall, usually shorter. This grass is tough and harsh, but is frequently harvested for hay, which is used as packing material. The plants are valuable as land-builders along the coast, trapping and holding the tidal mud. July-September.

Spartina gracilis Trin. (ALKALI CORDGRASS) is similar, but is found on alkali or salty flats in the interior of the United States, from the Dakotas to Kansas, westward to Washington and California. 
13a. Leat margins rough to the touch; plants widespread. Fig. 258. SLOUGH GRASS Spartina pectinata Link

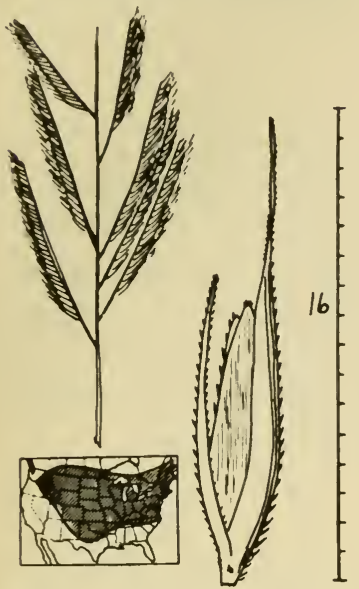

Figure 258

Perennial; spreading by tough, scaly rhizomes which are up to $1 \mathrm{~cm}$. thick; culms tall, $1-2 \mathrm{~m}$. in height. The whole plant is coarse and tough, with sawedged leaves. Slough grass was formerly one of the dominant grasses of the tall grass prairie region of the north central United States. Now it survives largely along roadsides, in ditches, and on wet ground. July-September.

Spartina cynosuroides (L.) Roth is taller, has numerous spikes; second glume without an awn. Salt marshes, Atlantic and Gulf coasts.

13b. Leaf margins smooth; plants of Atlantic coastal salt-marshes. Fig. 259.

Spartina alterniflora Loisel

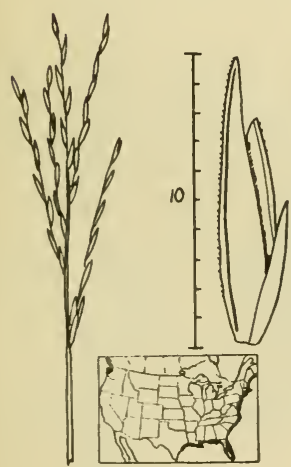

Figure 259

Perennial; spreading by rhizomes; culms $.5-2.5 \mathrm{~m}$. tall, thick and spongy; leaf blades flat, 5-15 $\mathrm{mm}$. wide, tapering to a fine point; panicles narrow, the spikes slender and erect, 5-15 cm. long; spikelets about $1 \mathrm{~cm}$. long, the floret smooth or slightly hairy. Coastal salt marshes, often growing in shallow water. Introduced along the coast of southwestern Washington. July-October.

Nearly a century ago, this species was introduced into southern England. There it formed a highly successful natural hybrid with a European species. This hybrid, Spartina townsendii, is now building extensive areas of dry land from former tidal mud flats there.

14a. Second glume without a protruding bristle on the back; inflores-

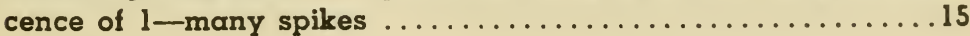


14b. Second glume bearing a protruding bristle on the middle of the keel; inflorescence a single curved spike. Fig. 260.

TOOTHACHE GRASS Ctenium aromaticum (Walt.) Wood

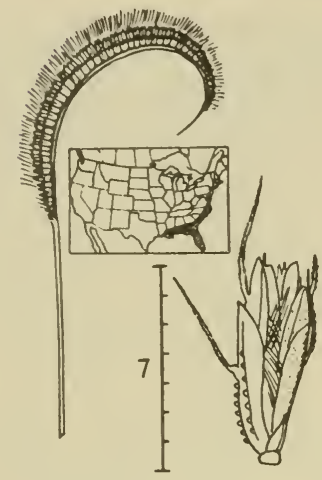

Perennial; tufted; plants $1-1.5 \mathrm{~m}$. tall. The bases of the plants are surrounded by the coarse, fibrous remains of the old sheaths. Toothache grass is a plant of wet pine woods on the sandy coastal plain. The fresh roots are said to have a spicy smell. The plants furnish some forage for cattle in the South. May-July.

Figure 260

15a. Fertile lemma with a single long awn or with 3 short awns, or awnless

15b. Fertile lemma bearing 3 long awns, at least twice as long as the body of the lemma. Fig. 261.

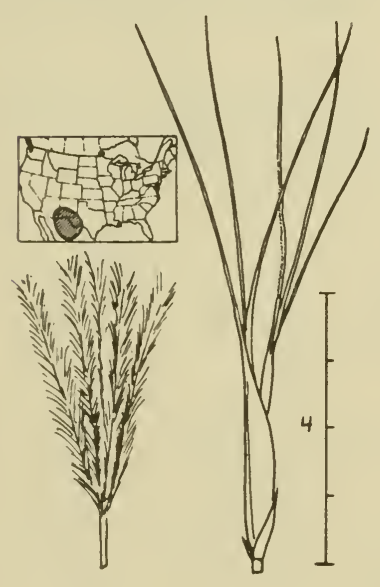

Figure 261

Trichloris crinita (Lag.) Parodi

Perennial; tufted; plants $40-100 \mathrm{~cm}$. tall; leaf blades $2-4 \mathrm{~mm}$. wide. The silvery panicle of spikes is vase-shaped, $5-15 \mathrm{~cm}$. long, feathery because of the numerous long awns. Individual spikes are $5-10 \mathrm{~cm}$. long. Spikelets disarticulating above the glumes; second floret rudimentary, reduced to awns; lemmas 3-nerved, all of the nerves extending into the awns, which are about $1 \mathrm{~cm}$. long. The plants are sometimes cultivated for ornament. Fields and rocky open ground. Autumn. Formerly known as Trichloris mendocina or T. blanchardiana.

16a. Spikes borne in one to several whorls, with two to many spikes in

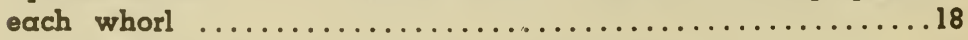

16b. Spikes borne singly at each joint of the rachis........... 
17a. Spikes very long and slender (1م-20 cm. long), the widely-spaced spikelets parallel to the rachis; spikes numerous, forming an open, dome-shaped panicle. Fig. 262.

Gymnopogon ambiguus (Michx.) B. S. P.

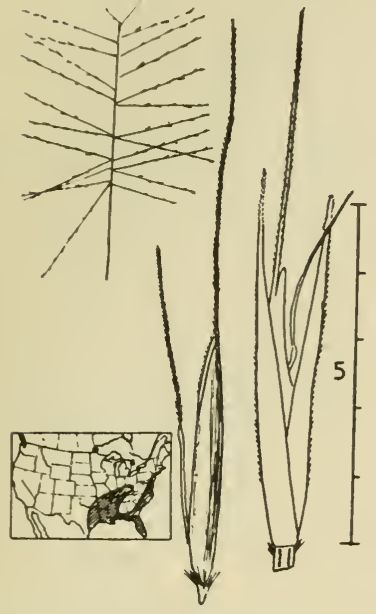

Perennial; tufted or with short rhizomes; culms $30-60 \mathrm{~cm}$. tall, stiff and erect, with overlapping sheaths and short, broad, spreading leaf blades. The slender spikes may reach $15-20 \mathrm{~cm}$. in length, and the whole panicle may be half the total height of the plant. Pine woods, mostly on the Atlantic and Gulf coastal plains. September-November, also in the spring.

Figure 262

17b. Spikes thicker, less than $5 \mathrm{~cm}$. long, the closely overlapping spikelets placed at an angle to the rachis; spikes 1 -many.......21

18a. Lemmas light colored, awned..................... 19

18b. Lemmas dark brown, nearly awnless; spikelets $2 \mathrm{~mm}$. long. Fig. 263.

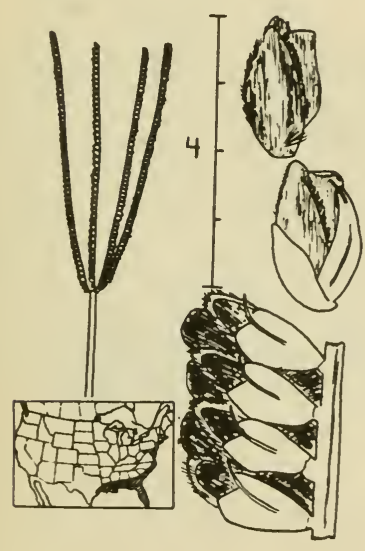

Chloris petraea Swartz

Perennial; tufted or with short stolons; plants up to $100 \mathrm{~cm}$. tall; spikes $4-10$ $\mathrm{cm}$. long; lemmas chocolate brown; leaf sheaths and culms strongly keeled; leaf blades pale in color and with rounded tips. This species grows in the pine woods of the southern Atlantic and Gulf coastal plains. August-May. 
19a. Lemmas without tufts of white hairs near the apex........20

19b. Lemmas bearing tufts of long, whitish hairs on the edges near the apex. Fig. 264.

FEATHER FINGERGRASS

Chloris virgata Swartz

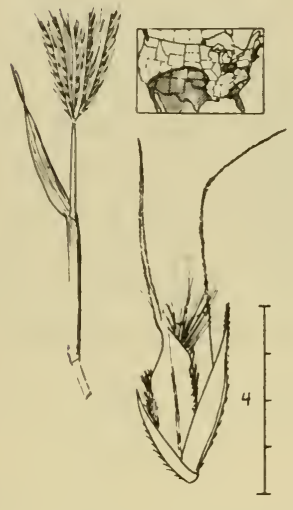

Figure 264

Annual; tufted; culms erect or spreading, $40-100 \mathrm{~cm}$. tall; some of the sheaths swollen; leaf blades $2-6 \mathrm{~mm}$. wide; spikes $2-8 \mathrm{~cm}$. long. The slender, vase-shaped panicles of spikes have a silky, white or pinkish cast because of the numerous long awns and fuzzy lemmas. The fertile lemma is about $3 \mathrm{~mm}$. long. The rudimentary floret is wedgeshaped and bears an awn about the same length as that of the fertile lemma. This species is found as a weed in fields, along roadsides and railroad tracks in the Southwest. The occurrences in the eastern states are probably introductions. In New England, the plants occur on wool waste heaps around woolen mills, the seeds being imported in the raw fleeces. July-September.

20a. Plants $1-1.5 \mathrm{~m}$. tall; leaf blades tapering to long, fine points. Fig. 265.

RHODES GRASS

Chloris gayana Kunth

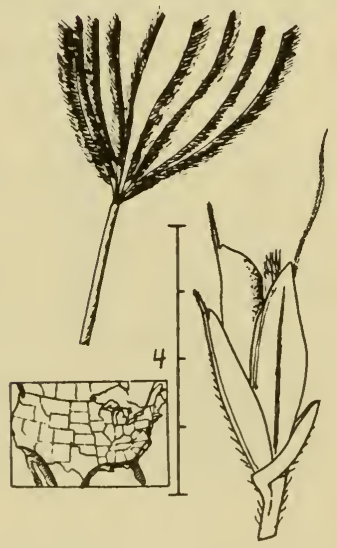

Perennial; spreading by leafy stolons; panicles vase-shaped, $5-10 \mathrm{~cm}$. long; spikelets yellowish, each with two rudimentary florets above the fertile one. Rhodes grass is grown in the southern states for hay and grazing and is found growing wild in fields and on waste ground. It winter kills at 20 degrees $F$., and so is adapted only to the far South. Introduced from Africa. 
20b. Plants $20-50 \mathrm{~cm}$. tall; leaf blades with blunt tips. Fig. 266 . WINDMILL GRASS Chloris verticillata Nutt.

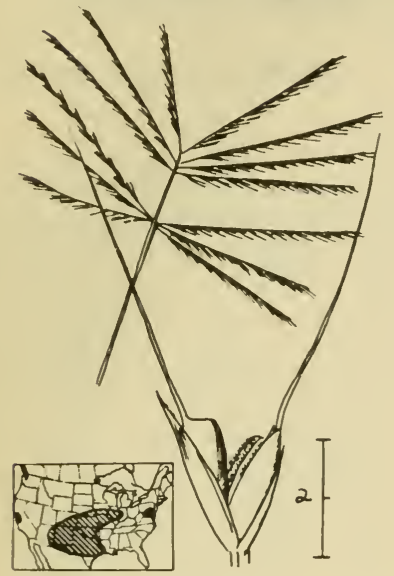

Figure 266

Perennial; culms tufted or with short stolons; leaf sheaths flattened and keeled; ligule membranous and ciliate, short; leaf blades grayish-green, $1-3$ $\mathrm{mm}$. wide; panicles of 2 or 3 whorls of stiff, widely-spreading spikes, each 5 $15 \mathrm{~cm}$. long. Spikelets rather widely spaced, the spikes slender; spikelets around $3 \mathrm{~mm}$. long; awns $5-8 \mathrm{~mm}$. long; fertile lemma hairy on the nerves; rudimentary lemma blunt. Windmill grass is primarily a plant of the plains of the Southwest, but may appear occasionally as a waif in the North. The mature panicles break off and roll as tumbleweeds. June-September.

2la. Inflorescence of $1-10$ spikes, which remain on the plant; florets

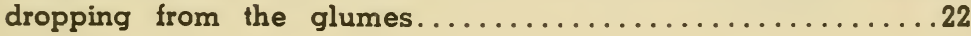

2lb. Inflorescence of numerous spikes, arranged in a slender raceme; entire spikes falling from the rachis whole when ripe. Fig. 267.

SIDE-OATS GRAMA

Bouteloua curtipendula (Michx.) Torr.

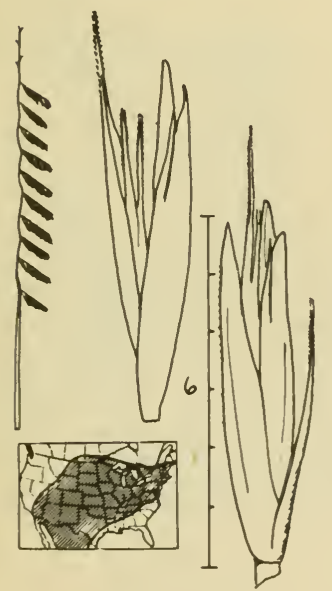

Figure 267

Perennial; culms in tufts, arising from slender rhizomes. The plants range up to $80 \mathrm{~cm}$. in height, most of the height being the long raceme of drooping spikes. Late in the season all of the spikes drop from the flattened rachis, which remains, bearing only the short stalks of the spikes. Side-oats is a very attractive grass, with brilliant orange anthers, contrasting with the usually purple spikes. The name "sideoats" refers to the fact that most of the spikes droop toward one side of the rachis. This is one of the most valuable forage grasses in the western states, furnishing good feed yearlong. Dry plains and open rocky hillsides, from near sea level to $2700 \mathrm{~m}$. June-September. 
22a. Plants erect or spreading; internodes of the culms not woolly . .23

22b. Plants producing elongate stolons, the internodes covered with conspicuous short white wool. Fig. 268.

BLACK GRAMA

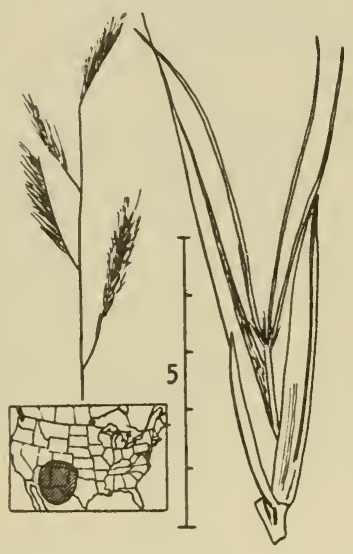

Bouteloua eriopoda Torr.

Figure 268

23a. Rachis of the spike bearing spikelets to the tip; keels of glumes usually not black-dotted............................. 4

23b. Rachis of the spike extending beyond the spikelets as a naked point 5-8 $\mathrm{mm}$. long; keel of the second glume bearing prominent black dots. Fig. 269. HAIRY GRAMA

Bouteloua hirsuta Lag.

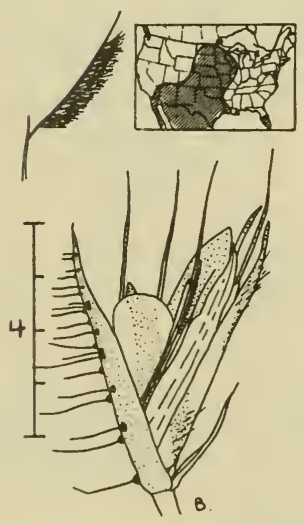

Perennial; tufted; culms $20-60 \mathrm{~cm}$. tall; leaves short, curly, mostly at the base of the plants. Hairy grama is a highly prized forage grass, widespread west of the Mississippi, especially on dry plains and hills, from $670-1800 \mathrm{~m}$. elevation. In the Middle West it is usually found on dry hilltops. Hairy grama furnishes good feed yearlong, but is especially valued for wintertime use. JulyOctober. 
24a. Spikes 3-7 per culm, each $1-2 \mathrm{~cm}$. long; keels of glumes without long hairs; shallow-rooted annual plants with soft bases. Fig. 270. SIX-WEERS GRAMA Bouteloua barbata Lag.

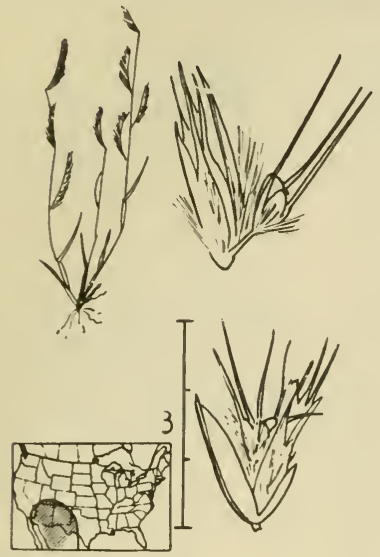

Annual; culms $10-30 \mathrm{~cm}$. long, in small tufts, erect or more commonly spreading out and forming flat mats. The seeds germinate after rains, and the plants mature and die rapidly, hence the name "six-weeks grama." The sixweeks grasses, belonging to a number of genera, furnish short-season feed after heavy rains, but their total forage production is small and they are highly undependable as forage plants. Dry plains, especially on overgrazed pastures. July-October.

Figure 270

24b. Spikes $1-3$ per culm, each $2.5-5 \mathrm{~cm}$. long; keels of second glumes bearing scattered long hairs; perennial, with hard bases. Fig. 271.

BLUE GRAMA

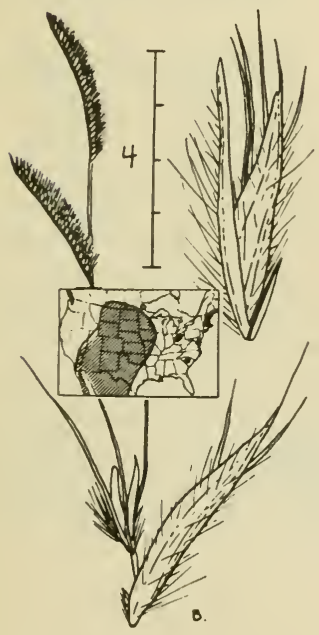

Bouteloua gracilis (H. B. K.) Lag.

Perennial; tufted; culms $20-100 \mathrm{~cm}$. tall; most of the curly leaves are at the base of the plant. Blue grama is an excellent forage grass on the Great Plains and in the western mountains, furnishing good feed both summer and winter. Open plains, open or lightly timbered mountainsides. It may be confused with buffalo grass (Fig. 247), with which it often grows, but blue grama lacks the creeping stolons of buffalo grass. June-October. 


\section{TRIBE VIII. PHALARIDEAE}

1a. Lower florets less than half as long as the fertile floret and closely

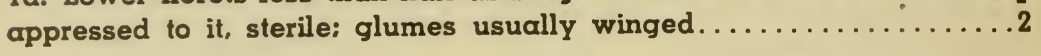

1b. Lower florets as long as the fertile floret or longer...........

2a. Plants producing rhizomes; panicles cylindrical and often lobed. Fig. 272.

REED CANARY GRASS

Phalaris arundinacea L.

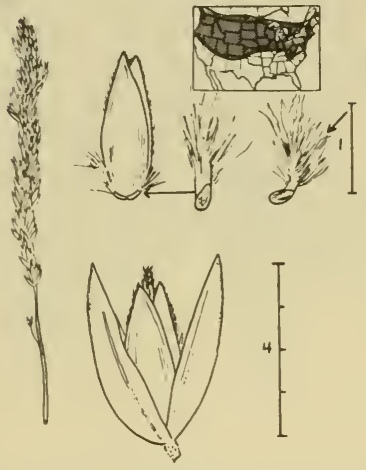

Figure 272

Perennial; plants $60-150 \mathrm{~cm}$. tall, with pale or purplish panicles, 7-16 $\mathrm{cm}$. long. The tall, broad-leaved plants furnish considerable forage and are often cut for hay. They form dense colonies in marshes and along ditches. Reed canary grass is now planted for erosion control on farm waterways. May-August. Forms with white-striped leaves are sometimes grown for ornament, under the name of "gardeners garters."

2b. Plants tufted, lacking rhizomes; panicle dense, thimble-shaped. Fig. 273.

CANARY GRASS

Phalaris canariensis L.

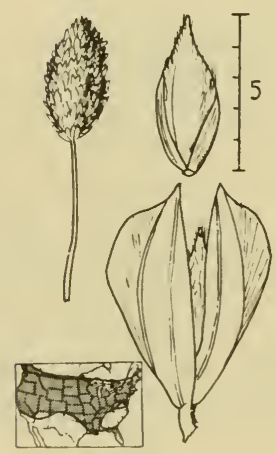

Figure 273
Annual; tufted; culms $30-60 \mathrm{~cm}$. tall; panicles $1-4 \mathrm{~cm}$. long. The strongly winged glumes are striped with green and white lines. This is the species which furnishes the "canary seed" which is fed to caged birds. The plants are found occasionally growing on trash heaps where the sweepings from bird cages are deposited, but this species apparently does not grow as a truly wild plant in this country. Introduced from Europe. June -August. 
3a. Lower 2 florets awned, sterile. Fig. 274.

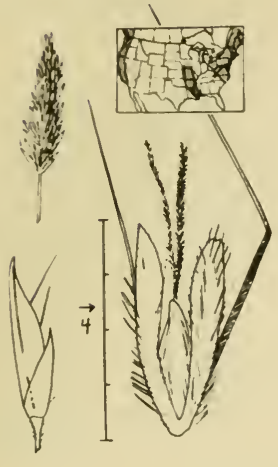

Figure 274

Perennial; tufted; plants $30-60 \mathrm{~cm}$. tall; panicles yellowish-brown, cylindrical, dense, usually less than $6 \mathrm{~cm}$. long; glumes very thin and delicate. The 2 hairy sterile lemmas are split at the tip and awned from the middle of the back. Sweet vernal grass has the delightful fragrance of coumarin, which persists long after the plants are dried. This species was introduced from Europe, presumably as a meadow plant to add fragrance to hay. Now it is widely established as a weed of roadsides, woods, and meadows, except in the dry parts of the United States. It is one of the earliest of spring grasses, blooming from the middle of April to July in the northern states.

3b. Lower 2 florets awnless, staminate. Fig. 275. HOLY GRASS

Hierochloe odorata (L.) Beauv.

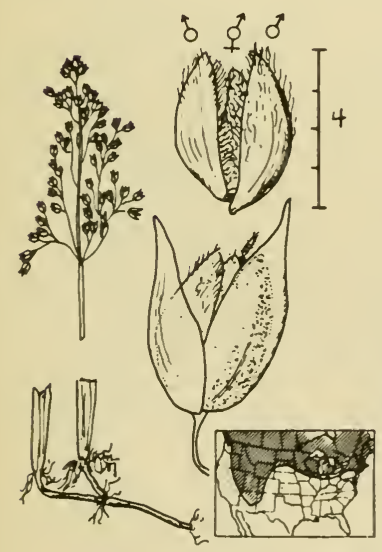

Perennial; culms $30-60 \mathrm{~cm}$. tall, single or in small tufts, arising from slender creeping rhizomes. Holy grass is an attractive species, with handsome shining golden brown panicles. The glumes are very thin and translucent. The plants have the sweet, vanilla-like scent of coumarin, and were used by the American Indians as material for basketry, and in Europe as perfume in certain religious ceremonies. Moist meadows, bogs, and prairies. AprilJuly.

Figure 275 


\section{TRIBE IX. ORYZEAE}

1a. Spikelets with evident "glumes," about $1 / 3$ as long as the lemma and palea. Fig. 276.

RICE

Oryza sativa L.

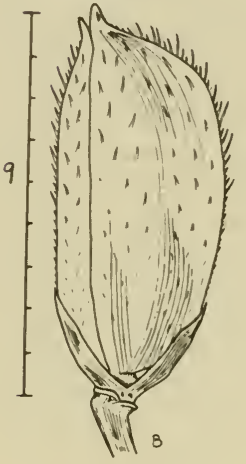

Figure 276

Annual; plants aquatic, stout, $1-2 \mathrm{~m}$. tall; panicles drooping, the very flat spikelets hairy, awned or awnless. The structures which look like glumes are really sterile lemmas; the true glumes are the minute ridges which are left behind at the summit of the pedicel when the floret drops. Rice is one of the principal food crops of the world but its culture is restricted to moist or irrigated regions with warm temperate or tropical climates. In the United States, it is grown only in the lower Mississippi Basin and in Florida and California.

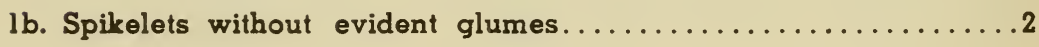

2a. Sheaths strongly downwardly scabrous; rhizomes slender, with exposed internodes; lower panicle branches whorled. Fig. 277.

CUT GRASS

Leersia oryzoides (L.) Sw.

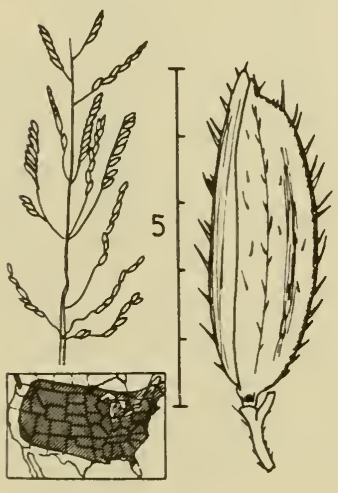

Figure 277

Perennial; culms up to $1.5 \mathrm{~m}$. long; weak and often sprawling; rhizomes long and slender; leaf sheaths and margins of the blades armed with very sharp minute spines which can scratch severely. The plants are very rough to the touch and cling readily to clothing. The glumes of species of Leersia are the minute cup-like structures from which the floret drops. Cut grass often forms dense "jungles" along streams or around ponds or in marshes. July-October.

Leersia lenticularis Michx. (CATCHFLY GRASS) is similar, but has broadly oval spikelets, 3-4 $\mathrm{mm}$. wide and $4-5 \mathrm{~mm}$. long, arranged in neat overlapping rows.

Wet ground and swamps, Mississippi Valley and southecstern states. 
2b. Sheaths smooth or nearly so; rhizomes short and thick, densely covered with scales: lower panicle branches borne singly. Fig. 278.

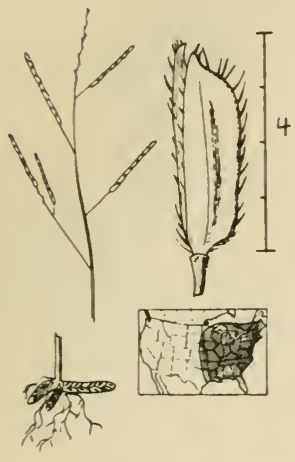

Figure 278
Perennial; culms $50-120 \mathrm{~cm}$. tall, weak and slender; panicle $10-20 \mathrm{~cm}$. long, with a few simple branches, the spikelets lying closely parallel to them. Some of the smaller panicles may be hidden in the sheaths. Leaf blades yellowish green. Damp woods and thickets; mud flats. July-October.

\section{TRIBE $X . \quad$ ZIZANIEAE}

1a. Plants growing immersed in water, the upper leaves $1-5 \mathrm{~mm}$. wide, floating on the water surface. Fig. 279.

WATER GRASS

Hydrochloa carolinensis Beauv.

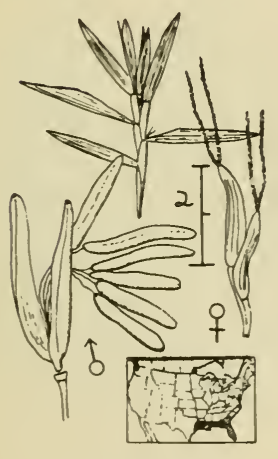

Perennial; culms slender, weak, up to 1 $\mathrm{m}$. long, floating in water, the upper leaves on the surface. The staminate spikelets are borne at the tips of branches and the pistillate ones in the axils of leaves. Neither type has evident glumes, and both have only $a$ single floret. Ponds and slow streams. Furnishes some feed for livestock. Blooming apparently rarely. June-August. 
1b. Plants with erect tall culms, $1-3 \mathrm{~m}$. tall; leaf blades $1-4 \mathrm{~cm}$.

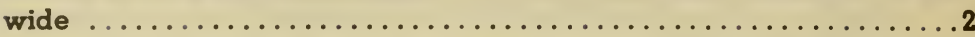

2a. Pistillate spikelets all at the upper tip of the panicle, forming an erect brush; awns of the pistillate spikelets several times as long as the lemma; staminate spikelets all on spreading lower branches of the panicle. Fig. 280.

WILD RICE.

Zizania aquatica L.

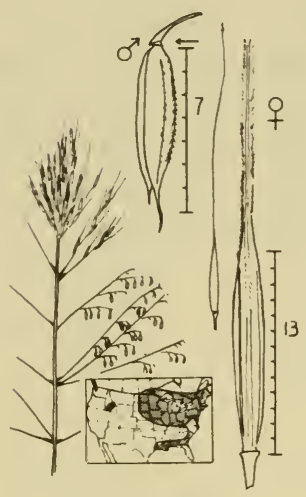

Figure 280

Annual; culms stout, $2-3 \mathrm{~m}$. or more tall; panicles $30-50 \mathrm{~cm}$. long, open and pyramidal. The spikelets consist of single florets, which disarticulate from minute cup-like structures which are the vestiges of glumes. Wild rice was an important food plant for the American Indians, who threshed the standing plants into canoes. It still furnishes some food for human beings and the grain can occasionally be purchased in stores. In nature, wild rice is an important producer of food for water fowl. Shallow water, ditches, ponds, streams and marshes. July-September.

2b. Pistillate spikelets intermixed with the staminate ones on the same branches; awns of pistillate spikelets not longer than the lemma. Fig. 281.

SOUTHERN WILD RICE Zizaniopsis miliacea (Michx.) Doell.

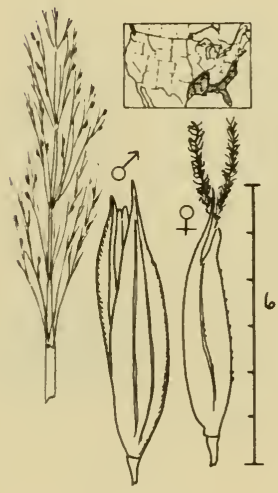

Perennial; plants $1-3 \mathrm{~m}$. tall or taller, the culms arising from stout rhizomes; panicles nodding, $30-50 \mathrm{~cm}$. long. Leaves very scabrous on the margins. The spikelets consist of single florets, which disarticulate from the vestigial glumes, as in the previous species. The staminate ones have 6 stamens instead of the usual 3. Marshes and along streams. May-June. 


\section{TRIBE XI. PANICEAE}

la. Spikelets inclosed in spiny burs. Fig. 282.

FIELD SANDBUR

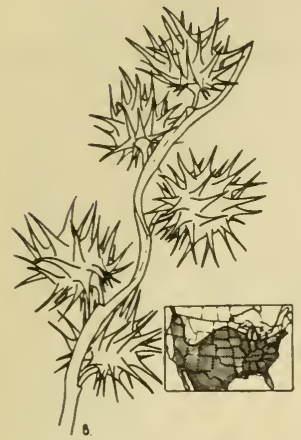

Figure 282

Cenchrus pauciflorus Benth.

Annual; culms $20-90 \mathrm{~cm}$. long, usually spreading and making mats. The spikelets are mostly concealed by the horribly spiny burs, which are made up of sterile branches. The burs are borne in short spikes along a zig-zag rachis, and fall off at a touch when ripe. The spines of the burs are very sharp, and each spine is microscopically backwardly-barbed. These spines can inflict painful and dangerous flesh wounds. Each bur contains one to several spikelets, which resemble those of species of Panicum. Sandbur is an undesirable weed of disturbed soil, much more common on sandy land than on heavier soils. Where it is abundant, it may furnish some feed for livestock when young. May-October.

Cenchrus tribuloides L. (DUNE SANDBUR) has larger burs, 10-17 $\mathrm{mm}$. in diameter. It grows on dunes along the Atlantic and Gulf Coasts.

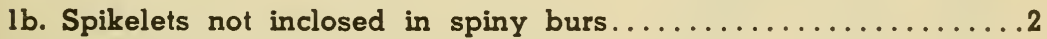

2a. Spikelets imbedded in one side of an erect, unbranched, flattened, corky rachis. Fig. 283.

ST. AUGUSTINE GRASS Stenotaphrum secundatum (Walt.) Kuntze

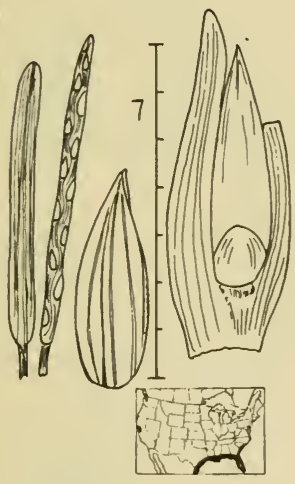

Perennial; plants spreading rapidly and extensively by stolons; erect flowering stems $10-30 \mathrm{~cm}$. tall. The leaf sheaths are very much flattened and keeled; blades with rounded, blunt tips. The spikelets are similar to those of Panicum species, but are nearly hidden by the flanges of the rachis. The first glume and sterile lemma are exposed. This unique grass is used for lawns in some localities in the South. Occasionally plants occur with white-striped leaf blades, and these may be cultivated for ornament. June-September.

Figure 283

2b. Spikelets not sunken into the rachis.................... 
3a. Each spikelet accompanied by one to many bristles, which are attached below it; panicles dense, bristly, spikelike...........

3b. Spikelets without accompanying bristles, borne in open or dense

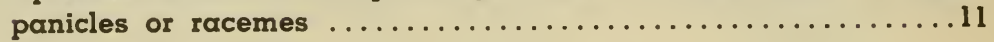

4a. Spikelets (or florets) falling, leaving the bristles on the plant...5

4b. Spikelets falling individually or in groups, with the bristles attached to the spikelets. Fig. 284.

FOUNTAIN GRASS

Pennisetum setaceum (Forsk.) Chiov.

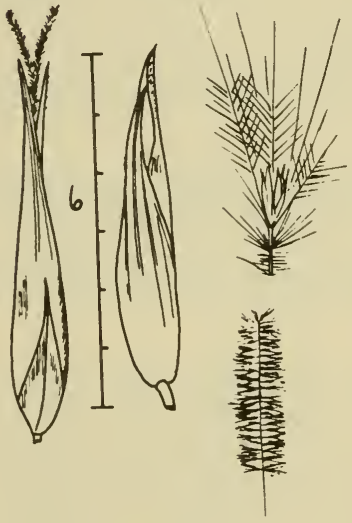

Figure 284

Perennial; tufted; culms up to $1 \mathrm{~m}$. tall, with a hairy, pinkish or lavender, spikelike panicle. The panicle is made up of a straight central axis, $15-35 \mathrm{~cm}$. long, bearing dense clusters of short branches. At maturity, each branch breaks off, carrying with it a spikelet or a small group of spikelets, surrounded by a dense tuft of long $(3-4 \mathrm{~cm}$.) bristles. The larger bristles may have branches, feather-fashion. This is a handsome ornamental grass, introduced from Africa. Summer. Formerly known as $P$. ruppelii.

Pennisetum glaucum (L.) R. Br. (PEARL MILLET) has a thick spike, looking like that of the cat-tails. Rarely cultivated for forage in the South. Plants up to $2 \mathrm{~m}$. tall. Bristles of the spikelet-groups short, barely reaching the tips of the spikelets.

5a. Bristles upwardly-barbed or smooth; panicles not clinging to objects 
5b. Bristles downwardly-barbed, clinging to objects when the panicle is brushed upward. Fig. 285.

BRISTLY FOXTAIL

Setaria verticillata (L.) Beauv.

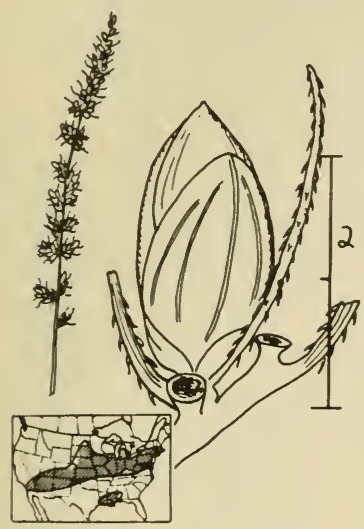

Annual; tufted; culms up to $1 \mathrm{~m}$. tall. The barbed bristles of the panicles not only cause them to adhere to wool, hair, or clothing, but also to each other. After windstorms, the plants will often be densely tangled. Sometimes flies or other insects become caught in the bristles. Common in cornfields and on disturbed soil. June-October. Introduced from Europe.

Figure 285

6a. Margins of sheaths bearing short hairs................

6b. Margins of sheaths smooth, thin and translucent; glabrous except for a few long hairs at the apex. Fig. 286.

YELLOW FOXTAIL

Setaria lutescens (Weigel) Hubb.

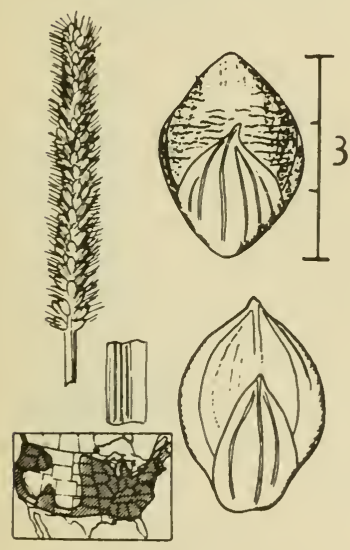

Figure 286

Annual; tufted; culms spreading or erect, up to $1 \mathrm{~m}$. tall; panicles stiff and compact, with a pronounced golden cast, imparted by the yellow bristles; back of the fertile lemma exposed, transversely corrugated. An exceedingly common weed, in cornfields or other disturbed soil. July-October. Introduced from Europe. Also known as S. glauca.

Setaria geniculata (Lam.) Beauv. has similar panicles but is a perennial, and the culms arise singly or in small tufts from knotty, much-branched rhizomes. Atlantic and Gulf Coast states, from Massachusetts to Texas, lower Mississippi Valley to Illinois and Iowa. 
7a. Upper surfaces of leaves glabrous..................

7b. Upper surfaces of leaves covered with soft hairs. Fig. 287. NODDING FOXTAIL

Setaria faberii Herrm.

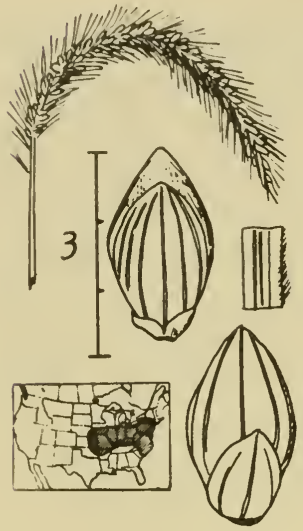

Annual; tufted; culms up to $2.5 \mathrm{~m}$. tall; spikelets $2.6-2.9 \mathrm{~mm}$. long. This species looks much like green foxtail, but is usually larger and has more drooping, larger panicles. The velvety leaf blades are a good mark of recognition. Although known in North America for only about twenty years, nodding foxtail is already a bad weed in parts of the eastern and middle western states. Corn, soybean, and red clover fields; gardens; disturbed soil, especially on river bottomlands. July-September. Introduced from China.

Figure 287

8a. Spikelets dropping from the plants whole..............

8b. Fertile floret when ripe "shelling out" of the glumes and sterile lemma, leaving them attached to the plant. Fig. 288.

FOXTAIL MILLET

Setaria italica (L.) Beauv.

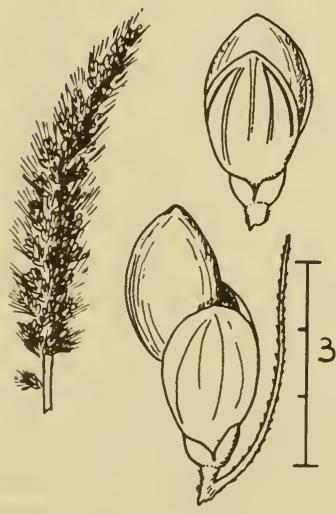

Annual; tufted; plants stout, often $1 \mathrm{~m}$. or more tall, with large, often definitely lobed panicles. Foxtail millet is regarded as being closely related to the wild green foxtail. The fertile lemma is variously yellow, orange, red, brown, or blackish. Millet is cultivated to a small extent as a forage and grain crop. It is sometimes found persisting after cultivation or as a stray in the wild. Introduced from the Orient. July-October. 
9a. Plants usually $1 \mathrm{~m}$. tall or shorter; leaf blades usually $1 \mathrm{~cm}$. wide or narrower: plants widespread, not in coastal marshes........10

$9 \mathrm{~b}$. Plants $1-4 \mathrm{~m}$. tall; larger leaf blades $1-4 \mathrm{~cm}$. wide; plants of coastal marshes along the Atlontic and Gulf of Mexico. Fig. 289. GIANT FOXTAIL

Setaria magna Griseb.

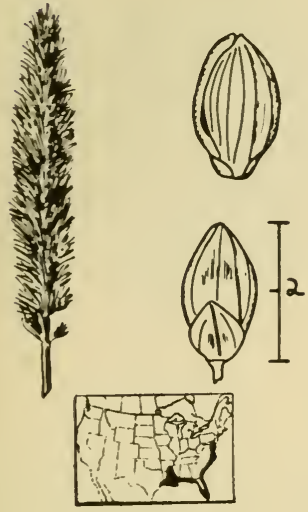

Figure 289

Annual; tufted; culms stout and tall, up to $2 \mathrm{~cm}$. thick and $4 \mathrm{~m}$. tall; leaf blades flat and scabrous, up to $50 \mathrm{~cm}$. long. The immense panicles reach lengths of $50 \mathrm{~cm}$. and diameters of $3.5 \mathrm{~cm}$. They are somewhat nodding and may be lobed at the base, thickest at the middle and tapering toward the ends. Axillary panicles are much smaller than the terminal one. Bristles 1-2 cm. long; spikelets about 2 $\mathrm{mm}$. long; fertile floret smooth and shining, brown when ripe. Giant foxtail is a characteristic plant of coastal marshes, found in the interior only in Arkansas. Its range also extends to the West Indies. August-September.

10a. Plants annual, with soft bases and shallow roots; leaf blades usually less than $15 \mathrm{~cm}$. long, flat; panicles usually less than $10 \mathrm{~cm}$. long, with dense spreading bristles. Fig. 290.

\section{GREEN FOXTAIL}

Setaria viridis (L.) Beauv.

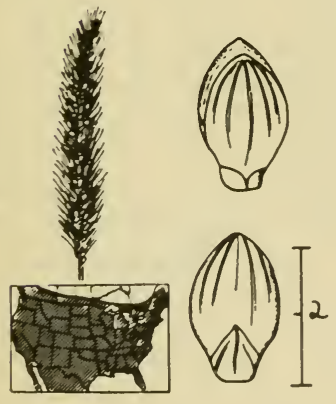

Figure 290

Annual; tufted; becoming much-branched from the base, $20-100 \mathrm{~cm}$. tall; leaf sheaths glabrous except for the short cilia along the margins; blades glabrous, usually less than $10 \mathrm{~mm}$. wide; panicles soft, slightly nodding near the tip; bristles green, rarely purple; spikelets $1.9-2.2 \mathrm{~mm}$. long, greenish except when ripe; second glume and sterile lemma nearly covering the fertile floret; fertile lemma nearly smooth. Green foxtail is one of the commonest weeds of cornfields and other areas of disturbed soil. The bristles are sterile panicle branches. July-October. Introduced from Europe. 
10b. Plants perennial, with hard, knotty crowns; leaf blades usually folded, 15-40 cm. long; panicles slender, 2-25 cm. long, with sparse bristles. Fig. 291.

PLAINS FOXTAIL

Setaria macrostachya H. B. K.

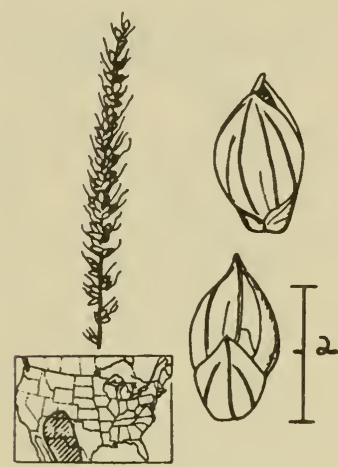

Perennial; in hard tufts; culms $40-120$ $\mathrm{cm}$. tall; panicles slender, with the hairy rachis exposed between clusters of spikelets. The plants are leafy and are highly palatable to livestock, so that they are usually kept grazed down except in clumps of spiny bushes. Dry plains and savannas, especially along roadsides or other areas protected from grazing. AprilOctober.

Figure 291

11a. Spikelets covered with long, silky, white or brownish or rosy

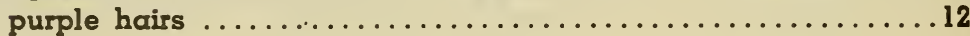

11b. Spikelets smooth or hairy with short hairs, or silky on the mar-

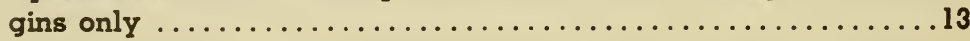

12a. Spikelets laterally compressed; second glume and sterile lemma awned; hairs rosy purple. Fig. 292.

NATAL GRASS; RUBY GRASS

Rhynchelytrum roseum (Nees) Stapf \& Hubb.

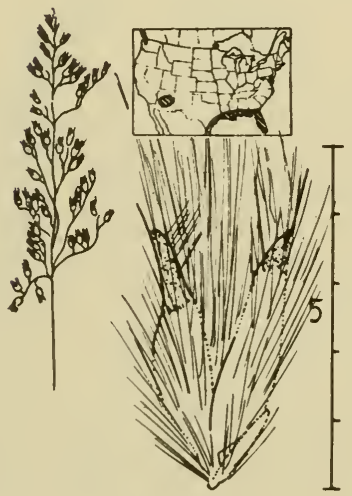

Figure 292
Perennial; tufted; plants about $1 \mathrm{~m}$. tall; panicles rosy-purple, $10-15 \mathrm{~cm}$. long; spikelets on bent or curled pedicels, and densely covered with purple hairs. The second glume and sterile lemma have short awns, which are concealed by the hairs. The lateral compression of the spikelets is very atypical for the Panicoideae. Dry sandy land and open woods. Natal Grass, an introduction from Africa, is grown in Florida for forage and has become naturalized there and also along the Gulf Coast. Winter. Formerly known as Tricholaena rosea. 
12b. Spikelets dorsally compressed, awnless; hairs white. Fig. 293. COTTONTOP

Trichachne californica (Benth.) Chase

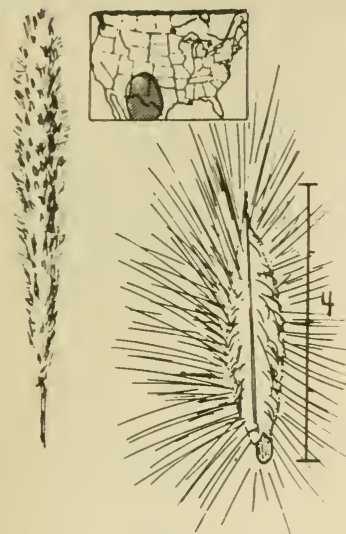

Perennial; tufted, from knotty stooling crowns; plants $30-100 \mathrm{~cm}$. tall, with rather dense, slender panicles $5-10 \mathrm{~cm}$. long. The panicles have a silvery white color, rarely tinged with purple when young; spikelets with a minute first glume; second glume shorter and narrower than the fertile lemma. Cottontop furnishes good summer and winter feed in the Southwest, but is grazed mostly just after rains, when it makes rapid growth. Rocky ridges, margins of fields, in brush. August-October.

Figure 293

13a. Spikelet without a cup or ring at the base; first glume present

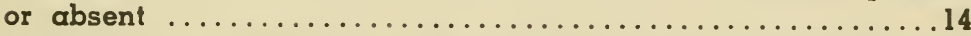

13b. Spikelet with $\alpha$ cup- or ring-like swelling at the base, without an evident first glume. Fig. 294.

PRAIRIE CUP GRASS

Eriochloa contracta Hitch.

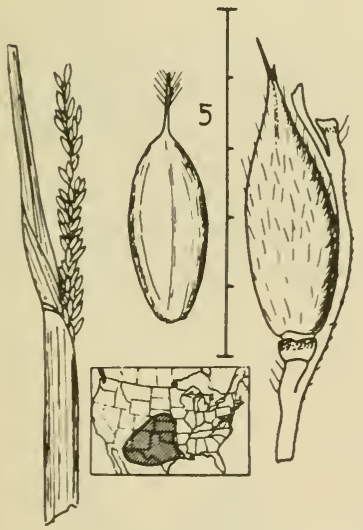

Figure 294

Annual; tufted; culms sometimes decumbent; plants $30-70 \mathrm{~cm}$. tall. The panicles are slender, made up of nearly erect racemes. The cup-like swelling at the base of the spikelet is a modified first glume. The fertile floret is somewhat shorter than the sterile lemma and bears a short, hairy awn which is concealed within the spikelet. Open ground, moist places, ditches. June-October. There are seven other species of this genus, all rather similar, in the southern states.

14a. Glumes or sterile lemma awned (the awn sometimes reduced to

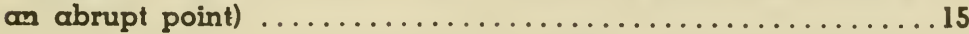

14b. Glumes and sterile lemma awnless.................. 16 
$15 \alpha$. Lower sheaths glabrous; fertile floret ovoid, 1.9-2.2 times longer than wide. Fig. 295.

BARNYARD GRASS

Echinochloa pungens (Poir.) Rydb.

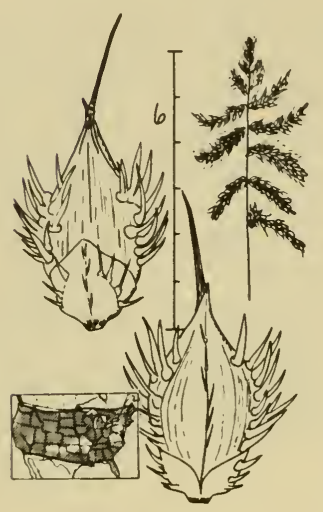

Figure 295

Annual; tufted; plants robust, up to 1.5 m. tall, with panicles up to $20 \mathrm{~cm}$. long, with spreading branches. The spikelets are covered with stout, spine-like hairs which arise from little yellowish blisters. Disturbed soil, in ditches, fields, marshes, borders of ponds. August-September.

Echinochloa crusgalli (L.) Beauv. is similar but does not have the blisterbased stout spines on the spikelets. Just below the withering tip of the fertile lemma is a circle of minute hairs. These are absent in the preceding species. Fields and waste places; widespread; supposedly introduced from Europe.

15b. Lower sheaths bristly with stiff hairs; fertile floret elliptical, 2.5 -3 times longer than wide. Fig. 296.

Echinochoa walteri (Pursh) Nash

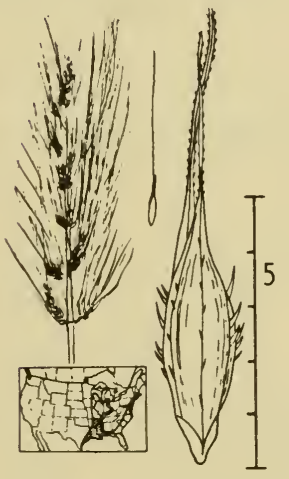

Annual; tufted; robust, up to $2 \mathrm{~m}$. tall; panicles up to $30 \mathrm{~cm}$. long. The spikelets usually bear awns $1-2.5 \mathrm{~cm}$. long. Individuals with glabrous sheaths can be identified by the narrow spikelets. Wet ground or shallow water, sometimes in brackish areas, mostly on the Atlantic and Gulf Coastal Plains. August-September.

Figure 296

16a. Spikelets borne in $1-4$ rows along the lower sides of one or more slender, spikelike racemes.......................

16b. Spikelets borne in open or dense panicles, not exclusively on the

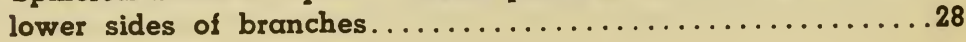


17a. First glume lacking or rudimentary, less than $1 / 10$ as long as the

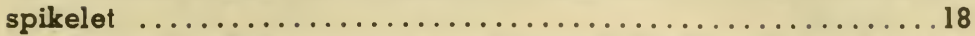

17b. First glume present, usually more than $1 / 3$ as long as the spikelet. Fig. 297.

Brachiaria platyphylla (Griseb.) Nash

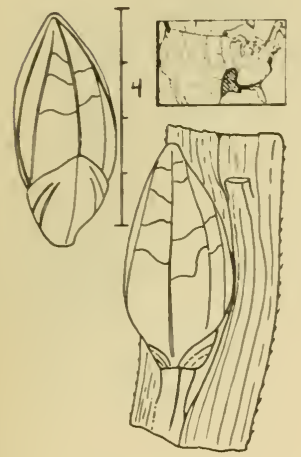

Figure 297

Annual; plants stooling out and sometimes rooting at the lower nodes; culms $25-40 \mathrm{~cm}$. or more long; leaf blades thickish, $4-12 \mathrm{~cm}$. long, 6-12 $\mathrm{mm}$. wide; rachis of the racemes flattened, 1-2 mm. wide; spikelets glabrous $4-4.5 \mathrm{~mm}$. long, the second glume and sterile lemma prolonged beyond the end of the fertile floret, forming a soft beak. Moist sandy ground. Summer. Formerly known as $B$. extensa.

Brachiaria ciliatissima (Buckl.) Chase has hairy foliage, and spikelets with woolly second glume and sterile lemma. It makes mats on dry sandy ground, the prostrate culms rooting at the nodes. Texas, Oklahoma, and Arkansas.

18a. Fertile floret soft and flexible; margins of the lemma not rolled

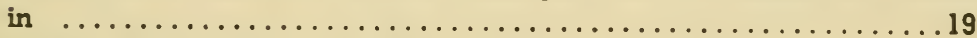

18b. Fertile floret hard and stiff; margins of lemma

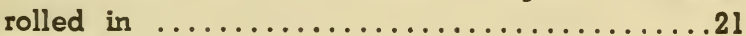

19a. Rachis of the racemes thin and flat, with a pronounced midrib. Fig. $298 \ldots \ldots \ldots \ldots \ldots \ldots 20$

19b. Rachis of the racemes triangular in cross section.

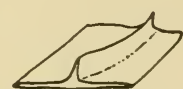

Figure 298 Fig. 299.

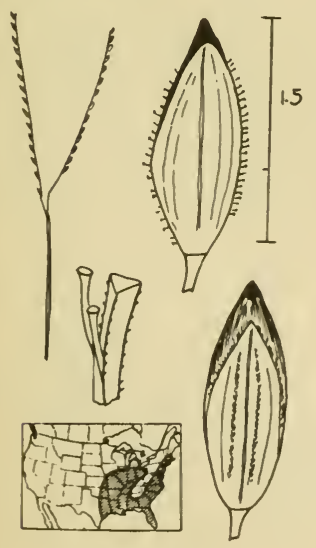

Digitaria filiformis (L.) Koel.

Annual; tufted; culms erect, $10-60 \mathrm{~cm}$. tall; racemes $1-5$, up to $10 \mathrm{~cm}$. long. The first glume is absent, and the equal second glume and sterile lemma nearly cover the chocolate brown fertile floret; spikelets about $1.5 \mathrm{~mm}$. long. Dry, usually sandy disturbed soil. August-October. 
20a. Fertile floret brownish-black when ripe; leaf sheaths glabrous. Fig. 300.

SMOOTH CRABGRASS Digitaria ischaemum (Schreb.) Muhl.

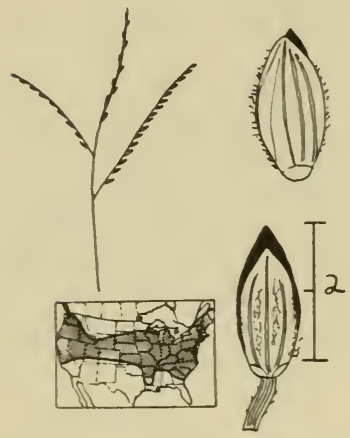

Annual; erect or spreading, often rooting at the lower nodes; culms usually 15 $-40 \mathrm{~cm}$. long; inflorescence usually of $2-6$ racemes. This species frequently grows with the next and is a bad weed in lawns. Disturbed soil, fields, waste places, gardens, lawns. August-October. Introduced from the Old World.

Figure 300

20b. Fertile floret pale or leaden gray when ripe; leaf sheaths sparsely to densely covered with long straight hairs. Fig. 301.

CRABGRASS

Digitaria sanguinalis (L.) Scop.

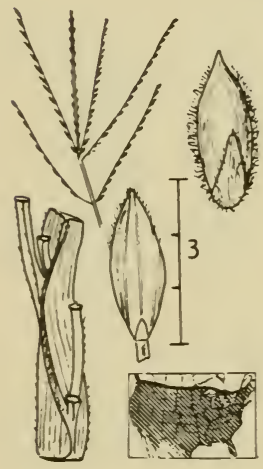

Figure 301

Annual; erect or spreading, usually rooting at the lower nodes; culms up to $1 \mathrm{~m}$. long, the plants often forming large mounds on rich soil. Crab grass is a serious weed in lawns. Being originally from warm climates, it starts growth when hot weather arrives. The rampant plants soon make large patches in lawns, but die out after the first frosts. They also grow abundantly in fields and waste places, sometimes furnishing some forage. July-October. Introduced from the Old World.

21a. Spikelets placed with the back (convex side)

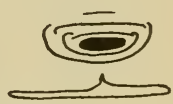
of the fertile lemma toward the rachis of the Figure 302 raceme. Fig. $302 \ldots \ldots \ldots \ldots \ldots \ldots \ldots 22$ 
21b. Spikelets placed with the fertile lemma turned away from the rachis of the raceme. Fig. 303.

CARPET GRASS

Axonopus affinis Chase

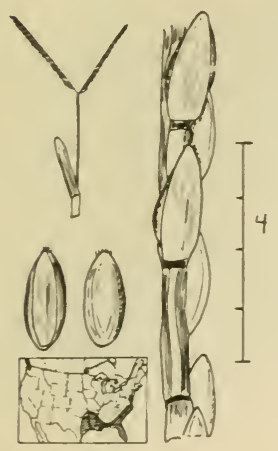

Figure 303

Perennial; producing extensive creeping stolons; erect culms flattened, $20-60 \mathrm{~cm}$. tall; racemes $2-5$ on each peduncle, $3-10 \mathrm{~cm}$. long; rachis triangular in cross section, with the spikelets fitting closely against it. The first glume is absent. Low moist sandy or muck soil on the coastal plain, where it is important as a lawn and pasture grass. March -September.

22a. Plants with creeping stems; aquatic or on wet ground......23

22b. Stems not creeping

23a. Leaf blades, sheaths, and spikelets completely glabrous; spikelets about $2 \mathrm{~mm}$. long. Fig. 304 .

Paspalum dissectum L.

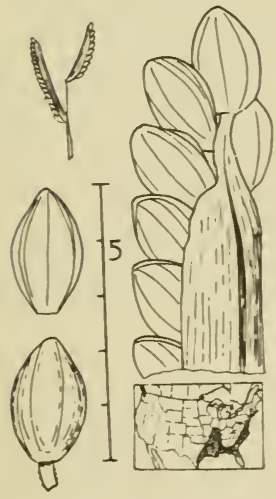

Perennial; plants creeping by extensive stolons; erect culms $20-60 \mathrm{~cm}$. tall, bearing $2-5$ racemes, each $2-3 \mathrm{~cm}$. long; leaf blades dark green, $3-6 \mathrm{~cm}$. long, 4-5 $\mathrm{mm}$. wide. The rachis of the raceme is flat and thin, $2-3$ $\mathrm{mm}$. wide. The first glume is lacking. Muddy flats and ditches and in shallow water. August-October. 
23b. Leaf sheaths with tufts of hairs on the auricles; second glume minutely hairy; spikelets $2.5-3.5 \mathrm{~mm}$. long. Fig. 305 .

KNOTGRASS

Paspalum distichum L.

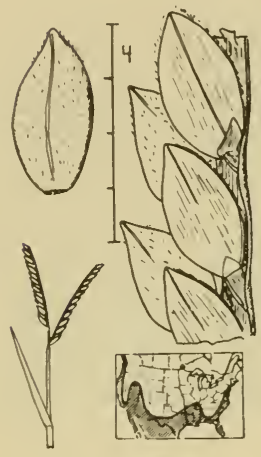

Figure $\supseteq 05$

Perennial; spreading by long creeping stolons; erect culms $8-50 \mathrm{~cm}$. tall; inflorescence of 2 or rarely 3 racemes, each $2-7 \mathrm{~cm}$. long and somewhat curved, attached together at the summit of the culm; spikelets often with a minute first glume. Knotgrass forms large flat mats in ditches and on shores of rivers and ponds, usually in fresh water areas, rarely also in brackish localities. May-September. Found also in South America and Europe.

24a. Inflorescences borne at the tips of the culms and in the axils of the sheaths (sometimes hidden within the sheaths)........25

24b. Inflorescences borne only at the tips of the culms, none in the

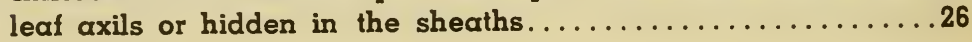

$25 \alpha$. Spikelets $1.5-1.8 \mathrm{~mm}$. long, minutely hairy or glabrous. Fig. 306. Paspalum setaceum Michx.

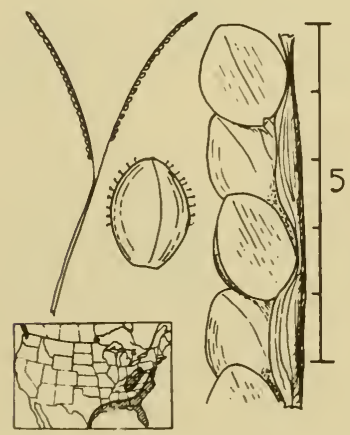

Figure 306

Perennial; tufted from a knotty crown; plants $30-50 \mathrm{~cm}$. tall; hairy; culms slender and erect; leaf sheaths hairy; blades up to $12 \mathrm{~cm}$. long and 2-6 $\mathrm{mm}$. wide, hairy on both surfaces and the edges; inflorescence of 1 or 2 slender, arched racemes, 5-7 cm. long; first glume of spikelets lacking. Dry sandy soil and open woods, especially on the Atlantic and Gulf Coastal Plains. July-September.

Paspalum debile Michx. has spreading culms, densely grayish hairy foliage, and minutely hairy spikelets, 1.8-

$1.9 \mathrm{~mm}$. long. Most of the foliage is at the base of the plant; upper leaves short. Sandy woods of the Atlantic and Gulf Coastal Plains; Long Island to Mexico and Cuba. 
25b. Spikelets 2-2.4 mm. long. Fig. 307.

Paspalum pubescens Muhl.

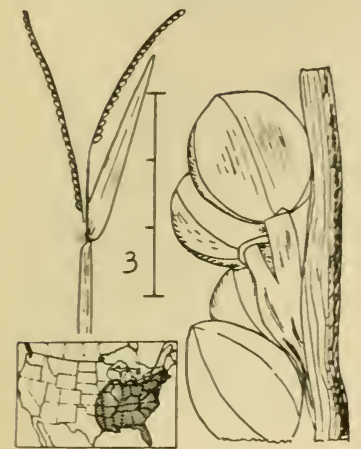

Figure 307

Perennial; tufted; plants $40-90 \mathrm{~cm}$. tall, hairy; inflorescence consisting of $1-3$ racemes, each $4-17 \mathrm{~cm}$. long; first glume absent. Old fields, meadows, waste ground, open woods, especially on sandy land. June-September. This is one of the commonest species, and extremely variable. There are about four closely related species found in parts of its range.

26a. Spikelets not fringed with long hairs.................. 27

26b. Spikelets fringed with long silky hairs, borne on the edges of the second glume. Fig. 308.

DALLIS GRASS

Paspalum dilatatum Poir

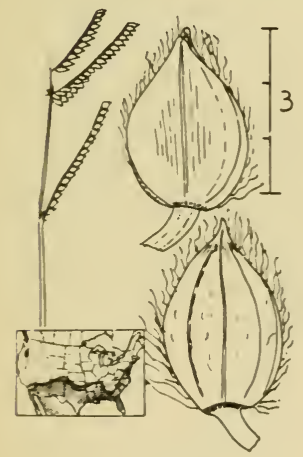

Figure 308

Perennial; tufted; plants $50-150 \mathrm{~cm}$. tall; inflorescence of $3-5$ racemes, each $6-8 \mathrm{~cm}$. long; first glume absent. The spikelets are more pointed than those of most other species. Dallis grass is a -aluable pasture grass in the southeastern states and under irrigation in the Southwest. The spikelets may become infected by an ergot fungus and hence become poisonous to cattle. Cultivated meadows and pastures and commonly escaped to the wild. May-September. Native to South America.

Paspalum urvillei Steud. (VASEY GRASS) is similar but has $12-20$ racemes and strongly hispid lower sheaths. Virginia to Florida, Arkansas and Texas; California. 
27a. Plants $1-2 \mathrm{~m}$. tall; spikelets $4-4.5 \mathrm{~mm}$. long. Fig. 309.

Paspalum floridanum Michx.

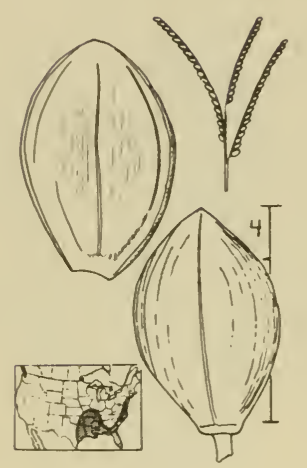

Figure 309

Perennial; culms single or in small tufts from short rhizomes; plants robust, $1-2 \mathrm{~m}$. tall; foliage hairy or glabrous; inflorescence of 2-5 racemes, each $4-12 \mathrm{~cm}$. long. The axis of the racemes is strongly zig-zag after the spikelets drop off. First glume absent. Low moist sandy barrens, Atlantic and Gulf Coastal Plains and northward in the interior. July-October.

27b. Plants less than $1 \mathrm{~m}$. tall; spikelets less than $3.2 \mathrm{~mm}$. long. Fig. 310.

Paspalum laeve Michx.

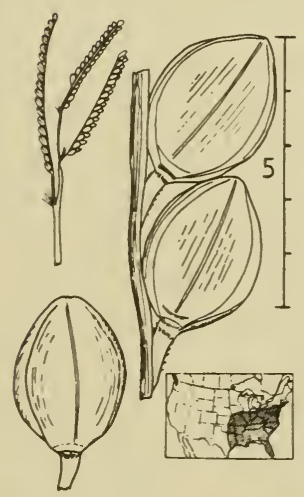

Perennial; tufted; plants $40-100 \mathrm{~cm}$. tall; foliage glabrous or hairy. The inflorescence consists of 3-4 racemes, each $3-10 \mathrm{~cm}$. long. The first glume is absent. This is a common species, varying greatly in hairiness of leaves and shape of spikelets. In typical plants, the spikelets are broadly oval. In var. circulare (Nash) Stone, they are nearly circular. Old fields, waste ground, meadow, open woods. July-October.

Figure 310

28a. Second glume not sack-like nor swollen at the base; fertile floret about as long as the second glume and sterile lemma........29 
28b. Second glume sack-like, swollen, the spikelet hence "lop-sided"; fertile floret about half as long as the sterile lemma. Fig. 311.

SACR GRASS

Sacciolepis striata (L.) Nash

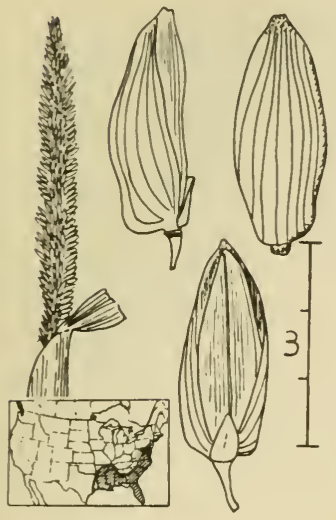

Perennial; culms often decumbent and rooting at the lower nodes, up to $2 \mathrm{~m}$. long. The leaf sheaths may be bristly-hairy or smooth. Panicles dense, cylindrical, 6$30 \mathrm{~cm}$. long. The spikelets are flat on the first glume side, very bulging at the base on the second glume side. Ditches, marshes and swamps, on the Atlantic and Gulf Coastal Plains. June-December.

Figure 311

29a. First glume absent or minute, less than $1 / 10$ as long as the spike-

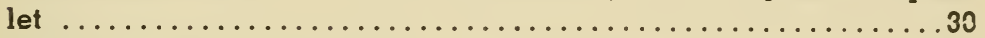

$29 b$. First glume present, usually at least $1 / 4$ as long as the spikelet.31

$30 a$. Spikelets hairy, 2-3 mm. long; no underground spikelets present. Fig. 312.

FALI WITCHGRASS

Leptoloma cognatum (Schult.) Chase

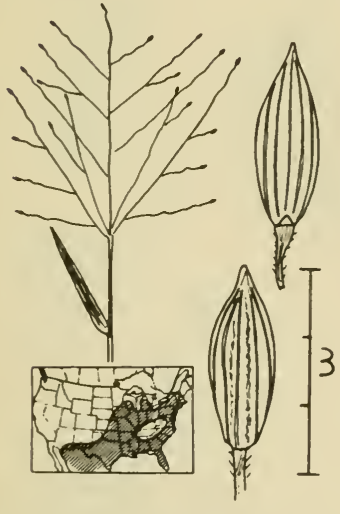

Figure 312
Perennial; plants stiffly spreading or erect, in large tufts; culms $30-70 \mathrm{~cm}$. long; panicles very open, with stiffly spreading, thin, somewhat zig-zag branches. The pedicels of the individual spikelets may be up to $20-30$ times the length of the spikelet. The second glume and sterile lemma bear appressed hairs. When mature, the panicles break off and roll away as tumbleweeds. Dry sandy open soil. May-September. 
30b. Spikelets glabrous, $4-7 \mathrm{~mm}$. long; underground spikelets present on leafless, root-like shoots. Fig. 313.

PEANUT GRASS

Amphicarpum purshii Kunth

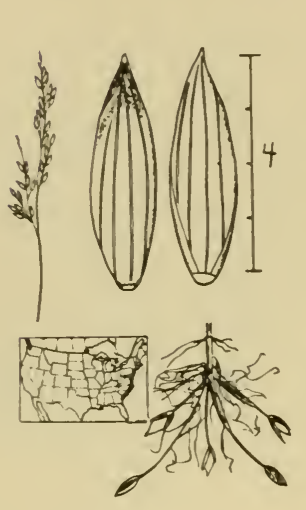

Figure 313

Annual; plants hairy, tufted, erect, $30-80$ $\mathrm{cm}$. tall. From the crown of the plant arise slender underground runners, $2-5 \mathrm{~cm}$. long, each bearing a single large spikelet, 7-8 $\mathrm{mm}$. long, at its tip. Most of the seed is produced by these underground spikelets, the aerial panicles being sterile. See also Fig. 330, which shows a subterranean spikelet. Sandy or peat soil, pine barrens of the Atlantic Coastal Plain. Fall.

Amphicarpum muhlenbergianum (Schult.) Hitch. is perennial, has smooth leaves and stout underground rhizomes, bearing subterranean spikelets. Pine barrens, South Carolina to Florida.

3la. Plants blooming twice, bearing panicles at the tips of the culms in spring or early summer, and small axillary panicles later; winter rosettes of short, broad leaves present in most species; all perennial species. Fig. $314 \ldots \ldots \ldots \ldots \ldots \ldots \ldots \ldots . \ldots . \ldots . \ldots . \ldots 2$

31b. Plants blooming once, all the panicles produced at the same period; winter rosettes not present; plants annual or perennial. .41

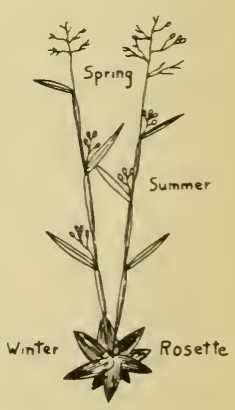

Figure 314

32a. Leat blades of the culms less than 15 times longer than wide; plants forming winter rosettes of short, broad leaves.........33 
32b. Leaf blades of the culms very narrow, 20 or more times longer than wide; plants without winter rosettes of broad leaves. Fig. 315.

Panicum depauperatum Muhl.

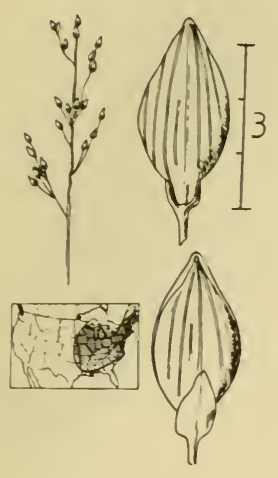

Figure 315

Perennial; tufted; plants $15-40 \mathrm{~cm}$. tall, with hairy or smooth leaf blades, up to 15 $\mathrm{cm}$. long and $2-5 \mathrm{~mm}$. wide. The terminal panicles, produced in May and June, are open, pyramid-shaped, and on long, slender peduncles. The secondary panicles consist of a few spikelets and are concealed among the basal leaf blades. The second glume and sterile lemma form an empty beak which protrudes beyond the tip of the fertile lemma. Open dry woods and barren ground. May -June.

33a. Ligules conspicuous, of straight hairs, $2-5 \mathrm{~mm}$. long.......34

33b. Ligules $1 \mathrm{~mm}$. or less long.......................

34a. Upper leaf sheaths glabrous; lower sheaths also usually glabrous; leaf blades glabrous or sometimes hairy on the edges only. Fig. 316.

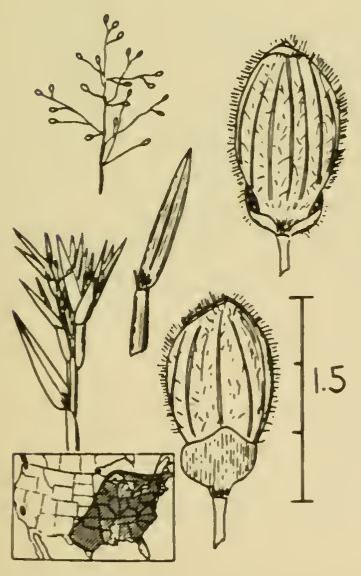

Panicum lindheimeri Nash

Perennial; tufted, at first rather slender, $30-100 \mathrm{~cm}$. tall. The plants later produce dense tufts of short, leafy branches, in the axils of the leaves, with small secondary panicles partially concealed among these leaves. The culms may then topple and the plants form flat circular mats. Terminal panicles blooming from May-July. Open dry ground and dry open woods. 
34b. Leaf sheaths and usually the blades conspicuously hairy. Fig. 317.

Panicum implicatum Scribn.

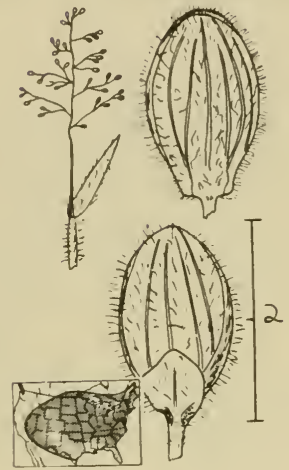

Perennial; tufted; plants $15-75 \mathrm{~cm}$. tall, with open, pyramid-shaped terminal panicles blooming in May and June. Later the plants become much-branched, with loose axillary tufts of short leafy branches, interspersed with the short secondary panicles. Roadsides, old fields, open woods, meadows, swamps. Very common and widespread. Panicum implicatum is usually broken up into a number of scarcely distinguishable "species" by other authors. P. columbianum (see Fig. 324) is quite similar.

Figure 317

35 a. Plants smooth or somewhat hairy, never velvety to the touch. 36

35b. Culms, leaf blades, and sheaths softly velvety to the touch, grayish; a smooth, sticky ring is present below each node. Fig. 318. Panicum scoparium Lam.

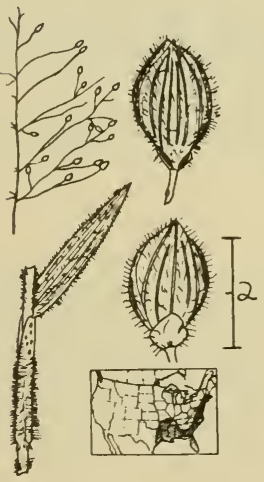

Figure 318

Perennial; tufted; plants $80-130 \mathrm{~cm}$. tall; leaf blades large, $12-20 \mathrm{~cm}$. long and $10-20 \mathrm{~mm}$. wide. The terminal panicles are open, elliptical, up to $15 \mathrm{~cm}$. long, produced in June and July. Later the plants become branched, with loose bunches of leaves in the axils of the sheaths of the main culm. The small secondary panicles are partially concealed among these branches. Low moist soil, mostly on the Atlantic Coastal Plain and northward in the Mississippi Valley.

36a. Spikelets over $3 \mathrm{~mm}$. long 
37a. Upper leat sheaths bristly hairy with spreading hairs; leaf blades 6-12 mm. wide. Fig. 319.

Panicum scribnerianum Nash

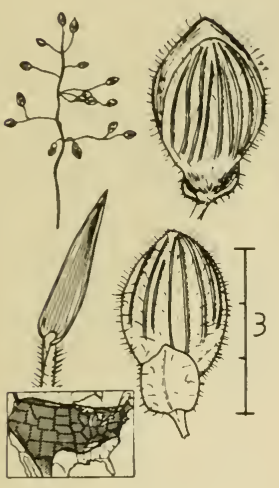

Perennial; tufted; plants $20-50 \mathrm{~cm}$. tall, rather stiff; sheaths sparsely covered with stiff spreading bristles or nearly smooth. The terminal panicles, produced in May and June, are 4-8 $\mathrm{cm}$. long and about as broad, pyramid-shaped. After the terminal panicles have shed their spikelets, the plants become bushybranched and produce small, simple panicles partially concealed by the tufted upper leaves. Prairies and open woods, often on dry sandy soil.

Figure 319

37b. Upper sheaths glabrous or softly hairy; larger leaf blades $1.5-4$ cm. wide. Fig. 320.

Panicum latifolium L.

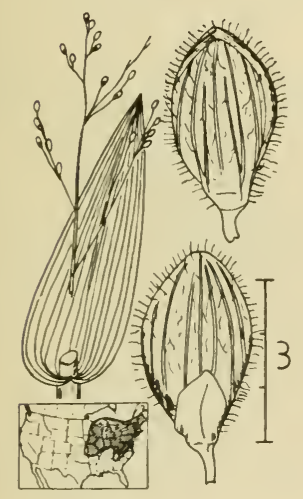

Figure 320

Perennial; tufted; $45-100 \mathrm{~cm}$. tall; terminal panicles produced in June, about $10 \mathrm{~cm}$. long and nearly as wide, with stiff spreading branches; spikelets hairy, $3.4-3.7 \mathrm{~mm}$. long. This is one of the most easily recognized of all grasses. The very broad leaf blades are heart-shaped at the base. Roadsides, woods, stream banks. The following species are also wide-leaved.

Panicum clandestinum L. has very bristly sheaths on the secondary branches. Spikelets $2.7-3 \mathrm{~mm}$. long.

Panicum boscii Poir. has spikelets over 4 $\mathrm{mm}$. long. The nodes of the stems are bearded with soft hairs, and the foliage is sometimes hairy.

38a. Culms glabrous

38b. Culms covered with short fuzz and sometimes with longer hairs. .40 
39a. Spikelets glabrous, narrowly elliptical, $1.8-2.2 \mathrm{~mm}$. long; leaf blades not hairy on the margins. Fig. 321 .

Panicum dichotomum L.

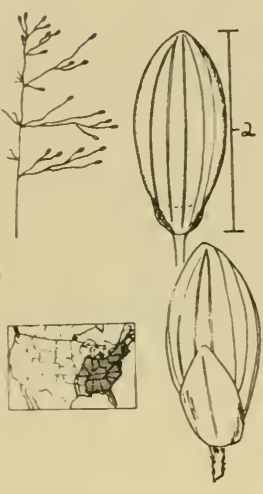

Figure 321

Perennial; tufted; plants erect, $30-50 \mathrm{~cm}$. tall, glabrous or with a ring of hairs on the lower nodes; terminal panicles in June, 4-9 $\mathrm{cm}$. long, with spreading branches. Later the culms become much branched from the middle nodes, appearing like little trees and sometimes falling from their weight. The secondary panicles are small, with few spikelets. They extend slightly above the leaves of the branches. Widespread and common in rocky woods and on brushy land.

Panicum microcarpon Muhl. has strongly bearded nodes and tiny spikelets, 1.5-1.7 $\mathrm{mm}$. long. Moist woods, meadows, and swamps.

39b. Spikelets minutely hairy, broadly obovoid at maturity, $1.5-1.8$ $\mathrm{mm}$. long: leaf blades 7-14 $\mathrm{mm}$. wide, with long marginal hairs at the base. Fig. 322 .

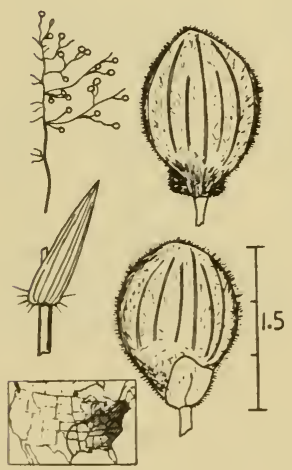

Figure 322

Panicum sphaerocarpon Ell.

Perennial; tufted; culms $20-55 \mathrm{~cm}$. long, erect or spreading; plants glabrous except for the few hairs at the base of each leaf blade, and often somewhat glaucous. Leaf blades rather broad, the top one $4-9 \mathrm{~mm}$. in width. The broad panicle is less than twice as long as wide. Dry open ground and thin woods. Terminal panicles in June and July.

Panicum polyanthes Schult. has a longer, elliptical panicle, 2-4 times longer than wide, and an uppermost leaf 9-28 $\mathrm{mm}$. wide. Open woods and damp ground. Southern New England to Oklahoma and southward. 
40a. Spikelets 2.2-2.7 $\mathrm{mm}$. long; leaf sheaths glabrous; culm internodes covered with short, bent hairs. Fig. 323 .

Panicum ashei Pearson

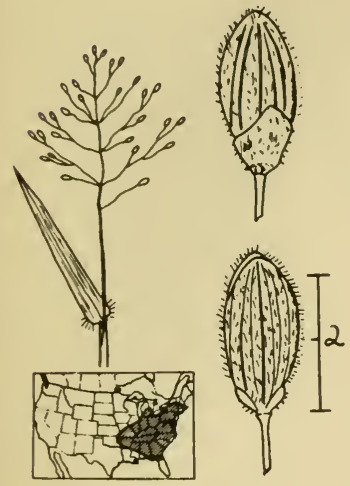

Figure 323
Perennial; tufted; plants stiffly erect, 25 $50 \mathrm{~cm}$. tall. The pyramid-shaped primary panicles are 5-8 $\mathrm{cm}$. long and have rather few spikelets. The internodes of the culms and portions of the leaf blades tend to be purple. The plants become rather sparingly branched, with elongated branches. Dry rocky woods, brushland, often on sandy ground. Primary panicles produced from May to July.

40b. Spikelets $1.5-1.9 \mathrm{~mm}$. long; leaf sheaths hairy; at least some of the sheaths and internodes covered with a mixture of long hairs and short, fine fuzz. Fig. 324.

Panicum columbianum Scribn.

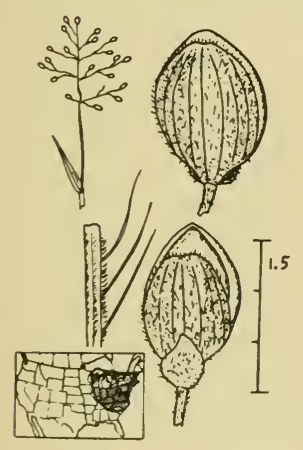

Figure 324

Perennial; tufted; plant $15-50 \mathrm{~cm}$. tall; leaf blades $3-6 \mathrm{~cm}$. long, $3-5 \mathrm{~mm}$. wide, the upper surface glabrous and the lower with fine, short hairs; primary panicles ovoid, $2-7$ $\mathrm{cm}$. long, produced in June and July. Later the plants become much-branched and bushy, often making mats on the ground. Dry sandy or rocky sterile ground, in the open or in thin woods.

Panicum meridionale Ashe. Plants small and delicate; leaf blades $1.5-3 \mathrm{~cm}$. long, 2-4 $\mathrm{mm}$. wide; upper surfaces of leaves bearing long, erect hairs; spikelets $1.3-1.5 \mathrm{~mm}$. long. Sterile soil; N. S. to Minn., Ga., and Ala.

4la. Spikelets glabrous or hairy, never warty ............42 
41 b. Spikelets glabrous, covered with minute warts. Fig. 325 .

Panicum verrucosum Muhl.

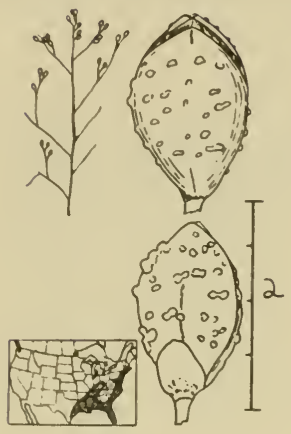

Figure 325

Annual; plants sprawling, the culms branching and rooting from the lower nodes, up to $150 \mathrm{~cm}$. long. The entire herbage is glabrous except for the margins of the sheaths; leaf blades thin, bright green, $5-20 \mathrm{~cm}$. long, 4-10 $\mathrm{mm}$. wide; ligules very short, hairy; panicles up to $30 \mathrm{~cm}$. long, very open, the small (about $2 \mathrm{~mm}$. long) spikelets borne in groups of $1-3$ near the ends of the branches. Banks of streams; moist sandy or peaty soil. July-September.

Panicum brachyanthum Steud. has narrower leaf blades, $2-3 \mathrm{~mm}$. wide; pointed spikelets $3.2-3.6 \mathrm{~mm}$. long, covered with wart-based hairs. August-September. Arkansas and Oklahoma to Louisiana and Texas.

42a. Fertile lemma minutely cross-wrinkled. Fig. 326.

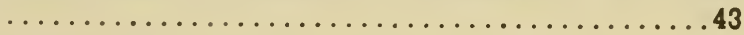

42b. Fertile lemma smooth and shining.........44

43a. Spikelets 5-6 mm. long, hairy. Fig. 327. TEXAS MILLET; COLORADO GRASS

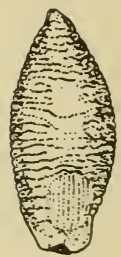

Figure 326

Panicum texanum Buckl.

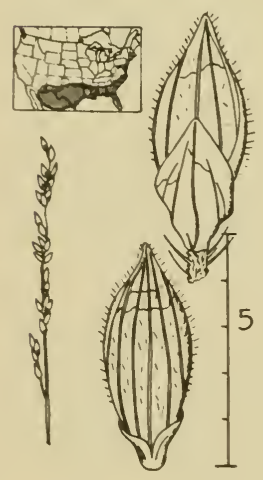

Figure 327

Annual; culms hairy, erect or decumbent and rooting at the lower nodes, usually $50-150 \mathrm{~cm}$. long; leaves 7-16 mm. wide, $10-20 \mathrm{~cm}$. long, softly velvety; leaf sheaths velvety; ligule hairy, about $1 \mathrm{~mm}$. long; panicles narrowly cylindrical, 7-25 cm. long, up to $3 \mathrm{~cm}$. in diameter; rachis and branches hairy. The lush, vigorous plants make good forage. They occur along streams and in corn and cotton fields. The common name, Colorado Grass, apparently refers to the Colorado River of Texas, since this species does not occur in the state of Colorado. JuneSeptember.

Panicum arizonicum Scribn. and Merr. has similar spikelets, $3.5-3.8 \mathrm{~mm}$. long; blades 6$12 \mathrm{~mm}$. wide; panicle more open, with hairy branches. Western Texas to California and Mexico. August-September. 
43b. Spikelets 2-4 mm. long, glabrous. Fig. 328 .

BROWNTOP MILLET

Panicum fasciculatum Swartz

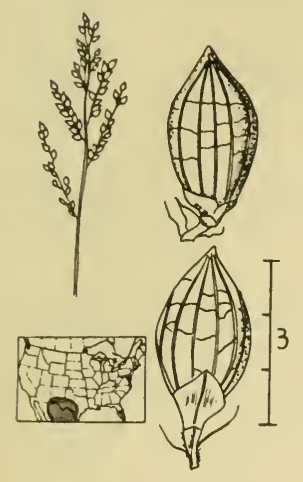

Figure 328

Annual; tufted, rather bushy; culms 30-100 $\mathrm{cm}$. long; leaf blades $6-20 \mathrm{~mm}$. wide, glabrous; ligule of hairs, $1 \mathrm{~mm}$. long; sheaths glabrous or papillose-hairy; panicles 5-15 $\mathrm{cm}$. long, made up of simple branches 5-10 $\mathrm{cm}$. long, the spikelets nearly sessile on the branches; spikelets frequently yellowish or brown, 2-3 $\mathrm{mm}$. long, with pronounced crossveins between the longitudinal ones.

Var reticulatum (Torr.) Beal has pubescent leaf blades, 6-10 mm. wide; spikelets $2.6-$ $3.2 \mathrm{~mm}$. long.

These plants are common weeds in fields, on river flats, and on waste ground. MaySeptember.

44a. Plants without stolons; first glume much shorter than the whole

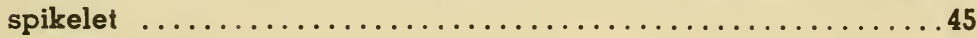

44b. Plants producing long, wiry stolons; spikelets very blunt, the first glume nearly as long as the spikelet. Fig. 329.

VINE MESQUITE GRASS

Panicum obtusum H. B. K.

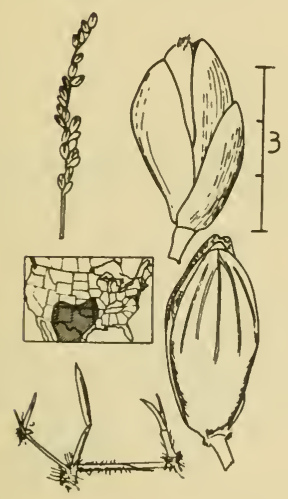

Figure 329

Perennial; producing elongated stolons up to $3 \mathrm{~m}$. or more in length, their nodes hairy, swollen; culms erect, flattened, $20-80 \mathrm{~cm}$. tall, with glabrous nodes; leaf blades 2-7 $\mathrm{mm}$. wide, glabrous; ligules $1 \mathrm{~mm}$. long, membranous; panicles $3-12 \mathrm{~cm}$. long, very narrow, with a few ascending branches; spikelets crowded, 3-3.8 $\mathrm{mm}$. long, glabrous, brownish; sterile lemma containing a palea and a staminate flower. Banks of streams, ditches, dry wash 2 , irrigated fields. Vine mesquite furnishes some grazing, especially in the spring. It is sometimes planted for erosion control, especially on terrace outlet channels, spillways of earth dams, and flood plain flats. June-September. 
45a. Plants producing underground spikelets on root-like underground branches; aerial panicles sterile. Fig. 330

45b. Plants lacking underground spikelets; panicles fer-

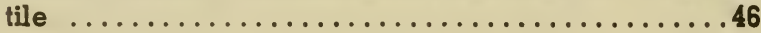

46a. Panicles with spreading or drooping branches; rhizomes present or absent.

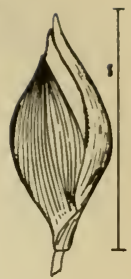

Figure 330

46b. Panicles long and slender, with erect branches; plants producing extensive rhizomes. Fig. 331 . MAIDEN CANE

Panicum hemitomon Schult.

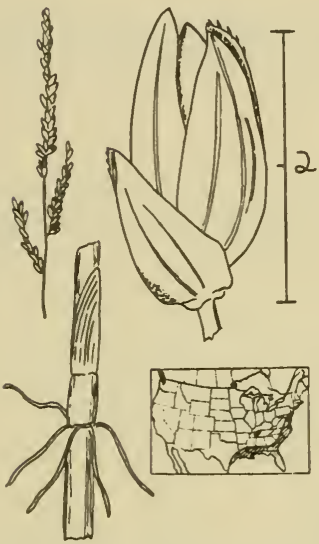

Perennial; culms hard and stiff, 50-150 $\mathrm{cm}$. tall; sheaths smooth or bristly; leaf blades 10-25 cm. long, 7-15 mm. wide, scabrous on top; panicles slender and spikelike, 15-30 cm. long; spikelets $2.3-$ $2.7 \mathrm{~mm}$. long. Wet ground and in water; ponds and ditches, wet fields, on the Atlantic and Gulf Coastal Plains. Sometimes maiden cane becomes $a$ weed in wet fields. April-July.

Figure 331

47a. Panicle much-branched, open, the spikelets usually on long stalks, not confined to the lower sides of the branches; fertile lemma not

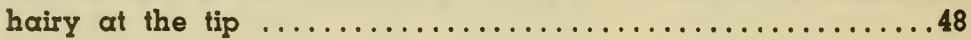

47b. Panicle with mostly unbranched main branches, the spikelets on short stalks, mostly on the lower sides of the branches; fertile lemma with a tuft of minute stiff hairs at the tip...........51

48a. Sheaths covered with stiff spreading hairs.............49

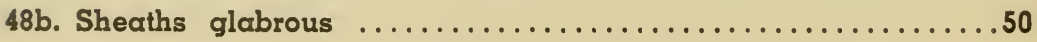


49a. Spikelets $3.5 \mathrm{~mm}$. long or shorter; panicle branches slender, stiff. Fig. 332.

WITCH GRASS

Panicum capillare L.

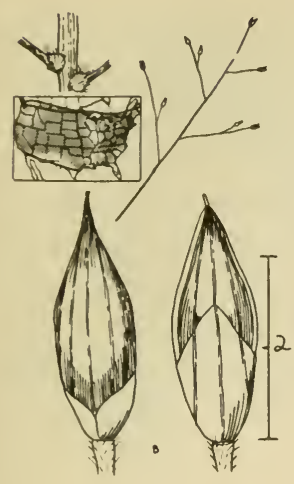

Figure 332

Annual; tufted; becoming bushy-branched, often a meter or more tall; foliage soft; leaf blades hairy on both surfaces, 5-15 $\mathrm{mm}$. wide; terminal panicles large, dome-shaped, often more than half the length of the plant; numerous axillary panicles also present; bases of panicles usually hidden in the sheaths; axils of main panicle branches bearing tufts of hairs; panicles at maturity breaking away from the plant and rolling away as tumbleweeds. This is one of the commonest weedy grasses of fields and disturbed soil; widespread in the United States. About eight similar species are found in various parts of the country, but are much less common. July -October.

49b. Spikelets $4.5 \mathrm{~mm}$. or more long; panicle branches stout, drooping. Fig. 333.

\section{BROOMCORN MILLET; PROSO MILLET}

Panicum miliaceum L.

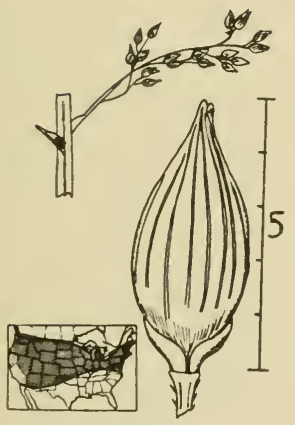

Figure 333

Annual; tufted; plants $20-100 \mathrm{~cm}$. tall; foliage coarsely hairy or nearly smooth; leaf blades up to $30 \mathrm{~cm}$. long and $20 \mathrm{~mm}$. wide; panicles $10-30 \mathrm{~cm}$. long, drooping, the branches scabrous; spikelets $4.5-5 \mathrm{~mm}$. long, plump; fertile lemmas yellow, reddish, or brown. Proso is grown sparingly in the United States for forage, hog feed, and bird seed. The plants occur as strays on waste ground. Proso is probably native to Asia. It is cultivated in the Orient, and to a lesser extent in Europe. It is supposed to be one of the most ancient of cultivated crops, and was known to the Romans under the name of Milium, whence comes our word millet. July-September. 
$50 a$. First glume rounded or broadly triangular, $1 / 4-1 / 3$ as long as the spikelet; plants annual, without rhizomes. Fig. 334.

FALL PANICUM

Panicum dichotomitlorum Michx.

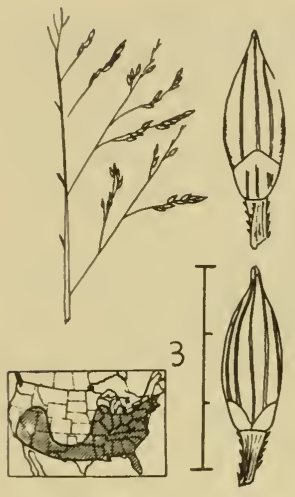

Annual; tufted; plants bushy, with freely branching erect or spreading culms; often coarse, with culms up to $2 \mathrm{~m}$. long in vigorous specimens; stems often zig-zag, with an axillary panicle at each upper node. This is a common weed of cultivated fields, waste ground and moist soil around ponds or along streams. The size of the plants varies greatly, depending upon the moisture and fertility of the soil. July-October.

Figure 334

50b. First glume at least half the length of the spikelet, tapering to a sharp point; plants perennial, with hard, rhizome-producing bases. Fig. 335.

SWITCH GRASS

Panicum virgatum L.

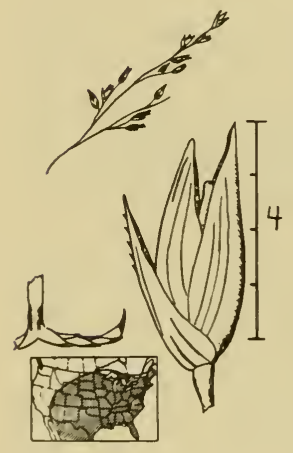

Figure 335

Perennial; in clumps, spreading by thick scaly rhizomes; culms strong, $1-2 \mathrm{~m}$. tall; panicles large and open, $15-50 \mathrm{~cm}$. long; spikelets 3.5 $-5 \mathrm{~mm}$. long, often reddish in color and at times appearing laterally compressed. Switch grass is one of the most important native grasses of the tall grass prairie, but occurs far beyond the prairie area as well. Prairies, open ground, river banks and bottomlands, thin woods. $A$ valuable forage species, sometimes harvested as a part of wild prairie hay. July-October. 
5la. Plants producing rhizomes; spikelets scythe-shaped, set at an angle to the pedicel. Fig. 336 .

Panicum anceps Michx.

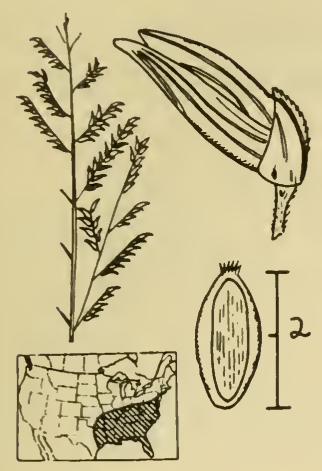

Figure 336

Perennial; short scaly rhizomes present; culms erect, $50-100 \mathrm{~cm}$. tall; leaves smooth or hairy, elongated, 4-12 mm. wide; panicles open, 15-40 cm. long; spikelets $3.4-$ $3.8 \mathrm{~mm}$. long, curved. Open moist ground and woods, especially on sandy soil. July - September.

Panicum rhizomatum $\mathrm{H}$. \& $\mathrm{C}$. is similar but has more elongated rhizomes, contract. ed panicles, and spikelets $2.4-2.8 \mathrm{~mm}$. long. Sandy soil on the Atlantic and Gulf Coastal Plains, Maryland to Texas; Tennessee.

51b. Plants without rhizomes; spikelets straight or nearly so, set in line with the pedicel. Fig. 337.

Panicum agrostoides Spreng.

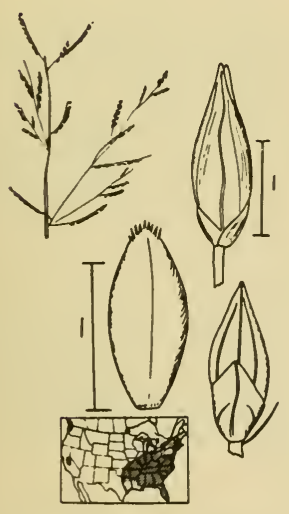

Perennial; tufted; culms $50-100 \mathrm{~cm}$. tall; panicles elliptical, the branches densely clustered with nearly sessile spikelets; spikelets green or somewhat reddish, $1.8-2.2 \mathrm{~mm}$. long. Moist shores and meadows, swamps, alluvial mud flats. July-September.

Panicum condensum Nash is similar but has a denser panicle; spikelets $2.2-2.5 \mathrm{~mm}$. long. Wet ground on the Coastal Plains, Pennsylvania to Florida and Texas. 


\section{TRIBE XII. ANDROPOGONEAE}

la. Both spikelets of each pair on stalks........................

1b. One spikelet of each pair sessile.................

2a. Racemes single on each peduncle; awns hairy...........lb

2b. Racemes several to many on each peduncle; awns absent or

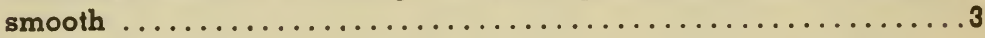

3a. Inflorescence narrow, spikelike; spikelets awnless. Fig. 338.

SATINTAIL

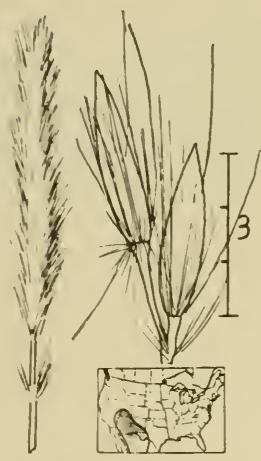

Figure 338

Imperata brevifolia Vasey

Perennial; culms arising from hard scaly rhizomes; culms $1-1.5 \mathrm{~m}$. tall, with elongated leaves and slender, silvery-hairy panicles, 15 $-35 \mathrm{~cm}$. long and $1-3 \mathrm{~cm}$. thick. The spikelets are about $3 \mathrm{~mm}$. long and have a ring of long white hairs at the base, with some hairs also attached to the backs of the glumes. The spikelets fall from the rachis when ripe. Deserts. July-September.

Imperata cylindrica (L.) Beauv. (COGON GRASS) has been introduced in western Florida. Spikelets $4-5 \mathrm{~mm}$. long. This species has forage uses but may become a weed, because of its extensive rhizomes.

3b. Inflorescence fan-shaped; spikelets with awns. Fig. 339. EULALIA

Miscanthus sinensis Anderss.

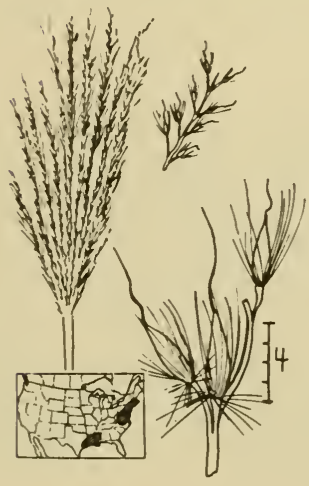

Figure 339

Perennial, forming large clumps; culms 2-3 m. tall, with plumelike, silvery-gray, fan-shaped panicles of long, hairy racemes. The spikelets are about $5 \mathrm{~mm}$. long, with a ring of hairs about as long as the spikelet, attached at the base of the glumes. The spikelets fall from the rachis when ripe. Cultivated widely as an ornamental, and escaping to the wild occasionally around inhabited places. Horticultural forms with white striped or cross-banded leaves are also grown. September-October. Native to Asia. 
4a. Each raceme* of spikelets consisting of many pairs of spikelets; racemes solitary or variously grouped.................

4b. Each raceme consisting of $1-3$ pairs of spikelets; racemes grouped into an open or dense panicle...................... 15

5a. Both spikelets of each pair alike and with perfect florets.....6

5b. One spikelet of each pair perfect, the other either staminate, sterile, reduced in size, of a different shape, or nearly absent.......7

6a. Spikelets with awns; wild plants. Fig. 340.

SILVER PLUMEGRASS

Erianthus alopecuroides (L.) Ell.

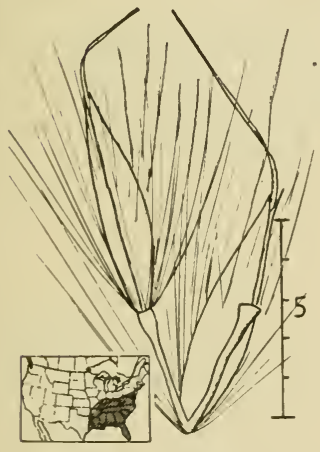

Figure 340

Perennial; culms strong and tall, $1-3$ m. long, arising from short, scaly rhizomes. The nodes, upper portions of the sheaths, and peduncles are appressed-hairy. The dense silky-hairy elliptical panicles are 20 $-30 \mathrm{~cm}$. long. Each yellowish spikelet bears a tuft of long silvery or purplish hairs from the base, as well as a few hairs on the upper portions of the glumes. Spikelets 5-6 mm. long, with a flattened and twisted awn $1-1.5 \mathrm{~cm}$. long. The rachis breaks up into individual joints when ripe. Open woods, wet low ground, hammocks. September-October.

Erianthus contortus Ell. is similar, but has dark brown glumes.

Erianthus giganteus (Walt.) Muhl. (E. saccharoides) is similar but has straight, untwisted awns which are not flattened in crosss section.

*According to strict definition, these inflorescence branches are not racemes, because they have some sessile spikelets, but this term is usually used. 
6b. Spikelets without awns; cultivated plants. Fig. 341 .

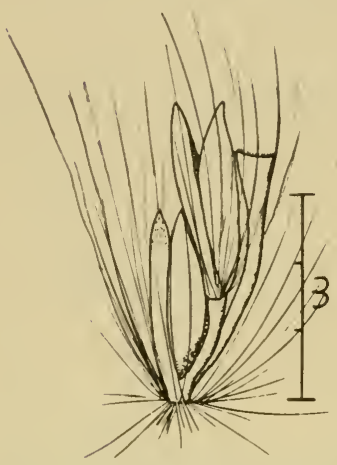

Figure 341

Perennial; tall stout plants, with culms $3-5 \mathrm{~m}$. tall and up to $3 \mathrm{~cm}$. thick. The stiff, elongated leaves have very scabrous cutting edges. Panicles large and plumelike, 20-60 cm. long. The racemes break up into individual joints when ripe, with a pair of spikelets attached to each joint. Sugar cane is widely cultivated in the tropics for the production of sugar, but in the United States is grown only in the southern end of the Mississippi Valley and in Florida. The plants seldom bloom.

Erianthus ravennae (L.) Beauv. (RAVENNA GRASS) has a large, plumelike panicle, up to $60 \mathrm{~cm}$. long, and slender culms up to $4 \mathrm{~m}$. tall. Cultivated for ornament and hardy in the southern half of the country. 7a. Pedicels and rachis joints thickened at the upper ends, closely pressed together or united; spikelets awnless.............. 8

7b. Pedicels and rachis joints not evidently thickened, not pressed together nor united; spikelets awnless or awned.............9

$8 \alpha$. Perfect spikelet spherical, with $\alpha$ rough pitted surface; rachis joint and pedicel united. Fig. 342 .

Hackelochloa granularis (L.) Kuntze

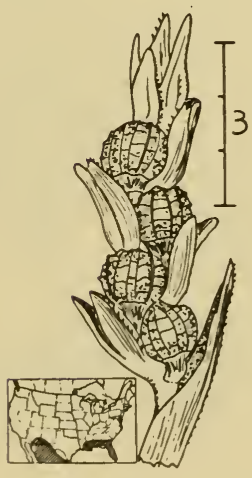

Figure 342

Annual; tufted; culms $30-100 \mathrm{~cm}$. tall, much branched. The culms have numerous axillary racemes; sheaths and culms covered with hairs which arise from little blisters. The spikelets are borne in spikes or racemes, $1-2 \mathrm{~cm}$. long, the individual spikelets being $1-2 \mathrm{~mm}$. long. The racemes break up into individual joints, each bearing a sessile perfect spikelet which is blackish, and a strongly laterally compressed and winged staminate spikelet, which is green or reddish in color. This unusual grass is a native of the Old World tropics, but has been introduced into our southern states. It may yield some forage. Fall. 
8b. Perfect spikelet lanceolate, smooth or rough; rachis joint and pedicel separate. Fig. 343.

Manisurus rugosa (Nutt.) Kuntze

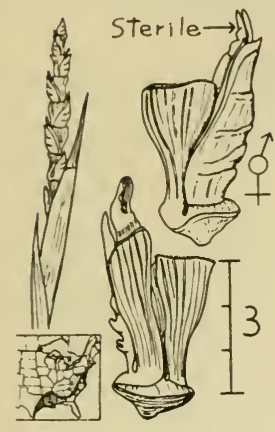

Figure 343

Perennial; culms from hard, knotty crowns; culms flattened, much branched, $70-120 \mathrm{~cm}$. tall, with numerous axillary racemes. Racemes slender, "rat-tail"-like, brownish, 4-8 $\mathrm{cm}$. long, tapering from the middle toward the base and apex. They break up into individual joints readily, each joint bearing $\alpha$ perfect sessile spikelet and a sterile spikelet on a thickened pedicel. The first glume of the spikelet is strongly corrugated across the width. Wet pine woods and bogs, Atlantic and Gulf Coastal Plains. September. Four other similar species are found in the southern states, differing in the degree of roughness, pitting, etc. of the first glume.

9a. One raceme on each peduncle................... 10

9b. Several to many racemes on each peduncle.............12

10a. Awns hairy, stiff and strong, 3-12 cm. long; awned spikelets bearing $\alpha$ sharp hairy callus at the base................11

10b. Awns not hairy, thin and delicate, $2 \mathrm{~cm}$. long or shorter; spikelets disarticulating at the base of the glumes............

11a. One awned and one awnless spikelet falling as a pair; rachis of the raceme disarticulating. Fig. 344.

TANGLEHEAD

Heteropogon contortus (L.) Beauv.

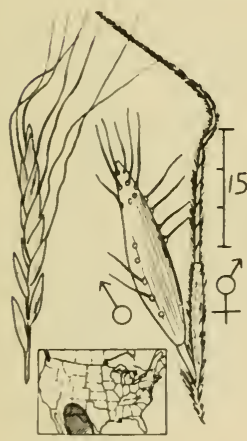

Figure 344

Perennial; tufted; plants $20-80 \mathrm{~cm}$. tall; leaf sheaths flattened and keeled; racemes borne at the tips of slender peduncles. The pairs of spikelets at the base of each raceme are all staminate. In the upper portion of the raceme, each pair consists of a sessile perfect spikelet and a stalked staminate spikelet. The sessile spikelet has a long, bent awn and a hairy rachis joint, which is attached below the base of the glumes. This spikelet greatly resembles the floret of some species of Stipa. Attached at the base of the perfect spikelet is a short pedicel bearing an awnless, laterally compressed and winged staminate spikelet. The two spikelets of each pair fall as a unit. Because of the sharp hairy callus and stiff awn, the perfect spikelets may injure grazing sheep. A good forage grass when not in fruit. Rocky deserts in 
the Southwest; found throughout the tropics of both Old and New World. June-September.

Heteropogon melanocarpus (Ell.) Benth. has staminate spikelets with glabrous glumes, a row of glandular spots running down the middle of the glume. Southeastern states and Arizona.

11b. Awned spikelets falling, awnless ones remaining on the persistent rachis of the raceme. Fig. 345.

CRINRLE AWN

Trachypogon secundus (Presl) Scribn.

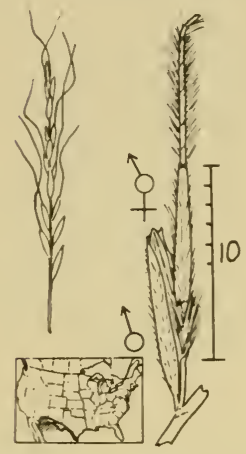

Figure 345

Perennial; tufted; $60-120 \mathrm{~cm}$. tall; herbage nearly smooth but the nodes bearing a circle of stiff, erect hairs. The erect slender raceme is $10-20 \mathrm{~cm}$. long. The rachis remains whole with the short-pedicellate or sessile staminate spikelets attached to it. The longer-pedicellate perfect spikelets break from the rachis with their hairy, rigid pedicels attached. The perfect spikelet looks very much like the floret of some species of Stipa. The lemma is $6-8 \mathrm{~mm}$. long, with a bent and twisted awn $3-6 \mathrm{~cm}$. long. Rocky dry hills. May-October.

12a. Racemes several to many on each peduncle.............

12b. Racemes one on each peduncle. Fig. 346. LITTLE BLUESTEM

Andropogon scoparius Michx.

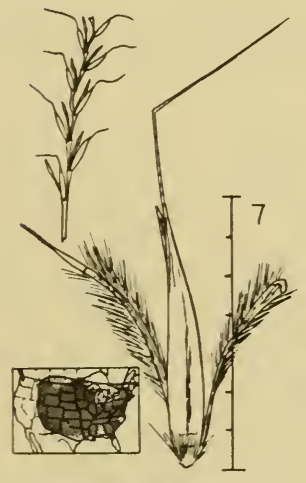

Figure 346

Perennial; tufted; plants green or reddish, $50-150 \mathrm{~cm}$. tall; foliage smooth or hairy. The racemes are borne on slender peduncles from the axils of the sheaths and the tips of the culms. The rachis joints and pedicels are strongly hairy. Little bluestem is characteristically a plant of dry prairies and plains, but occurs to some extent over nearly the entire United States. Prairies, old fields, rocky slopes and open woods. Little bluestem furnishes much grazing in the Middle West and West, especially for cattle and horses. August-October.

Nine other species, similar in having only one raceme on each peduncle, occur in the southern United States, but are much rarer.

13a. Stalked spikelet sterile, reduced to a small rudiment or nearly absent; racemes feathery, white................... 
13b. Stalked spikelet staminate, similar to the sessile one but awnless; racemes green or purplish in color, not feathery with fine hairs. Fig. 347.

BIG BLUESTEM

Andropogon gerardi Vitman

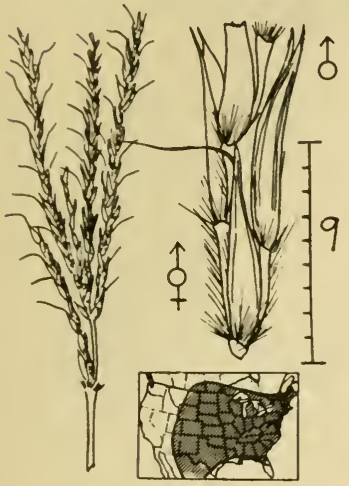

Figure 347

Perennial; tufted or with short rhizomes; plants green or reddish, $1-2 \mathrm{~m}$. tall or even taller; foliage sometimes hairy. The plants bear $3-6$ reddish racemes at the tip of the culm, and usually some smaller inflorescences from the axils of the leaves. Big bluestem was one of the principal grasses of the tall grass prairie which produced the rich soils of our corn belt. Very little of such grassland still exists, but this species is still very common on untilled land in the prairie area. Farther east it is less common, but occurs on steep slopes, in meadows, and along river banks. This is an important forage species, and still provides much wild hay from native prairie. August -October. Also known as $A$. furcatus and $A$. provincialis.

Andropogon hallii Hack. (SAND BLUESTEM) has more elongated rhizomes and yellowish spikelets. Sandhills of the Great Plains and Rocky Mountain area.

14a. Inflorescence of two to four racemes, which are inclosed at their bases by a leaf sheath. Fig. 348.

BROOMSEDGE

Andropogon virginicus L.

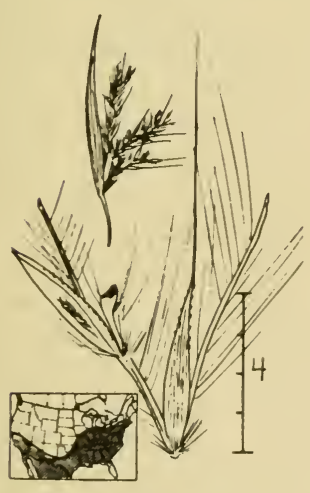

Figure 348

Perennial; tufted; $50-100 \mathrm{~cm}$. tall; foliage smooth or somewhat hairy, often reddish; culms bearing feathery-hairy inflorescences at the tip and from the axils of the leaves of the upper half of the culm. Broomsedge is a plant of sterile open hillsides, abandoned fields, and thin woods. It usually indicates poor soil. The forage value is apparently low, especially when the plants are mature. August-October.

About fourteen other similar species or varieties occur in the southeastern states, mostly on the coastal plain. Most striking of these is the following.

Andropogon glomeratus (Walt.) B. S. P. (A. virginicus, var. abbreviatus (Hack.) Fern.). All the inflorescences are condensed into a dense, broom-like 
cluster at the top of the stem. Southeastern states; Texas to California, often on damp, low ground.

14b. Inflorescence a terminal panicle of numerous racemes; leafy bracts absent from the panicle. Fig. 349.

SILVER BEARDGRASS

Andropogon saccharoides Sw.

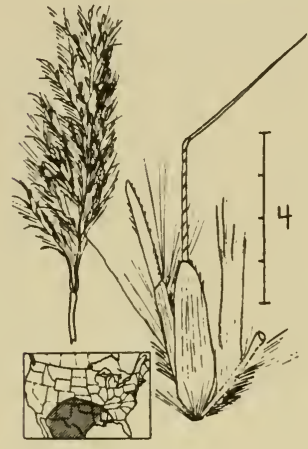

Figure 349

Perennial; tufted; rather bushy; culms $60-130 \mathrm{~cm}$. tall; foliage usually glabrous, becoming reddish when mature. The longstalked panicles are silvery white, oblong, 7-15 cm. long. The rachis joints and pedicels are fringed with long white hairs. Sessile spikelet of each pair about $4 \mathrm{~mm}$. long, the pedicellate one rudimentary. Silver beardgrass and several of its close relatives are valuable forage grasses in parts of the Southwest, but are easily exterminated by overgrazing. Prairies and plains, rocky slopes, draws and dry washes, often on sandy soil. June-September.

Andropogon perforatus Trin. has a small "pinhole" pit in the center of the first glume. Texas and Mexico.

Andropogon barbinodis Lag. is taller, with a short, fan-shaped panicle, with spikelets $5-6 \mathrm{~mm}$. long. The nodes of the culms are prominently bearded. Oklahoma to California and Mexico.

15a. Stalked spikelets present, staminate.................

15b. Stalked spikelets lacking, only the hairy pedicel present. Fig. 350. INDIAN GRASS

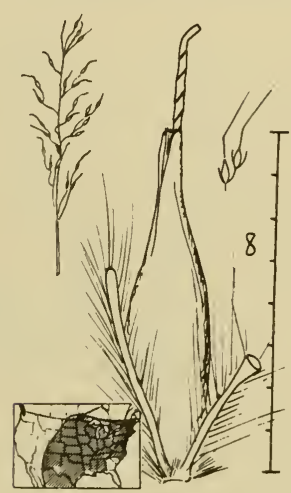

Figure 350

Sorghastrum nutans (L.) Nash

Perennial; in tufts from short rhizomes; plants $1-2.5 \mathrm{~m}$. tall; foliage usually smooth. Panicles narrow and rather dense, 15-30 cm. long. The panicle has a "goldand-silver" aspect because of the yellow, 5-6 $\mathrm{mm}$. long spikelets and the copious white hairs which fringe the rachises and pedicels. The prominent anthers are golden yellow. The panicle is made up of short racemes of $1-3$ joints. Each sessile spikelet is accompanied by $\alpha$ hairy pedicel. The racemes break up into individual joints at maturity, each bearing a spikelet and a rachis joint and pedicel. Indian grass is one of the principal grasses of the tall grass prairie. It is also found in the eastern states and the Rocky Mountains. It forms an important component of wild prairie hay. Prairies, plains, stream banks, dry hills. July-September. 
16a. Spikelets when ripe disarticulating from the tip of the pedicel; end of pedicel cup-shaped; rhizomes present; weed. Fig. 351.

JOHNSON GRASS

Sorghum halepense (L.) Pers.

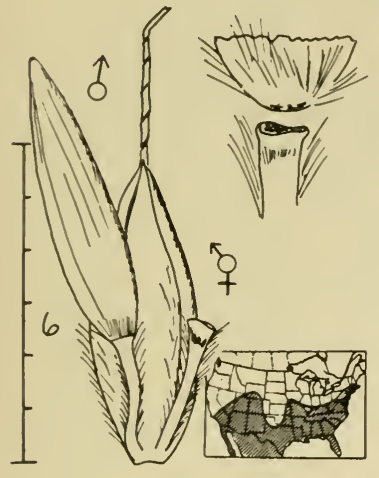

Figure 351

Perennial; culms tall and stout, $0.5-$ $2 \mathrm{~m}$. tall, arising from thick, widelyspreading rhizomes; panicle open, pyramid-shaped, $15-50 \mathrm{~cm}$. long. The sessile spikelet is perfect and fertile, hard, and rather plump, about $5 \mathrm{~mm}$. long. The awn falls off readily, so the spikelets are often awnless. The pedicellate spikelets are of softer texture, staminate, narrower, and awnless. The sessile spikelet at the end of each short raceme is accompanied by two pedicellate spikelets. The fertile spikelets vary from straw-colored to almost black. This species, regarded as a noxious weed in the southern states, is very similar to the annual crop, Sudan grass. Despite its bad traits, Johnson grass furnishes a great deal of forage and is readily eaten by livestock. Eurasian.

16b. Spikelets when ripe breaking from the plant with the upper end of the pedicel, leaving a jagged stub; rhizomes lacking; crop plant. Fig. 352.

SUDAN GRASS

Sorghum sudanense (Piper) Stapf

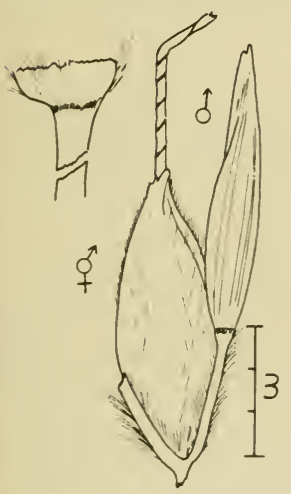

Figure 352

Annual; tufted; culms $1-3 \mathrm{~m}$. tall. The plants resemble those of Johnson grass but lack the rhizomes. Widely cultivated for annual pasture and hay and sometimes found as a stray from dropped seed. Native to North Africa.

Sorghum vulgare Pers. (SORGHUM) This species includes a large group of rather cornlike plants, cultivated in warm sections of the country for grain, fodder, silage, and syrup. The leaves and stems greatly resemble Indiom corn, but the spikelets, similar to those of Johnson grass, are all borne in panicles at the tips of the stems. The grains may be black, brown, reddish, gray, or white. In many varieties, the grain becomes large enough to burst out of the glumes. Milo, hegari, feterita, durra, kafir corn, shallu, amber cane, broomcorn, etc. are all varieties of this species. Broomcorn is not used for forage, but the stiff, elongated panicle branches are the broomstraw of commerce. 


\section{TRIBE XIII. TRIPSACEAE}

1a. Pistillate spikelets borne in hard, bony beads, each bead on a separate stalk; staminate spikelets protruding on a stalk from the opening of the bead. Fig. 353.

JOB'S TEARS

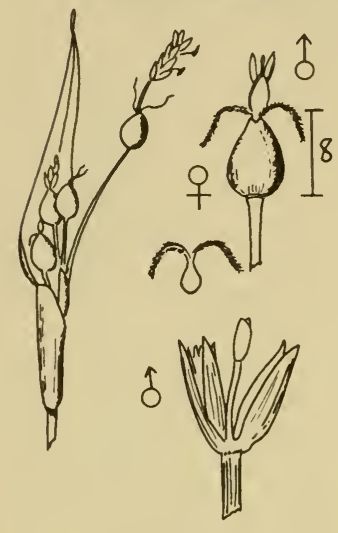

Figure 353

Coix lacryma-jobi L.

Annual; plants coarse, somewhat cornlike, up to $1 \mathrm{~m}$. tall, abundantly branching from the upper nodes. Each peduncle bears a hard, shiny, white, grayish, or black bead, from the upper end of which protrudes a short inflorescence consisting of few joints bearing sessile and pedicellate staminate or sterile spikelets, in somewhat irregular combinations. Staminate spikelets consist of 2 glumes, inclosing 2 staminate florets. Within the bead is borne a single pistillate spikelet and 2 slender, tubular, sterile spikelets, along with the stalk of the staminate inflorescence. The stigmas protrude from the mouth of the bead. The staminate inflorescence breaks away and the beads fall from the plant when ripe. Job's tears is cultivated as a curiosity, and for the "beads," which are used in rosaries and jewelry. The plants may be found in the wild in the southern states. Introduced from the tropics of the Old World. Late summer.

lb. Pistillate spikelets borne in spikes or on cobs, never separately..2

2a. Staminate spikelets borne at the tip and pistillate spikelets at the base of the same spike; pistillate portion of the spike hard and bony; husks not present. Fig. 354 .

GAMA GRASS

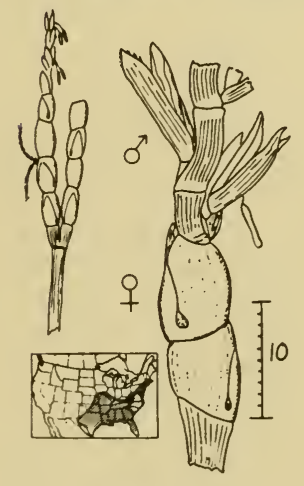

Figure 354

Tripsacum dactyloides $\mathrm{L}$.

Perennial; in large clumps, from thick rhizomes. The plants reach $2-3 \mathrm{~m}$. in height. The spikes are borne singly or $2-3$ together at the tips of long leafless peduncles. The basal portion of each spike consists of a series of hardened, smooth, hollowed-out joints, each nearly inclosing a single pistillate spikelet. These joints break apart readily when ripe. The upper portion of each spike is made up of a series of joints, each bearing 2 sessile staminate spikelets. This portion of the spike is shed whole when the pistillate rachis breaks up. Gama grass is a close relative of corn and has been experimentally crossed with it. The plants are leafy and may produce some forage, but they are sel-

dom abundant. River banks and moist ground. June-October. 
2b. Staminate spikelets in a "tassel" at the stem tips; pistillate spikelets on a many-rowed axillary "cob," surrounded by leafy husks. Fig. 355.

MAIZE; INDIAN CORN

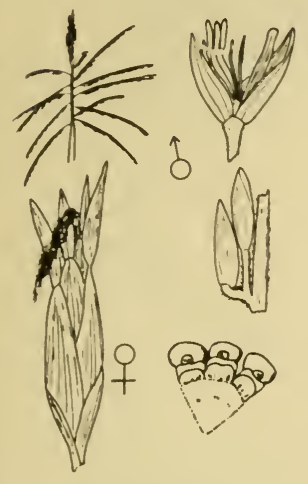

Figure 355

Annual; tufted; plants exceedingly variable in size and habit, but characteristically with thick, solid stalks. The pistillate inflorescence (ear) has paired rows of spikelets. The glumes, sterile and fertile lemmas form the "chaff" that remains on the cob. In a few varieties, such as Country Gentlemen, both florets of each pistillate spikelet develop grains, producing very crowded and ir-

regular rows. Corn is unusual in having united styles, which form the "silk." The staminate inflorescence (tassel), is much-branched and bears pairs of spikelets, one of each pair being sessile and the other pedicellate. Because of the great crowding of the staminate spikelets, the arrangement may be obscured. The staminate spikelets are each two-flowered.

Corn never persists after cultivation and is unknown in the wild state. It is suspected that it originated in Central America.

Euchlaena mexicana Schrad. (TEOSINTE) is intermediate between corn and Tripsacum in structure. The staminate spikelets are borne in a terminal tassel, like those of corn, and the general appearance of the plants is like that of corn. The pistillate spikelets are borne in single spikes of hardened joints, like those of Tripsacum. These spikes break up into l-spikelet segments when ripe. They are hidden, however, in husks like those of the corn ear. Teosinte is sometimes cultivated as a forage plant in the South and occurs as a weed in the American tropics. It is closely related to corn and hybridizes with it.

Zea mays L.

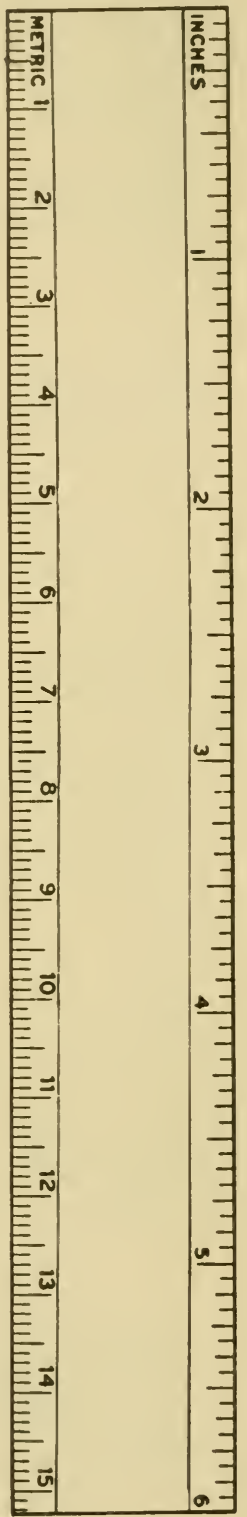

Figure 356 


\section{INDEX AND PICTURED-GLOSSARY}

\section{A}

Aegilops 85 cylindrica 85 triuncialis 85

Agropyron 87 cristatum 88 desertorum 88 pauciflorum 89 repens 88 smithii 87 spicatum 89 subsecundum 89 trachycoulum 89

Agrostideae 11, 19, 21, 102

Agrostis 116

albo 117

exarata 118

humilis 117

hyemalis 118

oregonensis 119

palustris 116

perennans 119

scabro 118

tenuis 116

variabilis 117

Aira 97 coryophyllea 97

Alkali cordgrass 136

Alkali grass 58

Alkali sacaton 128

Alopecurus 103 aequalis 104 protensis 103

Alpine timothy 112

American beachgrass 112

Ammophila 112 breviligulata 112

Amphicorpum 164 muhlenbergianum 164 purshii 164

Andropogon 180 barbinodis 182

furcatus 181

gerardi 181

glomeratus 181

hallii 181

perforatus 182

provincialis 181

saccharoides 182

scoparius 180

virginicus 181

Andropogoneae 12, 20, 21 . 176

Annual bluegrass 82

Annual ryegrass 86

Anthoxanthum 145 odoratum 145

APEX: the tip of a leaf. 4 Fig. 356

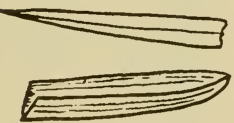

Figure 356
Aristida 26, 106 basiramea 106 var. curtissii 106

dichotoma 106

fendleriana 107

longiseta 107

oligantho 107

Arizona fescue 73,74

Arrhenatherum 22, 96 elatius 22, 96

Arundinario 15 gigantea 15 tecta 15

Arundo 24 donax 24

Astoria bent 116

AURICLES: small pointed or rounded projections at the base of the blade, 4 .

Fig. 357
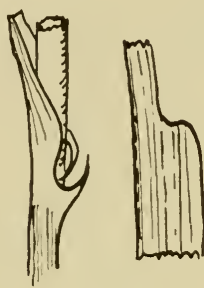

Figure 357

Avena 99

fatuo 99

sativa 99

Aveneae 10, 22, 95

AWN: a protruding midrib of a glume or lemma, forming a beard or bristle. Lateral nerves rarely produce awns, 6. Fig. 358
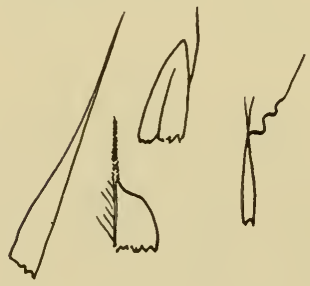

Figure 358

Axonopus 159
offinis 159

8

Bambuseae 10, 15

Barley 90
Barnyard grass 156

Beckmannia 135 syzigachne 135

Bermuda grass 135

Big bluestem 181

Big galleta 130

Black gramo 142

BLADE: the elongated spreading portion of grass leaf. 4 Fig. 359

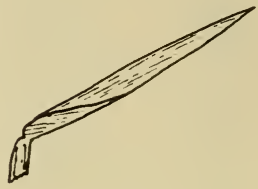

Figure 359

Blepharoneuron 126 tricholepis 126

Blowout grass 28

Eluebunch fescue 74

Bluebunch wheatgrass 89

Blue grama 131, 143

Bluejoint 114

Bottlebrush 91

Bouteloua 141

barbata 143

curtipendula 141

eriopoda 142

gracilis 131,143

hirsuta 142

Brachiario 157

ciliatissimo 157

extenso 157

platyphylla 157

Brachyelytrum 119 erectum 119

var. septentrionale 119

BRACT: a modified leaf. Glumes, lemmas, prophylls, and poleas are bracts. 5 Fig. 360

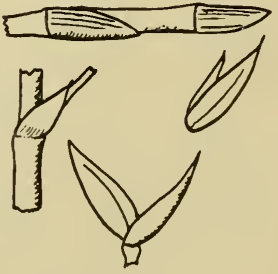

Figure 360

Bristly foxtail 151

Briza 45

media 45

minor 45 


\section{INDEX}

Bromus 59

anomalus 65

var. lanitipes 65

arvensis 64

brizaeformis 63

carinatus 60

catharticus 59

ciliatus 62

commutatus 65,67

inermis 61

japonicus 64,65

kalmii 66

latiglumis 63

mollis 66

pumpellianus 61

purgans 62

f. glabriflorus 62

racemosus 67,65

rigidus 69

rubens 67

secalinus 64,65

sterilis 68

tectorum 68

vulgaris 61

Brookgrass 32

Broomcorn millet 173

Broomsedge 181

Browntop 116

Browntop millet 171

Buchloe 16, 131 dactyloides 16, 131

Buffalo grass 131

Bullgrass 124

Burro grass 26

Bush muhly 125

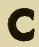

Colamagrostis 113 canadensis 114 inexpansa 114 rubescens 113

Colamovilfa 115 gigantea 115 longifolia 115

CALLUS: the hardened or sharpened lower end of a floret. 6 Fig. 361
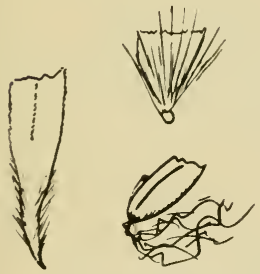

Figure 361

Canada bluegrass 75

Conada wild rye 94

Canary grass 144

Cone 15

Carpet grass 159

Cotabrosa 32

oquatica 32

Catchfly grass 146

Cenchrus 16, 149

pauciflorus 16,149

tribuloides 149

Cheat 64

Chess 64

Chewings fescue 73

Chlorideae 11, 19, 20, 21, 131

Chloris 139

gayana 140

petraeo 139

verticillata 141

virgata 140

Cinna 104

arundinacea 104 latifolia 104

CLEISTOGAMOUS: self-pollinated within unopened buds or florets. 6

Cleistogamous spikelets 28 , 99

Cleistogenes 99, 100

Cocklebur grass 129

Cogon grass 176

Coix 184 lacryma-jobi 184

Colorado grass 170

Cottontop 155

Crabgrass 158

Creeping bent 116

Creeping red fescue 73

Crested dogtail 26

Crested wheataross 88

Crinkle awn 180

Ctenium 138 oromaticum 138

CULM: the flowering stem of grasses. 3

Cultivated oats 99

Curly mesquite grass 130

Cut grass 146

Cynodon 135 dactylon 135

Cynosurus 26

cristatus 26

Cyperaceae 2

\section{D}

Dactylis 44

glomerata 44

Dactyloctenium 134

aegyptium 134

Dallis grass 161

Danthonia 99

californica 99

compressa 100

intermedia 99

spicato 100

Darnel 86

DECUMBENT: soid of stems which ore somewhat creeping at the base. 3

Fig. 362

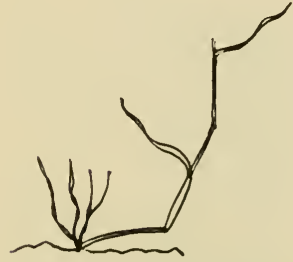

Figure 362
Deschampsio 96

coespitoso 96

flexuoso 96

Diarrheno 31

americana 31

Digitaria 157

filiformis 157

ischoemum 158

songuinalis 158

DIOECIOUS: having the staminate and pistillate flowers on separate plants.

Diplachne 133

DISARTICULATE: to break up at some definite point, determined by anatomy. 6 Fig. 363

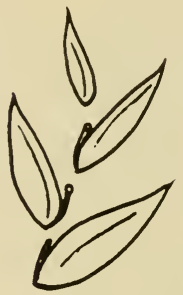

Figure 363

Disarticulation 6

Distichlis 17, 25 spicata 25 stricto 17,25

Dogtown grass 107

Dorsally compressed 7

Downy brome 68

Dune sandbur 149

E

Echinochloo 156

crusgalli 156

pungens 156

walteri 156

Eleusine 134 indica 134

Elymus 92

canadensis 94

cinereus 93

condensatus 93

riporius 94

triticoides 92

villosus 93

virginicus 94

Emmer 87

Enneapogon 23

desvauxii 23 
Eragrostis 32,33

beyrichii 35

capillaris 40

cilianensis 41

ciliaris 34

curvula 37,38

frankii 40

glomerata 34

hirsuta 38

hypnoides 33

intermedia 39

megastachya 41

multicaulis 42

oxylepis 35

pectinacea 42

peregrina 42

pilosa 43

poaeoides 41

reptans 33

secundiflora 35

sessilispica 35

spectabilis 36

trichodes 37,38

Ergot 86,161

Erianthus 177

alopecuroides 177

contortus 177

giganteus 177

ravennae 178

saccharoides 177

Eriochloa 155

contracta 155

Euchlaena 185

mexicana 185

Eulalia 176

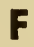

Fall Panicum 174

Fall witchgrass 163

False buffalo grass 131

Feather fingergrass 140

Festuca 70

arizonica 73

capillato 73

elatior 70

idahoensis 73,74

kingii 71

obtusa 71

occidentalis 73

octoflora 70

ovina 74

var. brachyphylla 74

paradoxa 71

rubra 73

thurberi 72

viridula 72

Festuceae 10, 22, 23

Festucoideoe 10

Field sandbur 149
FLORET: the unit of the Goatgrass 85 spikelet, consisting of a Goosegrass 134 flower and the lemma and Gramineae 1,2 palea which surround it. Grasses 2

5. Fig. 364 Green fescue 72

Green foxtail 153

Green sprangletop 133

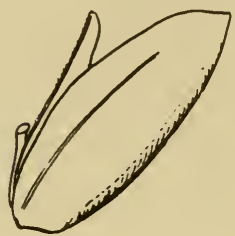

Figure 364

Flower clusters 4

Flufforass 29

Fluminea 46 festucaceo 46

Fountain grass 150

Foxtail barley 90

Foxtail millet 152

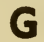

Galleta grass 130

Gama grass 184

Gardeners Garters 144

Gastridium 113

ventricosum 113

Giant dropseed 128

Giant foxtail 153

Giant reed 24

Giant wild rye 93

GLUME: an empty bract at the base of a spikelet. 5 Fig. 365

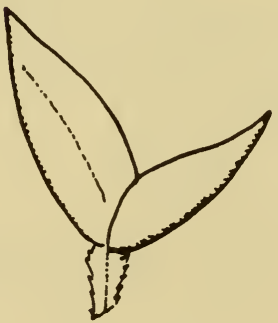

Figure 365

Glycerio 52

ocutiflora 52

borealis 53

canadensis 55

elata 56

fluitans 53

grandis 55

melicario 54

obtusa 54

pallida 57

var. fernaldii 57

pauciflora 57

septentrionalis 53

striato 56

cylindrica 176
Gymnopogon 139

ambiguus 139

H

Hackelochloa 178 granularis 178

Hair fescue 73

Hairgrass 96

Hairy grama 142

Hesperochloo 71 kingii 71

Heteropogon 179

contortus 179

melanocarpus 180

Hierochloe 145 odorato 145

Hilaria 130

belangeri 130, 131

jamesii 130

mutica 130

rigida 130

Holcus 19, 101

lanatus 19, 101

Holy grass 145

Hordeae 10, 21, 85

Hordeum 90

brachyantherum 91

jubatum 90,92

leporinum 9

pusillum 9

vulgare 90

Hydrochloa 147

carolinensis 147

Hystrix 91

patula 91

var. bigeloviana 91

Imperata 176

brevifolia 176

Indian corn 185

Indian grass 182

Indian ricegrass 108

Inflorescence 4

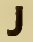

Japanese brome 64

Job's tears 184

Johnson grass 183

Juncaceae 2

Junegrass 95

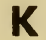

KEEL: a shorp fold, resembling the keel of a boat. 6

Kentucky bluegrass 78

Knotgrass 160

Koeleria 95

cristata 95 


\section{IN DEX}

Lacegrass 40

Laterally compressed 6

Leaves 4

Leersia 146

lenticularis 146

oryzoides 146

virginica 147

LEMMA: the outer bract of a floret, which encloses the flower. 5 Fig. 366

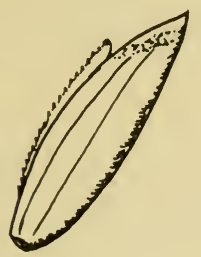

Figure 366

Leptochloa 132

dubia 133

fascicularis 133

filiformis 132

Leptoloma 163

cognatum 163

LIGULE: a collar-like projection at the base of a leaf blade, 4 Fig. 367

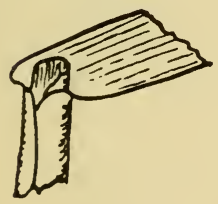

Figure 367

Little barley 91

Little bluestem 180

LODICULE: a small blisterlike body at the base of the flower, which forces the floret open at the time of blooming. 5 Fig. 368

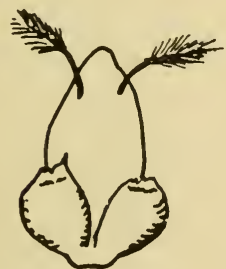

Figure 368
Lolium 86

perenne 86

var. italicum 86 temulentum 86

Lycurus 102 phleoides 102

\section{M}

Maiden cane 172

Maize 185

Manisurus 179 rugosa 179

Mat muhly 121

Meadow fescue 70

Meadow foxtail 103

Melica 47

bulbosa 51

fugax 51

imperfecta 51

mutica 48,49

nitens 49

porteri 48

var. laxa 48

smithii 49,68

spectabilis 50

stricta 47

subulata 50

MIDRIB: the conspicuous center "vein" of a leaf. 4

Milium 105 effusum 105

Miscanthus 176 sinensis 176

Monocotyledons 1

Mountain brome 60

Muhlenbergia 120

arenacea 121

asperifolia 121

cuspidata 124

emersleyi 124

frondosa 122

glomerato 122

mexicano 123

montana 123

porteri 125

racemosa 122

richardsonis 121

schreberi 120

sobolifera 122

squarrosa 121

sylvatica 123

torreyi 125

wrightii 124

Munroa 27, 131

squarrosa 27,131

Mutton grass 82

\section{N}

Natal grass 154

Needle and thread 110

Needlegrass 106

NERVE: one of the vascular bundles of a leaf or other plant structure, also called a vein. 4,6

New Zealand bent 116

Nimble Will 120

Nit grass 113

Nodding fescue 71

Nodding foxtail 152
NODE: the usually swollen joint of a stem, at which a leaf is attached. 3

Fig. 369

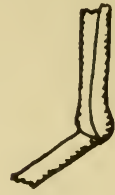

Figure 369

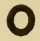

Oats 99

Oniongrass 50, 51

Orchard grass 44

Oryza 146

sativa 146

Oryzeae $11,18,146$

Oryzopsis 108

asperifolia 108

hymenoides 108

micrantha 109

miliocea 109

racemoso 108

OVARY: the swollen lower portion of the pistil, which contains the seed. Fig. 370

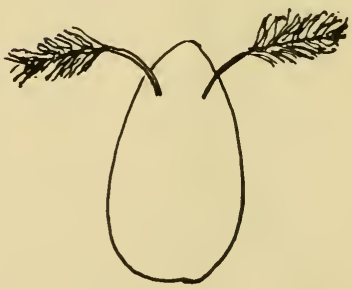

Figure 370

P

PALEA: the inner of the two bracts which enclose a grass flower. 5,6

Fig. 371

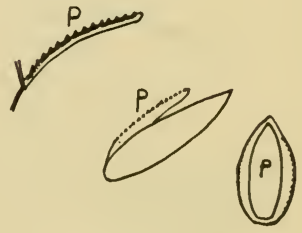

Figure 371 
Paniceoe 12, 19, 149

PANICLE: a much-branched inflorescence, bearing spikelets on pedicels. 4

Panicoideae 12, 149

Panicum 165

agrostoides 175

anceps 175

arizonicum 170

ashei 169

boscii 167

brachyanthum 170

capillare 173

clandestinum 167

columbianum 169, 166

condensum 175

depauperotum 165

dichotomiflorum 174

dichotomum 168

fasciculatum 171

var. reticulatum 171

hemitomon 172

implicatum 166

latifolium 167

lindheimeri 165

meridionale 169

microcarpon 168

miliaceum 173

obtusum 171

polyanthes 168

rhizomatum 175

scoparium 166

scribnerianum 167

sphaerocarpon 168

texanum 170

verrucosum 170

virgatum 174

Pappophorum 23 wrightii 23

Pappus grass 23

Paspolum 159

debile 160

dilatatum 161

dissectum 159

distichum 160

floridanum 162

laeve 162

var. circulare 162

pubescens 161

setaceum 160

urvillei 161

Peanut grass 164

Pearl millet 150

PEDICEL: the stalk of a single spikelet. 5

Fig. 372

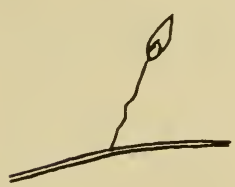

Figure 372

PEDUNCLE: the stalk of an inflorescence. 5

Pennisetum 20, 150

glaucum 150

ruppelii 150

setaceum 150
PETIOLE: a leaf stalk (ab-Puccinellia 58 sent in most grasses ex- a:roides 58 cept bamboos).

Phalarideae 11, 22, 144

Phalaris 144

orundinacea 144

canariensis 144

Phleum 112

olpinum 112

pratense 112

Phragmites 24

communis 24

Pine dropseed 126

Pinegrass 73, 113

Pinyon ricegrass 111

Piptochaetium 111

fimbriatum 111

Plains bluegrass 76

Plains foxtail 154

Poo 75

alsodes 80

annua 82

arachnifera 17, 77

arido 76

autumnalis 81

compressa 75

cusickii 83

cuspidata 77

epilis 84

fendleriano 82

glaucifolia 76

interior 79

macrantha 77

nervosa 76

nevadensis 83

palustris 79

pratensis 78

scabrella 81

sylvestris 80

trivialis 79

Polypogon 103

monspeliensis 103

Porcupine grass 109

Poverty ootgrass 100

Prairie cup grass 155

Prairie dropseed 127

Prince Edward Island bent 116

PROPHYLLUM: the membranous structure found between the main stem and the base of a branch. 3 Fig. 373

distans 58

fasciculata 58

nuttalliana 58

PULVINUS: a swelling at the bases of bronches of an inflorescence. 5

Purple lovegross 36

Purpletop 29

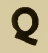

Quackgrass 88

Quaking grass 45

$\mathbf{R}$

Rabbitfoot grass 103

RACEME: an unbranched inflorescence, bearing spikelets on pedicels which are attached to the central axis. 5 Fig. 374

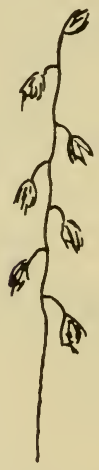

Figure 374

RACHILLA: the central stalk of a spikelet, which bears the florets. 5, Fig. 375

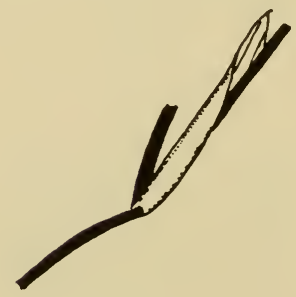

Figure 373

Proso millet 173

Pseudososo 15

japonica 15

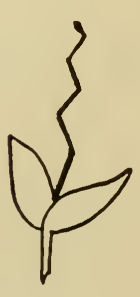

Figure 375 


\section{INDEX}

RACHIS: the central axis of Sedge Family 2 an inflorescence, which Sedges 2 bears branches or spike- SESSILE: seoted directly on lets. 5

Rattlesnake chess 63

kattlesnake manno 55

Ravenna grass 178

Red fescue 73

Red sprangletop 132

Redfieldio 28

flexuoso 28

Redtop 117

R.eed 24

Reed canary grass 144

Rescue grass 59

RHIZOME: a stem which grows beneoth the surface of the ground. 3, Fig. 376

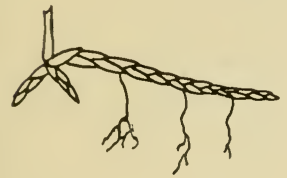

Figure 376

Rhode Island bent 116

Rhodes grass 140

Rhynchelytrum 154 roseum 154

Rice 146

Ringgrass 125

Rip-gut grass 69

Roots 3

Rough stalk bluegrass 79

Ruby grass 154

Rush Family 2

Rushes 2

Rye 86

Ryegrass 86

\section{S}

Sacaton 129

Saccharum 178 officinarum 178

Socciolepis 163 striata 163

Sack grass 163

St. Augustine grass 149

Salt gross 25

Salt-marsh grass 136

Sand bluestem 181

Sand dropseed 128

Sand lovegrass 37

Sand reedgrass 115

Satintail 176

Schedonnardus 136 paniculatus 136

Schizachne 46 purpurascens 46

Scholochloo 46 festucacea 46

Scleropogon 17,26 brevifolius 17,26

Scratchgrass $12 i^{26}$

Seo oots 43

Secale 86 cereale 86 the axis; lacking a pedi-

cel. 6, Fig. 377

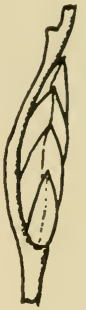

Figure 377

Setaria 151

foberii 152

geniculato 151

glauca 151

italico 152

lutescens 151

macrostachyo 154

magno 153

verticillata 151

viridis 153

SHEATH: the tubular, usually split portion of a grass leaf, which surrounds the stem. 4, Fig. 378

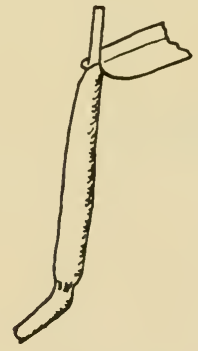

Figure 378

Sheep fescue 74

Side-oots grama 141

Silver beardgrass 182

Silver hairgrass 97

Silver plumegrass 177

Sitanion 92

hystrix 92

jubatum 92

Six-weeks fescue 70

Six-weeks gramo 143

Six-weeks grasses 70, 143

Skyline bluegrass 84
Sleepy grass 111

Slough grass 135, 137

Smilo grass 109

Smooth brome 61

Smooth crabgrass 158

Sorghastrum 182 nutans 182

Sorghum 183

holepense 183

sudanense 183

vulgare 183

Southern wild rice 148

Spartina 136

alterniflora 137

cynosuroides 137

gracilis 136

patens 136

pectinato 137

townsendii 137

Spelt 87

Sphenopholis 100

intermedia 100

nitida 100

obtusato 100

SPIKE: an unbranched inflorescence, with spikelets attached directly to the axis. The spikelets may be on one side or both sides of the rachis. 5, Fig. 379

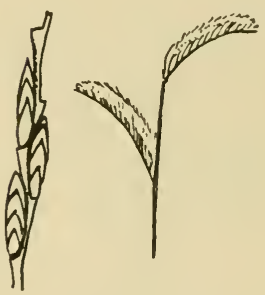

Figure 379

Spike fescue 71

Spike muhly 124

Spike redtop 118

Spike Trisetum 98

SPIKELET: the smollest branchlet of a grass inflorescence, typically consisting of glumes, rachilla, and florets. 5

Spikelets 5

Sporobolus 126

airoides 128

osper 127

clandestinus 127

cryptandrus 128

giganteus 128

heterolepis 127

mocer 127

neglectus 126

vaginaeflorus 126

wrightii 129

Squirreltail 92

STAMEN: the pollen-producing organ of a flower. 5

Stems 3

Stenotophrum 149

secundatum 149 


\section{INDEX}

STIGMA: the feathery appendages at the tip of the ovary, which receive pollen. 6, Fig. 380

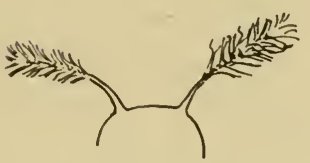

Figure 380

Stinkgrass 41

Stipa 109, 179, 180

comata 110

leucotricha 110

robusta 111

spartea 109

viridula 111

STOLON: a stem which creeps along the surface of the ground. 3, Fig. 381

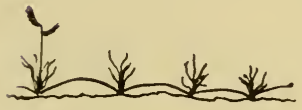

Figure 381

Sudan grass 183

Sugar cane 178

Sweet vernal grass 145

Switch grass 174

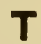

Tall oatgrass 96

Tangleheod 179

Teosinte 185

Texas bluegrass 77

Texas millet 170
Texas needlegrass 110

Ticklegrass 118

Timothy 112

Tobosa grass 130

Toothache grass 138

Trachypogon 180 secundus 180

Tragus 16, 129 beteronianus 16, 129

Trichachne 155 californica 155

Trichloris 138 blanchardiano 138 crinito 138 mendocina 138

Tricholaena 154 rosea 154

Tridens 2.2, 29

albescens 30

chapmani 29

elongatus 31

flovus 29

muticus 31

pilosus 30

pulchellus $2 \mathrm{c}$

Triodia 29

albescens 30

flava 29

mutica 31

pilosa 30

pulchella 29

Triplasis 28

americana 28

purpurea 28

Tripsaceae 13, 16, 17, 184

Tripsacum 184 dactyloides 184

Trisetum 97

interruptum 97

pennsylvanicum 97

spicatum 98 wolfii 98

Triticum 87

aestivum 87

Trivialis 79

Tumblegrass 136

\section{$\mathbf{U}$}

Uniola 43

latifolia 44

paniculata 43

\section{V}

Vasey grass 161

VEIN: one of the vascular bundles of a leaf or other plant structure, also called a nerve. 4,6

Velvet grass 101

Vine mesquite gross 171

Virginia wild rye 94

Vulpia 70

\section{W}

Woter grass 147

Wedgegrass 100

Weeping lovegrass 38

Western wheatgrass 87

Wheat 87

White grass 147

Wild chess 66

Wild oots 99

Wild Rice 148

Windmill grass 141

Wiregrass 106

Witch aross 173

Wolftail 102

Woodreed 104

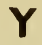

Yellow foxtail 151

\section{$\mathbf{Z}$}

Zawadke alkali grass 58

Zea 185

mays 185

Zizania 148

aquatica 148

Zizanieae 12, 17, 147

Zizaniopsis 148

miliacea 148

Zoysieae 11, 20, 129 





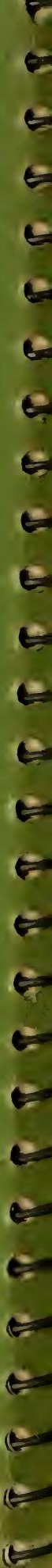

8

$\Leftrightarrow$

$E$

눙

3

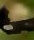

8

8

6

을

$\Leftrightarrow$

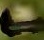

$\Leftrightarrow$

5

$F$

$\Leftrightarrow$

$E$ 